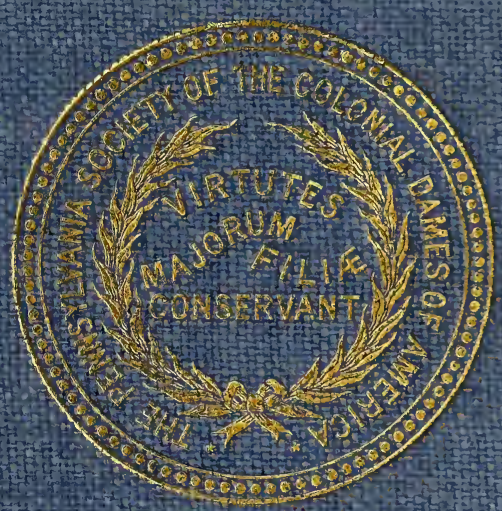



$60-$

veyx $\rightarrow$ 



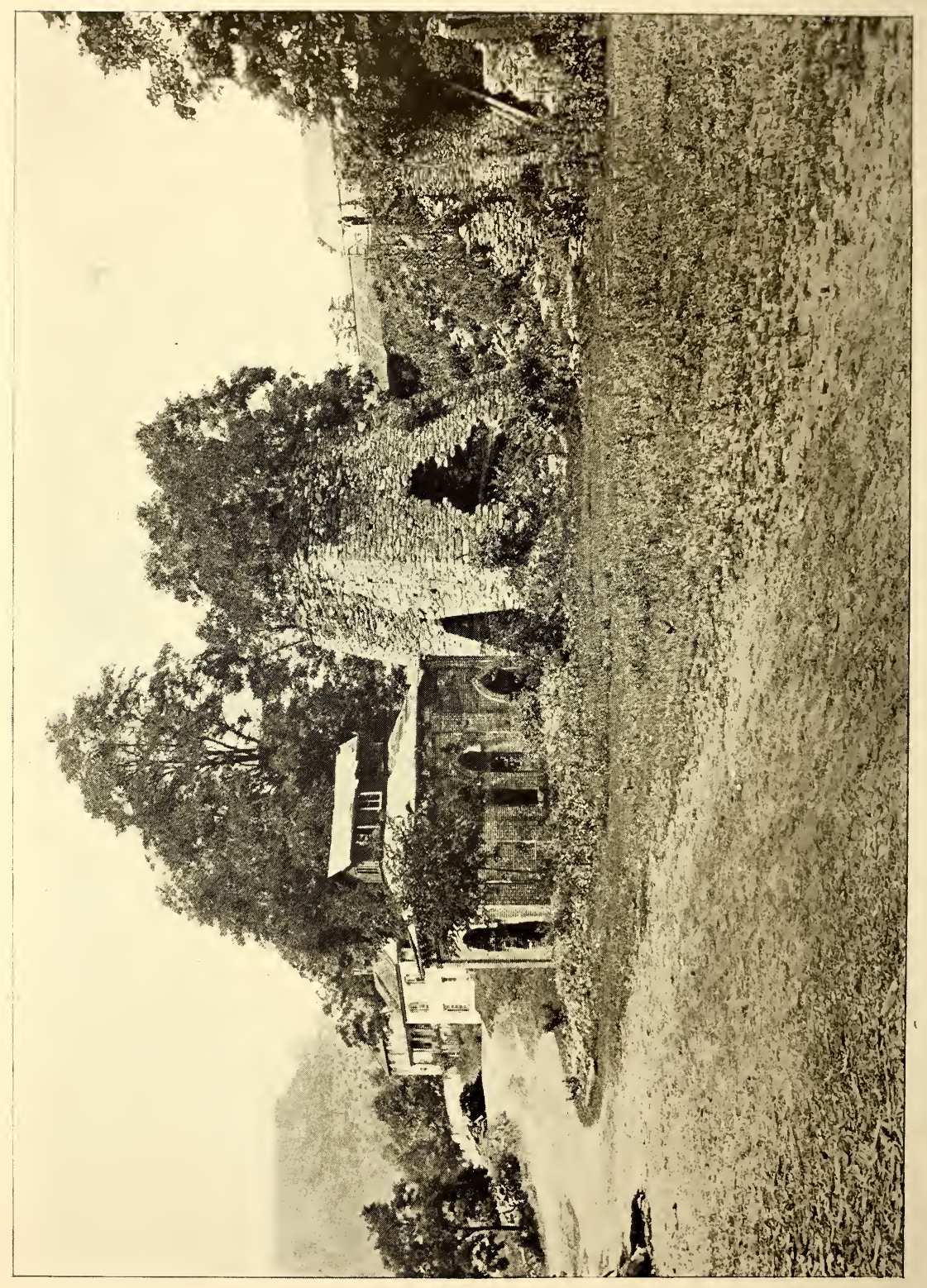

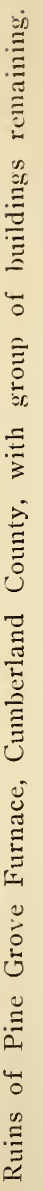


PUBLICATIONS OF THE PENNSYLVANIA SOCIETY

OF THE COLONIAL DAMES OF AMERICA-III

\section{Forges and Furnaces in the \\ Province of Pennsylvania}

PREPARED BY

THE COMMITTEE ON HISTORICAL RESEARCH

\section{JUL 231980}

PHILADELPHIA

Printed fOR the Society

I9I4 
Copyright, I9I4

By The Pennsylvania Society of the Colonial. Dames of America PRESS OF
THE NEW ERAPRNTING COMPANY
LANCASTER, PA. 
COMMITTEE ON HISTORICAL RESEARCH.

Mrs. James M. Longacre, Chairman, Mrs. William J. Rose, Mrs. Francis B. Gummere, Miss Anne Hollingsworth Wharton, Mrs. Thomas S. Kirkbride, Mrs. Joseph P. MUMFord, Miss Susan Carpenter Frazer, Mrs. Alfred Cope, Mrs. Edgar W. Baird, Mrs. Edward Browning Meigs, Mrs. Robert E. Brooke. 

THIS book, a tribute of the Pennsylvania Society to 1 "the days of old, the years of ancient time," is the labor of love of our own members. As far as possible we have gone to original sources for information and verification, and have consulted many living authorities, whose valuable counsel has been freely given us. We wish to express our indebtedness particularly to Mr. James $\mathrm{M}$. Swank, the Hon. S. W. Pennypacker, President of the Historical Society of Pennsylvania, Dr. John W. Jordan, the Hon. E. W. Biddle, Dr. Chas. F. Himes, Mr. H. C. Grittinger, Mr. B. F. Fackenthal, the Hon. W. U. Hensel, Mr. J. A. Anderson, Mr. W. M. Mervine, Miss Martha Bladen Clark, Mrs. A. Saunders Morris, Col. Henry D. Paxson, Mr. Thomas Eakins, Mr. P. Hollingsworth Morris, Mr. Ernest Spofford, Mr. B. F. Owen. 

"If you're off to Philadelphia this morning And wish to prove the truth of what I say I pledge my word you'll find

The pleasant land behind

Unaltered since Red Jacket rode that way.

"Still the pine woods scent the noon

Still the cat bird sings his tune

Still autumn sets the maple-forest blazing.

Still the grapevine through the dusk

Flings her soul-compelling musk

Still the fire flies in the corn make night amazing!

"They are there, there, there, with Earth immortal

(Citizens I give you friendly warning).

The things that truly last when men and times have passed,

They are all in Pennsylvania this morning."

Rudyard Kipling. 



\section{FORGES AND FURNACES IN THE PROVINCE OF PENNSYLVANIA}

Nearly two hundred years ago, in the early days of the "Holy Experiment," the wonderful natural resources of the province of Pennsylvania, - the great ore beds, the thickly wooded country giving endless charcoal, and the strong streams promising water power,-impelled many capable and hopeful men to attempt the making of iron. Besides capacity and hope, however, money was needed for even the smallest beginnings; and in going over the records one finds, in many cases, that a few years sufficed to bring the undertaking either to permanent grief or to a new owner. While this was the fate of some, others, faithful to the early visions of being great ironmasters, held on their way and realized their dreams; - handing down to our day their names, their industries, and their fortunes. We still have with us the descendants of Thomas Rutter, and Thomas Potts, and Anthony Morris; of James Logan, and Peter Grubb, and Robert Coleman; and of many others.

Of those who fell by the wayside, the "iron band of Circumstance" being too much for them, the most noted possibly is Henry William Stiegel;- and why should we doubt that the place he occupies in our tradition and history;--picturesque, brilliant, unfortunate,-may be to him some compensation if his shade ever returns for the yearly Giving of the Red Rose in his memory?

As far as it is possible, some account of each of these pioneers will be given in the sketches which follow, of the forges and furnaces started in Pennsylvania before 
I776. We must disclaim however any intention to touch on the scientific side of the making of iron; that is utterly beyond our scope: we shall be satisfied if we are able to give glimpses of the life on these great estates (for "great" many of them grew to be), and to put on record the names more or less important, of the founders of the early wealth of Pennsylvania.

Until I682, the year of Penn's arrival, the settlers on the Delaware, under the Swedes, the Dutch, and the Duke of York, seem to have made no effort to manufacture iron in any form. The energy of Penn changed all that. $\mathrm{He}$ wrote in 1683 of the existence of "mineral of iron and copper in various places." Having iron furnaces himself at Hawkhurst in England, he naturally wished to encourage the manufacture of iron in his own province. Although there is no record of the Proprietor's connection with any iron making in Pennsylvania, there are a few allusions to a mining venture of which he had great hope, which seem of sufficient interest to mention.

A contemporary English historian, John Oldmixon, gives some side lights on Penn's more practical and worldly outlook, of a kind not freely afforded us by his biographers, but which tally with much in his letters to his Secretary Logan, and others, when dealing with personal and business matters. Oldmixon visited the Colonies while Penn was here, and also made extensive journeyings in the West Indies. In speaking of the notable men who had welcomed him on his arrival he says, ${ }^{1}$ "Mr. Docwra and Dr. Cox were both so kind as to inform me fully of the Jerseys, and Mr. Pen did me the same favor for Pennsylvania. those three gentlemen doing me the Honour to admit me into their Friendship." "Mr. Pen," he continues, "was a very sanguine person: he was generous and free of his

${ }^{1}$ British Empire in America, II, London, 174r. 
Thoughts and Expressions, which were not always suffciently guarded." In speaking of the early settlements here he says, "Sir William, Mr. Pen's Father, had a Kinsman who was one of the first planters at New England, and it was from him doubtless that he had exact and particular Information of the Advantages that might be made of Lands and Settlements in this Continent of America; but young Mr. Pen having filled his head with Quakerisms did not for some years apply himself strenuously to solicit the promised Grant, till at last finding his friends the Quakers were harassed all over England by Spiritual Courts, he resolved to put himself at the head of as many of them as would go with him and remove to the Country of which he obtained the Grant" (in I68I). ${ }^{1}$ Dean Swift said of this many-sided Penn that he talked very agreeably and with great spirit. While dwelling on his gayer side, the comment of Friends in Reading Meeting might be recalled: that he was "facetious in conversation." $\mathrm{He}$ rarely made use of the terms "Thee" and "Thou," and as is well known he wore buckles and wigs; the latter from necessity, it is said, having early lost his hair. With much political acumen and experience he was not a skillful judge of character; hence arose many of his difficulties. A fortunate man in many respects, he was for years especially favored in the devotion of the Secretary of the Province, James Logan, who agreed and remonstrated with him, advised and obeyed him, in the most faithful and patient fashion.

Anxious and harried as Penn was in his later years by stress of political, financial, and family troubles, he seems, at this time, to have had a short period of confident expectation as to the relief that might come to him if mines of value were actually discovered in his Pennsylvania domin-

1 British Empire in America, II. 
ions. Rumors reached him in 1708 , only four years before his final breakdown from paralysis, that the King of the Shawnee Indians was quietly working mines for Mitchel, a "Swiss acquainted with mining" and others, including Governor Evans. His eager pleasure is shown in the following letter to Logan: "I am glad . . . that mines so rich are so certainly found, for that will clear the country and me of all other encumbrances, and enable me to reward those that have approved themselves faithful to me and my just interest. Clap somebody upon them, as servants for me, and by next opportunity send me some of the ore, to get it tried by some of the ablest separators here." And later he writes: "Pray go to the bottom with Colonel Evans about the mines, and what has become of Mitchel? Who are let in the secret where they are?"

To this Logan replies, in due time, that he is trying to get the desired information. It must be remembered that the path of the faithful Secretary was seldom other than thorny: constant watchfulness was needed as early as 1707 to circumvent the French in their efforts to undermine the allegiance of the Indians to their English neighbors, and trading among the Indians was not allowed except under special license. Despite prohibitions the Frenchmen crept in, as traders, miners, or colonists. ${ }^{1}$ A few of them, James Le Tort, for example, and Peter Bezalion (whose grave is in the Episcopal Churchyard at Compass, in Lancaster county; he died in I742, aged eighty years) were licensed and valuable traders; valued, that is, except when they seemed to swerve from their allegiance, in which case they were called to Philadelphia and given a taste of jail life. Mitchel and T. Grey are also mentioned in the Colonial Records as fellow workers.

Disappointment, his usual portion in his later years, was

${ }^{1}$ Lancaster County Indians, by H. Frank Eshleman, p. 173. 
again meted out to Penn: and he writes to Logan early in the next year: "Mitchel has been with me, and by him and T. Grey I learn the misunderstanding between the late Governor and thy self, if they say true, has cost me dear: for they assure me he and company may, and they believe do, make $£$ Ioo. if not twice told, weekly. The Indians chiefly discovered the mine and work it on the spot, and he told me the way of it. It is the King of the Shawnee Indians, and some few of his subjects that perform the business for him, viz., Colonel Evans."

Logan somewhat later writes of Evans, "That story of his getting, by the mines, I believe to be very fiction. Evans has been very free with me upon that head (mines). There has been none opened, and I fear Mitchel has tricked us all,-he has gone over to England with an intention we believe of putting his countrymen, the Swiss, upon pur chasing from the Queen a tract beyond the Potomac, where, he thinks, they lie. It will therefore nearly concern thee to have an eye to all his motions. He is subtile and scarce to be trusted."'

These debatable mines may possibly have been the copper mines on Mine Ridge, a few miles south of Lancaster, near the Philadelphia Pike, where, "in I 843 the remains of an ancient shaft were visible. They were supposed to have been opened by French adventurers or persons from Maryland, about the time of Penn."2 An early mention of iron in the Province is in a "Description of Pennsylvania" by courtesy called "rhymed," written in 1692 by Richard Frame, and published by Bradford:
"A certain place here is where some begun To try some mettle and have made it run, Wherein was iron absolutely found At once was known about some forty pound."

1 Logan and Penn Correspondence, Vol. II.

2 Day's Historical Collections, p. 388. 
But just where this "mettle" was found he does not say. Although we avoid entirely, and that for the best of reasons, the scientific and technical side of iron making, it seems advisable to give, as concisely as possible, the primitive processes of the early forges and furnaces and the usual method of charcoal burning.

Early bloomaries in Pennsylvania were very like the Catalan forge or bloomary which originated in Catalonia, Spain, about the tenth century. They were not unlike a large blacksmith fire with a deep fire pot, in which the blast was introduced at the side instead of the bottom of the fire, and while yielding but a small output a day they were used on account of the small expense and labor involved in their erection. ${ }^{1}$

In the fires of the forges pig iron was converted into blooms which were usually round pieces of metal, about a foot long. The word bloomary was often used to describe a forge. This was because the product derived from the heated ore was obtained in the form of a lump or bloom of malleable iron. The word is derived from the AngloSaxon bloma, a lump. The product of the early forges was blooms and hammered iron in the shape of flat or square bars; these were shaped into vessels by blacksmiths and skilled artisans, who made a specialty of that class of work.

As a rule the old furnaces were built into the side of a hill, in order that the ore, limestone, and charcoal could be filled from the upper level into the stack. Built upon one general principle, the charcoal furnaces varied materially in size and appearance: "The interior of the furnace-stack was lined with a wall of fire brick, or else with fine-grained white sandstone, both of which were well adapted to resist the extraordinary heat to which it was

1 Cornwall Furnace and Ore Banks, by H. C. Grittinger. 
exposed. The lining was constructed a few inches from the main stack, the space between being filled with fragments of stone, sand, and occasionally coarse mortar. This served to protect the stack from the decomposing effect of heat. The furnace stack was, moreover, secured from expansion by strong iron girders embedded in it. The quantity of material filled in the top of the furnace stack was measured and called a charge. There were two charges or heats in the twenty-four hours.

The iron, melted in the furnace and run into "pigs" in the sand bed was not fit for other than casting use until it had been re-heated, puddled in a forge, and hammered into blooms. Puddling meant stirring and turning it with long iron bars in a small oven. In this way certain impurities were eliminated.

Two and one-half tons of ore, and I 80 bushels of charcoal produced about one ton of metal. The output of iron was about 28 tons a week, as against the 75 to 600 tons $a$ day produced by the modern furnaces. The limestone introduced was for fluxing or eliminating impurities, and the quantity used depended on the richness or metallic content of the ore. "Before using the ore it was washed by a big water wheel attached to a long lateral shaft which had heavy iron teeth running around it spirally and which revolved in a trough. The teeth stirred the ore in the water and finally threw it out in a pile from which it was gathered up in a cart. Lumps of ore that were too large to wash were purified and reduced by burning. They were stacked in the oven, charcoal filled between, and the huge pieces heated enough to break them." 1 Besides the ordinary furnacemen, cast boys, miners, and colliers, there were two keepers who took turns of twelve hours each to watch the furnace, a master miner, a chief collier, and a manager.

1 Pictorial Sketch Book of Pennsylvania, by Eli Bowen. 
Charcoal burning required both skill and patience. The process was intricate, depending for success on the state of the weather as well as on the watchfulness of the colliers. Necessarily there was great difference in the value of wood for making charcoal; the more compact and fine-grained it was the better coal it yielded, chiefly because of its containing less water and sap. Tough oak, therefore, was worth more than pine. "The trees were felled, and trimmed, and cut into lengths four feet long, and ranked in cords, by the wood choppers, who were paid so much a cord. They were followed by the colliers, who stacked the wood in a conical shape, standing the sticks on end. The cones at the base were about 25 feet in diameter, and up through the middle the sticks were put sufficiently far apart to form a chimney. After the wood was thus carefully arranged, brush wood and loose earth were thrown over the pile, so as to smother the flame, and prevent it bursting out from the mass of wood. For the purpose of attracting the fire all around the wood, holes were made in the sides to create draft through which the watery elements of the wood were expelled, by the heat of the hydrogen, oxygen, and carbon, which was, in turn, held in check by the exclusion of atmospheric air. Were the air allowed to circulate the entire mass of wood would be reduced to ashes. The burning lasted two or three days and nights, according to the nature of the wood,-and the success attending the operation."

Nearly all Colonial Furnaces cast stoves, and "hollow ware,"-commonly called pots and kettles. Of the decorations of these early stoves we cannot do better than quote Mr. Henry C. Mercer, an authority on the subject. He speaks of "the existence of plates of cast iron about two feet square, elaborately decorated with Biblical scenes, hearts, tulips, mottoes, and Scriptural quotations," which 
within the last twenty-five years have been rescued from scrap heaps, or "found as pavings for fireplaces, smoke houses, and bake ovens, or as the sluices of dams and the bridges of gutters." 1 The most valued plates found now are those of the five-plate jamb stove, or wall warming stove. "Made of five plates, sometimes without, sometimes with a sheet iron pipe, and sometimes connecting its smoke egress with an adjoining chimney through the wall brick end, it was cast at the old furnaces in Pennsylvania from the year I74I or earlier until about the year I760. Built with an open end against a wall through which its fuel was introduced from outside the room into which the stove protruded, it is to this wall box that most of the important decorated plates pertain." 2 These stove plates were evidently intended, as the tiles of the times were, to instill moral lessons, and, with the accompanying texts or mottoes, they undoubtedly served as object-primers for young intelligences.

Carrying their moulds from furnace to furnace, the German workmen wrought well: Many of their designs are imaginative and fine, if primitive, and the elastic and phonetic spelling on the plates is more than interesting; to decipher it is an art. The names of the German peasant artists have almost entirely perished; the gathered-up remnants, "iron heirlooms," show indeed a "leaven of art" in even the early household necessities of the Province.

Firebacks as well as stoves were made at an early date. These were placed at the back of the open fireplaces, to protect the bricks or mortar; - often there were side pieces as well, forming a fireplace lining. Illustrations of these

1 The Decorated Stove Plates of the Pennsylvania Germans, by $\mathrm{H}$. C. Mercer.

2 The Decorated Stove Plates of the Pennsylvania Germans, by $\mathrm{H}$. C. Mercer. 
and the stove plates will be given in connection with the furnaces where they were made, as far as we have been able to procure them. The process of moulding firebacks is interesting. The patterns were made in wood, and then pressed into sand which had been wet and pounded, to make it hard and unyielding enough to retain the impression of the wooden pattern, which was then carefully removed, and the melted iron allowed to flow into the impression thus made.

It may be well to begin our chronicles of the early iron works and their owners, with a quotation from J. Leander Bishop's "History of American Manufactures": "There are," he says, "few reliable statistics either of the number or product of iron works in any of the States in the eighteenth century." With these chastening words perpetually in mind, we go on, having in view two objects; the first, to be accurate as far as possible within our narrow limits; the second, to bring together, in fairly chronological order, some of the overlooked and forgotten details of early provincial existence, in the great State of which we are so justly proud. 
Philadelphia County, Later Berks.

The first successful attempt to establish iron works in Pennsylvania was that of Thomas Rutter, an English Quaker, who about I716 built a bloomary forge called Pool on Manatawny Creek, near Pottstown. Jonathan Dickinson writing in $\mathrm{I} 7 \mathrm{I} 7$ says, "This last summer one Thomas Rutter, a smith, who lives not far from Germantown, hath removed further up in the country and of his own strength hath set about making iron. Such it proves to be as is highly set by, by all the smiths here, who say that the best of Sweeds' iron doth not exceed it, and we have heard of others that are going on with the iron works. It is supposed there is stone (ore) sufficient for ages to come-and in all likelihood hemp and iron may be improved and transported home-. . . if not discouraged."

["American iron was sent to England in $17 \mathrm{I} 7$ and so much jealousy was excited by it in the mother-country that in 1719 a bill was introduced into Parliament to prevent the erection of rolling and slitting mills here; it was then rejected, but in $175^{\circ}$ such an act was finally passed; the exportation of pig metal to England free of duties was however, allowed."']

The original patent of William Penn to Thomas Rutter, of three hundred acres in Manatawny, issued in I 7 14-1 5 is still in the possession of a descendant. Two Pool Forges existed here, within a few miles of each other, for a short time. The authorities differ as to their dates and

1 Memorial of Thomas Potts, Jr., p. 26. 
precedence, and it seems probable that one simply succeeded the other, under the same owners. Situated about three miles above Pottstown, on the Manatawny, this bloomary forge was probably of the most primitive description, iron being made directly from the ore, as in an ancient Catalan forge.

In a list of passengers from London to Barbadoes in 1635, is the name of Thomas Rutter aged 22. ${ }^{1}$ Whether this Rutter is in any way related to the first ironmaster of the same name is dubious. The marriage of Thomas Rutter and Rebecca Staples took place in Friends' Meeting at Pennsbury, roth month, IIth, I685. ${ }^{2}$ On Holmes's map printed in Penn's time Thomas Rutter is mentioned as the owner of a tract of land bordering on Germantown, opposite Cresheim Creek, adjoining that of Thomas Masters. The place was called Bristol township, and is not far from Milltown, now Abington. Rutter and his wife became members of Abington meeting in 1685 . He was a Public Friend and an active member there until the schism among the Quakers, led by George Keith in I691. At that date he subscribed his name, with sixty-nine others, to the paper issued at Burlington in defence of Keith: a document not sufficiently well known. Rutter was baptized in I69 I by the Rev. Thomas Killingworth, and as he was already a preacher, he now set forth the doctrines of Keith, who taught that Christ the external Word, and the visible sacraments $\mathrm{He}$ commanded, were of higher value than the "inward light." Rutter organized several societies of this persuasion, among them being one at Lower Dublin in 1697 in the house of Abraham Pratt, which, after vicissitudes, seems to have developed into Trinity

1 John Camden Hotten, The Original Lists of Persons of Quality, Emigrants, Religious Exiles, etc., 1600-1700.

2 Records of Middletown Monthly Meeting, Bucks County. 
Church, Oxford, one of our most venerated churches, which possesses a chalice of silver presented by Queen Anne. Evidently a man of general interests, Rutter succeeded Pastorius in 1705-6 as Bailiff of Germantown.

In 17 I 7 he removed "up the Schuylkill" and was for years active in every phase of iron making as then understood.

When Rutter and Nutt settled on the Manatawny and French Creeks, they were in the midst of the Delaware or Lenni Lenape Indians: the "original people." In dealing with them, Penn, Pastorius, Rutter and Nutt had been friendly and earned their good will. William Penn's estimate of the Indian character, as he found it, is so fine, even if rose colored, that part of it must be quoted here. Writing to the Society of Free Traders, he says: "In liberality they excel; nothing is too good for their friend; give them a fine gun, coat, or anything, and it may pass twenty hands before it sticks. Light of heart, strong affections, but soon spent. The most merry creatures that live: feast and dance perpetually; they never have much, nor want much: wealth circulateth like the blood. None shall want what another hath, yet exact observers of property. Some Kings have sold, others presented me with several parcels of land; the pay or presents I made them were not hoarded by the particular owners. . . . They care for little because they want but little; and the reason is, a little contents them. In this they are sufficiently revenged on us; if they are ignorant of our pleasures, they are also free from our pains. They are not disquieted with bills of lading or exchange, nor perplexed with chancery suits or exchequer reckonings. We sweat and toil to live; their pleasure feeds them, I mean their hunting, fishing and fowling, and this table is spread everywhere. They eat twice a day, morning and evening, 
their seats and table are the ground. Since the Europeans came into these parts, they are grown great lovers of strong liquors, rum especially; and for it exchange the richest of their skins and furs. If they are heated with liquors, they are restless, till they have had enough to sleep; that is their cry,-Some more and I will go to sleep. But when drunk they are one of the most wretched spectacles in the world."

After the noted attack on Pool Forge in May, I728, by unfriendly Indians, when they were repulsed with small loss, by the workmen, there was a call sent out by Governor Gordon, to Sassoonan, the King of the Delawares, and the other chiefs, to a council or treaty at Philadelphia; presents were prepared for them, and they were hospitably entertained during their stay. At the first meeting, in the Court House, many Indians, Government officials, inhabitants and interpreters being present the Governor made a high flown and conciliatory speech, gave presents of blankets (Strouds, a kind of blanket made at Stroudwater ${ }^{4}$ in England), shirts, powder, lead, knives, scissors, - and finished by giving to the relations of the deceased Indians "these six handkerchiefs to wipe away their tears"! Another meeting was held the next day, but the excitement was so great that the Court House was too small, and they adjourned to the great Meeting House, a vast audience filling the house and all its galleries. Sassoonan, on being called to speak, asked his friend Thomas Rutter, Sr., "to sitt near him," and spoke warmly of what he would do to clear the path between the place where he lived and this town, he would "cutt up every bush and grub that may stand in the way." As applied to

1 "A town long famous for its woolens, and supposed to owe much of its prosperity to the peculiar qualities of the stream called Stroudwater, which is admirably adapted for dyeing scarlet." Lewis, Topographical Dictionary of England. 


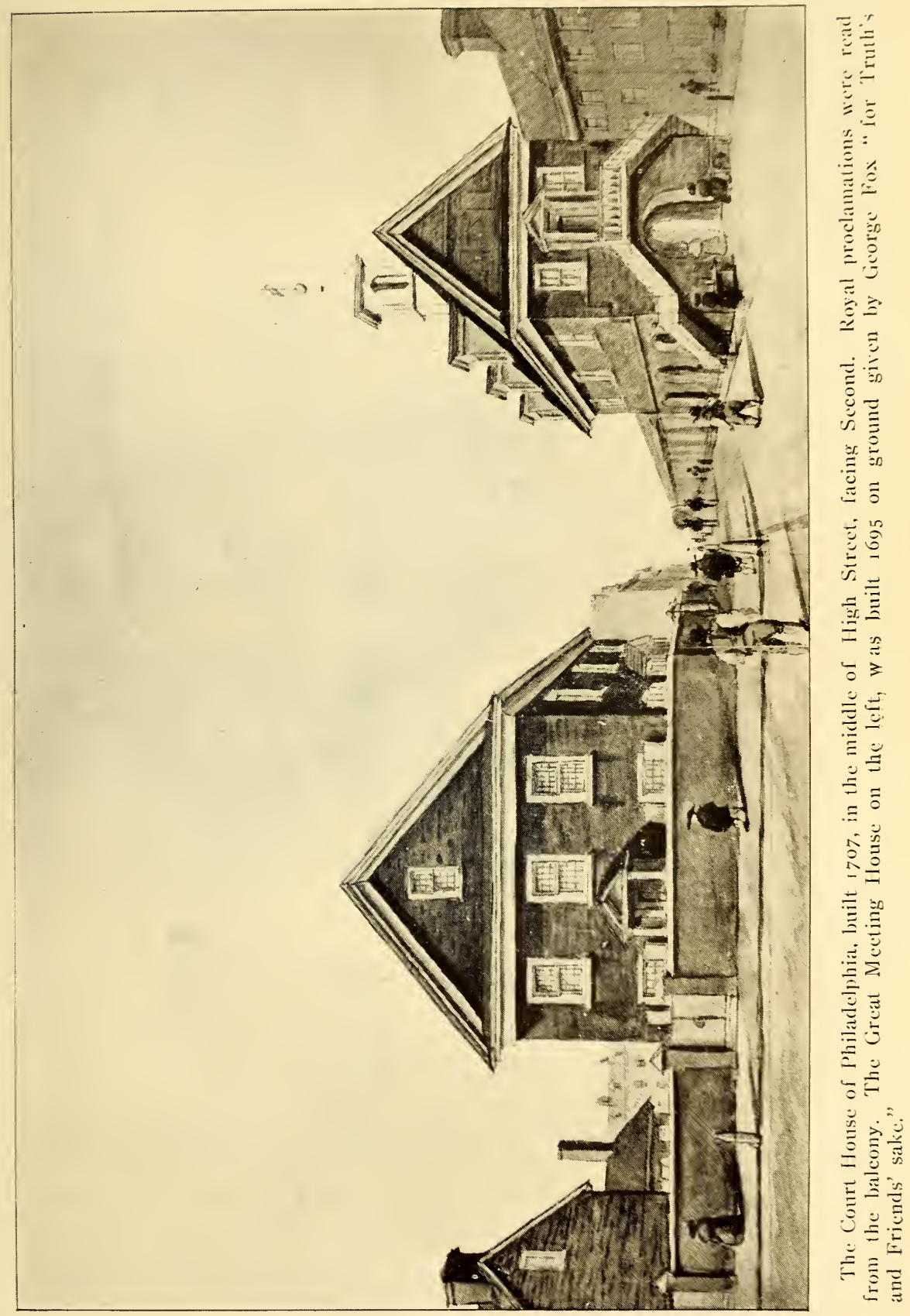





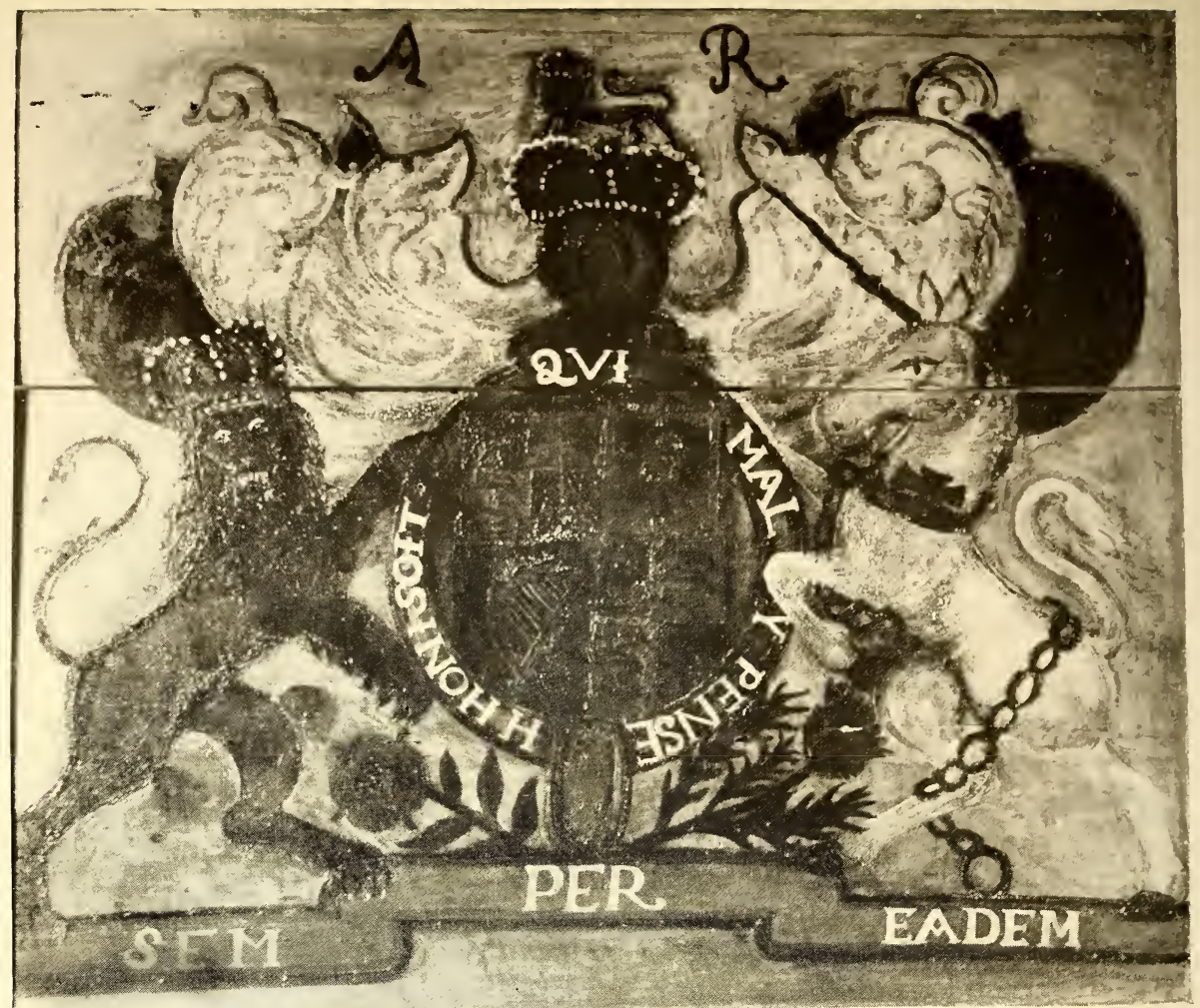

The Arms of Great Britain, painted on the panel in the Court House, behind the Judge's chair, 1707. Presented to the Historical Society of Pennsylvania when the Court House was taken down, 1837 .

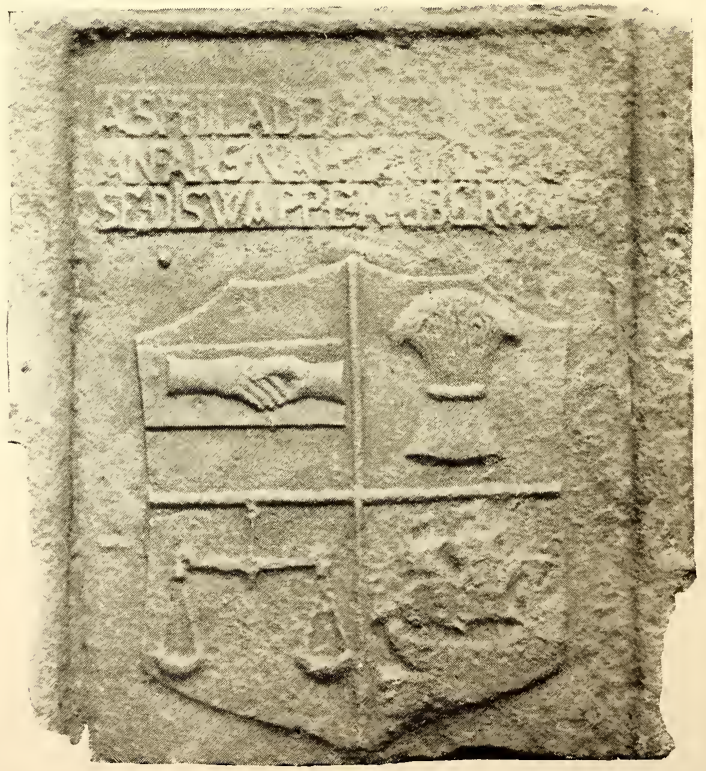

Stoveplate from old house, Chestnut Hill. The Seal of the City of Philadelphia. 
Rutter, this language seems to show his standing with neighboring Red men.

Besides the first forges, Thomas Rutter with others erected the first blast furnace, Colebrookdale, in the province. The original owners of Pool Forge and Colebrookdale Furnace were almost identical.

In I73I Pool Forge was owned by

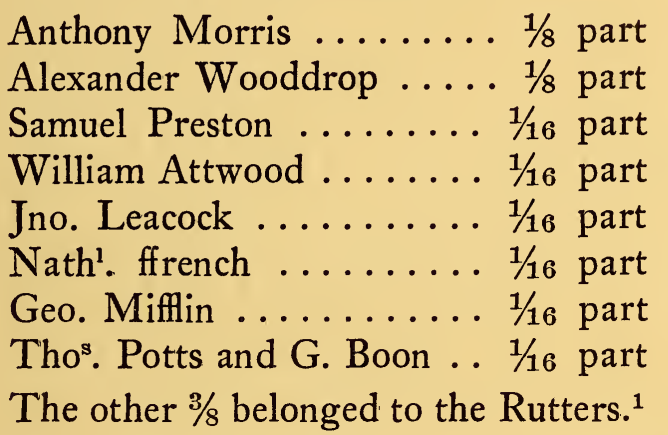

This man of many interests and enterprises did not live out his allotted years. The Pennsylvania Gazette, Philadelphia, March I3, I 729-30, has this entry: "On Sunday night last died here Thomas Rutter senior. He was the first that erected an iron work in Pennsylvania." At this date he was probably a little over sixty. Among the great names in our early iron industry, those of Rutter and Potts stand preëminent; their descendants have intermarried for six generations, during a period of one hundred and forty years. The list of forges and furnaces on the Manatawny and its branches, owned by the families of Rutter and Potts, before the Revolution, is most imposing. It includes Mount Pleasant Furnace and Forge, Spring Forge, Colebrookdale Furnace and Forge, Amity Forge, Rutter's Forge, Pool Forges, Pine Forge, Little Pine Forge and McCall's Forge. ${ }^{2}$

1 Memorial of Thomas Potts, Jr., p. 26.

Augusta $M$. Longacre.

2 Memorial of Thomas Potts, Jr., by Mrs. James. 


\section{Chester County.}

The beginnings of this noted forge on French Creek are somewhat misty. Evidently the earliest venture of Samuel Nutt, ${ }^{1}$ it was a Catalan forge, and dates from 17 I 8 or I719. By 1724, the iron made there was in demand.

Just when William Branson became a partner with Samuel Nutt is uncertain, but it was before 1728 , for there is, in an early newspaper, the offer of a reward of forty shillings, under their joint names, on March $29^{\text {th }}$ of that year, for one Richard Snaggs, who the Weekly Mercury of Philadelphia stated had deserted from the works on French Creek. The following winter, Nutt at the ironworks, and Branson at Philadelphia, offer the same sum for the recovery of John Bartam, a tailor, and Nathaniel Ford, who both ran away from the works. ${ }^{2}$

In the oldest Coventry Ledger extant, there are entries:

"Sept. 9, I727-To William Branson" etc His name occurs frequently.

"March 7, I727.

To bringing up a Cag of Rum by Anne Robert's Cart6d"

"March 27, I728. To the weaving of I I yds and I/2 Stuff by John Hibbert, omitted last reckoning,"

"Nov. 27, I729. By a Bridal for the Mrs."

"To one qt. malossos for Indian Daniel taking up your pocket book."

1 For Samuel Nutt, see Reading Furnace.

2 Futhey and Cope, Chester County, 344 . 
The keeper at the works was paid twenty shillings per week. An ore bed was discovered at Coventry in the early days, by an Indian. The reward, which was given to his daughter, was an iron pot, of the value of two shillings. ${ }^{1}$

There was an agreement, March 15, 1736, between Samuel Nutt and William Branson of the first part, and John Potts, of the second, in which the latter agrees to carry on a furnace called "Redding" recently built near Coventry, for the two former, who are "joint owners." William Branson had taken out warrants for additional land in I733. Some of this property adjoined that of Samuel Nutt, which may have been a reason, both for their partnership and for the disagreement which was being adjusted at the time of Samuel Nutt's death. In connection with the surveys, a correspondent writes to the surveyor, November 26, I 735 : "I have not seen Samuel Nutt since I received thy letter, which informs me of his returns being sent up. I hope that Wm. Branson's are also sent, that thereby the long-depending affair between them may be at length settled.", A man of enterprise, Branson, on the dissolution of partnership with the heirs of Samuel Nutt in 1739 , is said to have taken Reading Furnace as his share; and a little later, in 1742 , he became the owner of Windsor in Caernarvon township, and built a forge and the mansion. ${ }^{3}$ He was also the pioneer in steel, being the owner in 1737 , of the Vincent Steel Works on French Creek in Chester county. Just when Branson's steel furnace was started in Philadelphia is not certain, but it is said to have been "near where Thomas Penn first lived on Upper Chestnut street." The other one, Stephen Paschal's, was built in 1747 , and stood on a lot at the northwest cor-

${ }^{1}$ Book B. Ledger, Coventry, in collection of the Hon. S. W. Pennypacker.

2 Pott Memorial.

${ }^{3}$ See Windsor Forges. 
ner of Eighth and Walnut Streets. To complete the list of steel works in Pennsylvania at that time, we must mention a plating forge with tilt hammer in Byberry, Philadelphia county, owned by John Hall, who was a grandson of Thomas Rutter, son of Joseph and Rebecca Rutter Hall. Of the Vincent works, Acrelius says in 1756: "At Branz's works there is a steel furnace, built with a draught hole and called an 'air oven.' In this, iron bars are set at a distance of an inch apart. Between them are scattered horn, coal dust, ashes, etc. The iron bars are thus covered with blisters and this is called 'blister steel.' It serves as the best steel to put upon edge tools."1

William Branson was the son of Nathaniel Branson, of the parish of Soning, in Berkshire, England. Nathaniel Branson had purchased of William Penn twelve hundred and fifty acres in Pennsylvania, but he never came out to claim his tract. By deed of August 28, I707, this tract was conveyed to his son, William Branson, who the next year became a passenger on the Golden Lion and who took up his property by two separate warrants. For many years he lived in Philadelphia, occupying a house on the east side of Second street. His four daughters became the wives of well-known Pennsylvanians: Samuel Flower, Bernhard Van Leer, Lynford Lardner, and Richard Hockley. He died in I760. It is so difficult to obtain any clear information as to the ownership of the Coventry Iron Works from I 740 on, that one may be pardoned for a final impression that "Anna Nutt and Co.," were large owners; they are mentioned in a petition, I74I, as "owners of ironworks at Coventry and Warwick" and Mrs. James tells us that Mrs. Robert Grace bought back part of the Coventry estate. Thomas Potts (I735-I785) married Anna Nutt at Coventry in 1757, and established himself

1 Iron Making in Pennsylvania, Swank, p. 23. 


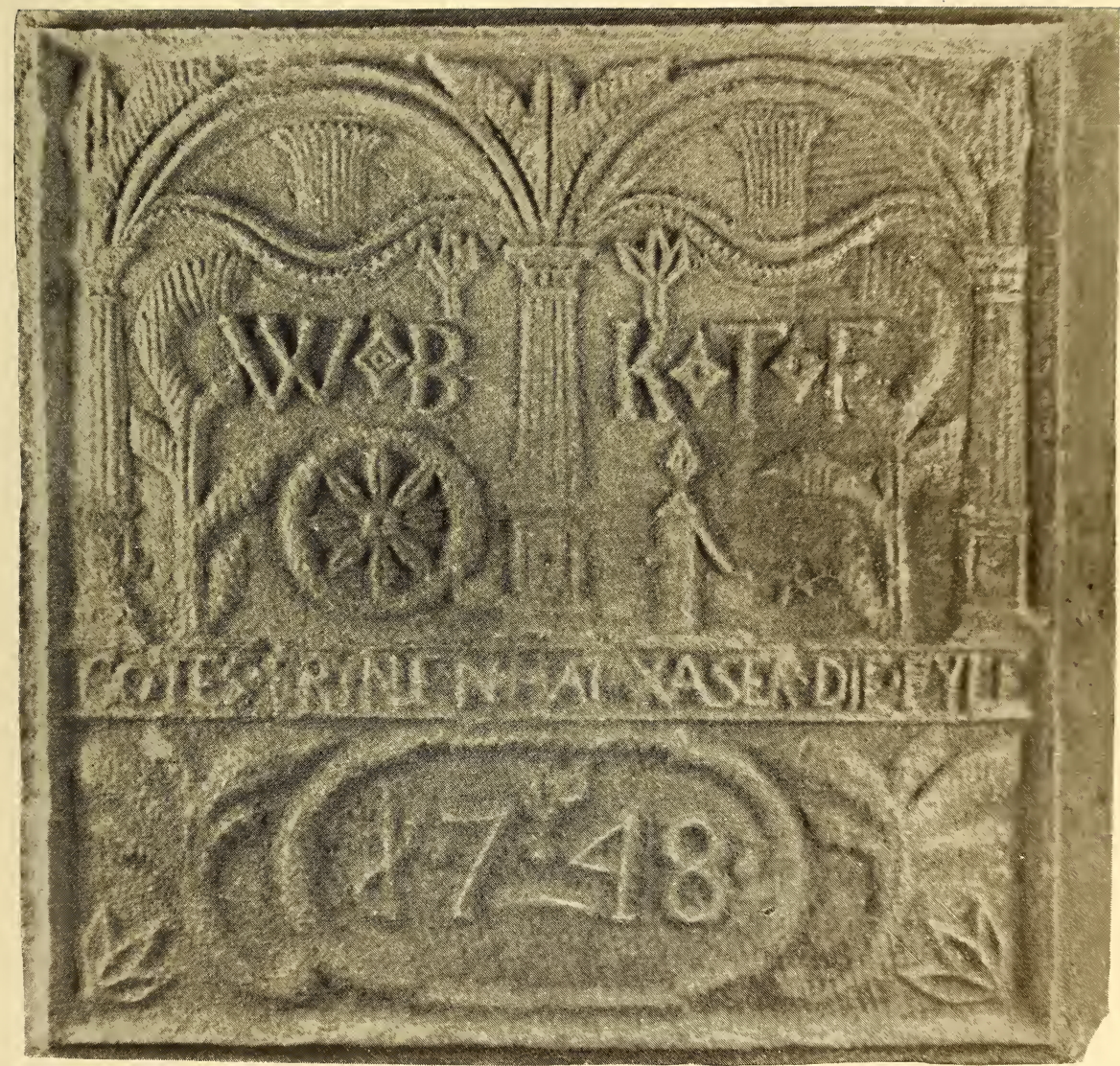

Stoveplate supposed to have been cast at Coventry. W. B. = William Branson. K. T. F. = Coventry Furnace. Owned by Mr. A. J. Steinman, Lancaster. 

in business in Philadelphia, for the sale of iron, with his uncle, Thomas Yorke. By his marriage a share in the forges and furnaces of the two Samuel Nutts on French Creek came into his hands. In 1765 he bought from his wife's mother and her husband, Robert Grace, all their rights in Coventry. The winter house of Thomas Potts and his wife was in Front Street, Philadelphia, then a fashionable quarter of the city. He was one of the original members of the American Philosophical Society, was interested in the navigation of the Schuylkill and other large State interests, and a warm adherent of the patriotic side, on the breaking out of the trouble with the Mother country. He removed to Pottstown in 1768 , where Washington was frequently his guest at the Mansion. ${ }^{1}$ For years he was a member of Assembly. Mrs. Grace entertained officers of the Army at Coventry Hall, during their stay at Valley Forge.

1 See Pottsgrove Forge. 


\section{COLEBROOKDALE FURNACE.}

Philadelphia County, later, Berks.

Those enterprising colonists, Thomas Rutter and Thomas Potts, having demonstrated beyond a doubt that the early experiments at the mouth of the Manatawny could be developed into a great iron industry, went to Philadelphia to seek capital for investment in their new enterprise. The time had come when they could no longer work single handed. The expense of building a furnace in those early days was about five hundred pounds. To this must be added the wages of men employed, and the cost of horses, oxen and wagons to transport the wood and iron. An area of woodland two miles square was sufficient to feed the furnace, but this had to be cut and made into charcoal. Without capital it was impossible to venture farther. Accordingly we find that about 1720 , new furnaces were projected along the Manatawny, and one on Iron Stone Creek, a branch of the former. This was called Colebrookdale, and was managed by a company including Rutter and Potts and the Philadelphians Anthony Morris and James Lewis. The original lease is interesting:

"Lease Dated the $13^{\text {th }}$ day of January I 724 Between Thomas Rutter $\operatorname{sen}^{\mathrm{r}}$ of the $\mathrm{I}^{\text {st }}$ part, Tho $o^{\mathrm{s}}$ Rutter and John Rutter of the $2^{\text {nd }}$ part, and Evan Owen, Maurice Morris, James Lewis, Robert Griffith and Thomas Marke of the third part-

"For a certain tract of Land Scituate upon Ironstone River in Manatawny in the County of Philadelphia containing 100 acres, To hold from the date above, for, and 



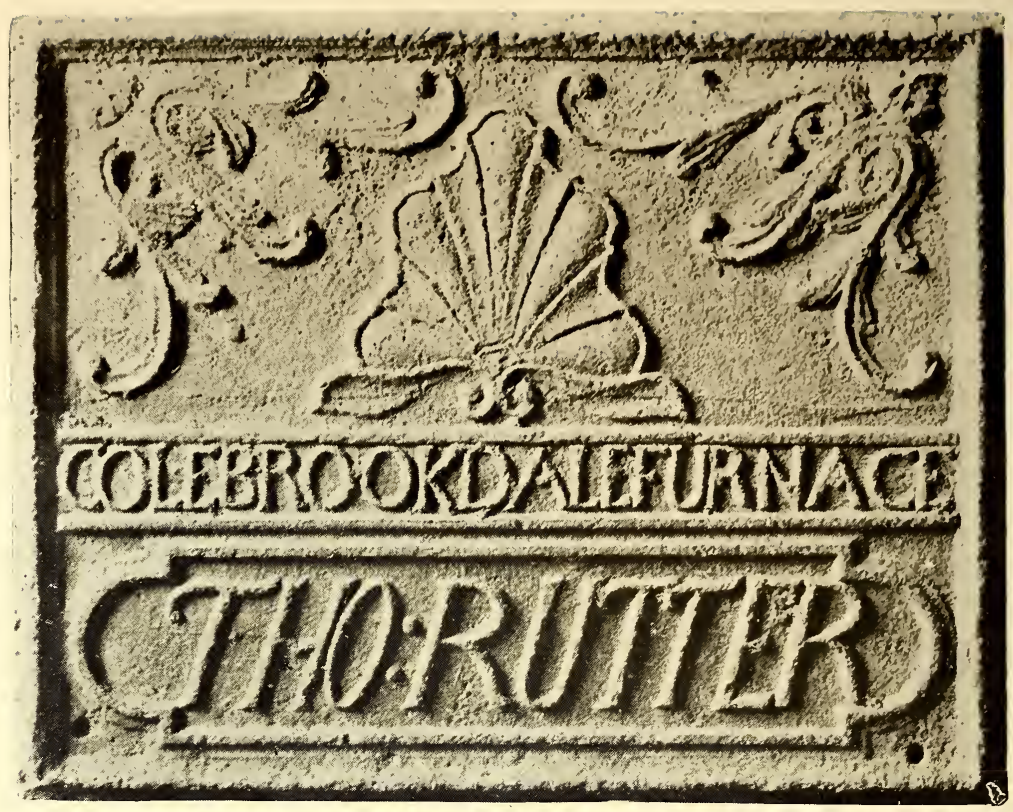

Stove plate cast at Colebrookdale Furnace. Owned by the Pennsylvania Museum in Memorial Hall.

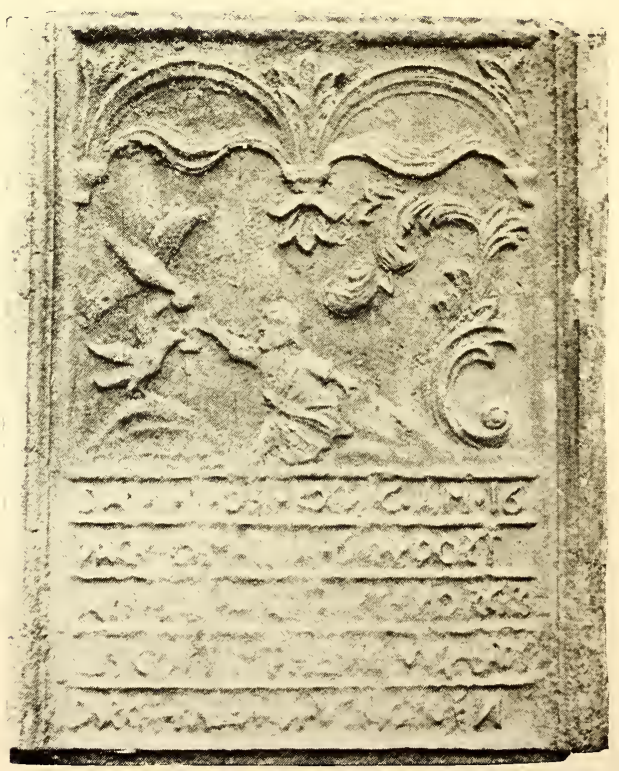

Elijah fed by ravens. Mate of the "Seal of Philadelphia" plate. 
during, and unto the full end and Term of 28 years from thence next ensuing and fully to be complete and endedunder the yearly rent of $\mathrm{L}_{30}$

"Also a deed of copartnership Between the said parties. The above Lease and Deed are Left in the hands of Charles Brockden to be kept indifferently between the parties"

2nd- "Thomas Potts sen ${ }^{\text {r }}$ Leased Colebrookdale Furnace $\mathrm{Jan}^{\mathrm{y}} \mathrm{I} 3^{\text {th }} \mathrm{I} 724$ at the rate of 48 Tonn piggs pr annum Each Tonn being valued at $\mathrm{L}_{5}$ - How much does the Rent amount to to the $13^{\text {th }}$ of January $174 \%$ being 24 years? "1

Swank's "History of Iron Making in Pennsylvania" says :

"The first furnace in England to cast pots and kettles and other hollow ware by the use of sand moulds, was Abraham Darby's Colebrookdale furnace in Shropshire, which he leased in I709. It was a small charcoal furnace and had been in existence for a century. He died in 1717. As he was a Contemporary pioneer in the iron business and a Friend or Quaker, as were most of the pioneer iron masters of Pennsylvania, it is easy to imagine that our colonists should have called their first furnace after the Colebrookdale furnace in Shropshire."

Famous as the first blast furnace in Pennsylvania, Colebrookdale had a long and prosperous career. It is mentioned in the Potts Memorial as still standing in 1785 though not in active operation. Though Thomas Rutter was the largest owner, the management from the first seems to have devolved on Thomas Potts. Thomas Rutter died in 1730 , and in the following years the company was reorganized by the persons whose names are here given and the proportion of shares held by each-

${ }^{1}$ Ledger of Colebrookdale Furnace, in collection of the Hon. S. W. Pennypacker. 


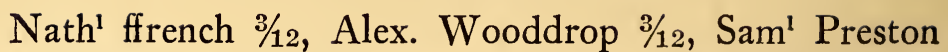
$1 / 12 \mathrm{~W}^{\mathrm{m}}$ Attwood $1 / 12$, Anth ${ }^{\circ}$ Morris $1 / 12$, Jno Leacock $1 / 12$, Geo Mifflin 1/12, T. Potts and G. Boon 1/12.

Mrs. James in the Potts Memorial copies the record of the cost of this rebuilding verbatim, the oldest document she is able to discover. It is written very handsomely on a folio sheet of paper, and is Thomas Potts's account with the company. Among other items we find

" $1 / 2$ gallon of Rum given to the workmen at the Limekiln, $1 / 2$ Gallon of Rum given to the workmen helping up with the girders,

To paid Timothy Miller for dyett, and customary allowance of Rum to the workmen when getting Inn Wall stones over the Schuylkill $£$ I-5-8.

An interesting item in the Company's minutes reads as follows-

"To the Persons in this minitt named, viz: Alex ${ }^{\mathrm{d}}$ Woodrupps, $\mathrm{W}^{\mathrm{m}}$ Attwood, $\mathrm{W}^{\mathrm{m}}$ Pyewell for Thomas Rutter, Anth. Morris, George Mifflin and Thos Potts, Being a majority of the Proprietors of Colbrook ffurnace Mett This 16 day of 6 mo 1736 .

"And on a Complaint $\mathrm{y}^{\mathrm{t}}$ some of the Own $\mathrm{n}^{\mathrm{rs}}$ of sd ffurnace were deficient in finding their proportion of wood for Coal for Carrying on the Blast of sd ffurnace According to articles of Agreement with Thomas Potts, Therefore made Inquiry Thereunto And find that there is a deficiency Chargable upon the Persons under named And it is now Agreed \& Concluded that they \& every of them Immediately find \& Provide the Quantity of Woodland annexed to their Names and $y^{t} y^{e}$ possess Thos. Potts with the wood thereon Standing for the use of the sd. Colebrook ffurnace the next ensuing Blast. On failure whereof 'tis Concluded \& Agreed $\mathrm{y}^{\mathrm{t}}$ the sd. Thomas Potts reserve \& Sell so much of their part \& share of the Pigg Iron Cast, or to be runn \& Cast as shall or may fully purchase or pay 
for their full Proportion of wood according to the und $\mathrm{d}^{\mathrm{r}}$ Estimate made the day and date above, viz-

Thomas Rutter, deceased to make good 55 acres woodland John Rutter deceased \& Thomas Potts 75 Ditto Samuel Preston

Edw'd ffream

Nath ${ }^{1}$ ffrench

Jno Leycock

Geo. Boom

75 Ditto

75 Do

75 Do

75 Do

$37^{1 / 2}$ Do

$4 \mathrm{I} 7^{1 / 2}$

Capt Attwood.

Taken from the Minutes of sd Comp'y and signed by us.

ANTH $^{\circ}$ MORRIS

ALEXANDER WOODROPP

William PyeWell

George Mifflin

$\mathrm{W}^{M}$ ATtwOOD

Thomas PotTs"

The amount of wood consumed by these charcoal furnaces was simply enormous. Some of them when in blast used from five to six thousand cords of wood annually, the product of about two hundred and forty acres of woodland. This was an advantage to the infant colony, since lands were thereby rapidly cleared which might be used for tillage.

No doubt Indians were employed to some extent at the forges since their names are found in lists of workmen-as "Indian John" and "Margalita": I728. Though Thomas Potts was connected with many of the furnaces in the Manatawny region, Colebrookdale was the scene of his greatest activities. He became possessed of great estates and built not far from the furnace a fine mansion, still standing, called Popodickon, from an Indian King, 
Popodick, who is buried under a magnificent chestnut tree about five hundred yards from the house. Tradition says the Ironstone Creek was originally called the Popodick. When in 1732 Benjamin Franklin established the Philadelphia Library Company Thomas Potts was one of the fifty subscribers to the project, thus indicating his interest in literary matters as well as in extending his material possessions. Before his death in $175^{2}$ in the seventy second year of his age, he saw all his sons and daughters married and settled around him, and engaged in the iron business he had assisted in establishing. In his will he leaves his two thirds of Colebrookdale furnace and iron mines to his son Thomas, who by his marriage with Rebecca Rutter was already part owner in the Colebrookdale plant. Thomas was married twice and had seven children who lived to grow up. In his will he says: "I order my part of the furnace with lands, together with house and lands I now live on, to be rented out till my son David arrives at the age of twenty one years, and if he inclines to rent, to have the refusal." But David did not take the Colebrookdale furnace, nor did any of the others so far as we can learn, succeed to this fine old patrimony. In Nicholas Scull's map of Pennsylvania, I759, Colebrookdale furnace is located, and that was probably the period of its greatest activity. A stove plate cast at the furnace in I 763 was exhibited at the World's Fair in Philadelphia. 


\section{Chester County.}

Reading or Redding Furnace- so the name is spelled on old plans and maps-on French Creek, Chester county, the second in Pennsylvania, was built probably in 1720. It is said its site was at or near Coventry forge of earlier date. $^{1}$ For a time it was very productive, but the ore ran out and it was then dismantled and vacated. This is the short story of the original Reading Furnace. The second of the same name, built in 1736 or 1737 , was a mile distant from the first.

Their founder has a lasting record. As the quality of the root or the seed determines after growth, so does Samuel Nutt, land-buyer, iron worker and untiring builder of forges and furnaces focus in himself, as it were, all the possibilities of Pennsylvania's present iron industry. He was a member of the Society of Friends. Advanced religious thought and convictions doubtless helped to draw him to Penn's colony, but before leaving England and his town of Coventry on the $4^{\text {th }}$ of May, I 7 I4, he bought of Benjamin Weight of the same place I 250 acres in Pennsylvania, some of which were laid out in Sadsbury township. ${ }^{2}$ A characteristic act this, and before touching American soil he was already land-owner by purchase, not by grant. His certificate from the monthly meeting of Coventry dated Second month, Seventh day, I7 I4, was presented to Concord, Pa., meeting on the Tenth month, Thirteenth day

${ }^{1}$ History of Chester County, by J. Smith Futhey and Gilbert Cope, p. 345.

2 Ibid., p. 670. 
of the same year. ${ }^{1}$ There followed years of extraordinary initiative and accomplishment; his energy turned the hidden ore of the primeval forest into marketable iron. He soon came in touch with Thomas Rutter and Samuel Savage, Rutter's son-in-law. These men, Rutter and Savage and Nutt, are the three pioneers of Pennsylvania's greatest industry-her earliest "Iron Kings." Nutt probably in his work was not directly associated with the two others, but similar interests and experiences in the wild region of the upper Schuylkill welded these men together.

In Virginia English capitalists helped the early iron workers; these of Pennsylvania were men of means, as well as of ability, and they seem to have had, and to have asked no outside aid.

Having taken up land on the west bank of the Schuylkill, Nutt went thither in I7 I 6 or I7 I8, and built there as already stated, Coventry Forge and later Reading furnace. He is said to have returned early to England coming back with skilled workmen, and at French Creek the first steel in America was made. ${ }^{2}$ The following letter proves that he had set up a forge on French Creek before July, I720:

"Philadelphia, July 2nd i 720.

"My Good friend

"I was in hopes I should have seen thee at the Forge before this time but suppose some other Important affairs Prevented it-however since I had not that happiness; I make bold to Trouble thee with a ffew Lines; to acquaint that Wee proceed on; In our Intentions of putting up another fforge this ffal upon the ffrench Creek a Little above James Peughs upper Line and shall Dam up above the fforks of the North \& South Branches; so that we shall

1 Ibid., p. 67 o.

2 "Memorial of Thomas Potts, Jr.," by Mrs. Thomas Potts James, p. 3 . 
be under an absolute necessity of taking up all that Tract as lyes betwixt the said James Peughs line \& Phillip Rodgers upon the North branch \& although I do not think the Land is Inviting to any other body to meddle with it-yet if any one should attempt to do so; I desire thee to Interpose thy good offices In our favour \& in doing so thou will In a Perticuler manner obleige thy $\mathrm{ffr}$ to serve thee at all times "Sam. Nutt

"I intend to take a turn Down Into Chester County In a Little time $\&$ to pay thee a visit. In the mean time pray give my Respects to thy wife \& family and accept of the same Thy Self . . . vale

\section{(Addressed)}

"To Doctor Isaac Taylor at his House in Thornbury in Chester County"

From I7 I7 to I72I, the "absolute necessity" noted in the letter to Dr. Taylor, of taking up land, came frequently upon him and "very inviting" were the forest acres-for on October 2, I7I7, he obtained survey for two hundred and fifty, an iron mine therein included. This tract was patented to him in 17 I 8 and the warrant for taking it up dated September I8, I 7 I 8, called for four hundred acres. Another warrant October 2, I 7 I 8, called for eight hundred acres near the branches of the French Creek; three hundred acres of this were laid out in Coventry two years later. Six hundred and fifty acres on French Creek including the subsequent site of the Warwick furnace, were conveyed to him on May 2, I7 I9, and one hundred and fifty acres more on October I, I720. On May 23, I72I, he purchased from James Peugh three hundred acres on French Creek in Coventry. ${ }^{1}$

Years elapse and no more is heard of land ventures until

${ }^{1}$ History of Chester County, by J. Smith Futhey and Gilbert Cope, p. 344 . 
January 6,1732 or 1733 , when James Steel wrote from Philadelphia to John Taylor, the surveyor:

"Our ffrd Saml Nutt having paid a Good sum of money to me for the Prop's use hath requested a further addition to his Lands to accommodate his Iron Works, which the Proprietary was pleased to Grant him. I doe therefore request thee to make such surveys for him as may answer his purpose."

Long before this latest purchase, iron interests came still closer to him, in fact, iron entered into his hearthappily not into his soul-for in 1720 , or soon after, he married Anna, daughter of Thomas Rutter and widow of Samuel Savage, and thus Anna Nutt was daughter of one of the pioneers, wife, and for a short time, widow of the second, and wife of the third whom she also survived. ${ }^{1}$

Some of the acres referred to in the following order have special interest in connection with the marriage:

\section{"To Jacob Taylor Surveyor. General.}

"By the commissioner of Property. Pensilvania. ss.

"At the request of Samuel Nutt now of Chester County that we would Grant him to take up near the Branches of the ffrench Creek the quantity of Eight hundred acres of Land for which he agrees to pay to the use of the Trustees Eighty pounds money of Pensilvania for the whole, and the yearly quit rent of one Shilling Sterling for each hundred acres. These are to authorize and require thee to Survey or cause to be Surveyed unto the said Samuel Nutt at or near the place aforesaid according to the method of ye Townships appointed, the said quantity of Eight hundred acres of Land that has not been already surveyed nor appropriated nor is Seated by the Indians, and make returns thereof unto the Secretary's office, which Survey in case the said Samuel fulfil the above agreement within ....

1 Memorial of Thomas Potts, Jr., p. 29. 
months after the Date hereof shall be valid, otherwise the same to be void as if it had never been made, or this Warrant ever Granted. Given under our hands and Seal of the Province of Philadelphia ye $2 \mathrm{~d}$ October. Anno D'ni I 7 I 8.

RICHARD HILL,
ISAAC NORRIS
JAMES LOGAN."

To part of this tract Nutt gave the name of Coventry and from it to Philadelphia "a distance of 40 miles he laid out, it is believed, and made at his own expense the first road of any extent in the Province. It is still called by aged people in the neighborhood the Nutt or Great Road; it passes through Valley Forge, crossing the creek of that name near Washington's Headquarters."

On a hillside within these acres, near the branches of the French Creek, he built a home for his Anna and himself like the old houses in his English town-the frame of great hewn logs between which were cemented stones. No children were born to him in Coventry Hall but devotion to his wife's daughter, Ruth Savage, caused him to summon from England his nephew, Samuel Nutt, Jr., to be her husband. Fortunately the young people approved the match and the wedding took place Fifth month, seventeenth day, I733. The bride could not have been sixteen years old; her wedding dress was of brocade with high heeled buckled shoes to match, and tradition says, "her rich dowry was far outweighted by her personal and mental charms." Tradition also affirms that her step-father, Samuel Nutt, was the younger son of a baronet and the coat of arms he brought from England has on it a crescent, the mark of a second son. ${ }^{2}$

1 Memorial of Thomas Potts, Jr., p. 32.

2 Ibid., p. 3 r. 
In the imagination of Mrs. James-the historian of the Potts family-Samuel Nutt is pictured as "a fine English gentleman with no sign of the Quaker garb and plainness; the careful appointments of his magnificent horse, his lace ruffles and cocked hat, all show that he was a man having authority."1 Authority in reality he had, for he was member of Assembly from Chester county from 1723 to 1726 and when a new Commission of Peace was issued on Patrick Gordon's becoming Governor, Nutt was appointed one of his Majesty's Justices. Other indications of his high standing as a citizen are found. In 1728 , he was chosen with eleven others by the Governor and Council to run a division line to separate Lancaster county for the old Chester county, though he does not appear to have acted in this matter. His name heads a list of taxables in 1724. Emanuel Swedenborg, in 1734 , in a Latin treatise on Iron writes: "A works was built on the Schuylkill River by Master Samuel Nutt with furnaces and hearths." In Bishop's "History of American Manufactures," we read: "In I 7 I8, Jonathan Dickinson mentions in a letter that the iron works forty miles up the Schuylkill are very great." The historian adds: "the reference here was probably to the Coventry forge on French Creek in Coventry township, Chester Co. This bloomery was built by a person named Nutt who made other large improvements at the place."

The nearness of Nutt's furnace and home to the scene of the only hostility of the period in Pennsylvania between Indians and settlers, explains the following letter. Malanton, the place from which it was written, is a misprint for Morlatton, near Colebrookdale; part of it is now called Douglassville. It is forty-four miles from Philadelphia, on the Reading Railroad. It was settled early by the

1 Ibid., p. 5 I. 
Swedes, and the name is supposed to be derived from a district in Sweden. An old Swedish church still stands there, called St. Gabriel's. The Governor of the Province, news of trouble having reached him, had visited the region. Believing that affairs were again peaceful, he was about to return to Philadelphia when Nutt's communication reached him by express:

"Malanton, May i I I 728

\section{"May It Please The Governour}

"Just now I R'ved the Disagreeable news that one Walter Winter and John Winter have Murdered one Indian Man and Two Indian Women without any cause given by the sd Indians; and the said Winters have brought two girls (one of which is Crippled) to George Boon's to receive some Reward. I desire the Governour may see after it before he goes Down, for most certainly such actions will create the greatest antipathy between the Several Nations of Indians and the Christians. The Bearer John Petty has heard the full relation of this matter, to whom I shall refer the Governour for a more full account and remain the Governour's most hearty friend and Serv't to Command.

\section{SAMLl NuTt."}

Immediately upon the receipt of this letter, the Governor issued a proclamation, commanding the people, in his Majesty's name, "to levy Hue and Cry with Horse and with Foot within the Province of Pennsylvania," for the apprehension of these murderers who were afterwards tried, convicted and hanged.

The circumstances connected with this one unfortunate episode in the otherwise peaceful relations of the Pennsylvania colonists and the Indians are strikingly picturesque and rich in the coloring of the wild places and the time.

In 1736 , the second Reading furnace recently built, was 
handed over by Samuel Nutt and Wm. Branson, joint owners, to John Potts, to carry on upon the following terms." He was "to cast the quantity of twenty-eight hundred weight of Cart Boxes, Sash Weights or any other Particular small Castings every Month during the Continuance of the said Blast. . . . And they also covenant that ye said Owners or their Clerks or Agents for the Time being, shall deliver no Quantity of Rum to any of the People Belonging to the Furnace or therein concerned, without a Note or Token from the said John Potts or his Agents or Assistants."2

In an inventory taken of the estate of Nutt when starting his partnership with Branson, mention is made of "a ring round the shaft at the old furnace." and of "one tonn of sow mettle at the new furnace."

Over Nutt's signature we have a glimpse of labor conditions in an advertisement from the Pennsylvania Gazette, July I737, for a run-away. The man was a Redemptioner or Redemptionist, the name used to designate persons sold on arrival by contractors or captains of ships to pay for their passage from abroad.

\section{"French Creek Iron Works Chester County}

$$
\text { "July 34d I737. }
$$

"Run away from the iron works aforesaid, a servantman David McQuatty; by trade a Hammerer \& Refiner, but has forermly followed shaloping up \& down the Bay from Egg Harbor. He is a Scotchman but speaks pretty good English, middle siz'd about 28 years of age of a thin visage $\&$ a little pockpetten, with a Roman nose \& a few spots of Gunpowder under his right eye.

$\mathrm{He}$ is a talkertive man, given to liquor, \& then very quarrelsome $\mathrm{He}$ has such a trembling in ther nerves that

${ }^{1}$ Memorial of Thomas Potts, Jr., pp. 34 and $35^{\circ}$.

2 Ibid., p. 5 r. 
he can hold nothing in his hands steadily, he has a very small mouth and thin lips. He had on when he went away, a new drugget coat \& jacket of a kind of yellowish or snuff color-a good new fine shirt-a new castor hat-a darkish silk handerkerchief-a cotton cap-a pair of new linen drawers or a pair of Osenbrigs trowers, \& a pair of lrge carved brass buckles in his shoes.

"Whoever secures the said servant so that his master may have him again, shall have $£_{3}$ if taken up in this Province, or $£ 5$ if taken up in any other Province \& all reasonable charges paid by

\section{SAMuel NutT" 1}

Samuel Nutt was busied with his chosen work until the end, for he died in I737. The inventory of his estate taken in May, I738, is divided into two parts. That which he held in company with Wm. Branson amounted to $£ 29$ I 2 ; to be divided equally between them. His private estate amounted to $£_{5444}$.

The following extract from the inventory of the private estate contains items characteristic of the time:

One tonn of sow mettle at new ffurnace

$\mathrm{L}_{5-\mathrm{IOS} .0}$

I 8 Stove plates ro cwt.

L.8- I $6 \mathrm{~s} .0$

The mine trace containing 250 acres of land L I 500-0.0 650 acres of land in Nantmill on which the

new ffurnace is building with Sundry out-

houses

267 acres of land in Coventyr being the land

on which Samuel Nutt's house stands

A negro boy named "Cudjo"

A negro boy named "George"

2 hhds Rum

$\mathrm{L}_{525}-0.0$

78 ells Oxenbrigs ${ }^{2}$

$\mathrm{L}_{300.0 .0}$

$\mathrm{L} 30.0 .0$

L I $5 \cdot 0.0$

L.26-Is.0

L 7-7s.o

1 Memorial of Thomas Potts, Jr., pp. 51-52.

2 Ozenbriggs. A very heavy linen, made originally at Osnabrück, Hanover, used in great quantities in America during Colonial times for shirts, breeches and clothing for hard use. It was sold in large bales, particularly in the South, for use by the slaves. 
His will, dated September 25, I 737, bequeaths one half of his estate in Reading furnace and Coventry forge to Samuel Nutt, Jr. and Rebecca, his wife, and the other half after payment of some legacies, to his own wife, Anna. He particularly directs that she is to have one hundred and twenty acres of land on the South Branch of French Creek one hundred and thirty perches in length on which to build a furnace, and leave to cut as much timber upon the lands adjacent as would suffice to erect the same. His idea seemed to be that she and her sons might carry on this establishment while her son-in-law managed Coventry. ${ }^{1}$

Nutt's busy brain glowed, while his mortal life flickered, with thoughts of the furnace that his wife and her sons were yet to build. He then lighted fires which burned for many decades and the land on which stood Warwick furnace, is still owned by the descendants of Anna, wife of Samuel Nutt, Sr. ${ }^{2}$

For forty years, from the time of Nutt's death, little or nothing is found recorded of the Reading furnace. In I777 it blazes forth with unexpected brilliancy; for a letter from Washington written on his memorable way between Brandywine and Valley Forge with an impoverished army, is dated:

"I9 September I777.

"Reading Furnace, 6 o'clock P. M.

"Dear Sir. I have received yours of half past 3 o'clock having wrote to you already to move forward upon the enemy, I have but little to add-Generals Maxwell \& Potter are ordered to do the same, being at Potts' Forge. I could wish you and these generals would act in conjunction to

1 Memorial of Thomas Potts, Jr., p. 53.

2 History of Chester County, by J. Smith Futhey and Gilbert Cope, p. 211. 


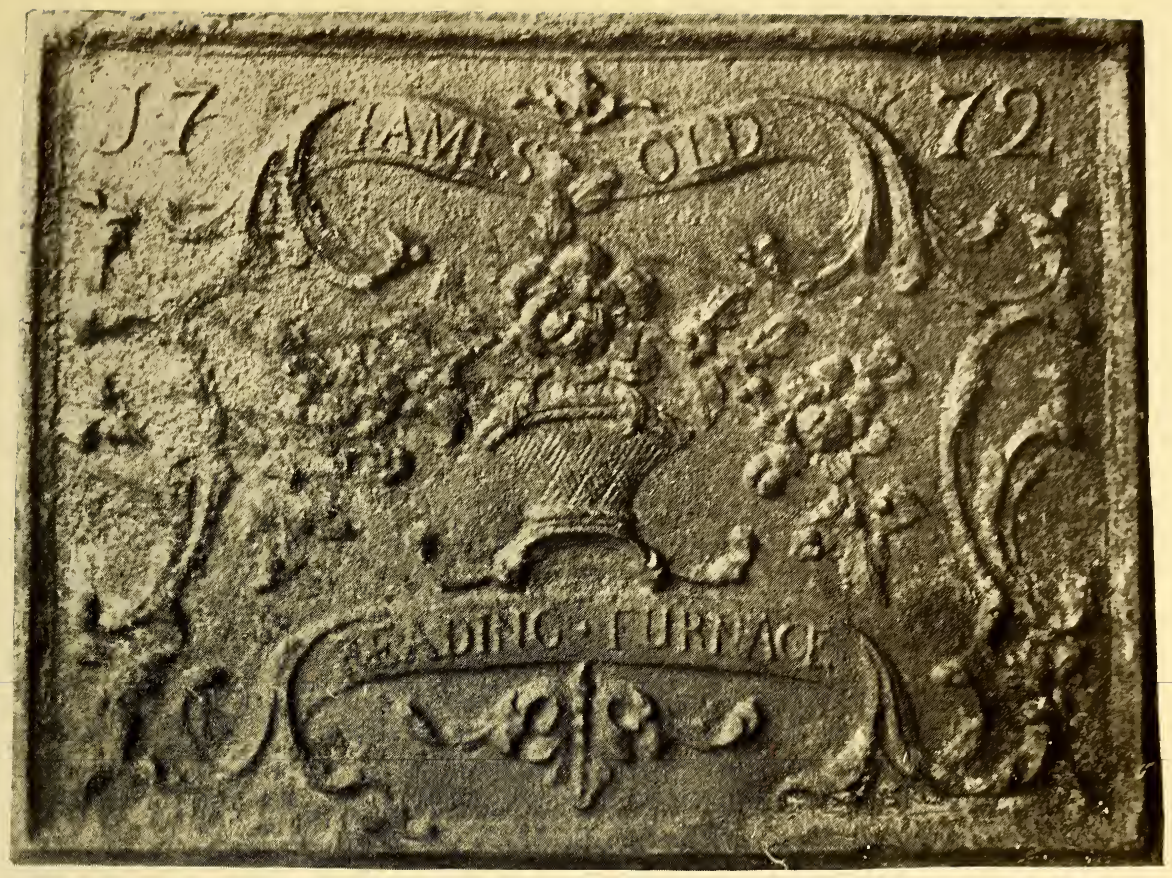

Stoveplate, Reading Furnace, i772. Owned by the Pennsylvania Museum in Memorial Hall.

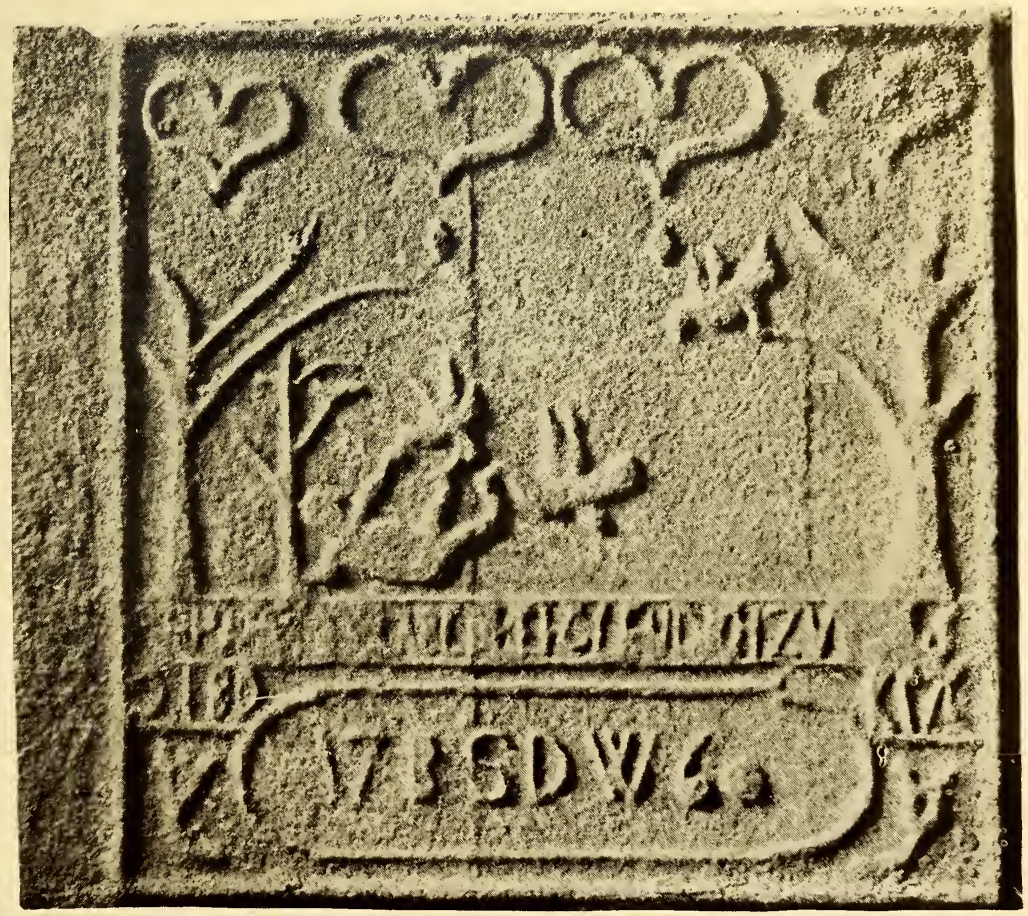

Plate, 1766. 

make your advance more formidable, but I would not have too much time delayed on this account. I shall follow as speedily as possible with jaded men-some may probably go off immediately if I find they are in condition for it. The horses are almost all out upon the patrol. Cartridges have been ordered for you. Give me the earliest information of everything interesting, \& of your moves, that I may know how to govern mine by them.

The cutting off the enemy's baggage would be a great matter, but take care of ambuscades,

Yours sincerely

George Washington. ${ }^{1}$

Gen. A. Wayne

Baker's Itinerary gives details of Washington's movements at this time ${ }^{2}$ but makes no mention of Reading; this letter proves his presence there.

Here its story ends for us. Upon the foundations of Colonial government and English traditions rises the changing order of a new nation,- the home of all races, the land of the people's rule. Let it not be forgotten, now that Pennsylvania's iron wealth is one of the largest material assets of our great Republic, that Washington, when his faith in its future was most sorely tried, tarried awhile at Reading Furnace.

Eliza B. Kirkbride.

1 Ege Genealogy, p. 79. The original letter is in the Wayne Collection, Historical Society of Pennsylvania.

2 Itinerary of Gen. Washington, by Wm. S. Baker, p. 9r. 


\section{SIR WILLIAM KEITH'S FURNACE.}

\section{Lower Counties.}

Sir William Keith, the last deputy governor of Pennsylvania appointed by William Penn, was born in England in 1680 and died in that country in 1749 . He was heir to an empty Scotch title, being descended through the renowned Keiths of Ludquahairn from many of the nobility of North Britain, his own family having been formerly rich and powerful, and at one time reckoned amongst the greatest in the Kingdom of Scotland.

Sir William had been well educated by an uncle, and inherited much of the ability and statesmanship characteristic of his race and name.

He was early in life appointed by Queen Anne, Surveyorgeneral of the royal Customs in the American Colonies at a salary of 500 pounds per annum. He spent many of his days at this time in the colony of Virginia where the generous mode of living of the wealthy planters, and the beauty of the Southern women were much to his taste.

The accession of the Hanoverian line to the throne cast Keith out of office, and he came north to Philadelphia. Shortly after this, having obtained through the influence of his friends the appointment of deputy governor of Pennsylvania, he immediately brought his family from England, arriving in Philadelphia on the 3 Ist of May I7 I 7.

The governor's household consisted of his second wife, Lady Keith, her daughter by a former marriage, Anne Diggs, his three sons, Alexander Henry, Robert, and William Keith and his young kinsman, a Scotch physician, 



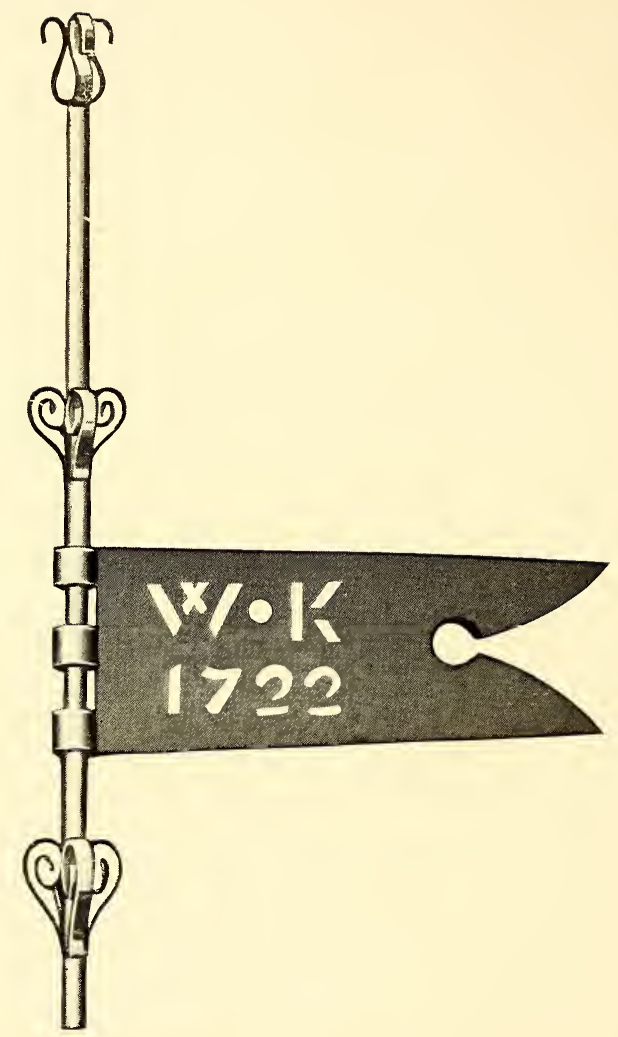

Wcather Vane from Residence of Sir William Keith, Graeme Park. Owned by the Historical Society of Pennsylvania. 
Thomas Graeme, who later married his stepdaughter, Anne Diggs.

In I7 I9 Sir William Keith bought a large tract of twelve hundred acres of what was then wild land, nineteen miles from Philadelphia in Horsham township, Montgomery county, two miles northwest of the Doylestown and Willow Grove turnpikes, and in I72 I built a house sixtyfive by twenty-five feet in size, two stories high with a gambrel roof, the walls of stone and over two feet in thickness, the kitchen and offices detached and flanking each side of the main building. The drawing room is a fine room for those times, twenty-one feet square, with a fire place having the coat of arms over it, and adorned with marbles brought from England. Dutch tiles, then much in fashion in the colonies, were used in the other rooms. The house is panelled throughout in oak, and has a good colonial stairway. It was probably finished in I 722, this being confirmed by the old iron weather vane formerly upon it. This old vane was in I 855 in the possession of Hugh Foulke of Gwynedd, who is said to have purchased it from the Lukens estate in 1829 for old iron.

"It was of wrought iron, thirty-eight inches in length. The part bearing 'W. K. I722' which was seventeen inches in length was cut out in it after the manner of a stencil. At the lower part was a screw with which it might be secured to its place."

There is also an iron plate in a hearth in a second-story bedchamber bearing the date of 1728 . On this estate Sir William Keith lived in great style with seventeen slaves, four horses for his coach, seven riding horses and nine for farm work. The grounds were mostly maintained as a hunting park and stocked with deer and other game.

This mansion and grounds were later bought by Keith's son-in-law Thomas Graeme, and were known as "Graeme 
Park." The house is still standing though in very bad repair, and the grounds left to run wild. Sir William Keith's granddaughter, Mrs. Fergusson, inherited the estate, and it was finally sold to Samuel Penrose whose family still own it.

Sir William Keith's administration as Governor of Pennsylvania lasted from June I 7 17, to I726. Probably about I 724 he bought a tract of land in Delaware (then part of Pennsylvania) at Iron Hill on Christiana Creek, near Newcastle, where he built the first iron furnce and forge in Delaware. In I 7 I 7 he wrote to the Board of Trade in London that "he had found great plenty of iron ore in Pennsylvania."

Emmanuel Swedenborg in his "DeFero" printed in I 734, mentions smelting works on Christiana Creek built by Sir William Keith in the latter part of his administration, which produced large quantities of iron in the first two years of their existence, but were abandoned the next year owing to the difficulty of smelting the ore. All traces of this forge and furnace seem to have disappeared, nor is there to be found any specimen of the work.

Margaret C. Yarnall Cope. 
MCCALL'S OR GLASGOW FORGE.

\section{Philadelphia, Now Montgomery County.}

Along the banks of the Manatawny Creek, which rises in Rockland township, Berks county, and empties into the Schuylkill River at Pottstown, several furnaces were situated, among them McCall's Forge or Glasgow Forge, by either of which names, according to Colonial records, the place seems to have been equally well known. The tract of land containing it was conveyed in trust by William Penn to his son John, October 25, I 70I, and comprised all of the present township of Douglas and the upper half of Pottsgrove; and the whole of Pottstown to the Schuylkill, I 4,600 acres in all. This was sold by John Penn, June 20 , I 735, for the sum of two thousand guineas, - $\$ 9,333$ - to George McCall, the son of Samuel McCall of Glasgow, Scotland." "Fully ten years before the date of this purchase, in company with Anthony Morris, 3 rd, George McCall had erected an iron forge (called "McCall's Forge," on Scull's map of I 759) at Glasgow on Manatawny Creek, which he named for the place of his nativity. Some time after, he engaged Nicholas Scull to survey plantations on a certain part of his property for which he permitted his five sons to draw lots."

He had also an interest in Colbrookdale Furnace, then managed by Thomas Potts, Jr., which supplied McCall's Forge with pig iron. ${ }^{2}$ Thomas Potts, Jr., was acting for Anthony Morris, who was a relative of his, and also for George McCall, in the management of McCall's Forge.

${ }^{1}$ McCall Family, by Frank Willing Leach.

2 History of Montgomery County, by W. J. Buck. 
A merchant of note and enterprise, $\mathrm{McC}$ all rapidly acquired a fortune. He had a store and wharf at Plum Street; and was said to have invested largely in real estate. In I 722, he was elected a member of the City Council. He married Anne Yeates in 1716 ; was a vestryman of Christ Church, and in I 7 I 8, a tenant of the parsonage house, contributing largely to the rebuilding of the church. ${ }^{1} \mathrm{He}$ died in I740, and by his will, dated September 21 , I739, bequeathed 500 acres of what, until I753, was known as McCall's Manor, to his son, Alexander McCall, and which subsequently became known as the Forge Tract. Here the McCalls, Samuel, Archibald and Alexander, engaged extensively in manufacturing interests, and operated the old forge and a grist and saw mill. Samuel McCall, on September 8, I752, sold the old forge property to Joseph and John Potts and James Hockley, and in 1789 , it was sold at Sheriff's sale to David Rutter and Joseph Potts, Jr. Later in the same year Rutter sold his share to Samuel Potts, and it continued in the Potts family until 1832 .

In 1820 , there were at the place a small sheet iron mill, two bloomeries, a grist mill, a saw mill, two mansion houses, ten log tenant houses, and two stone tenant houses, and at the present time work is carried on there by the Glasgow Iron Works and Rolling Mills.

As the name Manatawny (meaning, "the place where we drink"), indicates, there were a number of Indian tribes in the neighborhood, who viewed with dismay the large amount of wood used to make charcoal for the furnaces. To their far-sighted Chiefs, this wholesale destruction of woodland presented a melancholy picture and possibly contributed not a little to their disaffection.

Probably the life at forge or furnace in those days differed not materially from that of the sixties in the last cen-

1 Descendants of Jöran Kyn, by Gregory B. Keen, p. 766 
tury, when the workmen lived scattered over several miles of country, and were wakened to come to work by one long blast of five minutes, blown at four o'clock in the morning. So much a subconscious part of the day's routine had this whistle become, that the manager of one iron works was startled awake one morning by the fact that the whistle had not blown, and by inquiring the reason from the engineer later in the day, confirmed the impression that "it was no use trying to fool 'Mister' even when he was asleep."

Margaret Wister Meigs.

\section{KURTZ'S IRON WORKS.}

Kurtz, possibly an Amish Mennonite, is supposed to have established iron works in Lancaster county in 1726. Egle says on Octorara Creek. These works are said by Day to have been the first in the county although Peter Grubb's were a close second. Information about this undertaking is not to be found in the usual records. 


\section{ABBINGTON FURNACE.}

\section{LOWER Counties.}

In I70 I Welsh settlers coming to Delaware from the "Welsh Tract" in Pennsylvania, obtained from William Penn a grant of three thousand acres of land which was known as the "Welsh Tract." Most of this Welsh Tract, of the lower counties, is in Pencader Hundred.

One of these settlers, James James by name, selected Iron Hill and the land northward to Christiana Creek, twelve hundred and twenty-four acres in all, and had deed for it from William Penn in 1703.

Iron Hill is the most marked feature of the neighbourhood, and is mentioned by name in a letter of May, I66r, in which Vice Director Hinijossa relates the killing there of four Englishmen by the Indians.

Part of this land coming to Samuel James, son of James James, he built upon it a forge about I723. His success, and the iron ore near-by attracted the attention of some of the leading iron masters in Pennsylvania, eight of whom formed a company of which Thomas Rutter was one, and in 1726 erected on Christiana Creek a furnace and forge to be called "Abbington Iron Works." They, however, never made a success of it; Samuel James continued the works until 1735, when they were finally sold out by the sheriff. Since that time saw mills and grist mills were operated there until a fire in 1883 made an end of the whole plant.

Curiously enough, (I9I3) the site of these old iron works, three miles from Newark, Delaware, has been bought by a Philadelphia capitalist, and is now in the hands of experts, German and American, who confidently expect to make these old pits profitable, in the production of platinum and gold.

Margaret C. Yarnall Cope. 


\section{DURHAM FURNACE.}

\section{Bucks County.}

From time immemorial, whenever a new country has been about to be settled, there has been included in its concessions, charter rights or other legal agreements, some mention, at least, of the mineral wealth which later occupation of the territory might disclose. The "Conditions or Concessions" which accompanied William Penn's "Frame of Government," in the sixth clause, reads : "That notwithstanding there be no mention made in the several Deeds made to the purchasers, yet the said William Penn does accord and declare, that all Rivers, Rivulets, Woods, and Underwoods, Waters, Water-courses, Quarries, Mines, and Minerals (except Mines Royal) shall be freely and fully enjoyed and wholly, by the purchasers into whose lot they fall."1 But however far-reaching their outlook, William Penn and his associates little dreamed of the vast stores of wealth and energy locked up in the coal and iron mines of his beloved Pennsylvania. It is certain that the earliest settlers in the province,-the Swedes,-were informed of the existence of iron ore in several parts of the eastern division of Pennsylvania, but meagre resources did not permit of any development of mining, in the modern sense.

Of the three counties into which Pennsylvania was originally divided, Bucks was the easternmost. The subdivisions of this county into townships, left one of the smallest of these, known as Durham, in the extreme northeastern corner. Much earlier in date than its neighbor,

1 Colonial Records of Pennsylvania, Vol. I, p. xix. 
Northampton, [Easton], which was not settled until I 752, there were white settlers in the township of Durham in I682. James Claypoole wrote on June 4th of that year: "We are to send one hundred men to Durham to build houses, to plant and improve land, and to set up a glasshouse for bottles and drinking glasses, and we hope to have wine and oil for merchandise, and hemp for cordage, and iron and lead and other minerals." 1 A beautiful stream, known as Durham Creek, enters the Delaware in the extreme northern portion of the county, and about a mile and a half from its mouth are the remains of a curious cave, which is the earliest relic of the white man's effort to heat and mould iron near the spot. This great natural cavern was regarded as a wonder, and visited by every newcomer or prospective settler, and famed afar, before it was blasted and its beauty ruined in order to quarry its limestone. The frequent Indian village sites in the township furnish to the antiquarian many fine specimens of pipes, pottery and stone, important for the use of the student.

It is interesting to note that William Penn became an owner of land in New Jersey, Andover Township, in what is now Sussex County, by a warrant from the Council of Proprietors dated March I0, I 7 I 4. Later on, about I 760, this region, containing one of the richest mines of iron ore in New Jersey, was opened up and a furnace set in operation. The product of these Andover Iron Works was carried upon pack-horses and carts down the valley of the Musconetcong to Durham on the Delaware, and thence transported on "Durham Boats" to Philadelphia.

In the year I7I7 (September 8th), a portion of Durham township was patented to Jeremiah Langhorne, and John Chapman. Another, of twelve hundred acres, was deeded to Langhorne alone, but the larger part, by warrant

1 Penn-Logan Correspondence, II, p. 323. 
and survey, became the property of James Logan. A famous Indian Treaty was begun at Durham in I734, adjourned to Pennsbury, and finally concluded in Philadelphia, August 25, I737. The infamous "Walking Purchase" was completed through this section, September 2oth of this year.

The iron ore in the neighborhood drew the attention of the settlers, and in 1726 a company was formed to erect a blast furnace, manufacture pig-iron, cast pots and pans, and make firebacks. The furnace was located at the village of Durham, near a school and church, and was probably the second erected in Pennsylvania. James Logan in I 728 wrote to William Penn, "There are four furnaces in blast in this colony." One of these we know to have been Colebrookdale; it is probable that the others, besides Durham, were located on French and Christiana Creeks.

Among the fourteen original owners, James Logan is said to have held one fourth part. Jeremiah Langhorne of "Trevose," Bensalem Township, "Gentleman," was another large owner, and others were Anthony Morris, brewer, Chief Justice William Allen, from whom Allentown takes its name, Joseph Turner, Robert Ellis, George Fitzwater, Clement Plumsted, John Hopkins, and Charles Read, father-in-law of James Logan, all described as "merchants." To these were joined Andrew Bradford, the famous Colonial printer, and Thomas Lindley, "anchorsmith." Griffith Owen and Samuel Powel were trustees.

A visitor to the Centennial Exposition at Philadelphia in I 876 might have seen among the curiosities connected with the manufacture of iron and the industries, an old stone of peculiar shape bearing the date I727. This was the keystone of Durham Furnace, of honorable history. Operations were begun at the new furnace in the autumn of 
1727, and in November of the following year James Logan shipped three tons of pig-iron made at Durham to England. The furnace is described ${ }^{1}$ as built of stone, thirty five to forty feet square, widest at bottom, and thirty feet high. The large leather bellows used to increase the blast was operated by a water-wheel turned by the creek. The iron was dug close by the furnace, and the charcoal fuel used in the process was made in pits, which being located close at hand, filled the air with a disagreeable odor from the wigwam-like structures which covered them, and in which the wood for the charcoal was burned. From the top of the furnace, into which were poured the ore, charcoal and limestone, issued at intervals bright flames which lighted up the picturesque surroundings when the blast was forced, and illumined the dark forest and its darker negro and Indian inhabitants, as the twilight shadows fell. The intermittent character of the work permitted the farmhands, who were negro slaves during most of the colonial period, to pursue their work on the farm near by in the interval of filling and drawing off the ore. When the iron was ready to be tapped, a horn was blown and the slaves presented themselves. The foreman or founder, with an iron pole or bar, opened or "tapped the bottom of the furnace, allowing the molten iron to run into the moulds of sand below. Durham turned out about two tons of iron in the day of twenty-four hours. Two tons of iron ore yielded one ton of pig-iron." Acrelius, writing in I 758 says, "Durham may be regarded as the best ironworks in the country. It has a rich supply of ore, water, sand and limestone. The ore is so near the furnace and the furnace so near the forges, that there is not three quarters of a mile of hauling about the works. The forges are little more than a mile to the station on the Delaware River, whence the iron is conveyed by water to Philadelphia."

1 F. Von A. Cabeen, The Colonel and the Quaker, p. 8x. 
Dr. John W. Jordan furnishes an interesting item, showing the varied existence of one of the Durham slaves called Joseph, or "Boston." Born in Africa in I7 I 5, at the age of twelve he was taken with a cargo of slaves to Charleston, South Carolina, where he was sold to a sea captain, who took him to England in 1727 . In $\mathrm{I}_{732}$ he was sold to the Island of Montserrat, and thence with a new master was brought to Durham Furnace, with ten other slaves. In 1747 he was living in the household of Squire Nathaniel Irish, and while there was married to "Hannah," but his master hired him to a furnace in New Jersey. In 1752 he was baptized by the Moravians at Bethlehem, and his owner, John Hackett, of the Union Iron Works, Hunterdon County, New Jersey, in I 760 sold him for fifty pounds to the Moravians. He died on September 29, I78 1 . "Hannah" was born July II, I 722, at Esopus, New York, and in 1748 , with her son, was sold to the Moravians for seventy pounds. She died November 24, I815.

In locating their furnaces through the wilderness, as was necessary in order to procure fuel supplies, these pioneer iron-masters were obliged to reckon with the Indians, who were becoming increasingly dangerous upon the frontier. Nevertheless, the peaceable Quaker tactics pursued by the furnace owners appear to have succeeded in gaining for them general immunity from disturbance. There was a good deal of traffic with the Moravians near the middle of the century. One Durham memorandum reads-

The Moravian Company,

May 28, I 745 .

Dr. To Robert Ellis \& Co.

For I ton I 5 lbs. Bar Iron ............... £30 4"

There is reason to suppose that as early as $\mathrm{I} 734$ there 
were two furnaces here, ${ }^{1}$ but the fact that Durham was owned by a large company may partially at least account for its neighborhood being very sparsely settled before the period of the Revolution. There was local government, and the furnace formed not only the industrial but the financial and social centre, around which all the interests of the community, simple and primitive to a degree, revolved. Accounts were kept here, as in all the iron manufactories in the colony, with every purchaser, and the transactions were in kind. Trade was in every possible commodity, from tobacco, bonnets, shoes and tea, to oxen and hides, wood and lumber. The remarkable collection of ledgers and account books of the old Pennsylvania furnaces, owned by ex-Governor Pennypacker, shows an almost patriarchal system of life going on in the country regions about these great iron centres, each a complete community within itself, supplying all the actual necessities of life, and for those days, even some of the luxuries, if among these we include molasses, rum, and tobacco! The private account books of Richard Backhouse, who bought Durham Furnace when it was confiscated during the Revolution, are among the oldest original records connected with Durham, and were given to ex-Governor Pennypacker in 1862 by his grandfather, one of the owners. They begin with the accounts of a village store keeper in Anne Arundel County, Maryland, and name payments for "Rumm, striped linen, osnabriggs, flannel, and a Boyes Hatt," the latter probably of beaver, at "Three and six." Osnabrigg was a heavy homespun linen, named from the German town whence it came, and largely used for shirts in the Colonial period.

Firebacks and stove plates were made at Durham from its first year, I 727, until I794, when operations were sus-

${ }^{1} \mathrm{~J}$. M. Swank, Iron Making in Pennsylvania, p. 17. Scull's Map of Pennsylvania for 1759 shows an old and a new furnace at Durham, as well as a forge-a second forge was built before 1770 . 



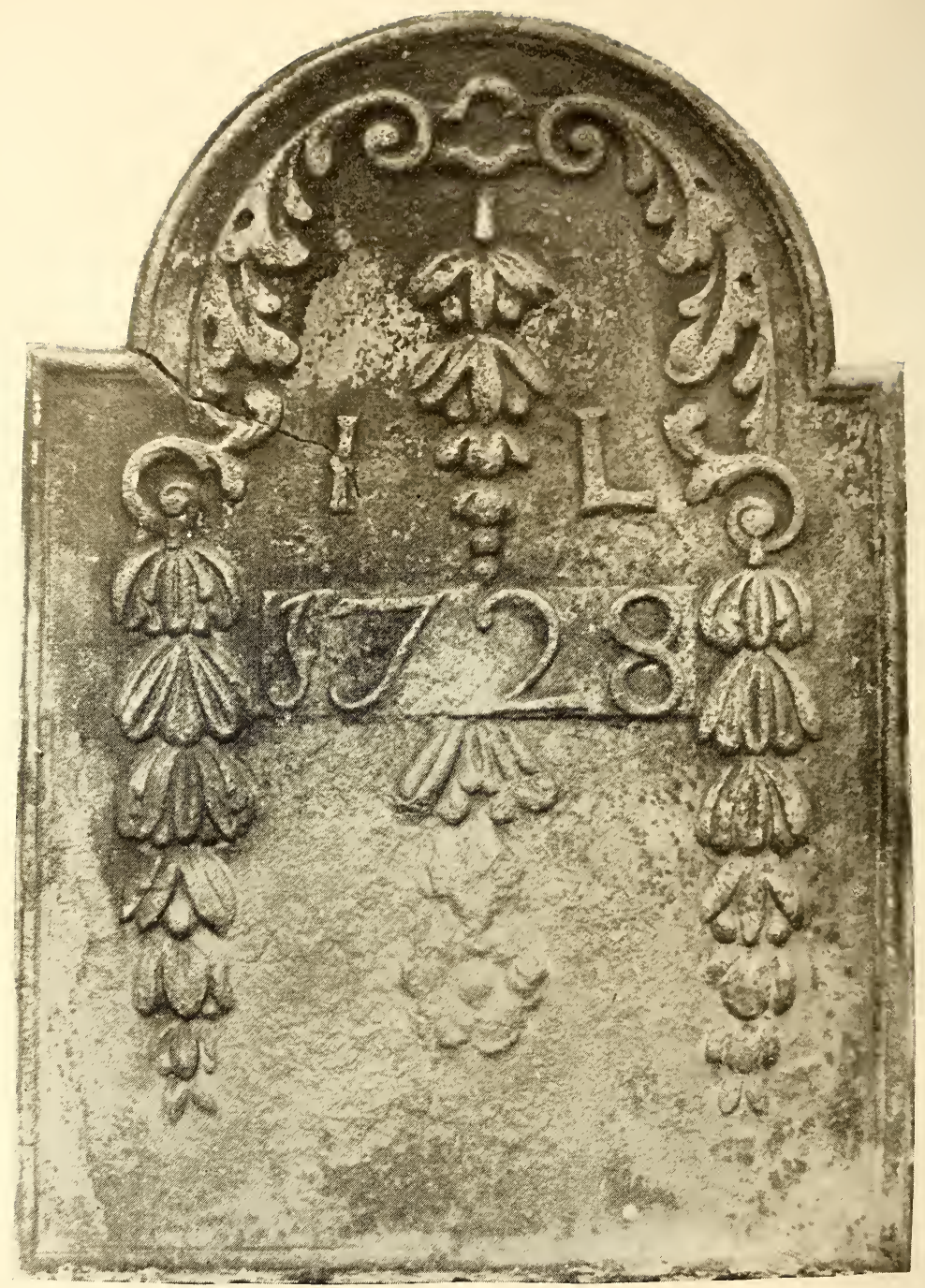

Fireback at Stenton, the residence of James Logan. Made at Durham Furnace. 
pended. A fine example of a Durham fireback is at Swiftwater Inn, near Pocono, in Monroe County. The earliest examples, however, of Durham firebacks are undoubtedly those at Stenton, the home of James Logan near Philadelphia. Here may be seen today eight of these early backs. Three of them bear date 1728 , at which time James Logan was owner of one fourth part of Durham Furnace; this was also the year in which was made the first foreign export. On one of the backs are the initials "I L." Stenton was built in this year and there is no reasonable doubt that the backs are genuine Durham productions. In order, however, to render assurance doubly sure, the committee were gratified to be able to refer the question to an expert. Mr. B. F. Fackenthal of Riegelsville, ${ }^{1}$ for years a student of the history of the iron industry, and a scientific chemist in this department of the arts, kindly examined into the matter for us, and we are glad to be able to quote his authority. Borings were carefully made by him September I 2, I9 I 2, and the chemical analysis that followed proved clearly that the iron from which the interesting old backs were made, was of the same composition as that produced at Durham.

The decorative stove plates of a rather later date are even more attractive to the antiquarian than the firebacks. Many of these have inscriptions in German, and some light is cast upon this feature when we recall that the Deed of Partition for the Durham tract was drawn in 1773 ; that administration as a township began in Durham June I3, I775; and that after one thousand acres were reserved for the purpose of the furnace and iron manufacture, the remaining portion of the tract was largely settled by Germans. Many of the inscriptions on these old stoves run

${ }^{1} \mathrm{Mr}$. Fackenthal was until recently president of the Thomas Iron Company, of Easton, Pennsylvania. 
around all the sides, and are in German. One, for instance, known as the "Adam and Eve," reads, "Die Schlang Adam und Efa Betrug." (The snake betrayed Adam and Eve). Another is the "Cain and Abel"; "Cain Seinen Bruter Awel tot Schlug." (Cain killed his brother Abel). Both of these date from I 74I, the earliest preserved, and show the Durham analysis. Some of the plates bear towering grenadiers, and refer to the Hessians who frequently settled in this country, many of whom never returned to their native land. An interesting journal of this period is the "Travels Through Berks County in I783," by Dr. John D. Schoepf, Surgeon of German Auxiliary Troops in the Service of England. ${ }^{1}$

Travelers on the way from distant points often made détours to see the wonders of the furnace, even at some expense of time and trouble, for colonial roads were bad indeed. Thus Elizabeth Drinker, whose Diary is a mine of information as to the mode of life at this period, mentions a visit to Durham. Her distances are not accurate, but the trip was by chaise to Brunswick, New Jersey, with digressions for visits. She writes under date

"September 3, I764.

"Left home after dinner, R. Booth on Horseback, and his man Robert, H. Drinker and Elizabeth" (herself and husband) "in chaise: Drank tea at Red Lion, I 3 miles from Philadelphia, lodged at Alex. Brown's I 3 miles from town: good accommodations. Breakfasted there $\mathrm{y}^{\circ} 4^{\text {th }}$ : then went to James Morgan's at Durham Iron Works, 48 or 50 miles from home. Roads very bad: stayed there to dinner: walked to the furnace, where we saw them at work casting iron bars, \&c."

The pig-iron and other products of Durham furnace must, when completed, be transported to Philadelphia, as the nearest distributing centre. The broad Delaware

1 Pennsylvania Magazine of History and Biography, Vol. V, p. 74. 


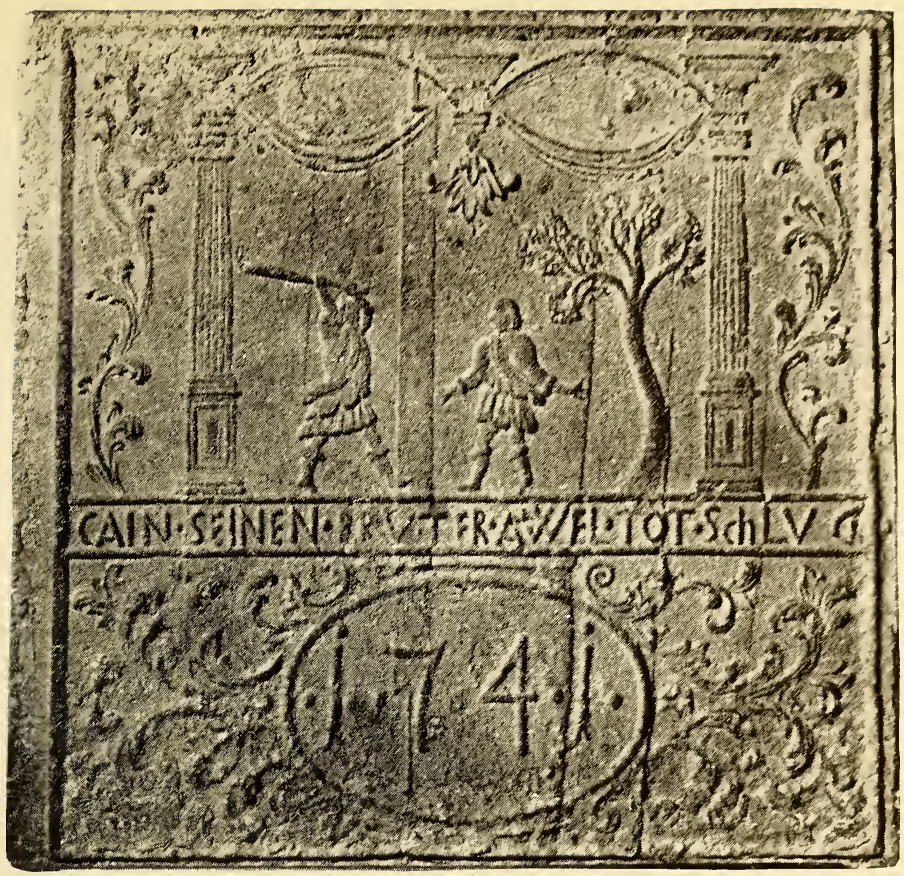

Cain and Abel. Durham Furnace. Owned by Pennsylvania Museum in Memorial Hall.

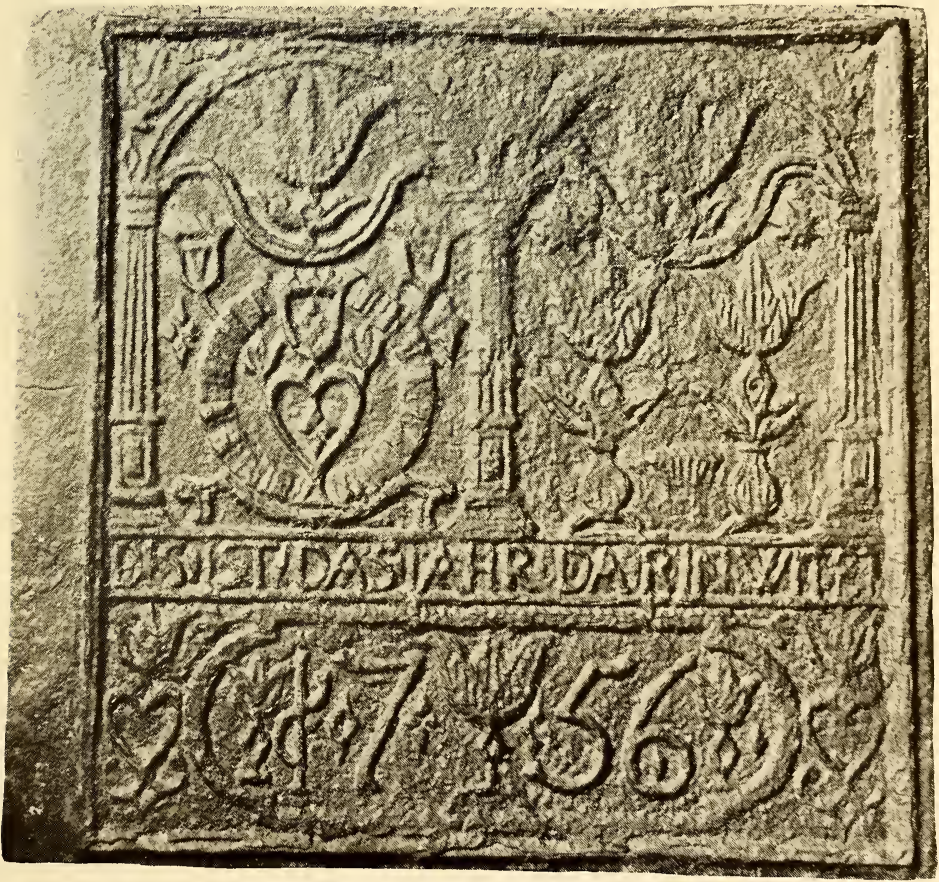

Stoveplate, Durham Furnace. Owned by Mr. H. C. Mercer. 

offered of course the only means of transportation, but there lay between the tidal river, which begins below Trenton, and the reaches of the upper Delaware, at "The Forks" (the early name for the point where the Lehigh enters the Delaware, at what is now Easton), a succession of rapids and falls dangerous in the extreme for the ordinary boats for burden-carrying, then known to the Englishman. Wells Falls, Foul Rift and Rocky Falls, still bear their ancient reputation for the modern canoeist. An old map published in London, in I648, calls the Falls at Trenton "The Falls of Charles River," by which name the early navigators knew the Delaware. These later became the "Falls of Delaware." Fallsington still lingers in memory of this. The rocky channel, in a distance of thirty-five hundred feet, has a fall of ten feet. No ordinary craft could carry a load through this rapid.

In the solution of the problem Indian woodcraft, as often before, was applied, and the graceful canoe of the aborigines became the model for what is still known as the "Durham boat." Abraham Haupt, a German blacksmith whose shop stood near the original furnace, some distance back from the river, gives the earliest information regarding these interesting boats. It was in Haupt's shop that the date-stone referred to was found, used by his men for cracking nuts, which accounts for the depression plainly shown in the photograph! Haupt asserted that the first Durham boat was built near the mouth of the cave by Robert Durham, engineer and manager of the furnace, after the model of an Indian canoe, and that the works were probably named after the builder of the boat. The boats were in use within ten years after the first shipment was made, and the Durhams were settled in Bucks County as early as 1723 . These boats were used on the Delaware, and also on the Susquehanna, for more than a century, for every purpose of freight and produce-carrying. The raft 
and the coal "ark" could make the descent of the river, under skilled guidance, but they were unable to perform the return journey, and were themselves sold as a part of the cargo upon arrival at their destination. Only the staunch and sharp Durham craft could be forced up against the swift and dangerous current. ${ }^{1}$ The shape of the Durham boat was very long in proportion to its width, its sides being nearly vertical, a slight curvature only meeting a similar curve at the bottom, which was quite flat. Fore and aft, the sides were straight and parallel, curving in to meet the stem and stern posts at about fourteen feet from the end, at which point the boat was decked over, the middle of the boat being open. The usual length was sixty feet, width eight feet, with a depth from top of gunwale to the twelve inch keel-plank of forty two inches, with the additional height of some ten inches at the ends. These flat boats, with no loss of space, usually carried from fifteen to twenty tons down the river. The return journey, with the load consisting of products for home consumption and Indian trade or barter, was reduced to about two tons, from the necessity to maintain the readiest response to guidance possible.

Coming down stream, the boat floated with the current, aided if necessary, by a pair of eighteen-foot oars. Moving up-stream, the boat was propelled by "setting poles," twelve or thirteen feet long, and shod with iron. On the thwarts was laid on each side a plank twelve inches wide. Along these walking-boards two members of the usual crew of three, starting at the forward end, with poles on the river bottom, the tops set against their shoulders, walked to the stern, pushing the boat forward, and rapidly returning to repeat the process. The captain steered, using an oar on a pivot to hold the boat from going back with

1 We are indebted for the description of the Durham Boats to Navigation on the Upper Delaware, by J. A. Anderson. 
the current, or when necessary, pushing it forward by "setting" with a pole in the short distance which the length of the stern deck permitted. The steering oar was thirty three feet long, with a blade twelve inches in width. In addition to this equipment, each boat carried a mast with two sails, and with a fair wind could outsail all other craft on the river. The lack of a center-board, as well as the great proportionate length, prevented sailing to windward, but with two men to steer, it was possible to sail up the rapids with a fair wind.

The Durham boat was generally painted black, probably with due regard to the effect of its usual inky cargo on any other color! The boat-horn was a prominent feature of the equipment. Accommodations for the crew were of the most primitive character, and the furniture carried of the simplest. A large iron pot, with a side hole near the bottom for draught, served as a cook-stove, with pieces of flat iron to hold the pan. There was a coffee pot, a water bucket, and for each man a tin cup, plate, knife, and possibly a fork, with the unfailing gallon jug of whiskey for all. An old boatman has stated that drinks were only taken at certain places on the river. The men slept on "barn feathers" or straw, in the forward end under the deck, dignified by the name of "cabin."

The men who formed the crews of these romantic boats were a hardy lot. Their labor was severe at times, but they toiled through the livelong day with the poles at their muscular shoulders, forcing their way against a rapid current at the rate of from one to two miles an hour. The boats drew but twenty inches of water when loaded with fifteen tons of iron, and in appearance were not unlike the keel boats of the western rivers. Jest and song beguiled the weary hours of the long journey, and it was usual for several of the boats to go in company, sometimes as many as twenty-five at once dotting the sweeps of the river under 
sail in a fair breeze, when the effect was extremely picturesque. The Durham boat moved so easily through the water that she left the run aft in passing almost as still as she found it. Clawson's Tavern, on Water Street above Vine, was the popular resort of the Durham boatmen, ${ }^{1}$ who made fast their craft below this point, and spent here the interval before their return.

The Durham boat figures in an important incident of the Revolution, and was evidently known favorably to General Washington who, when preparing to abandon the line on the Hudson, and make his way across the Jerseys, wrote from New Brunswick ordering boats to be collected for the expected crossing at Trenton. Trevelyan states ${ }^{2}$ that he made a point of securing the Durham boats, and his order mentions the fact that one of these could carry a regiment -a pitiful intimation of the depleted state of the American army. These boats were again brought into requisition at McKonkey's Ferry for the attack upon Trenton, and about forty were on the Delaware at the time. The form of the boat as shown on the Trenton Battle Monument is more nearly that of the Durham boat than those drawn in E. Leutz's picture of the crossing. ${ }^{3}$ Besides being active and hardy to an unusual degree, these boatmen were fearless, sportive and trustworthy. One authority states that their faithfulness became a proverb, and that their stern honesty was such that no single instance of defalcation is known in the heavy remittances which they carried. ${ }^{4}$

During the War of the Revolution, shot and shell were made at Durham in large quantities. ${ }^{5}$. In the year 1789 twelve slaves escaped from Durham Furnace to the Brit-

1 A. Ritter, Philadelphia and her Merchants.

2 G. M. Trevelyan, History of the American Revolution, II, p. 2 r. Washington to Col. Hampton, I776.

3 J. A. Anderson, Navigation of the Upper Delaware.

${ }^{4} \mathrm{~J}$. A. Anderson, Ibid.

5 Ringwalt, Transportation Systems in the United States. 


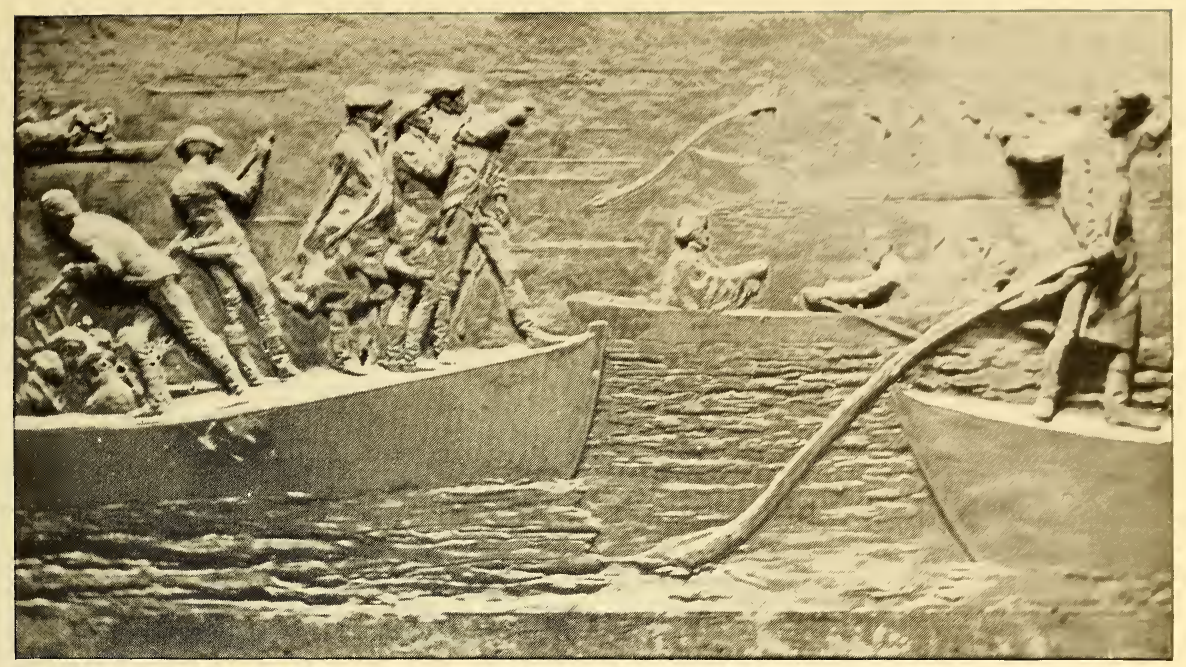

Durham Boats. Continental Army crossing the Delaware. Bronze Relief by Thomas Eakins. Trenton Battle Monument.

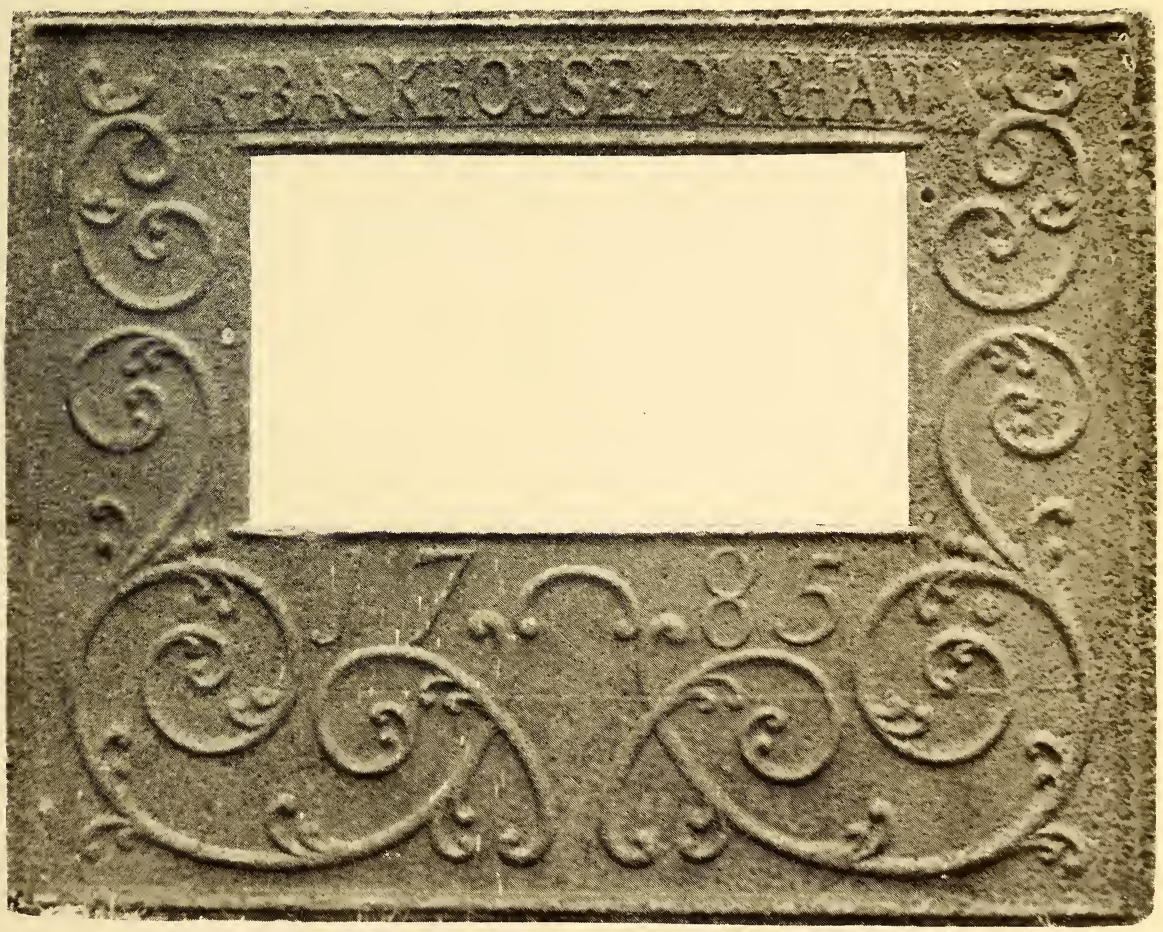

Stoveplate door, Durham Furnace. Owned by Mrs. Arthur Maginnis. Swiftwater. 

ish lines. ${ }^{1}$ During this year, over two tons of shot and shell shipped to the Continental army in November alone were valued at $£ 25$ per ton, and the total for the year was $£$ I,076, Is. 2.I/2d. Three and nine pound shot were cast, and some double-headed. The shell weighed from twenty to sixty or more pounds each. A quantity of these were left until so late as 1806 , piled against the old furnace walls. Specimens of them may be seen in the Bucks County Historical Society's collection at Doylestown, Pennsylvania.

The partnership of 1726 , with which our history began, and of which on March 4, I727, Griffith Owen and Samuel Powel became trustees, was to continue, according to the agreement, for fifty one years. Before that period of time had expired, the property had been freed of the trust, and none of the original owners remained, having been removed by death, failure, or the sale of their interests. An amicable Deed of Partition was therefore executed, December I4, I 773, and the property, which had been added to, then comprised over eight thousand acres, including the entire township of Durham and one tier of farms in Northampton County. Included in the tract which thus fell to Joseph Galloway and his wife Grace, the daughter of Lawrence Growden, were the eight hundred and eighty nine acres and forty eight perches which practically constitute the Durham furnace of today. Joseph Galloway thus became the first individual owner of the furnace.

At this period, for five years, the furnace was leased to George Taylor, for two hundred and fifty pounds per annum. Taylor was born in Ireland, came to Pennsylvania as a "Redemptioner," and at one time was a "filler" at Durham furnace, which he finally leased and conducted alone. At the summit of his career, he had the honor of signing his name to the Declaration of Independence.

1 Pearce, Annals of Luzerne. 
While lessee of Durham, he cast stoves bearing the inscription "Durham Furnace, I774." A plate of one of these stoves, thus inscribed, is fastened against one of the walls of the Post Office at Easton. George Taylor died in I78I.

The disturbances of the Revolution rendered business very uncertain. Upon the charge of treason against Galloway, who allied himself with the British, his property was confiscated and sold by the Commissioner of Forfeited Estates and confirmed by the Council, to Richard Backhouse, September 14, I779, for the sum of $£$ I $2,800 .{ }^{1}$ The latter appears for some time previous to have had an offcial connection with the works, and was a Justice of the Peace. His account books have been quoted.

The period of the Revolution finds several well known names in the history of the country directly connected with this old furnace. There is a long list of the forges which Durham supplied with pig-iron for manufacturing purposes. Besides George Taylor, the name of George Ross, another signer, meets us at Bloomsbury Forge, New Jersey, near by, where much material was sent; Ross was a prominent owner. James Morgan, of an old Welsh family of the name, "Iron master," was an owner of Durham before the partition. His home was near the banks of Durham Creek, not more than three quarters of a mile from the works, where he would appear to have been actively employed. Here his son Daniel was born in 1736 , destined to become one of the distinguished generals of the Revolution. As a boy, Daniel assisted his father at the furnace, and tradition even makes him a charcoal-burner. When the war broke out, Daniel enlisted and his later career is matter of history. It is interesting to note that the General's father, James Morgan (who may or may not have held an interest in Valley Forge as well), in I762, which is remarked as a year of unusual building

1 Colonial Records, Vol. XII, p. ro4. 
activity in the Colonial period, built a beautifully simple, but plain and substantial house for himself at Lower Providence, Montgomery County, in that neighborhood, which he called "Mill Grove." The date-stone in the gable remains, and the house is the shrine to which pilgrims come to revere the memory of a later distinguished resident, John James La Forest Audubon, the great ornithologist. ${ }^{1}$

At one period after the death of James Logan, the works were operated under the name of William Logan and Company. Part owners at times more or less briefly, are Richard Peters, Edward Shippen, Israel Pemberton, and Hon. James Hamilton, who for a time held an interest when Lieutenant Governor, in I749. Lawrence Growden was a prominent owner; his daughter, Mrs. Joseph Galloway, died in 1782 . Her trustees in 1803 succeeded in a suit against the heirs of Richard Backhouse (died I793), who were dispossessed because of proof that Joseph Galloway, who devised his property to his daughter E. Roberts of London, held the property only in right of his wife, Grace Growden. An Act of Legislature in I 808 appropriated $\$ 4$ I 5 to reimburse Mary, widow of R. Backhouse, to compensate her for cost of defending herself in the proceedings.

Durham remained in active operation, with occasional periods of suspension during the hard times of the war and after, until I794, when it finally "blew out." In I 829 the old furnace was demolished to make room for a grist mill. Just before the Civil War two new furnaces were built, using anthracite coal, and these in turn made way for a large new furnace in 1874 .

\section{Amelia Mott Gummere.}

1 Thomas, brother of James Morgan, at one time kept an inn here. In I77r, the property was sold to Rowland Evans. It was bought in $177^{6}$ by John Penn, and after several transfers, was in 1789 sold by Augustine Prevost to John Audubon, the Admiral, and father of the famous ornithologist. (See Eberlein and Lippincott, "Colonial Homes of Philadelphia and its Neighborhood," p. 199.) 


\section{Philadelphia, Later Berks County.}

Though this forge was of undoubted importance among the primitive iron works, we do not find much data relating to it in the early records we have been able to consult. The date of its construction seems to have been I 729 , and on a map dated 1792 and dedicated to Thomas Mifflin, Governor. Spring Forge is indicated on the Manatawny Creek, just on the dividing line of Amity and District townships.

It seems to have been the personal financial venture of Anthony Morris of Philadelphia, but there is no indication that he specially managed the works in the capacity of director or iron-master. His interest in the development of the iron industry was so keen, and his help of such importance that it may be well to sketch briefly the life of this typical colonial citizen.

Anthony Morris, 3 rd, the son of Anthony Morris, 2nd, and Mary Jones his wife, was born in London, March I6, I68I, and brought by his parents to America when he was about ten months old. He was destined to be an important member of the infant colony. His youthful education was probably under the guidance of Enoch Flower, master of a public school which the early Friends had founded.

In the simple annals of the day we are told that he was at the age of fourteen apprenticed for a period of seven years to learn the "art and mistery of brewing." In the indenture, still extant, he promises his master and mistress that "he will well and faithfully serve them, their secrets 
he shall keep, their commands lawful and honest every word he shall obey, their hurt or damage he shall not contrive or do, nor suffer to be done; and the said master and mistress, beside teaching all the mistery and art of brewing, promise that he shall be allowed sufficient meat, drink, washing, lodging, and mending of his linen and woolen cloathes, and that they shall not put him to drive the dray or cart, carrying of casks, grinding at the hand-mill, or such like slavish work not fit for an apprentice of his degree."

Young Anthony "served his time" to such good purpose that at the age of twenty-five he became part owner of the "brew-house and utensils" of his father, building up a business which has since been carried on by the lineal descendants of these pioneer brewers.

At twenty-three he married Phoebe Guest, whose parents were among the settlers who lived for a time in caves in the bank of the Delaware until. they could build houses to dwell in.

Before he was thirty he was elected to the common council of the infant city, an office of much greater dignity than now, the tenure of which was for life. His biographer says of him, "he was a man of good repute, carriage, bearing, and estimation and filled many offices with credit." $\mathrm{He}$ represented his city in the Provincial Assembly, was Associate Justice of the local court and was one of the committee who drew up an address to Governor Gordon on his arrival in Philadelphia.

At the age of forty, then, Anthony Morris might have been described as a "man of parts." With a goodly for: tune acquired in the brewing house, a broad outlook as a foremost citizen and enterprising business man, no doubt he had a keen eye to the possibility of developing large 
fortunes through the rich natural resources of this favored colony.

We can fancy with what interest he followed the venture of Thomas Rutter and Thomas Potts when they opened up the iron mines in the trackless forest which bordered the Schuylkill and its tributaries, and we are not surprised to find him furnishing the capital which should give their enterprise success. He was part owner of Colebrookdale Furnace in Berks county, one of the fourteen founders of Durham Furnace, Bucks county, also a shareholder in Pool and other forges.

No family is more closely connected with the early history of Pennsylvania than that of Morris, and none has been more valued for its business ability and its sturdy and loyal citizenship. It is said that the Anthony Morris now living is the eighteenth of the name.

Mary E. Mumford. 


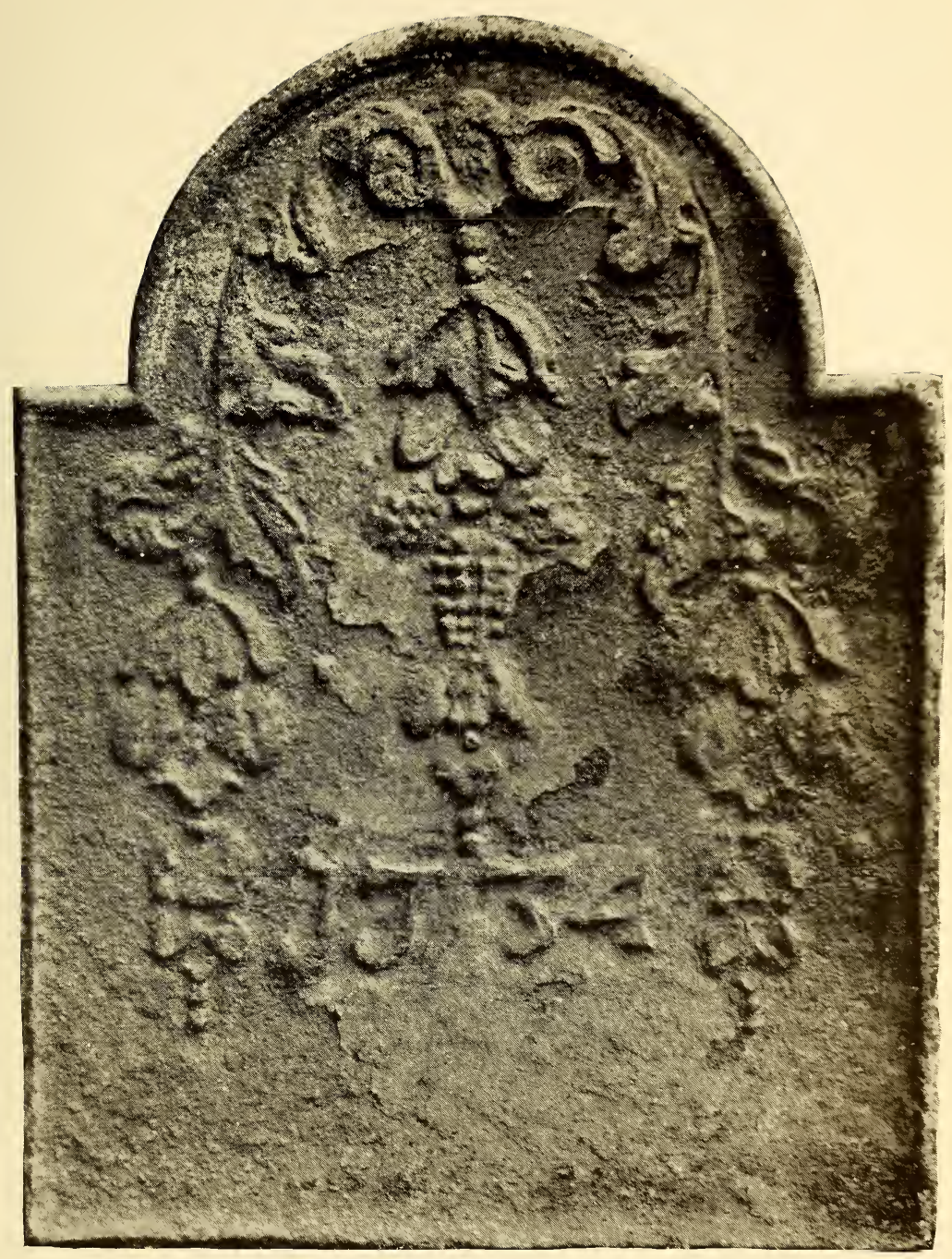

Fireback, 1734. Found in West Chester by Dr. W'm. T. Sharpless. Design somewhat similar to that of fireback in residence of Mr. Joseph Ury Crawford, Ury, Foxchase. 




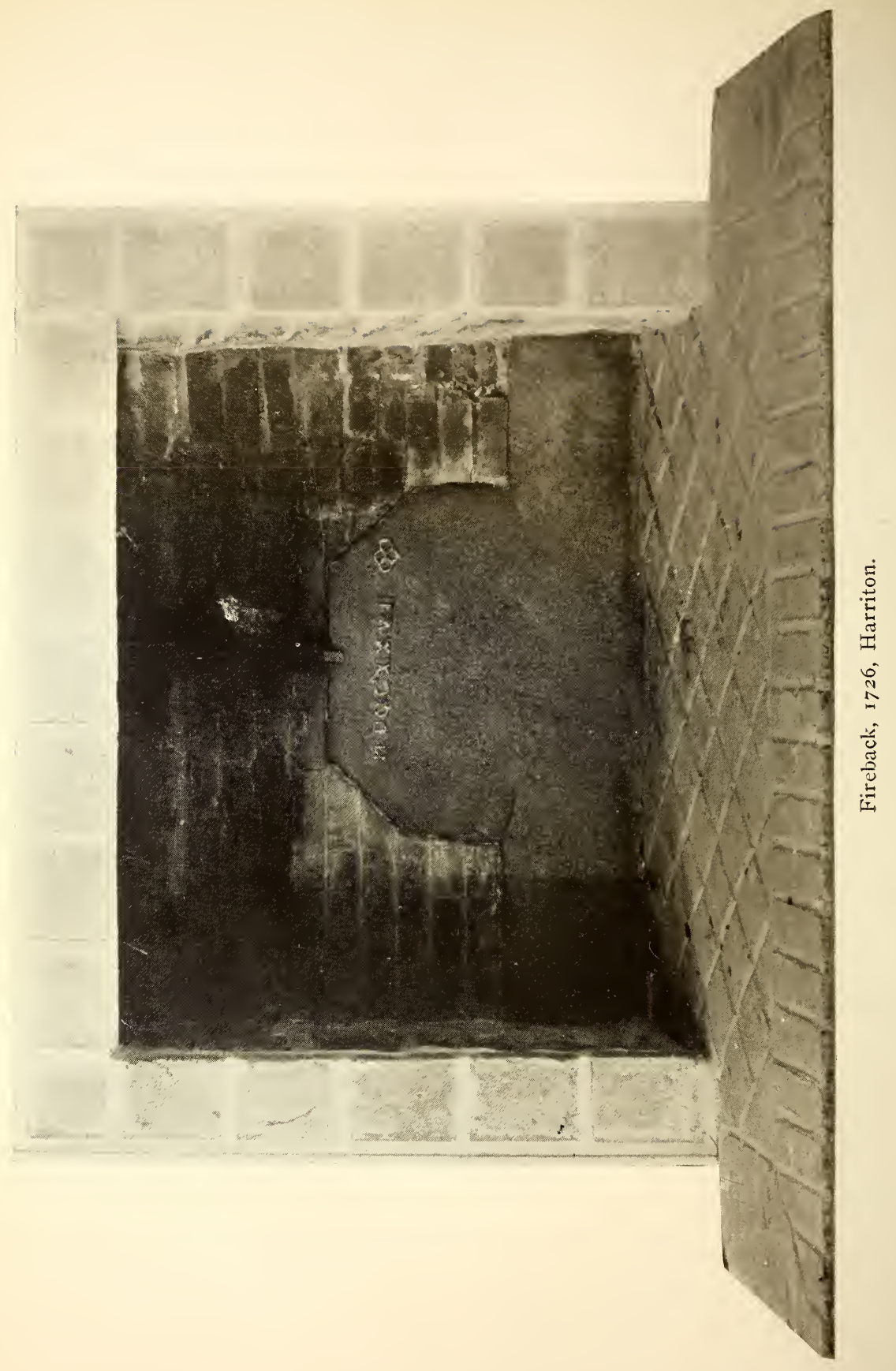




\section{EARLY FIREBACKS.}

One of the most interesting firebacks in Pennsylvania is in the ancient fireplace of the entrance hall at Harriton. Bryn Mawr. The house was built in 1704 by Rowland Ellis, one of the settlers of the Welsh Tract, and has since fortunately undergone very little alteration. In I 7 I 9 Richard Harrison, son-in-law of Isaac Norris, came from Maryland and bought the estate. Upon the marriage of Hannah Harrison, his daughter, to Charles Thomson, the distinguished Secretary of the Continental Congress, the latter, in 1774, became master of Harriton, which has since remained in the possession of his wife's relatives, in the Morris line.

The fireback bears the date MDCCXXVI, with a very interesting design somewhat resembling a true lover's knot at the side. There is as yet uncertainty as to its origin. If it was brought from Maryland, it probably came with Richard Harrison, fifteen years after the house was built. Its rough form would indicate an early experiment in the moulding. Several of the owners of the furnace at Durham were relatives or intimate friends of the Harrisons, and it is possibly one of the first made at that place. It is, at all events, noteworthy, as among the most curious specimens which have so far been found in Pennsylvania.

Another fireback bearing date I734, was brought to our notice by Dr. William T. Sharpless, of West Chester. It resembles in shape and general decoration, the Durham fireback, of I728, at Stenton. We cannot, however, say that it was made at Durham furnace. 
Before

I730

\section{PINE FORGE.}

\section{Philadelphia County, Later Berks.}

While the exact date of the construction of Pine Forge is not known, it was, no doubt, among the earliest of those erected in the Manatawny district. The tradition persists in the Rutter family that here the pioneer iron-master Thomas Rutter made himself a home and laid out an estate. The original patent of $\mathrm{W}^{\mathrm{m}}$. Penn conveying these lands to Thomas Rutter is preserved among the archives of the family. The present owner of the property says: "It is supposed that Thomas Rutter ( ${ }^{\text {st }}$ ) must have come from Warwickshire, England, as the many old homes on the estate were named for Warwickshire places, as Warwick, Stowe, Coventry, Stratford, and Colebrookdale. Also that he chose this grant of land because of its resemblance to the Warwickshire district, a similarity often noticed by our friends. Another tradition we cherish is that he crossed the ocean on the good ship 'Amity' - and named the pretty little village nearest us 'Amityville.'" Thomas Potts, who was associated with Rutter in the iron industry, had an interest in the Forge, and carried on the business, while his son John in his will, I 767 , gives the following description of the acres accumulated under his management.

"Item: whereas I stand seized in fee simple of a forge in the County of Berks by the name of Pine Forge, with the following tract of land thereunto belonging; viz. 300 acres which I purchased from Mary Rees, I 50 acres which I bought from Seeny Savage, 200 acres which I bought from John Jones, I 50 which I bought from Marcus Hulings Jr. 



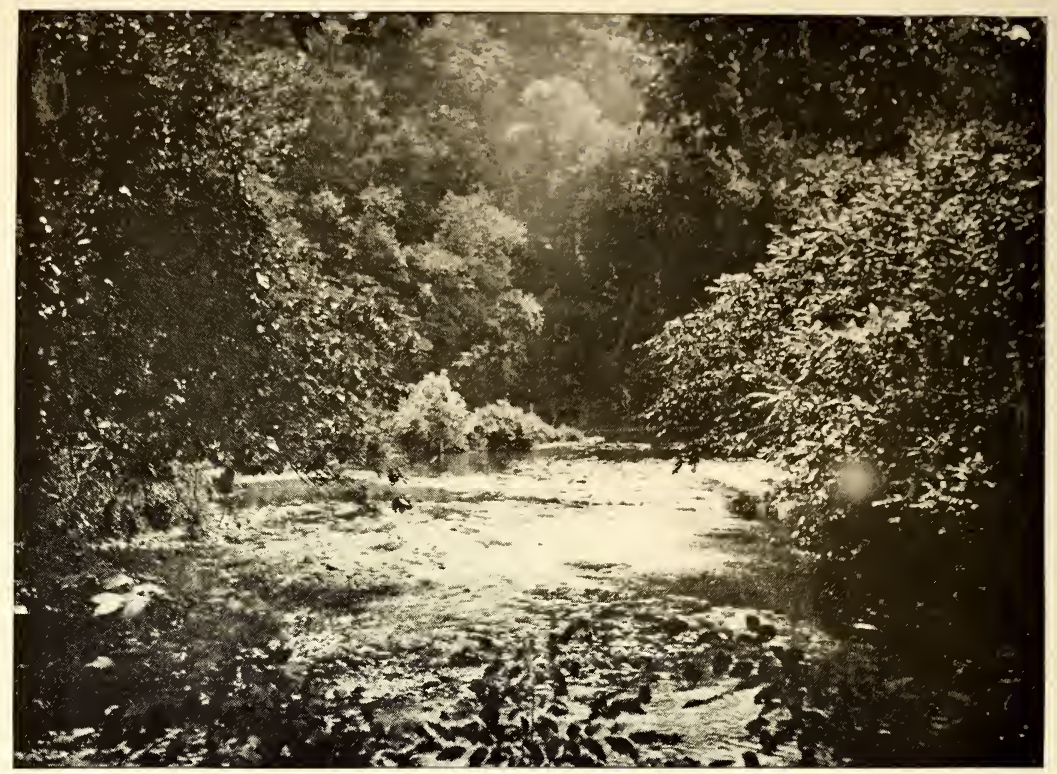

The stream at Pine Forge, named by the Indians "Manatawny," the place where we drink.

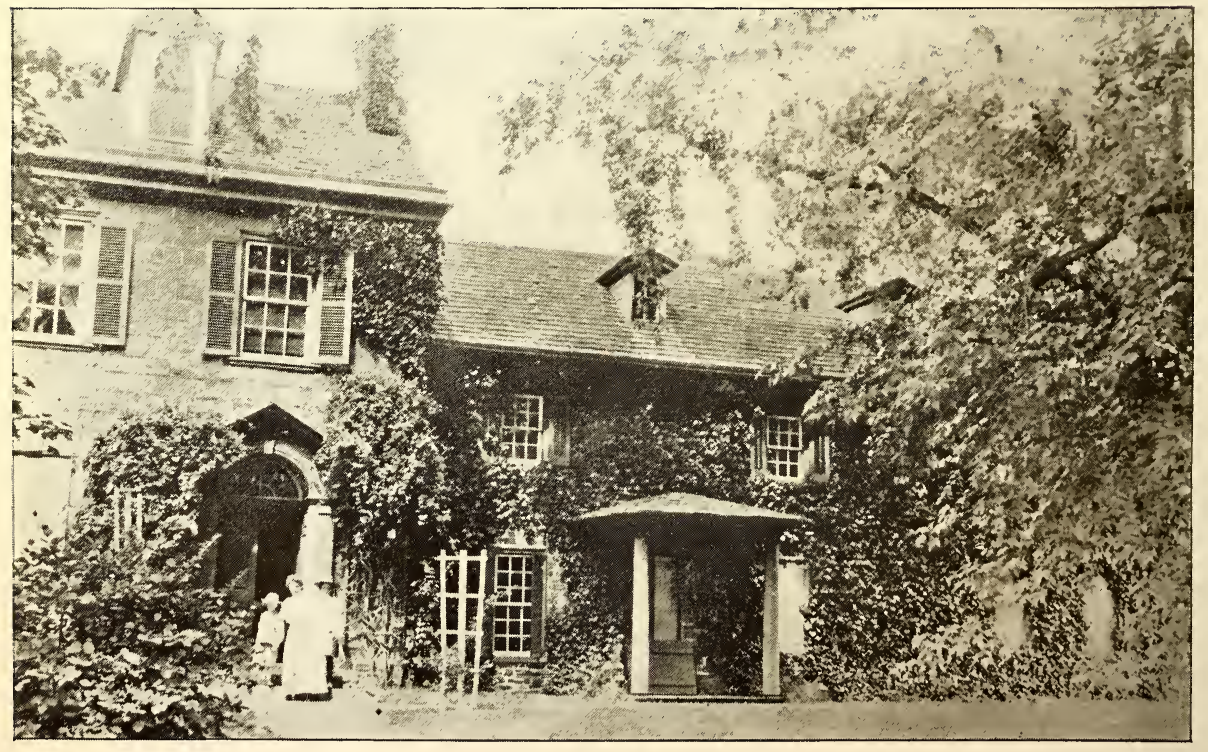

Mansion, Pine Forge. 
I 25 acres which I bought from the Trustees of the Loan Office, and Ioo acres whereon the said house now stands, containing in the whole 1280 acres of land."

If he had an idea of establishing a great barony after the custom of his English forbears his plan was not realized, for after his death the lands were divided and sold in separate lots. The Forge with three hundred and fifty acres surrounding it was bought by David Potts for the sum of two thousand pounds. In the previous year he had married his cousin Anna, daughter of John, and the newly wedded pair settled at Pine and lived there until they died. Their heirs were two daughters, and the property was again sold, August, I 783 , this time to David Rutter, the great-grandson of both Thomas Rutter and Thomas Potts. He married about this time his cousin, a daughter of John Potts the royalist. David repaired and partially rebuilt the house, and carried on the works until his death in I $\delta$ I 5 . It is a singular fact that in this country where no entail exists, the old demesne at Pine (with the exception of about sixty years, I 844 to 1907 , when it was in possession of the Bailey family), has been owned and occupied by the descendants of the original purchaser. Constant intermarriage of the families has brought this about, the latest occurring in I9I3, when the son of the present owner married a direct descendant of Margaret Rutter, who was born at Pine, October I 5, I 790, one hundred and twentythree years ago.

There is every evidence that the group of early forges and furnaces including Pine, Pool, Colebrookdale, Warwick had a general interchange in their business affairs. Their old day-books and ledgers in the possession of exGovernor Pennypacker, at Schwenksville, Pa., show that the owners of these plants were almost identical.

In one of the Pine ledgers we find a statement of the 
output of Pool Forge from May to November, I734, to be one hundred and twenty tons of bar iron distributed among the following men: Capt. Atwood, Alex Woodropp, George Mifling, Thomas Yorke, Anthony Morris, Nathaniel French, John Leacock; while the owners of Pine Forge about the same date are Thomas Potts, Geo. Boone, John Leacock, George Mifflin, Alex Woodropp, Edward Farmer, $\mathrm{W}^{\mathrm{m}}$. Atwood, Morris Morris.

$\mathrm{W}^{\mathrm{m}}$. Bird at this time, $\mathrm{I} 733$, was cutting wood for the use of Pine Forge at two shillings ninepence a day. Ten years later, I743, we find him renting one eighth of Pine Forge at forty pounds per annum - the modest beginnings of one who later became an important factor in the iron industry.

Thomas Yorke, after a few active years in the forge country, settled in Germantown where he became a sort of factor or agent for the iron interests. In an entry in his day book, February 7, I748, he speaks of his one third interest in Pool Forge as yielding $625 / 100$ tons of "Barr Iron," and his yield from $1 / 3$ of Pine Forge as 6 tons.

His business transactions for the Pine Forge Colony, aside from his iron commissions, cover a wide field of domestic needs. Under date of January 3, I 752 , he charges the estate of Thomas Potts with:

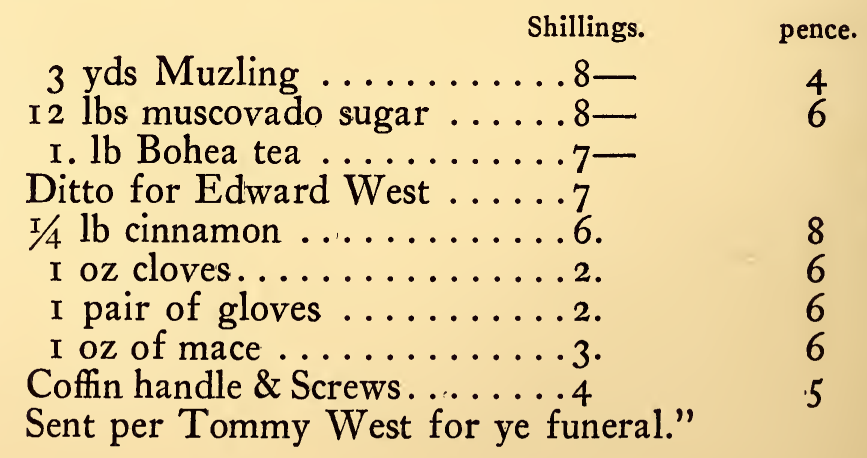




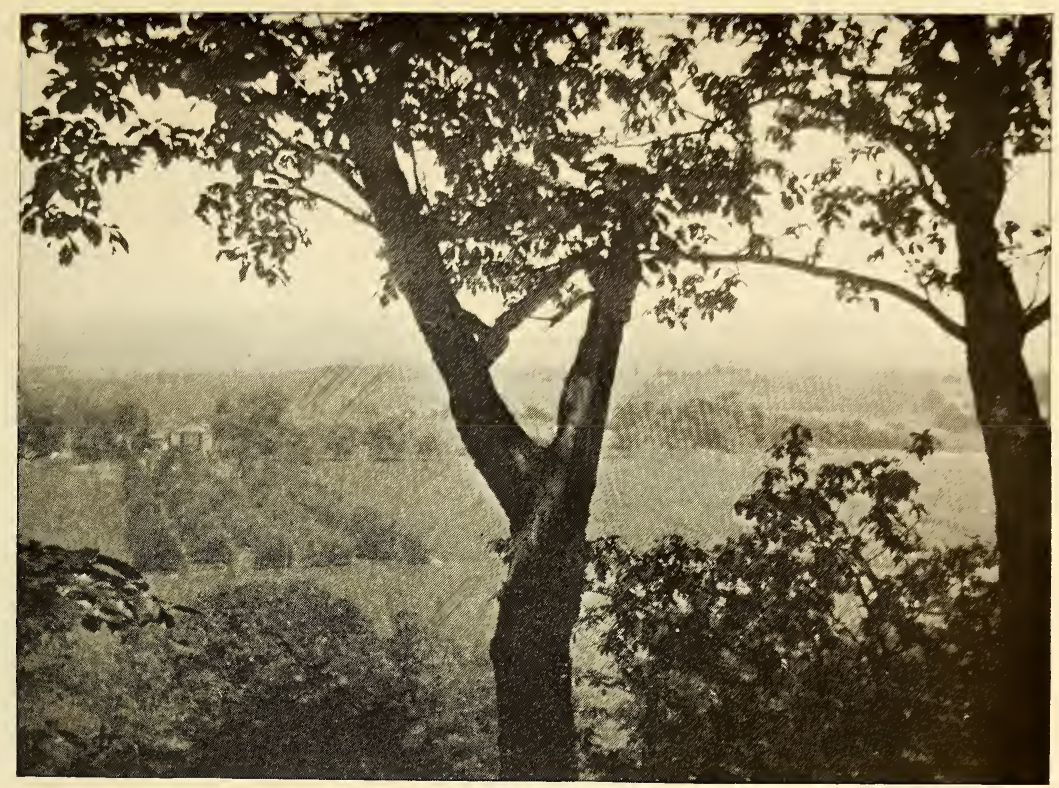

Meadows of the Manatawny, Pine Forge.

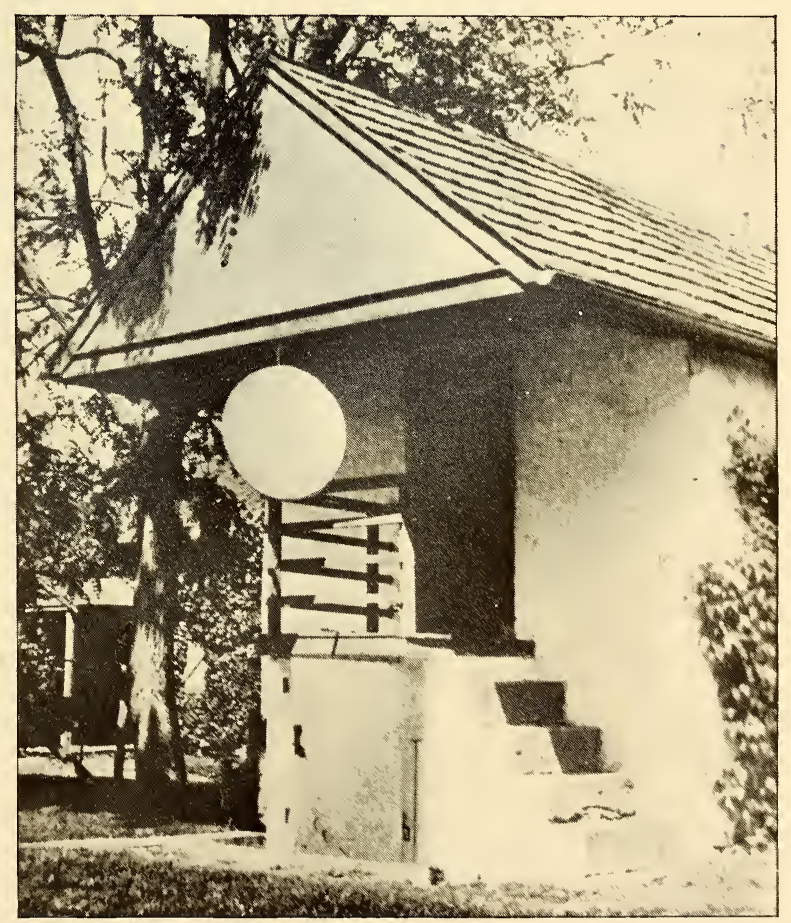

Oldest building at Pine Forge, showing gong. 

$\mathrm{He}$ also charges shoes and gloves and other articles bought for "Miss Fanny" and her bills for board in Germantown are also paid by him. In May, I753, he notes "paid for a Quarters' Schooling of your sons Samuel and Johnny at G. Academy 2£. Is."

The management of the old forges was patriarchal in its character. The Grist mill, saw mill, and village store were all under the control of the Company. One could reconstruct the domestic life of the colonial period from the old accounts preserved in day book and ledger. One learns the cost of foods and fabrics, and notes the frequent use of strong drinks, especially of rum. One finds what wages were earned, and what was spent for daily needs-down to the item of "a bleeding-one shilling." The region of the old Pine Forge is teeming with the human interests of an earlier day.

Mary E. Mumford. 


\section{Montgomery County.}

This forge, on Perkiomen Creek, twenty miles north of Norristown, was built in 1733 by Thomas Maybury. "The foliage covering the rocky hills north and west of Perkiomen Creek, and the narrow crooked lane that led from the highway around the base of the hills," to the forge, are responsible for the attractive name.

The earliest settler in Marlborough township was Thomas Maybury, who bought in $173^{\circ}$ a tract of land, twelve hundred and forty acres, on which he erected this forge, which before 1747 was supplied with pig iron from Durham furnace. He married a descendant of the first Thomas Rutter.

Green Lane Forge was owned by Rev. George Michael Weiss before 1763. The workmen here, at one time, were chiefly negro slaves. "For many years the best blooms in the market were produced here. In those days the country blacksmith purchased his bar iron at the forge, and converted it into the hardware used in building houses, from the wrought nails in the floors, to the hinges, and latches of the doors. Iron was a commodity that eighty years ago was fashioned into a thousand forms by the village smith; forms which are now produced by the foundry, and sold at the village store." The transition has changed the face of affairs at this village. The forge has long since gone into decay; "the old water wheel, the huge bellows, the ore crushers, the cone-like charcoal kilns, the famous weekly teamsters who made their trips to town and back; - the huntsman and his hounds; - these are all gone; -and Green Lane is an ordinary railroad village." 1

${ }^{1} \mathrm{~T}$. W. Bean, History of Montgomery County, p. 721. 


\section{THE DAVID JONES FURNACE.}

\section{LANCASTER COUNTY.}

David Jones, who built one of the first furnaces of $\mathrm{Co}$ lonial Days in eastern Pennsylvania, emigrated from Merionethshire in Wales in I72I and settled upon the Welsh reservation at Radnor in Chester county, Pennsylvania, where that clannish people, to use their own language, "desired to be by themselves, for no other reason or purpose but that they might live together as a civil society, to endeavor to decide all controversies and debates amongst themselves in a Gospel order, and not to entangle themselves with laws in an unknown tongue, and also to preserve their language that they might ever keep correspondence. with their friends in the land of their nativity."

David Jones with many of his countrymen removed from Radnor in 1730 to the valley of the Conestoga, in Caernarvon township, Lancaster county, where he became an extensive land owner and iron-master, and where there are old mines which still bear his name. The site of the old Jones furnaces, or "Jones's mine holes" as they were called in the quaint language of that day, is most picturesque. In this place his three sons were born: John Jonathan and Caleb. John was a major of the committee of safety in I774 and a major in Grubb's battalion of militia. Caleb was a justice of the Peace. Jonathan Jones was born in 1738 . He was appointed a captain in the regular Continental Army, October, I775-promoted to rank of major after active service in Canada in 1776, and to lieutenant-colonel of his regiment, March, I777. His constitution was so shattered by the hardships and ex- 
posure of the campaign against Canada, that he was obliged to return home in the winter of $1776-77$. He rejoined the regiment in the spring of 1777 , the command of which devolved upon him, after the resignation of Col. James Irvine. Increasing ill-health obliged him to resign his commission in the latter part of July. In December, I 778, he was a member of the General Assembly of Pennsylvania. His health continued to decline, and he was shortly afterwards stricken with paralysis, of which he died in September, I782, at the early age of forty-four. He was buried in the Bangor churchyard at Churchtown. His family had been wardens and vestrymen of this church from its earliest foundation.

Katharine Jones Wallace. 


\section{WARWICK FURNACE.}

\section{Chester County.}

Samuel Nutt, who died in 1737 , directed in his will that his wife, Anna, "shall have one hundred and twenty acres of land on the South branch of French Creek, on which to build a furnace, and also leave to cut as much timber on lands adjacent as shall suffice to erect the same." ${ }_{1}$ This furnace, called Warwick, was begun the same year, and became one of the greatest iron works of Pennsylvania. When in blast, from five to six thousand cords of wood were used there annually, the product of about two hundred and forty acres of woodland. The cost of the large bellows, run by an immense water wheel, was nearly two hundred pounds. Twenty-five tons of iron a week was the usual product. In an "Account Book of Warwick Furnace" we find sundry entries, such as "I759 April 23 -Paid the County Tax, four shillings." "Provincial Tax-four shillings." "Potts and Rutter, to loads pigg iron from 27th April to Ioth May I759, I I tun." "To Sarum Forge, from 4th April to 3 rd May I759, I3 tuns and I 5 lbs. pigg iron."

This furnace produced both pig iron and castings, the latter being stoves, pots, kettles, andirons, smoothing irons, clock weights and other articles.

William Branson ${ }^{3}$ had been a partner with Samuel Nutt for years. This partnership was continued at Warwick by Anna Nutt and her son-in-law, who was also her step-

1 Potts Memorial, 53.

2 Collections of the Hon. S. W. Pennypacker.

3 See Coventry Forge. 
son, Samuel Nutt, Jr., until the death of the latter in I739, the value of the property having in the meantime greatly increased. This is the period when the partnership was dissolved, Branson taking Reading alone, and Warwick going into the care of the firm trading as Anna Nutt and Company, with the addition of Robert Grace, who married the young widow of Samuel Nutt, Jr., in I740. The name of Nutt then became extinct.

Next year, the new partners brought suit against Branson, charging him with taking iron ore from their property, while Branson, by John Kinsey, brought a counter suit for a suitable accounting for the time "when they were baliffs to him, the said W. B." They made the defense that they had never been his bailiffs, and John Tench Francis, their attorney, appears to have settled the matter finally, for no other proceedings are traceable.

War was declared with Spain in 1739 , and in response to a call for enlistments, which Governor Thomas in his proclamation of April 14, I740, called: "a Glorious undertaking," many of the indentured servants at the furnaces and in other employ departed unceremoniously. Since the Governor did not discountenance this proceeding, the Assembly could only endeavor to reimburse the masters, and on June 4, I74I, there is record of a petition from Anna Nutt and Co. for several hundred pounds damages because of the enlistment of ten servants at one time, some of them colliers, whose abrupt departure had put a stop to the works. ${ }^{1}$

The name of Robert Grace has an additional interest as the friend of Benjamin Franklin and the first manufacturer of the noted Franklin stoves. Born in 1709 , of fine Irish stock, Grace was brought up in the house of his grandmother, whose second husband was Hugh Lowden. The house was on the north side of High Street, below Second,

1 Futhey \& Cope, History of Chester County, p. 49. 
then the most eligible part of the city. The Town Hall or Court House stood in the center of the street, nearly opposite, where all royal or colonial proclamations were read to the people from the balcony. When Grace was seventeen, this house became his property, and here the warm and lifelong friendship with Franklin was begun. Franklin, in his Autobiography, describes Grace as a young man of some fortune, generous, lively, witty, fond of epigrams but more fond of his friends. In the well-appointed rooms of this house the Junto met, and the first public library in America was organized and maintained for ten years. In the inventory of furnishings the parlor has: " $\mathrm{I}-8$ day clock, 2 black walnut tables, carpet and looking glass, writing desk and spice box. 20 leather chairs, couch and Squabb, I Skreen, I great Bible and stand, 2 pr. dogs, fire shovel, Tongs, Poker, bellows and fender. I Jappanned Montiff, ${ }^{1}$ a lamp, glass and Earthernware." 2

Franklin's gratitude to Grace must be recorded here. Franklin and Meredith, his partner (about I729) had been sued for £roo. "In this distress," he says, "two friends, whose kindness I never have forgotten, nor ever shall forget while I can remember anything, came to me separately, unknown to each, and without any application from me offered each of them to advance me all the money that should be necessary to enable me to take the whole business upon myself,-but they did not like my continu. ing the partnership with Meredith. . . . These two friends were William Coleman and Robert Grace."

Franklin mentions, in the codicil to his will, that his reason for leaving $£ 2000$ sterling to the cities of Boston and Philadelphia for the purpose of setting up young married artificers in business was because "I was assisted to set up my business in Philadelphia by kind loans of money

1 Query, were monteiths ever japanned?

2 Potts Memorial. 
from two friends there, which was the foundation of my fortune and of all the utility in life that may be ascribed to me."1

The Autobiography of Franklin has the following entry: "... Having in 1742 invented an open fireplace for the better warming of rooms, and at the same time saving fuel, as the fresh air admitted was warmed in entering, I made a present of the model to Robert Grace, one of my early friends, who having an iron furnace, found the casting of the plates for these stoves a profitable thing, as they were growing in demand."

These stoves were manufactured at Warwick, and had the words "Warwick Furnace" cast on the front plate in large letters. ${ }^{3}$ They were very popular with the well-to-do for the next fifty years, and some fine examples of them are still extant. Their manufacture was evidently remunerative, as also their final sale, if one may judge from an "Account with Benjamin Franklin," in a Ledger of Warwick Furnace."

" 1747

Oct. 5 To one Tun Fireplaces pr

I 75 I July I 5 To two tonn Fire Places

Henry Snyder.

Aug. 3. To one tonn Fire places pr.

pr. Owen Richards.

Andrew Sping.

$\begin{array}{llllll} & 6 & \text { " } & \text { “ } & \text { “ } & \text { ditto pr. Mathias Brooks. } \\ \text { “ } & \text { 19 } & \text { " } & \text { “ } & \text { “ } & \text { pr. Wm. Ball's team } \\ \text { " } & 20 & \text { " } & \text { " } & \text { per Saml. Cryble. }\end{array}$

Oct. 26, To 4 plates of ye Neweste Fashion Stove I 5-4-6

1752 Nov. 4. To 22 Fireplace plates

per Owen Rodgers."

1 Potts Memorial.

2 Collections of the Hon. S. W. Pennypacker.

' See Sequence of Franklin Fireplaces. 


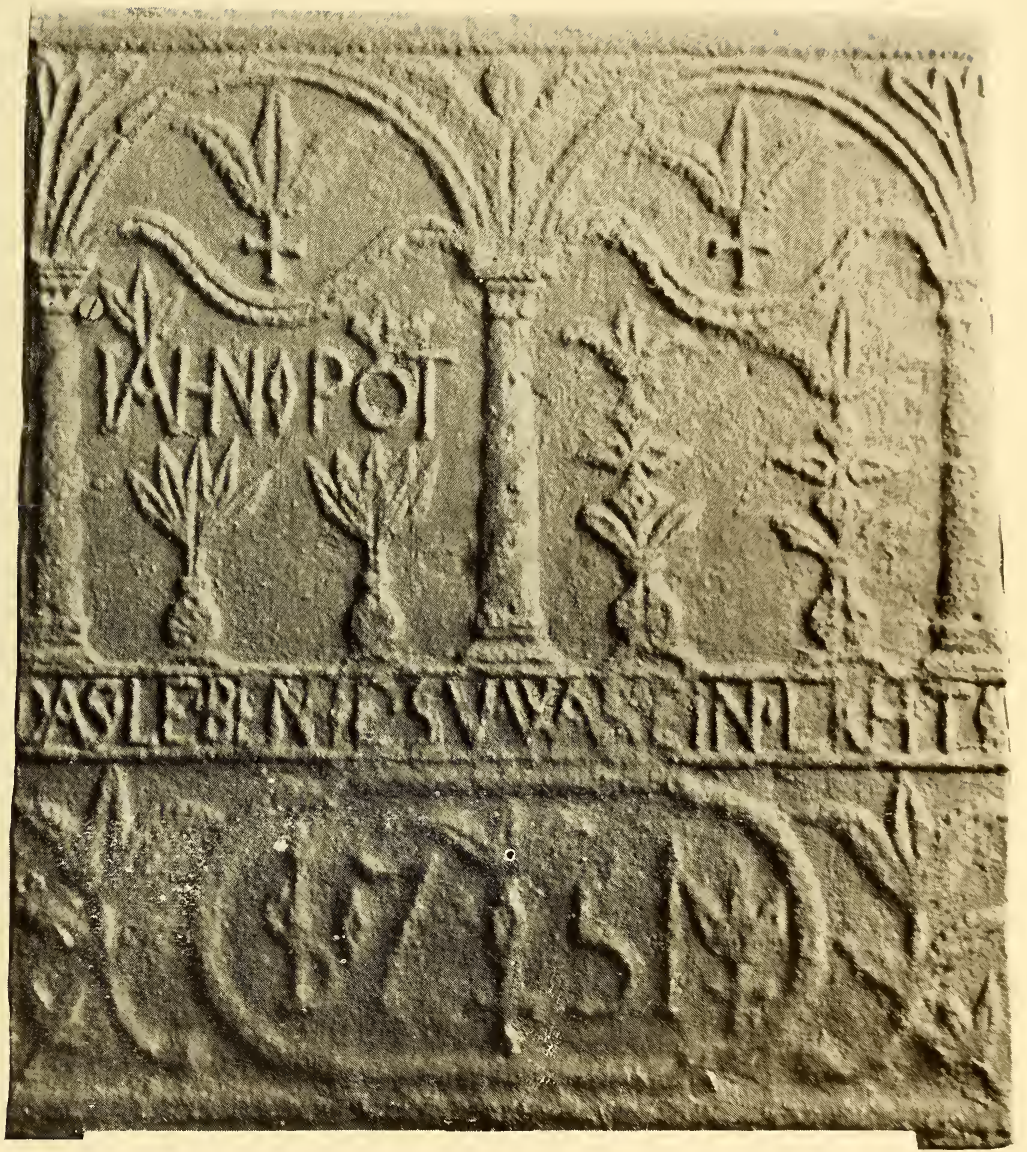

Stoveplate, John Potts, I757. "The life of Jesus what a light." 

Christopher Sauer was one of the first agents for the sale of these stoves.

Towards the close of the eighteenth century Franklin stoves were much used in Paris. One of the French ministers was asked whether he had, as yet, put them into his reception rooms. "No," he replied, "for the English Ambassador would not then consent to warm himself at my fire."1 In the eulogy pronounced by Dr. William Smith, first Provost of the University of Pennsylvania, on the death of Dr. Franklin, he speaks of "the New Invented Pennsylvania Fireplace, the open stoves now in general use, to the comfort of thousands who, assembled round them in the wintry night, bless the name of the inventor, which they yet bear!" At the end of this book a short sequence of Franklin fireplaces will be found. It is an imperfect effort to show the earlier shape and style of these stoves, and the improvement in appearance as they were gradually made at many different furnaces.

During the Revolution, the furnace at Warwick was busily engaged in casting cannon and shell for the government. Some imperfect cannon are said to be still imbedded in the bank of French Creek. The fact that it was such an arsenal of supplies led to its choice by Washington as his headquarters after the battle of Brandywine, from the eighteenth September, I777, until the twentieth, when he crossed the Schuylkill at Parker's Ford, in attempting to interfere with Howe's march to Philadelphia. The soldiers took from the inhabitants everywhere, all the leaden clock-weights upon which they could lay their hands, in order to run them into bullets. They were replaced by iron ones, which were cast at Warwick in great numbers.

1 The American Revolution, by Sir George Otto Trevelyan, III, p. 459. 
Washington to the President of Congress.

"Wednesday Sept I 7 I 777

At Yellow Springs.

"Yesterday the enemy moved from Concord by Edgemont Road with the evident design to gain our right Flank. This obliged us to alter our position and march to this place, from whence we immediately proceed to Warwick. We Suffered much from the severe weather yesterday and last night, being unavoidably Separated from our tents and baggage."

On the I8th September, 1777 , at Warwick, Washington wrote: "The army here is so much fatigued, it is impossible I should move them this afternoon."1

("Part of the army went to Warwick Furnace on the I 7th. Warwick is 8 miles North of Yellow Springs \& 9 Miles from Schuylkill. They were joined by rest of army on day following. Warwick Furnace was a depot of manufacture of cannon-of which 60 were cast for Continental army of 12 to $18 \mathrm{lbs}$ calibre in 1776

$$
\text { From note-“"Itinerary.") }
$$

Warwick Furnace and its adjoining lands have never been out of the possession of the descendants of the elder Samuel Nutt, but are held by members of the Potts family: although in 177 I Thomas Rutter purchased therein a half interest from Samuel Potts.

Amelia M. Gummere, Augusta $M$. Longacre.

1 Washington's Itinerary, by W. S. Baker, p. 91. 
MOUNT PLEASANT FURNACE AND FORGE.

Philadelphia County, later Berks.

Situated only a mile apart, on Perkiomen Creek, about thirteen miles above Pottstown, this furnace and forge were undoubtedly under the same management, although there is little definite knowledge of their early history. Mrs. James quotes from a family document: "In I 743 Thomas Potts, Jr., gave to his son David ${ }^{1}$ one full and undivided sixth part in a certain furnace and forge commonly called Mount Pleasant, and of and in several tracts of land thereunto belonging." No remains of this old forge are now visible. David Potts, born I722, carried on the Mount Pleasant works until his death in 1752. His wife was Rebecca Rutter, granddaughter of the first Thomas. Of the frequent intermarriages in the ironmaking world of "the good old Colony times," it is surely not censorious to suggest that the background of many acres and active furnaces undoubtedly enhanced the charms of the daughters of Pennsylvania.

Little is known of the subsequent history of Mount Pleasant. "A few feet of crumbling walls" mark the site. Both furnace and forge are mentioned in a list of the iron industries, compiled by Samuel Potts, for the information of Congress when it was enacting a tariff law in I789. It must therefore have been active at that date.

1 Memorial of Thomas Potts, Jr., p. I2O. 


\section{HAY CREEK OR BIRDSBORO FORGES.}

\section{Chester County, Later Berks.}

William Bird, whose marriage is recorded in the old Swedish church register at Morlatton, now Douglassville, in $\mathrm{I} 735$, to Brigetta Hulings, daughter of Marcus Hulings, built the first of these forges in 1740 , on Hay Creek near its entrance into the Schuylkill River in Berks County. There is nothing left now of the early forges.

$\mathrm{He}$ obtained, by warrant and survey much property in this section and at his death his estate is reported to be "three messuages (dwellings) 3 forges, . . 2400 acres in Union and Robeson townships; one messuage, one iron furnace and two thousand acres in Heidelberg township." The latter is the Berkshire Furnace. We find according to Montgomery " "The Berkshire Furnace was erected by William Bird about $1760 \ldots$ the name first given to it was Roxborough."

William Bird's widow married in 1762 John Patton, whose name appears in partnership with George Ege in the running of the furnace.

We find William Bird's tombstone at Douglassville which is four miles from Birdsboro. "In memory of $\mathrm{W}^{\mathrm{m}}$ Bird Esq. who departed this life Nov. 16. I76I, aged 55 years."

The residence built by William Bird is still standing, though much depreciated in value by the encroachments of the town and of the Schuylkill Canal. Mark Bird, his son, was probably born here. At that time, it is said, the

1 History of Berks County. 


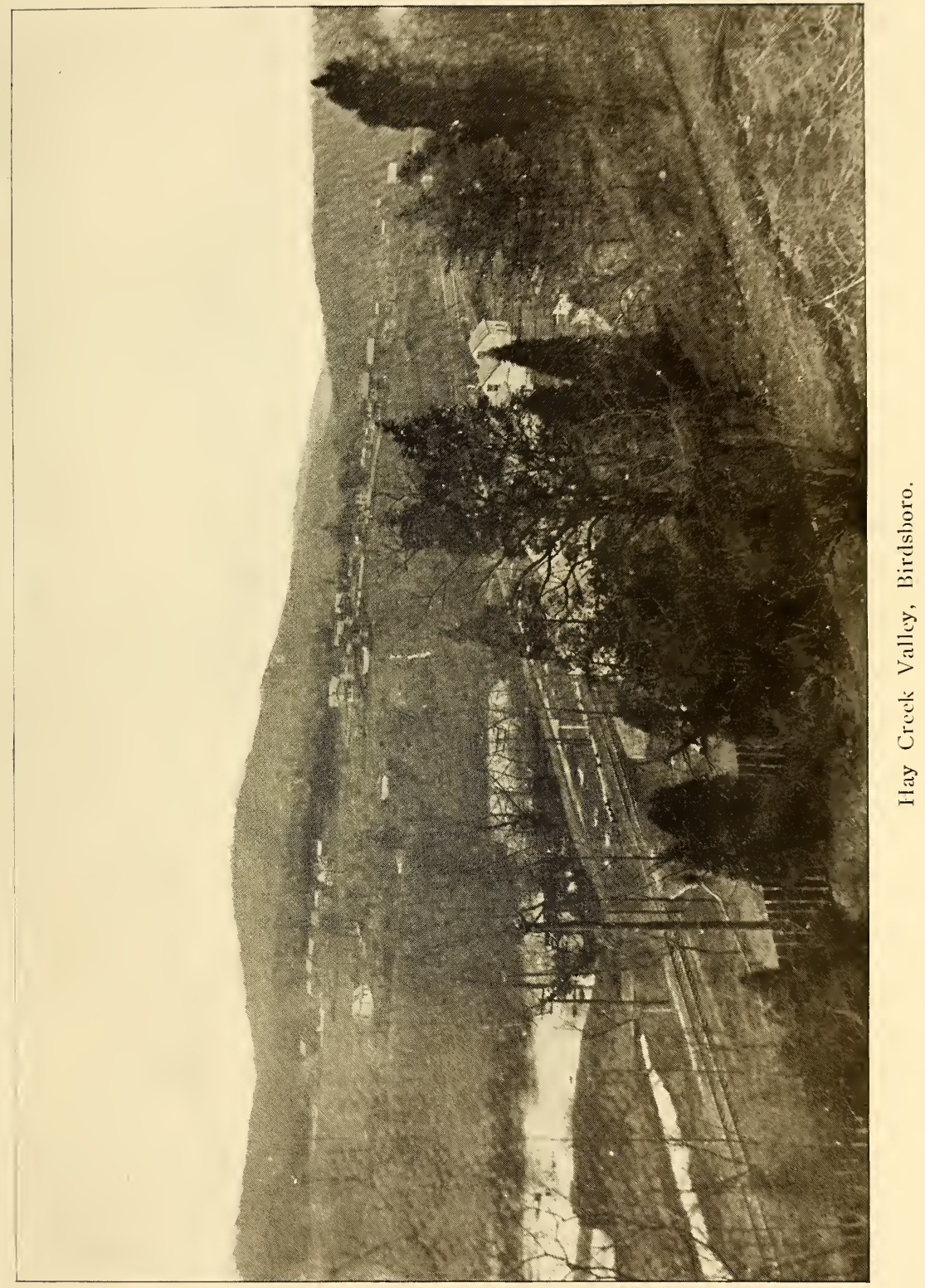



house was surrounded by a deer park, sloping to the river, which must have been a means of communication with other places, as well as a natural beauty of the property. Watson, in his "Annals of Philadelphia," mentions the interesting circumstance that upon the occasion of the wedding of Magdalena Hulings, a native of Morlatton, and daughter of one of the early settlers, Marcus Hulings, - to Matthias Holstein, of the Swedes Ford, the bride with her entire retinue-made the journey thither in the canoes. So cannot we picture Marcus Hulings' other daughter on her way to the Bird Iron Works?

Mark Bird, according to Montgomery," "after his father's death, took charge of the estate, and by partition proceedings in the Orphans Court came to own the properties. ... By the time the Revolution broke out, he had enlarged his possessions very much and had come to be one of the richest and most prominent and enterprising men in this section of the state. . . . In 1775 and ' 76 Mark Bird was the Lieutenant Colonel of the 2nd Battalion of the County Militia, which was formed out of companies in the vicinity of Birdsboro; and in August, I776, as a colonel he fitted out three hundred men of his battalion with uniforms, tents, and provisions, at his own expense."

The disturbance of business by the Revolution, and the monetary troubles after its close, brought about his failure.

"At the Sheriff's Sale in 1788 the forge property was purchased by Cadwallader Morris, James Wilson and others of Philadelphia; and in 1796 John Louis Barde became the owner. Matthew Brooke married a daughter of Barde and subsequently purchased the property. It has since remained in the Brooke family." 2 We find in Mr. Swank's "Iron Making in Pennsylvania," page 30:

1 Berks County in the Revolution.

2 Montgomery, History of Berks County. 
"Mark Bird built a rolling and slitting mill and a nail factory at Birdsboro about the time of the Revolution. He also built Spring Forge in Oley Township and Gibraltar forges in Robeson Township. At Trenton, New Jersey, he manufactured wire. The town of Birdsboro, in Berks County now the seat of the extensive iron works of Messrs E. \& G. Brooke was named after William Bird."

Mark Bird's wife was Mary Ross, daughter of Rev. George Ross. His daughter married James Wilson, the Signer.

About 1788 Mark Bird moved to North Carolina, where he died. We find his name, together with that of his brother-in-law, Edward Biddle, and of his step-father, Colonel John Patton, very prominent in the early Revolutionary era.

Cornelia L. E. Brooke. 


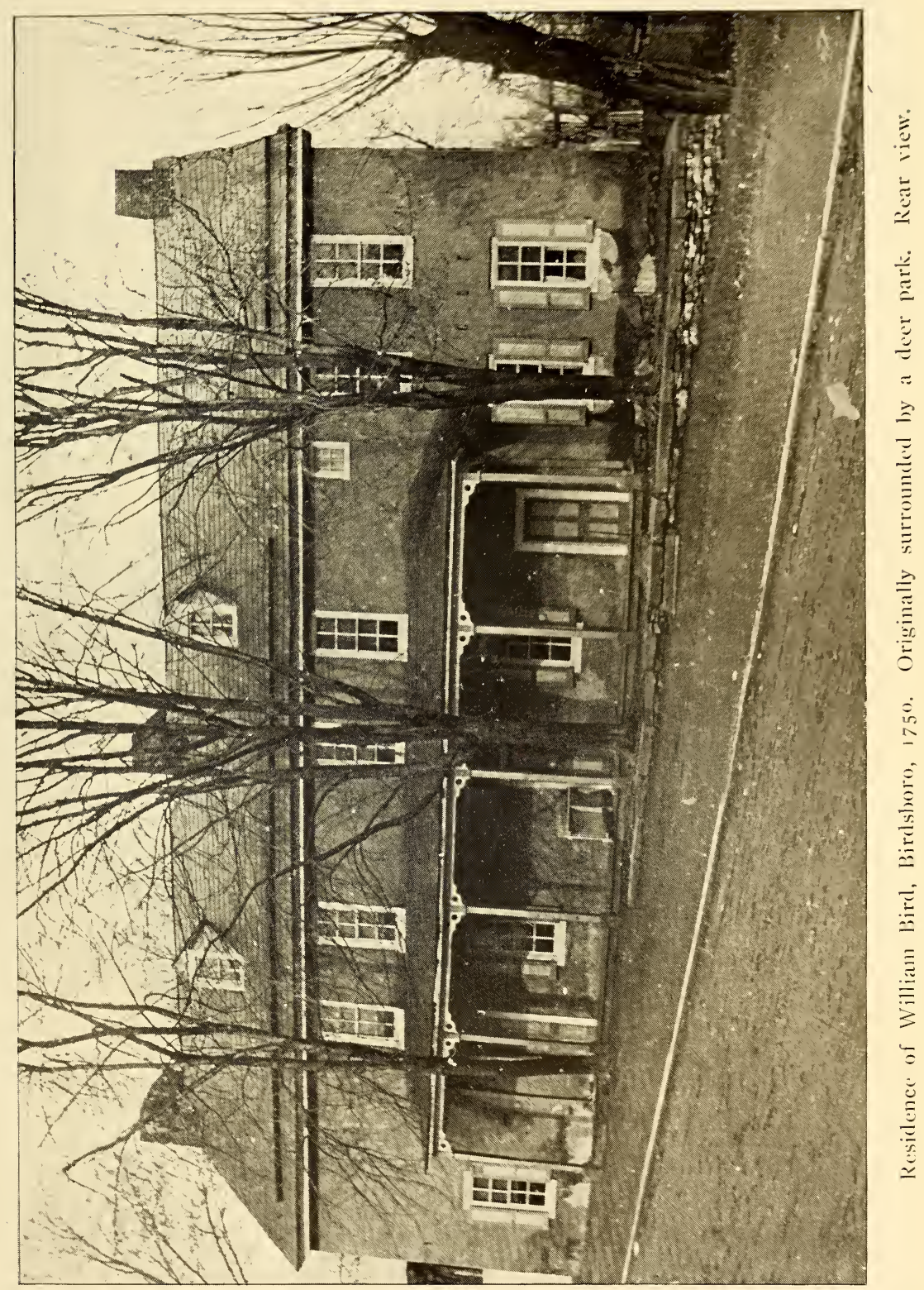





\section{NEW PINE FORGES.}

\section{Berks County.}

Information as to these forges in Union township has been gathered exclusively from the "Cole Book" and ledgers in the manuscript collections of the Pennsylvania Historical Society. Evidently William Bird was the owner, and the records mention a Lower, Middle, and Upper forge. One of the earliest books is entitled "New Pine Forge Cole Book," I744-I76o. A coal book gave details of the making and hauling of charcoal and its later disposal. A heading, for a carefully spaced page runs: "Account of Coles made and sent to Hopewell Forge by John Surrie for the year I744." "Pigg Iron from Warwick Furnace upon $\operatorname{acco}^{\text {tt }}$ of Mr. Robert Grace. For the Euse of $\mathrm{Mr}$. $\mathrm{W}^{\mathrm{m}}$ Bird at Hopewell Forge for the year I744." "Account of Pigg Iron sent to Hopewell Forge anno I745, since Silvanus Maybury came to work."

Another: "Oct. 1756. New Pine Forges to Rokxburry Furnace, D."

An interesting entry is: "Compiled by John Fegan, for the Middle Forge; an account of the building of the Middle Forge. The first stone laid on Foundation July the $29^{\text {th }}, 1757$. The raffters raised August $19^{\text {th }}$, The Fore Bay made August $26^{\text {th }}$. The Covering finished September $5^{\text {th }}$. The geers raised October the fifteenth. The Anvil Block fixed October $25^{\text {th }}$. The shafts fixed the $29^{\text {th }} \mathrm{d}^{\circ}$. The Chiefry and hammer wheel finished November the I $9^{\text {th. }}$."

From New Pine Wast Book:- "Dec. 1757. John Huling $\mathrm{D}^{\mathrm{r}}$ to 23 Shovel plates.

"Francis Morris D". to I Bake Plate 
"Yorke \& Potts Dr. to I ton Barr Iron by Andrew Huling."

From Cole Book: "The new wagon measured at the Lower Forge, and it measured 8 Seams. Each seam Eleven Bushel."

"Memorandum, that I have this $14^{\text {th }}$ day of November, I757 agreed with William Bird Esq. to begin . . . to serve him as carter for I year, at the rate of L I9 per year, meat, drink, washing \& lodging.

\section{CONRAD + Wishon \\ his mark" \\ Witness present \\ John Fegan}

On fly leaf: "Day Book, Kept at New Pine, Union Township, County of Berks, for William Bird Esq. I 759."

"John Lincoln Cr. by self and boy taking 3 tunn barr iron in a canoe to Spring Mill, Feb. I760."

"Patton and Bird" the owners of "Rocksburry" Furnace a frequent term from $\mathrm{I} 760$ : and in 1763 , "Patton and Bird $D^{\text {rs }}$ for the stock received from $W^{m}$ Bird."

"I760. Jacob Lenan got stoves, midlen and small."

"Paid Mr. Mark Bird's expences to Phil" I-I I-6Sept. I76o."

" 22 July I76I, Nicholas Scull for hauling I Hhd Rum I-O-O-

"Roxberry" Furnace frequently bought bar iron, items at store, etc. in $1760-6 I-62$.

"Wood taken up by Stephen Doughten on Abram Lincoln's Plantation for the year I $760 . "$

"Reading, March I7, I764. Mark Bird ... from the time his partnership broke off, at I4 Feb. att the Forge"-etc.

In the New Pine Forge Ledger, I775-I777, the follow- 
ing names, (with others) are mentioned under Forge Charge. John Patton, Paul Zantzinger, Curttis Grubb, George Ege, Adam Kalbach, Joseph Krebs, Hanes Zerby, Charles Stedman, James Old, George Veneada, Thomas Mayburry. The entries in this book end April, 1778. The rest of the volume is filled with Charming Forge accounts, beginning January, I 823 .

Additional entries:

"Lawrence Doyle, Dr. to rum when you was sick. . 4 to syder when you was ditto. 3"

"Agreement made 29th of February I 762 with James Foley and Patton and Bird to do team work for one year."

"Agreement on the part of Gabriel Hughes of Exeter township Berks Co. July Ist I 762 to deliver wood to John Patton."

"Oct. 6th I762 Agreement between John Boyer and Patton and Bird to drive team one whole year from the date hereof, for the due performance of which said Patton promises to pay him the sum of twenty six pounds and two pair of shoes."

"Agreement with John Shaw July 23rd I76r to stock the upper Forge, and at any time to assist in stocking at any of the other two forges when he has not stocking to do at the said upper forge. The said Shaw is to be paid for the faithfull performance of the above agreement eighteen pounds and a pair of shoes, and if he does not get drunk above once in three months, a pair of stockings and his diet."

"By Negro Dick's board 2 I Nov. I7 to I4 Feb. 1763 —£IO-O-O.

New Pine Forges Dr. to Rocksburry Furnace April 29, 1760. Mark Bird, To Cash paid at Roxburry Furnace 
£20. Bird \& Patton $D^{r}$. To hauling 3 tun of Stoves from the furnace $60-0$.

An interesting question arises from the finding of these old ledgers and the quaint Cole Book. Were these the original iron works of William Bird (Hay Creek or Birdsboro forges) under a name unknown until now? The writer of the articles on Hay Creek Forges and Hopewell Furnace is quite confident they are the same.

Augusta $M$. Longacre.

HOPEWELL FORGE.

Lancaster County, later Lebanon.

Peter Grubb erected this forge on Hammer Creek, six miles southeast of Cornwall, before building the large blast furnace at the latter place. He had taken up the land in 1737. Hammer Creek was the largest stream in the neighborhood and furnished excellent water power. Two Hopewell forges were built here, but at what time is not known. Mr. Grubb may have run one as a bloomary or Catalan forge, bringing the ore from Cornwall for that purpose. ${ }^{1}$ Here Peter Grubb had his home. He was born at Marcus Hook, I707-8, and died in I754. Coming into possession of Curtiss and Peter Grubb at their father's death, these forges became finally the property of Robert Coleman when he bought Cornwall. In early life he had been here as a clerk with the Grubb brothers, but soon, by rapid steps, became himself an iron master.

1 H. C. Grittinger, Cornwall Furnace and Ore Banks, p. I4. 


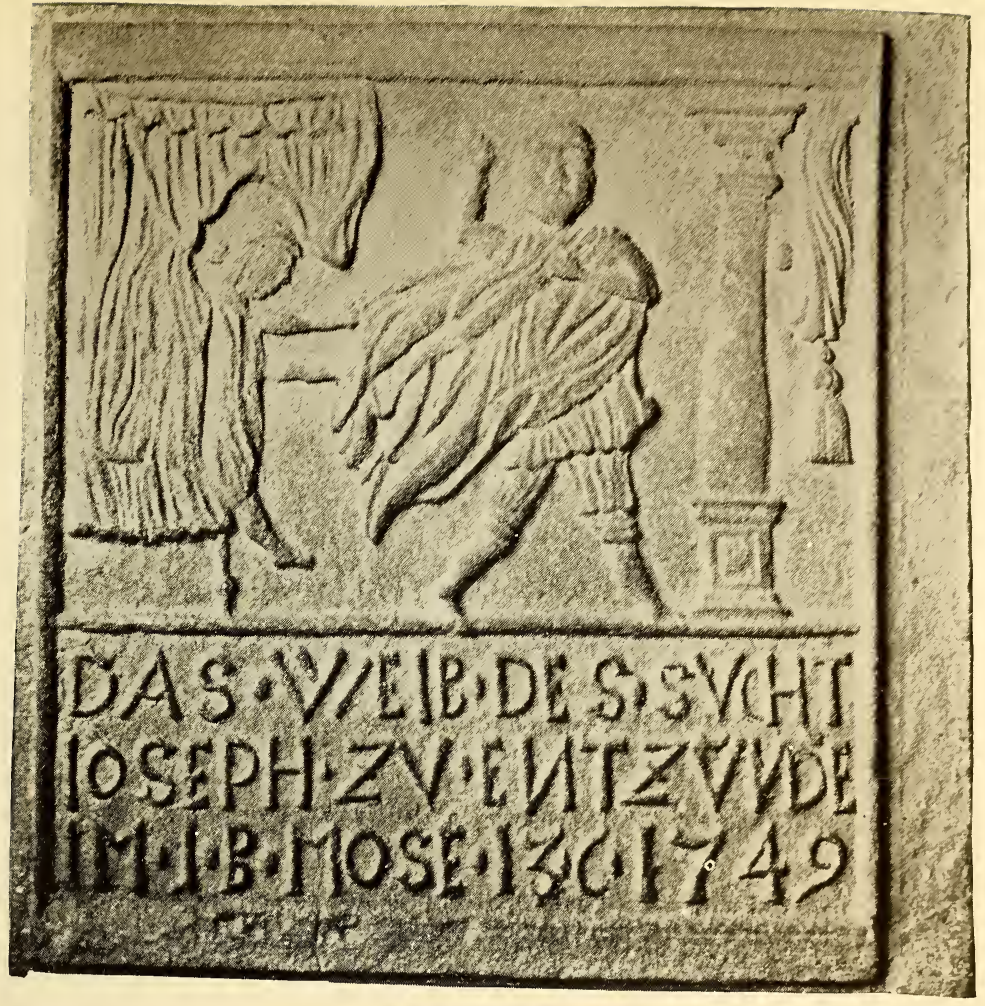

Stoveplate, Joseph and Potiphar's wife, 1749.

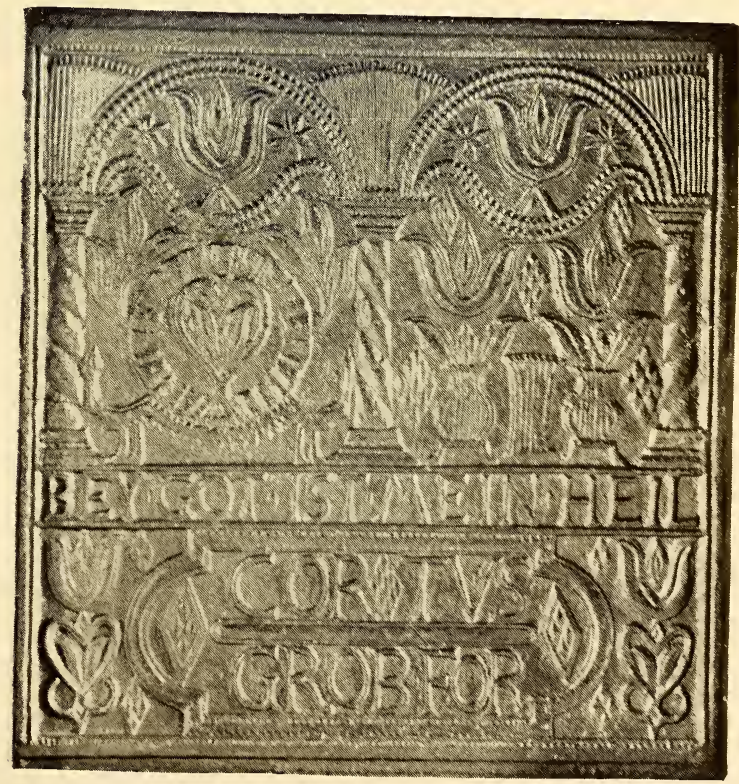

Curtiss Grubb's Furnace. "In God is my Salvation." 



\section{CORNWALL FURNACE.}

\section{Lancaster County, Later Lebanon.}

Foremost among the natural glories of Pennsylvania are the great ore banks of Cornwall. Before the development and opening up of our western country, no traveler from foreign lands was content until he had seen these mountains of magnetic iron ore; three solid hills, from which rich ore was dug, at very low cost. They were called the Large Iron Hill, Middle Hill and Grassy Hill. Roughly speaking, the total area of these ore mines is something approaching one hundred and ten acres, and now, after having been worked for one hundred and seventy years, they seem inexhaustible, and require no mining, simply to be quarried.

Acrelius, the Swedish historian, writing in 1756 , of "Cornwall, or Grubb's Iron Works in Lancaster County," said: "The mine is rich and abundant, forty feet deep, commencing two feet under the earth's surface. . . .Peter Grubb was its discoverer." And this statement of the old Swede seems to be the final verdict to-day, as to the first recognition of the possibilities of these wonderful hills. Mr. H. C. Grittinger, in his able monograph on "Cornwall Furnace," says: "It is to be presumed ... that it was Peter Grubb who first developed and used the ore, as the two individuals who preceded him in the ownership of the land, and who both sold their holdings for nominal amounts, evidently knew little or nothing of the ore deposits; and they were both iron masters, and members of the company that had built and were operating Durham Furnace in Bucks County in I727."

On the 8th day of May, I732, John, Thomas, and 
Richard Penn, for the sum of $£ 500$, money of Pennsylvania (a pound Pennsylvania currency being worth $\$ 2.66$ $2 / 3$ of our present money) granted a warrant for five thousand acres of land in the Province of Pennsylvania to Joseph Turner of the city of Philadelphia, who afterwards assigned it to William Allen. By agreement, April 5, I734, William Allen sold three hundred of the five thousand acres of the land called for in the warrant, to Peter Grubb for the sum of $£_{135}$, who procured a patent deed for.it from the proprietaries on the 3oth day of November, I737. This grant, however, did not entirely embrace the ore hills, so the evidently clear-sighted Peter Grubb made two other purchases of land from the Proprietaries, which made him sole owner. The two brothers, Peter and Samuel, were the sons of John Grubb, who came from Cornwall, England, in I692, landing near Wilmington, Lower Counties, on a spot afterwards called Grubb's Landing. He was a member of the Provincial Legislature of Pennsylvania from I694 to 1698 . He is buried in the Swedes' graveyard, Wilmington. Mr. James M. Swank, the great authority on iron, thinks that Peter Grubb's first essay in iron making was with a bloomary forge in 1735 , near the site of the later Cornwall Furnace. The existence of this early bloomary is attested by the traditions of Cornwall. About a mile from the great furnace, small pieces of slag and several pieces of white iron were found by Mr. Grittinger, one of which he presented to the Lebanon county Historical Society as a sample of the first iron made in Lebanon county. From this small beginning - and it was so small that the spring run on which it was situated was too insignificant to furnish water power to run the bellows, so that it must have been worked by hand-from this has come the greatest of Pennsylvania iron industries. 



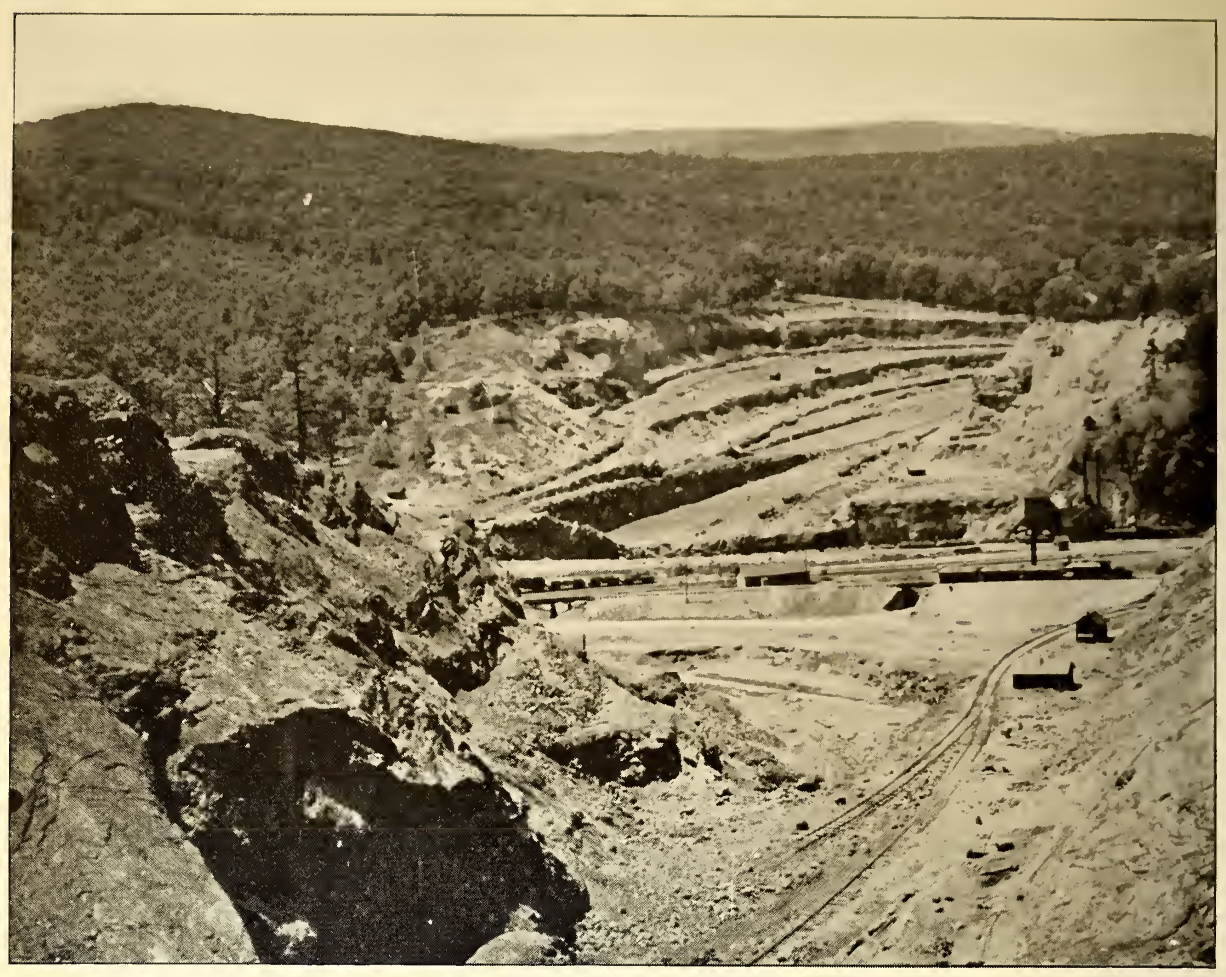

Cornwall Ore Banks. View from Big Hill.

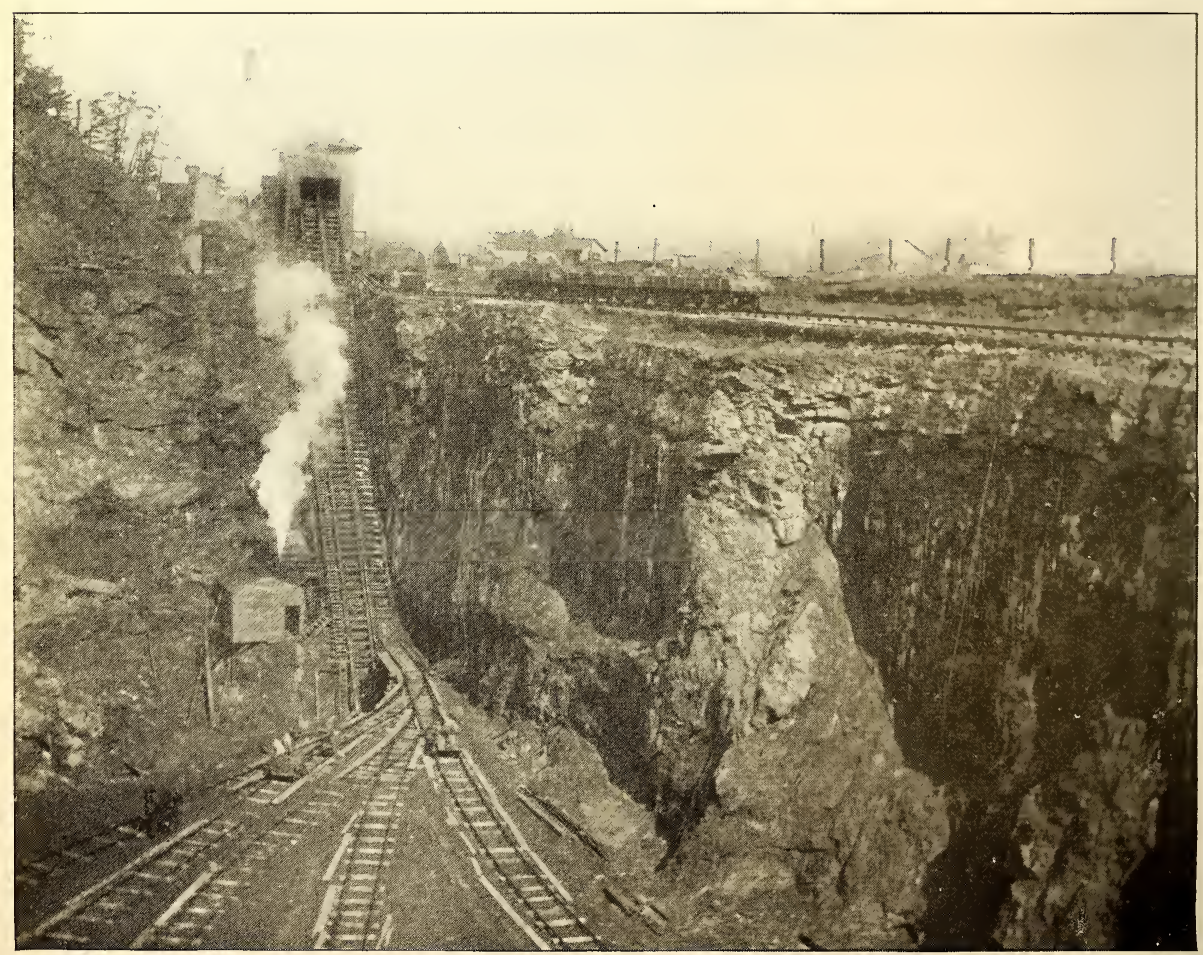

Cornwall Ore Banks, Robesonia Cut and Hoist. 
An indenture in possession of the Grubb family, reads as follows:

"On the 22nd day of September in the thirteenth year of the reign of King George the Second over Great Britain, France \&c, Anno Domini 1739, between Peter Grubb of the township of Warwick in the County of Lancaster, of the Province of Pennsylvania, Iron Master, with Samuel Grubb of East Bradford, in the County of Chester, a Charcoal Furnace to be built, \& to be called Cornwall-"

Planned thus in I739, and first in blast in I742, Cornwall furnace, about the size of Warwick furnace, began its long existence, being named for Peter Grubb's ancestral county in England. Having been blown by its owner for three years, it was, in I745, along with the Hopewell forge which belonged to Mr. Grubb, leased to twelve persons, ${ }^{1}$ who managed it for a few years only, under the name of the Cornwall Company. For the remainder of the term it was conducted by Jacob Giles, a Quaker of Baltimore. ${ }^{2}$

Peter Grubb remained sole owner of the ore banks until his death, in 1754 , when they became the property of his two sons, Curtis and Peter, Curtis as elder son, under the intestate law of that day, receiving two thirds and Peter one third. These men have a patriotic record, having both been colonels in the Revolution. To judge from an account of the gayeties of Hessian prisoners, at Hebron, Lebanon county, in August, I777, the officer in charge, Col. Curtis Grubb, must have had his own trials. Much to the distress of church members, the prisoners were quartered in churches. The Moravian church seems to have suffered most, as the Hessians destroyed fences and other property, and taking the Church violins, solaced themselves with playing and dancing. ${ }^{3}$

1 Acrelius, 1756, speaks of its being rented then to Gurrit \& Co.

2 Bishop, American Manufactures.

${ }^{3}$ Publications of the Lebanon County Historical Society. 
Under the ownership of these patriotic colonels, Cornwall furnace, during the war, cast cannon, shot, shell, and stoves for the Continental Army. A letter relative to cannon cast at Cornwall is interesting.

\section{"To Col. Peter Grubb,}

"Philadelphia i 8 September 1776

"Sir,-By Capt. Joy I understand you have at last made some I 2-Pounders, but I fear they are heavier than they ought to be. Those made by Col. Bird weigh but $27 \mathrm{c}$ and some under.

"You have drawn on the Committee for $£_{1500}$, it is not sent because the matter is not understood. We can't suppose you want such a sum to carry on the Works, \& you certainly don't desire the Cannon to be paid for before they are delivered.

"The sum you draw for is the value of the Guns already made, \& as the contract was made with your Brother, Col. Curtis Grubb (Tho' you may be equally interested with him), yet I should like to hear from him before so large a sum was paid; however, I have sent you by Capt. Dan'l Joy one thousand dollars. I mentioned to Congress your inclination to have some of the prisoners from Lancaster to work for you, but it was supposed the Committee of Lancaster would object to it. I hope you will make all expedition in making the Cannon \& getting them down, for they are much wanted.

"The Cannon must be proved with two shott, or they will never be put on board the Ships. I am your hum'l Serv't."

R. T. PAINE."1

In 1783 Curtis granted and conveyed inter alia to Peter Grubb, his eldest son, and to his heirs and assigns forever, the full equal undivided one-sixth part of all his estate, including the Cornwall ore banks or mine hills. In 1785 , Peter Grubb, 3rd, son of Curtis Grubb, entered into articles of agreement with Robert Coleman to sell and convey to him, all his right, title and interest of, in and to the

1 Egle, History of Lebanon County. 



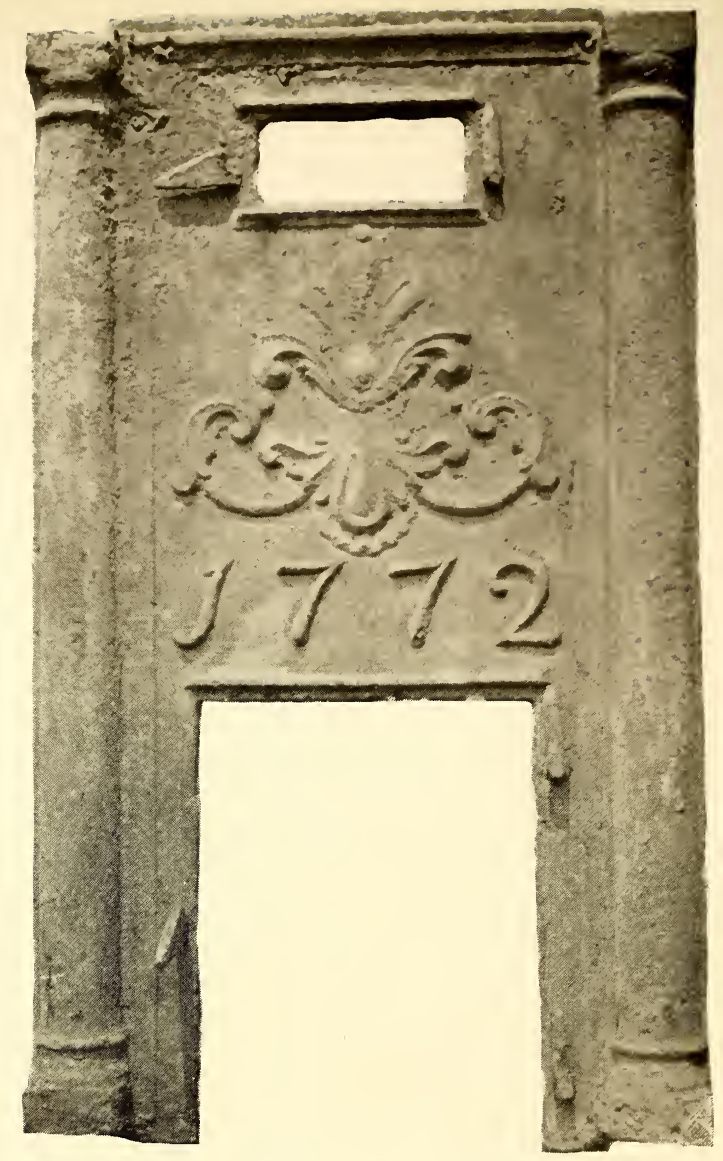

Front plate of Stove. Cornwall Furnace, 1772.

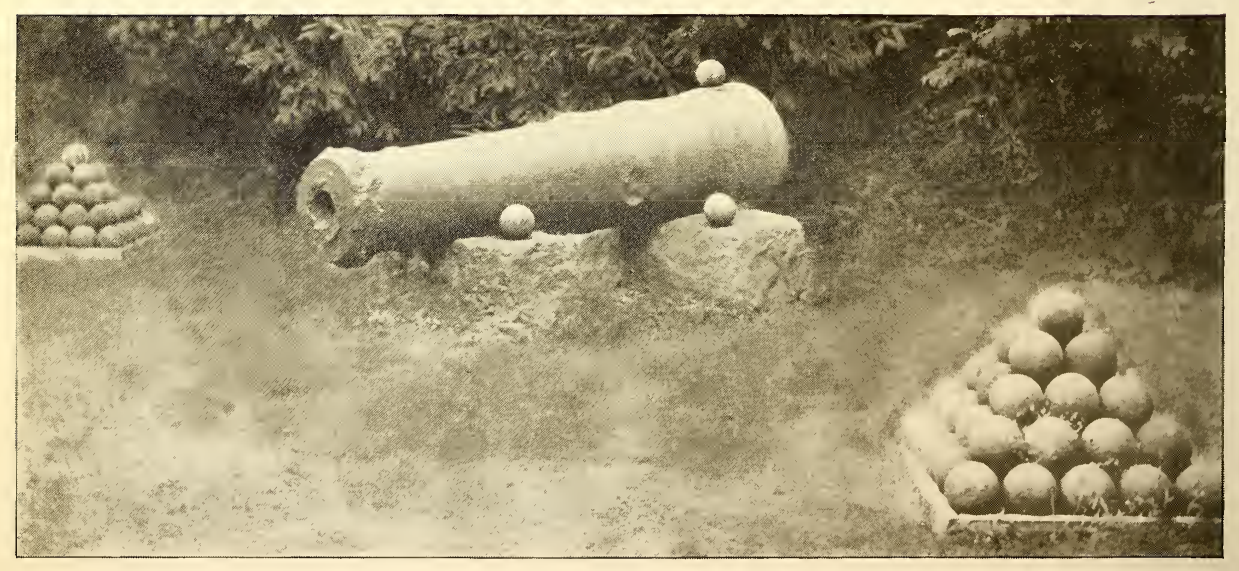

Cornwall Furnace, i776. 
said undivided one-sixth part of the estate above referred to. In I798 Robert Coleman had purchased from the various Grubb heirs five-sixths of the ore banks-the remaining one-sixth being held by Henry Bates Grubb.

It is now more than a century and a quarter since Robert Coleman became the chief owner of this great mine so identified with his name and that of his heirs. Although his children and descendants have lived at Cornwall, he did not. In the history of his life, in his own handwriting (the property later of his grandson, George Dawson Coleman) Robert Coleman states that he was born near Castlefinn in County Donegal, Ireland, on the fourth day of November, I748, and in 1764 , when sixteen years of age, came to America to seek his fortune. His capital then consisted of a sound body and a good education, the latter not a common thing in those days. He brought a letter of introduction to Blair McClenachan and the Messrs. Biddle, and by them was recommended to Mr. Read, Prothonotary, Reading, Pennsylvania, in whose employ as clerk he remained nearly two years. The young man, however, had higher ambitions than being a clerk in an office, and like many of his day and since, started out into the wild country to seek his fortune. He quickly found himself in the iron ore district and obtained work from the Grubbs at Hopewell Forges. Six months after he got a better position at Quittapahilla Forge (afterward known as New Market Forge), about eight miles west of Lebanon, then operated under a lease by James Old, who was also the owner of Speedwell Forge, located on Hammer Creek, a short distance below the Hopewell Forges. Mr. Old found the young man so intelligent, industrious and generally satisfactory, that when he moved to Reading Furnace on French Creek he gave Coleman a higher position and took him with him. While at this furnace Robert Coleman married Anne Old, a daughter of his employer, 
October 2, I773. Soon after, finding that he had accumulated enough capital to set out for himself, he rented Salford Forge, near Norristown, for a term of three years.

From Salford Forge he removed in 1776 to Elizabeth Furnace, where he lived until I809. He never made his home at Cornwall, although his interests there were great, extending even to the beautiful gardens which were planned under his direction, by a Frenchman, who also laid out the gardens at his home, the Mansion, at Elizabeth, which Mr. Coleman practically built after purchasing the property. ${ }^{1}$

A man of strong character, and great capacity, Robert Coleman was the most noted iron master in Pennsylvania. For an estimate of his business ability by a contemporary, we cannot do better than quote from Hazard's Register of I 83 I : "R. Coleman Esq., became the most successful proprietor of iron works: to untiring industry and judicious management he added the utmost probity and regularity in his dealings, and to him Lancaster county is especially indebted for the celebrity it has acquired from the number and magnitude of its iron works and the excellence of its manufacture." While, during the struggle of the Colonies with the Mother country the Grubb brothers were eminently patriotic, Robert Coleman, then at Elizabeth Furnace, was in no whit behind them.

He was an officer in the Pennsylvania militia during the Revolutionary War, a member of the State Convention which framed the Constitution of 1790 , and a member of the Legislature. He raised and commanded a troop of cavalry during the Whiskey Insurrection, was twice a Presidential elector, and an Associate Judge in Lancaster for nearly twenty years. ${ }^{2}$

${ }^{1}$ From notes furnished by Mrs. Horace Brock, great-granddaughter of Robert Coleman. See Salford Forge.

2 See Elizabeth Furnace and Salford Forge. 
He retired from business and moved, in 1809 , to Lancaster, where he died on the I4th August, I 825.

His son, James Coleman, inherited Elizabeth, while the younger sons, T. Bird Coleman and William, were settled at Cornwall. Later Robert Coleman's grandson, Robert Coleman, with his brother, G. Dawson Coleman, removed to Lebanon and built furnaces there on the Union Canal, which was then the great means of transportation. Coal could be received and iron shipped from there better than from Cornwall or Elizabeth, whence they had to be hauled by teams; and by that time charcoal furnaces were going out.

"Both Cornwall Furnace and the early bloomary were near the old road that had been the original thoroughfare through the southern part of what is now known as Lebanon county between Harris's Ferry and Philadelphia. On some of the old maps this is called 'The Paxton Road': tradition says the name was given because 'The Paxton Boys' had marched over it on their way to Philadelphia at the time of their insurrection in February I $764 .{ }^{\prime \prime}$

Of the output of these great mines we are told that "prior to the development of the Lake Superior iron ore region the Cornwall mines were annually the most productive group of all the iron ore mines in this country and this distinction they held for several years after Lake Superior ores came into general use."

"Down to 1908 these mines had produced more iron ore than any other single iron ore property in the United States, including the most productive of the Lake Superior mines." 2

\section{Augusta M. Longacre.}

1 Grittinger, Cornwall Furnace and Ore Banks, p. r4.

${ }^{2}$ Swank, Progressive Pennsylvania, p. 219. 


\section{MOUNT JOY, OR VALLEY FORGE.}

\section{Chester County.}

Every good American associates with Valley Forge events which deal with military rather than industrial history. Yet an early forge was located in Chester County on the western side of Valley Creek, a little more than half a mile from its mouth. The "mountain" opposite, from which the forge first took its name, is said to have been named "Mount Joy" by William Penn, who also owned a manor so named on the Schuylkill. The tradition is that a nearby hill was called Mount Misery by the Founder, as the ascent was most difficult.

Evan-Ap-Evan, a Welshman, in the year 1686, emigrated from his native land to take up and occupy a tract of land comprising some two thousand acres, including what is now known as Valley Forge. Some of the descendants are still in possession of a portion of the original grant of 1684 , to Evan-Ap-Evan by the proprietor. ${ }^{1}$ Early data regarding the founders are very difficult to obtain. It is certain that there was some manufacture of iron products at this spot in the early years of the eighteenth century. Mr. J. M. Swank ${ }^{2}$ mentions an early and misty tradition that the forge was built by an Englishman named Walker, who came over with William Penn. Possibly this was a relative of the later owner, for there are in the possession of ex-Governor Pennypacker, who owns a large and priceless collection of original ledgers and accounts, connected with some of the earliest Pennsylvania iron-

${ }^{1}$ Henry Woodman, in Bucks County Intelligencer and Moorestown Herald, 1897. Art., "Valley Forge."

- 2 Ironmaking in Pennsylvania, p. 28. 
works, the ledgers of this forge, showing the ownership after 1742 .

In that year a forge was erected under the firm name of Walker and Company, by Daniel Walker, Lewis Evans and Joseph Williams. They sold out on March I 2, I757, to John Potts, of Potts Grove. Indications are that there was an earlier forge, for Acrelius ${ }^{1}$ mentions two iron works in I 759 in the "Great Valley," and Futhey and Cope, ${ }^{2}$ referring to these, say that this may have been in the neighborhood of Valley Forge. They add, "September 26, I75 I, a Stephen Evans and Joseph Williams advertise for sale a two thirds interest in three hundred and seventy five acres near the mouth of Valley Creek, with forge and saw mill thereon."

The earliest entry in the account book referred to is dated March I8, I757. The firm owned two hundred acres of land in Chester County, and one hundred and seventy-five in Philadelphia County. A forge and saw mill stood on the south side of the creek, on the latter tract. Daniel Walker had held a mortgage on one third of the tract, which he had foreclosed. Ex-Governor Pennypacker owns an interesting "peel," made by Walker and Company, at the Valley Forge of Mount Joy. It is a spade-shaped implement, with a very long handle, used by housewives to take from the oven the bread and pies which could not otherwise be reached in its depths. Under the Potts ownership, James Hockley was put in charge. His name occurs in a cash account so early as 1738 , and he had probably occupied that position under former owners. "James Hockley, $\mathrm{Cr}$. by cash paid toward getting Waggons to go to Ohio, two and six. June 7, I738." "Cash paid to yr. Wife five shillings."

1 History of New Sweden.

${ }^{2}$ History of Chester County, Pa., p. 316. 
John Potts immediately began improvements on the property. He erected a grist mill, a blacksmith shop, a cooper shop, and started a store. Samuel Watkins, a blacksmith, was paid thirty pounds a year. People as far away as Coatesville bought their shoes at the forge store, while four tons of iron at a time were piled up, and hauled by wagon to Philadelphia. The work was done by negro slaves and by two white men classed as "servants" on the books, and who were really "redemptioners," named Thomas Connor and Henry Seligman, who had been bought for thirty pounds each. Teamsters were paid twenty pounds a year. Candlesticks, sleeve buttons, "mohaire," camblet, and "callicoe," "green Knap," molasses, jacket buttons, men's shoes and snuff boxes, molasses and "garters for your wife" are all jumbled up promiscuously and delightfully in the accounts. Philip Piner bought a "bake-plate" weighing twenty-seven pounds at three pence per pound, for which he paid six shillings and nine pence. The hire of a pair of negroes for "Negro Strephon" (probably to assist him) cost one shilling and six pence.

On the tenth of August, I758, "a heifer hyde, wt. $37 \mathrm{I}$ lbs." was sent to Isaac Wayne, and October 24 of the same year, "hydes" were sent to Isaac Wayne's son, afterward famous as "Mad Anthony" Wayne. The "First Artikel" at Mount Joy Forge is noted as having cost "two hundred shillings," but very unfortunately, we are not told what the "artikel" was.

From the year I77I Colonel William Dewees, son of William Dewees, Sheriff of Philadelphia, was associated with the Potts family, and appears to have been a resident manager at Mount Joy. In I 773 he bought an interest in the business, but the manufacture of iron ceased to flourish on Valley Creek after the outbreak of the Revolution. The iron used at Mount Joy was brought from the furnace 


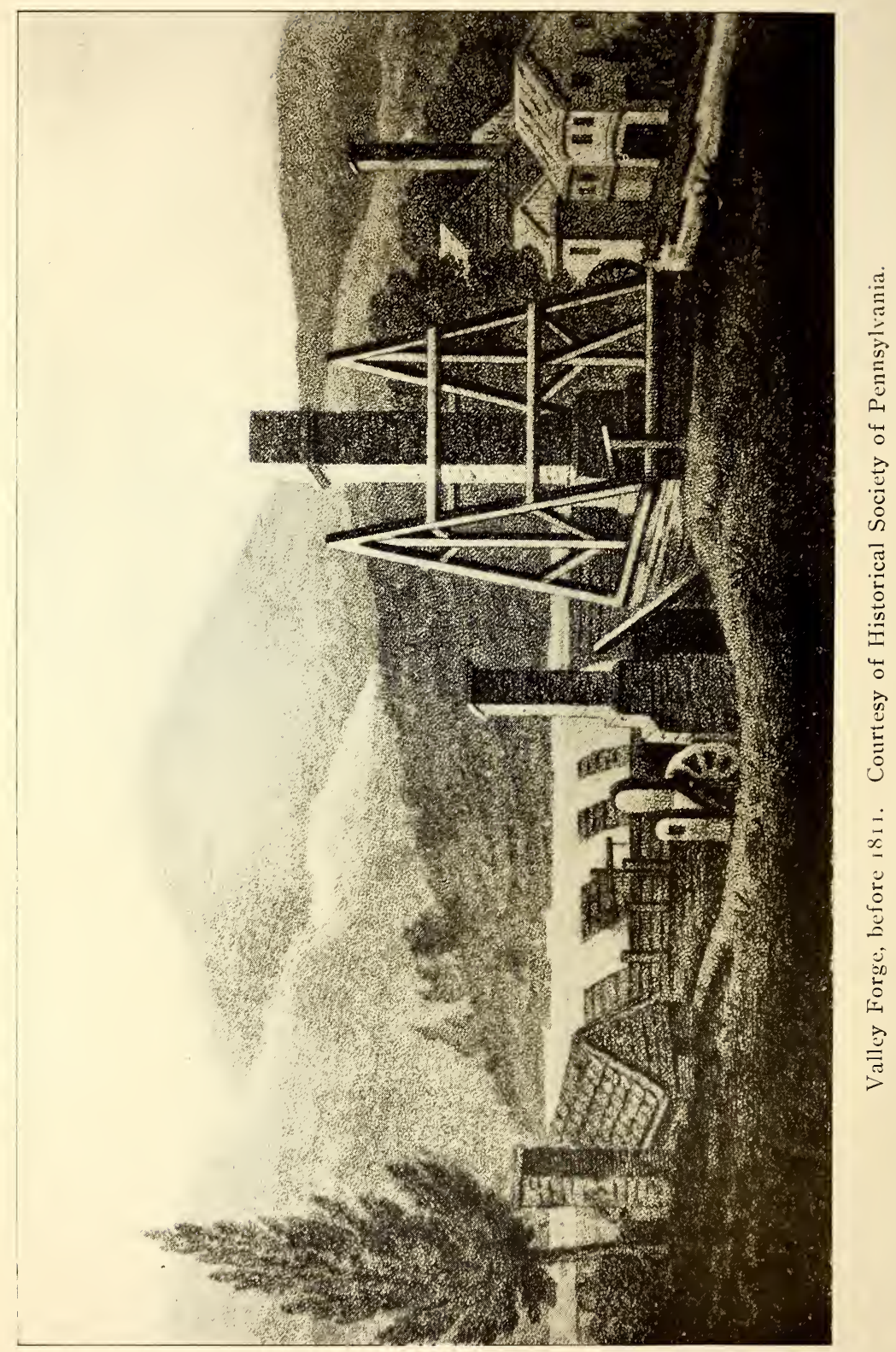


at Warwick by heavy teams over a road which Samuel Nutt, Jr., of the latter place, had been at great pains to open and improve. Another road in the county which was located and built through his father's efforts in 1735 , still bears his name.

For several years during the Revolution the forge at Mount Joy, so sadly misnamed, became the scene of far other incidents. Its history takes on the red hue of "battle, murder and sudden death," rather than the fiery glow of a great iron industry. The battle of the Brandywine was fought September II, I777. The British army under General Howe lay for a few days in Tredyffrin township, and while there, a detachment was sent to the Valley Creek, which destroyed Mount Joy Forge, together with property belonging to William Dewees to the amount of $£_{4}$ I 7 I or \$I I,000 Pennsylvania currency, including "two large stone dwelling houses, two coal houses, four hundred loads of coal and twenty two hundred bushels of wheat and rye in the sheaf." The detachment that committed this depredation was in charge of Colonel Gray, the superior officer of Major André, at Paoli. One historian of this disaster tells us that his mother, as a young girl, accompanied her aunt in a frightened search for her cousin John, and upon their return, beheld the forge a smoking ruin. The conflagration was witnessed from the top of Mount Joy, the hill from which the forge took its name, by Colonel Caleb North, of the Continental forces. One or two venerable trees were spared, which were recently living.

The massacre at Paoli followed in a few days (September 19) and this enabled Howe to move unmolested. On the twenty-third, after a futile attempt to cross the Schuylkill at Swede's Ford, he made'a successful effort by dividing his forces, one half crossing at what is now Phœnixville, and the other at Fatlands Ford, close under Mount Joy, 
after which the united army successfully moved toward Philadelphia, which it triumphantly entered September 26.

The greater interest for Valley Forge, however, comes to us for far other reasons than that an invading army crossed the Schuylkill at this point. General Washington, encamping for a time near the Perkiomen Creek, at Pennypacker's Mills, disputed the possession of Philadelphia with the British at Germantown in October, and eventually retired for the winter to those quarters which have since made Valley Forge a spot so famous and so sad. The secluded situation was probably the chief reason for its selection. General Washington made his headquarters in the house of Isaac Potts, and the property remained in the possession of that family for many years after.

The firm of Potts and Rutter, in 1757 , cast at Warwick a bell, marked P. R. I 757 which was used to call the men to work for more than a century. In May, I874, it was sent to Colonel J. M. Fager by Thomas W. Potts, Jr., and interest is doubly given to this old bell by the fact, that while Washington was at Valley Forge, it was rung to assemble the citizens to bury the cannon, that they might not fall into the hands of the enemy. This bell was presented by Colonel Fager to the city of Philadelphia, and was an object of great interest at the recent reopening of Congress Hall.

Directly opposite Valley Forge stands a fine estate, called Fatlands, or Vaux Hill, from the name of the owner, James Vaux, who came to America from England just before the outbreak of the Revolution, and located at this point. The ford leading to Valley Forge is that where General Sullivan was deputed by Washington to construct a pontoon bridge. Over this, at the evacuation of Valley Forge, the army crossed, passing up the lane near the mansion. The dam constructed for the later forge obliterated 


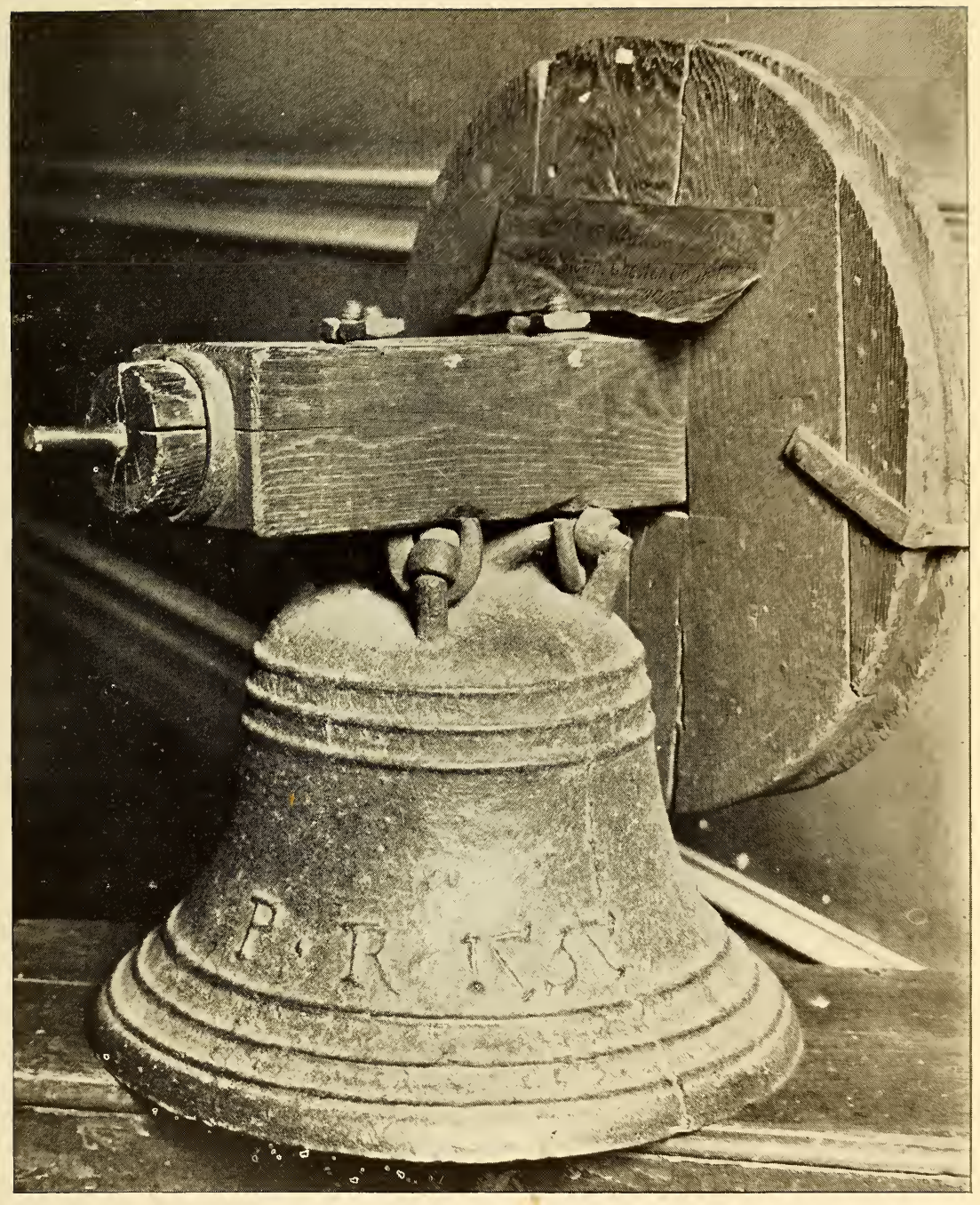

Bell rung at Valley Forge as signal to bury the cannon on alarm of approach of enemy. Cast at Warwick Furnace, 1757. Now in Congress Hall, the gift of Col. Fager. 

the ford, and the point where stood the bridge is marked by a small monument.

James Vaux was a Quaker, and with the non-partisan sentiments of his sect-although he was all along a patriot, and afterward joined the militia-his house was open to all comers. After the retreat from Brandywine, while the Continentals were lying at Pottsgrove, the British lay at Valley Forge. Washington, with the intention of inspecting the enemy, arrived at the house of James Vaux on the afternoon of September $2 \mathrm{I}$ and obtained an excellent view of the opposing forces. He supped and passed the night with his host, and left after breakfast next morning.

That same afternoon, Sir William Howe arrived, remarking to his host that from what he had seen through his glass, he thought some distinguished rebel officer must have been there the night before. On being told that it was Washington himself, he was greatly vexed, declaring that had he known his identity, he would have tried to make him prisoner! Howe also supped and remained over night, sleeping in the same bed occupied by the "rebel" the night before.

The close of the Revolution saw a revival of the iron industry, and a second forge was erected on the Valley Creek, three quarters of a mile farther down the stream. The building of a new dam raised the water above the level of the old site, and Mount Joy Forge became submerged. The later industry which sprang up on the new site was hereafter known as Valley Forge, and the old name was forgotten.

Amelia Mott Gummere. 


\section{Chester County, Later Delaware.}

At an early day between 1740 and 1750 there were two iron enterprises, a forge on Crum Creek, and a rolling and slitting mill on Chester Creek, in Thornbury township, where Glen Mills now stand, built by John Taylor. These were named Sarum Ironworks.

In September, I750, John Owen, Sheriff of Chester County, certified to the Lieutenant Governor that Sarum had been in operation until June of that year. After this time the British government had interdicted the further employment of rolling and slitting mills in the Colonies.

We cannot learn whether Mr. Taylor long obeyed this decree, but it is said that his works were carried on with energy until his death in 1756 .

Acrelius, writing about the time of Taylor's death, says: "Sarum belongs to Taylor's heirs, has three stacks and is in full blast."

Peter Kalm states that at Chichester (Marcus Hook), "They build here every year a number of small ships for sale, and from an iron work which lies higher up in the country they carry iron bars to this place and ship them." This "iron work" was probably Sarum.

John Taylor was the descendant of an English settler in the province. His rolling and slitting mill was the first in Pennsylvania.

Margaret C. Yarnall Cope. 


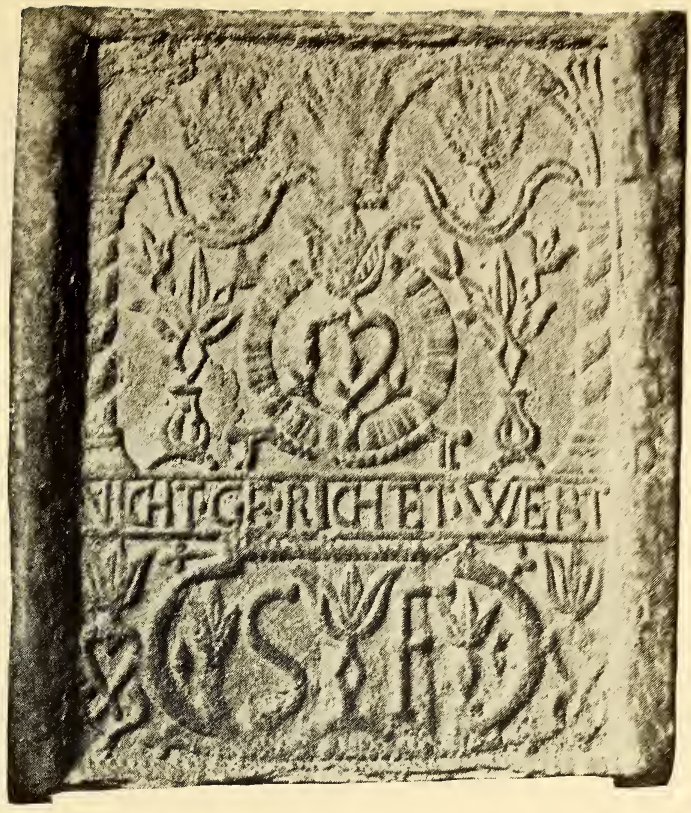

Stoveplate, about 1756 .

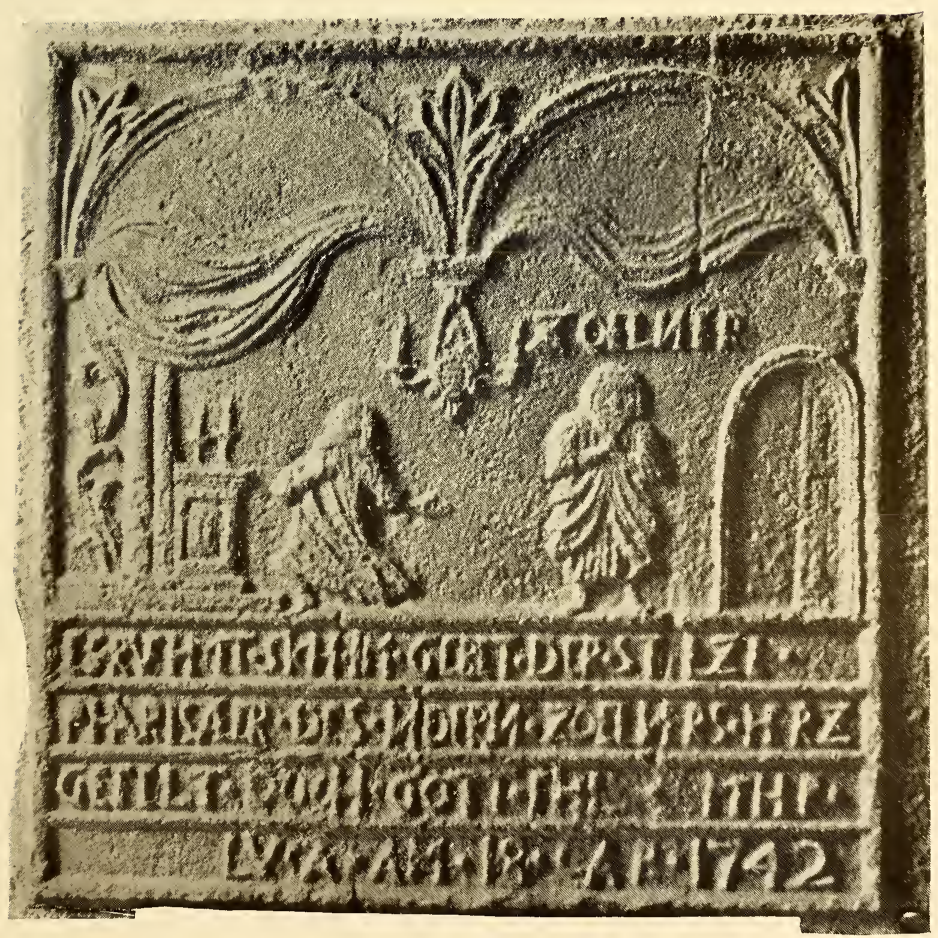

Stoveplate, 1742. The Pharisee and the Publican. 

Chester County, now Delaware.

John Crosby and Peter Dicks built this forge on Crum Creek near Chester, about I742. In Kalm's Travels into North America, I749, we find: "About two miles behind Chester I passed by an iron forge; the ore however is not dug here but 30 miles hence where it is first melted in the oven and carried to this place. The bellows were made of leather and both they and the hammers and even the hearth were but small in proportion to ours. All the machines were worked by water, the iron was wrought into bars."

Peter Dicks, a Friend, son of an early settler in Birmingham, married Sarah Powell in 1716 , and became a man of note in his neighborhood. In 1756 , he and three others vacated their seats in the Assembly at the request of the Council, in London, as it was desirable that there should be no Quaker in the Assembly during the War. ${ }^{1}$ He was also the owner of Peter Dick's Bloomary in York County.

${ }^{1}$ Hazard's Register, V, p. II 5. 


\section{LANCASTER County.}

Although the Province of Pennsylvania may not have boasted a Tubal Cain as early as Virginia, for so Colonel William Byrd facetiously dubbed Governor Spotswood, it appears that she outstripped the latter colony in the manufacture of bar iron which was made in Pennsylvania in the first quarter of the eighteenth century. In Colonel Byrd's entertaining account of "A Progress to the Mines," he recorded in September, I732, that as yet there was no forge erected in Virginia, adding that Mr. Chiswell, manager at one of the Virginia furnaces, had told him that "There was a very good one set up at the head of the Bay in Maryland that made exceedingly good work. He let me know that the duty in England upon Bar Iron was 24 shillings a Tun and that it sold there from Io to 16 pounds a Tun. This would pay the charge of Forging abundantly, but he doubted the Parliament of England would soon forbid us that improvement lest after that we shou'd go forth, and manufacture Our Bars into all Sorts of Ironware as they already do in New England and Pennsylvania."

Most of the early Pennsylvania furnaces had forges connected with them, and in some cases forges were built without furnaces, as were Pool Forges, Coventry, and Windsor Forges, all in Lancaster County.

During the summer of I9IO, an iron marker was placed near the high road at Coventryville, and a granite boulder in a field nearby, where are still to be seen the remains of an old forge. The tablet and boulder were erected by the Chester County Historical Society to commemorate the 
founding of Coventry Forge, which played an important part in the iron industry of Pennsylvania, being the second in the Province! ${ }^{1}$ To add a touch of picturesqueness to the historic interest of Coventry Forge Mr. George B. Johnson tells us that Mordecai Lincoln, ancestor of President Lincoln, was part owner and blacksmith at Coventry in $1725 .^{2}$

Of somewhat later date was Windsor Forges, which with its post office, Churchtown, is situated near the center of Caernarvon Township, in the northeastern portion of Lancaster County, bounded on the north by the Forest Hills and on the south by the Welsh Mountains. In among these mountains are the head-waters of the Conestoga, the Crooked Creek of the Indians of this region. As its name indicates, Caernarvon Township was settled by a colony of Welshmen, some of whom had emigrated to Chester Valley in I700. Tempted by a desire to further explore this beautiful and fertile region, these pioneers pushed on to Lancaster County; among them was John Jenkins, son of David Jenkins who came to Philadelphia from Wales in I 700 . John Jenkins and his family are said to have lived in a cave until he was able to build a block-house for their accommodation. Upon the Windsor Forges property the remains of this cave, or dugout, are still to be seen, and also a substantial little stone house which was once used for the storing of ammunition and food in case of an attack from the Indians. Mrs. John W. Nevin, a direct descendant of the first John Jenkins, in her sketch of Windsor Forges, tells of an Indian settlement under the brow of Maxwell's Hill between Church-

1 The writer had the pleasure of seeing both the tablet and the boulder in September, r9r3. A. H. W.

2 Address delivered at Phoenixville, July 8, rgro, upon early iron industries of Chester County and their relation to American Independence, by George B. Johnson, Esq. 
town and Morgantown. These were friendly Indians, she says, as her father, the Honorable Robert Jenkins, told her of hunting and fishing with them in his boyhood. This Indian settlement finally became a part of the farm of $\mathrm{Mr}$. Jenkins, and the ploughshare of the white man, now and again, turned up Indian relics. At a solitary place on the edge of the mountain a large stone was found, some years since, bearing a rough sketch of an Indian profile and tomahawk with the words "Wymus grave." "Most probably," says Mrs. Nevin, "Wymus was "the last of the Mohegans." "'

Nine years later Mr. John Jenkins sold this property to William Branson, of Philadelphia, who then owned Reading Furnace. This was December 28, I742, and soon after this, Branson built on this property the lower Windsor Forge, the date on the stone over the door was 1743 . The upper forge and the mansion house were built a little later. This house was substantially built, as its appearance to-day testifies, and not being disposed to belittle the importance of his possessions, Mr. Branson named his residence Windsor after the palace of the King of England. The old house has evidently been added to at different times, but a portion of the mansion belongs to the earliest period, and although both forges have long since disappeared, it is still in excellent condition. The lawn at the back of the house is terraced down to the Conestoga, making with its shrubbery, fine trees and parterres of old fash-

${ }_{1}^{1}$ Mrs. John W. Nevin, whose narrative has been quoted frequently in this sketch, said of it: "You may depend on this account being thoroughly accurate, as it is taken directly from the old account books. David Jenkins was my grandfather. My father, Robert Jenkins, inherited Windsor from his father. I was born there." The writer of this paper regrets that she has not been able to consult the "account books" of which Mrs. Nevin speaks. No one at Windsor Forges, at present, seems to know of their existence. 


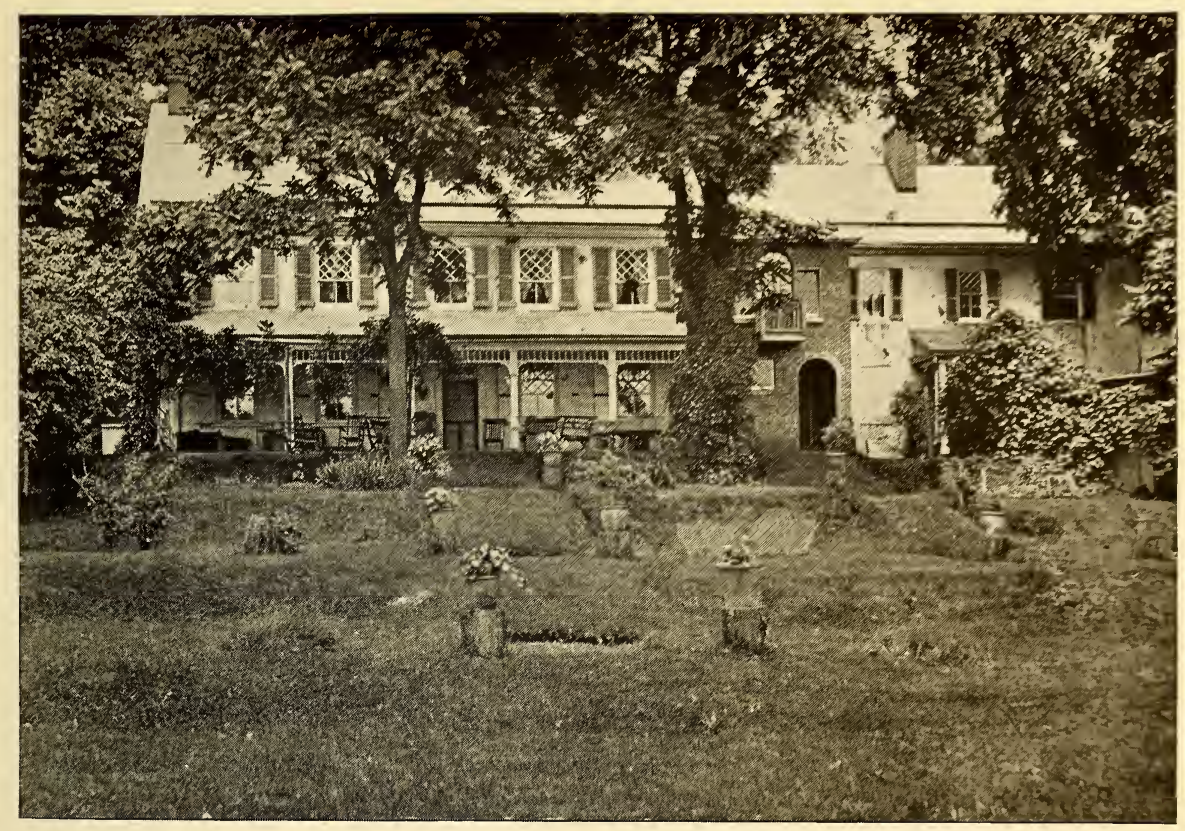

The Mansion, Windsor Forges.

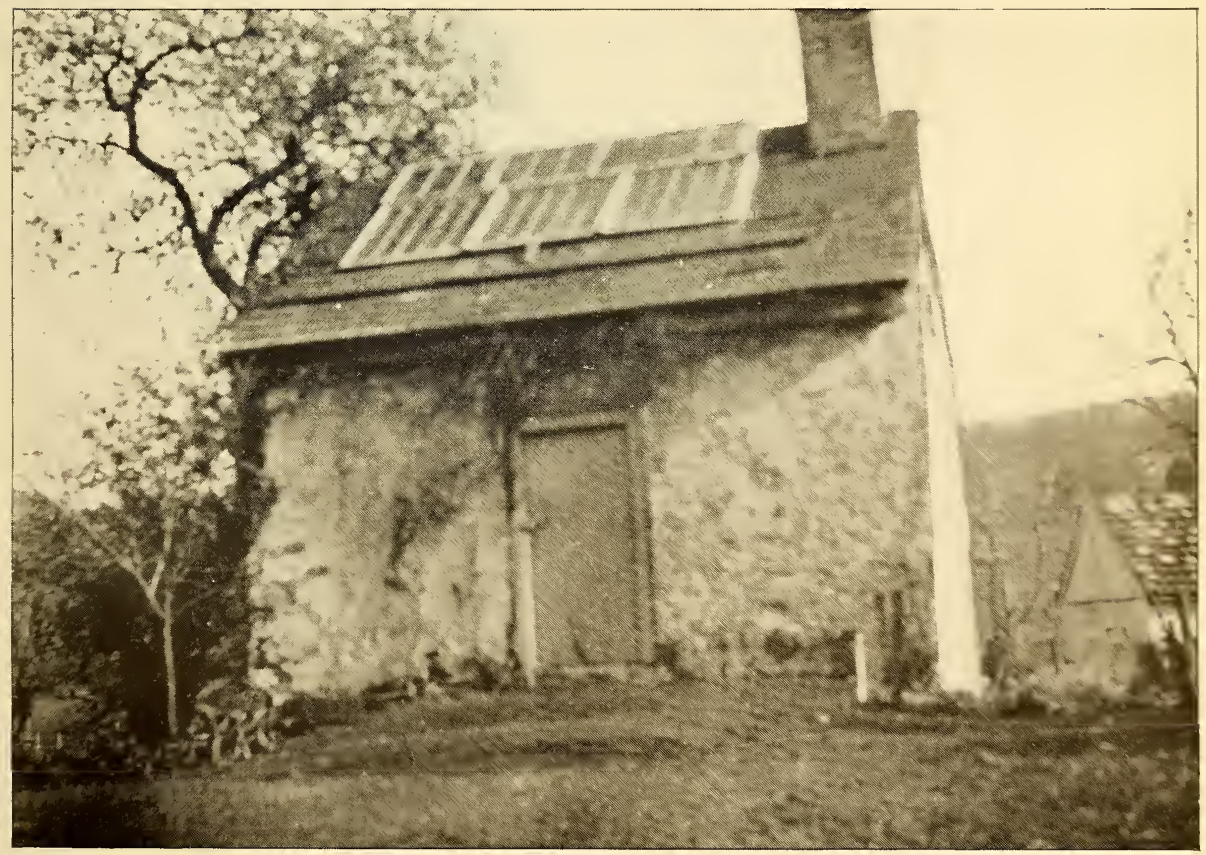

Stone house built at Windsor Forges for protection from Indians. 

ioned flowers a charmingly picturesque setting for the long, low mansion with its many latticed windows. This fine old house, with its extended facade which looks out upon the road, and its wide, hospitable doorway, is redolent of cherished memories of the past. These memories, the present owner of Windsor Forges has gathered together, and in some verses in which she laments the loss of a beautiful old tree on the lawn, she has taken occasion to celebrate the virtues of several chattelaines of the mansion house. ${ }^{1}$ Of Martha Armour of Pequea, wife of David Jenkins who worked the forges in I773, herself of Scotch Irish ancestry, and a valiant soul like many of her race, Miss Nevin has given a spirited picture.

\footnotetext{
"Martha Armour. She who put to flight

And foiled by strategy the Doanes one night.

"Coming one day from harvesting the hay

Men found her by the old well, where she lay

In a dead faint, her baby in her arms

Held tight, and screaming, full of vague alarms.

They 'brought her to,'

But all she knew was that she saw her child

Fall in the well. Then she went wild,

This only she remembered, nothing more;

But both were wringing wet, and bruised and sore.

How she got up none knew. Twas thought

Climbing, the baby in her teeth was brought."
}

With Mr. Branson were associated in his business at Windsor Forges, Samuel Flower, Richard Hockley, and Lynford Lardner. ${ }^{2}$ These three gentlemen afterwards

1 These verses and others usedin this paper were written by Miss Blanche Nevin, the well-known sculptress, who still lives in the beautiful home of her ancestors where she cherishes the traditions of the house, and exercises a hospitality like that of an earlier time.

${ }^{2}$ Mr. Lardner married Mr. Branson's daughter Rebecca, and lived in Philadelphia. Among other claims to distinction he was one of the founders of the first Dancing Assembly of that place. 
bought out Mr. Branson's interest and carried on the work at Windsor Forges for thirty years. In I773, David Jenkins, son of the original owner John Jenkins, bought a half interest in the company for 2500 pounds, and later when the war of the Revolution was imminent, the remainder, including the negro slaves and the stock used in the business, was sold to him for the sum of two thousand four hundred pounds. David Jenkins carried on the works successfully there until his death, in I779, when he left them and about 3000 acres of land to his son Robert Jenkins, including the upper and lower forges on the Conestoga.

The other sons of this family were William, an eminent lawyer, and David, a farmer. Both David Jenkins and his son Robert were members of the Pennsylvania Legislature, and the latter from 1807 to 18 I I represented his state in the Congress at Washington, or as his biographer expresses it more picturesquely, "sat in the halls of Congress." Mr. Jenkins' services were given during the important years before our second war with Great Britain, and in the heated discussions of that period his voice, it is said, was ever raised in the cause of justice and true patriotism.

There seems to have been an unwritten law in the Jenkins family that the eldest son of David should be Robert and vice versa, consequently we find Davids and Roberts alternating quite regularly in the ownership of Windsor Forges. The Honorable Robert Jenkins was in possession of the forges from 1799 until his death in I 848 , his son David in turn carrying on the works until his death in I 850 .

The establishment of iron furnaces drew to Caernarvon County, at an early date, a large population of Welsh workmen, who were skilled operators. The first David 
Jenkins who emigrated from Wales in 1700 married Rebecca Meredith of Philadelphia, whose ancestry is given in the following lines written by one of her descendants:

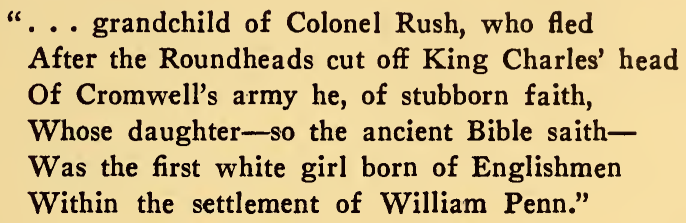

Sarah Aurelia Rush, said to be the first girl born in Philadelphia, was the mother of Rebecca Meredith who married David Jenkins.

The Honorable Robert Jenkins married Catherine $M$. Carmichael, daughter of the Rev. John Carmichael, of Chester County. The history of this lady, says $\mathrm{Mr}$. W. U. Hensel, is one of the unwritten romances of Lancaster County. ${ }^{1}$ The Rev. John Carmichael, who was pastor of the Presbyterian Church at the Forks of the Brandywine during the war of the Revolution, illustrated upon many an occasion a strength and loyalty of character which proved his daughter's most precious heritage.

While the patriot army was encamped at Valley Forge, during the severe winter of I 777 and ' 78, Mr. Carmichael preached to the soldiers whenever occasion offered. $\mathrm{He}$ also impressed upon his congregation the importance of giving everything at their command to General Washington's destitute army, himself setting them an example by stripping his own home of every commodity that could be spared. Upon one occasion Mr. Carmichael appealed to the women of his flock, insistently calling upon them

1 To the Honorable W. U. Hensel, whose learning and accuracy have made him par excellence the historian of Lancaster County, the writer is indebted for valuable data and suggestions during the preparation of this paper. 
to divest themselves and their children of all superfluities in the way of clothing and food for the benefit of the suffering soldiers at Valley Forge. To this eloquent appeal the women replied that they had given everything that they could spare except their flannel petticoats. "Cut them off and send them," was the resolute answer.

Although we may be at a loss to know what use soldiers could make of flannel petticoats, there can be no doubt of the patriotism and self sacrifice of a pastor and people who could so deprive themselves of the necessities of life, and as a proof that the devotion and patriotic service of this pastor and his flock were appreciated by the commanderin-chief, there has been preserved a letter from General Washington in which he thanks Mr. Carmichael and his congregation for their generous and timely donations of clothing and other necessities for the use of his army.

$\mathrm{Mr}$. Carmichael died while still in the prime of life, leaving his daughter Catherine, aged eleven, in the care of her uncle, the Reverend Robert Smith, D.D., pastor of the Presbyterian Church at Cedar Grove. After the death of her granduncle, Dr. Smith, in I793, Catherine Carmichael lived for several years with a relative at Strasburg, Lancaster County, and later receiving a cordial invitation from Mr. and Mrs. Buckley to make her home with them, she removed from Strasburg to the vicinity of Pequea. Mr. and Mrs. Buckley treated Miss Carmichael as their own daughter and in their hospitable home, which was the resort of many interesting people, she enjoyed a delightful social life. Here Miss Carmichael met one of the favorite habitués of the house, Mr. Robert Jenkins of Windsor Forges, whom she afterwards married. The marriage was from the home of Mr. and Mrs. Buckley in September, I799.

During her residence at Windsor Forges, Mrs. Jenkins 
took great pleasure in entertaining pious and learned men, and in elevating the character and improving the condition of her dependents. Her husband being engaged in cultivating the land and carrying on the forges, had necessarily a number of hands in his employ. In all his endeavors to do them good he was assisted by his wife's counsel and coöperation. The following anecdote, which illustrates Mrs. Jenkin's strength of character and high principles, was related by the Rev. John B. Laman in a sermon delivered at the funeral of this estimable lady, in September, I 856, at Cedar Grove Presbyterian Church.

"At this period and in this section of our country, vice and immorality stalked abroad in high and low places. The wine-cup and the gambling-table were the chief sources of amusement among many of the rich and influential; and the rum-bottle, among those in the humbler walks of life. In the midst of all this, what could a tender female do? With that energy and decision which had attended her during all the vicissitudes of the past, Mrs. Jenkins resolved to do what she could. An opportunity soon presented itself to call forth her efforts. The hands engaged about the farm and forges frequently came to the table at their boarding-house, in a state of intoxication. Mr. Jenkins, learning this fact, had endeavored to reform them in this respect, but the temptation was too strong to yield to his efforts. Mrs. Jenkins, at length, came to his assistance, and, with all the influence of female eloquence, portrayed to the offenders the injury they were doing to themselves, and the great sin they were committing against that kind Being whom she adored as her God. These admonitions proving ineffectual, she resolved to employ more decisive means. She obtained, through one of the domestics, the bottles in which the hands kept their rum. When the dining hour arrived that day, they were surprised and chagrined to see their bottles standing in a row upon the table, with their precious contents reflected through the glass. At this moment Mrs. Jenkins enters the room, and in her 
usual cheerful manner, says, that she is in possession of a number of bottles belonging to them, which she desires to restore to their respective owners, and hopes they will now come and take them. As none of the offenders were willing to acknowledge the ownership of the bottles, under the circumstances, she says: "They are now in my possession, and, as you will not take them, they are, of course, at my disposal.' She then conveys them to an open window, and strikes them against the wall until they fall in shivers upon the ground. The bottles being demolished and their contents thus destroyed, she turns to the men and says, in a mild but decided manner, "If they be replaced by others, they shall share the same fate."

In the winter of 1808 , while Mr. Jenkins was a member of Congress, Mrs. Jenkins accompanied him to Washington, and entered into the social life of the capitol. This was during President Jefferson's administration. To quote again from Mr. Laman:

"In the autumn of 1824 , during the triumphal passage of Lafayette through the country, he was invited by the inhabitants of Lancaster, Pennsylvania, to visit their place. Mrs. Jenkins met him at the baptismal ceremony at the house of George B. Porter whose child was named for the great man. Mrs. Jenkins, always interested in the religious views of famous people, took this occasion to inform Lafayette that she was the daughter of a clergyman who had taken a very active stand in the cause of liberty; she was accordingly delighted to hear the great man's freely expressed admiration for the American clergy and their high moral influence."

I have dwelt at some length upon the characteristics of Mr. and Mrs. Robert Jenkins because they are notable types, admirably representative of a distinct phase of Pennsylvania life in the last century, a life which no longer exists, which indeed was possible only in earlier days, before rail- 
roads, telegraphs, and telephones had brought the whole world in touch. In that earlier time, the iron furnace with its " big house," its workmen's houses, and several dependencies, formed a little world in itself. Indeed the relations then existing between the old iron master and his workmen were of a character that would be little understood by the operator in iron and steel industries of to-day. The workmen's homes were erected on "the Bank" near the furnace, that being the name commonly given to this settlement whether really on the bank or by the side of a level road. The workmen's houses at Windsor, of which two are still standing, were built near the winding Conestoga. In these settlements they lived their lives and brought up their families, father and son working for the iron master and his son, and often entertaining for them an affection and loyalty very like that of the retainer of an older time.

Only those who have lived at an old iron furnace have any adequate conception of the almost feudal relations existing between the employer and employed. . It was a condition of interdependence with an underlying sense of protection and friendliness. If these workmen had been called upon to arm themselves and go forth to fight for their chief, as in feudal times, they would doubtless have gone without a murmur. As it was, the only lists that they were called upon to enter were to be found at the polls. At election times the hands were all sent in huge wagons to vote for whatever candidate represented the protective tariff, the fetish of the iron industry in the early years and in the middle of the last century, as it has been in later times. Even if the farmers in the surrounding country represented other shades of political belief, the hands at the furnace were true blue to a man, not in any sense feeling that they were "taking orders" from their employer, but rather as reflecting the opinion of one whom 
they looked up to and considered much wiser than themselves. In material things these work people were childlike in their dependence upon the "big house," as the proprietor's mansion was called. Their supplies came from the store, which was not called the company store in those days, but simply the store, and was an actual necessity as the nearest town and base of supplies was often separated from the furnace by from twelve to twenty miles of heavy clay or mud roads. To the wares in this store the proprietor, in many cases, gave his personal supervision, and there being no middle man the workman whose flitch and flour, coffee and sugar, did not please him had only to speak to the manager or to the iron master himself.

In some of its phases the life at the old iron furnaces of Pennsylvania was like that upon a southern plantation. Indeed, the early iron masters frequently spoke of their estates as plantations, including as they did many acres upon which, in early times, slaves were employed. The old account books of Windsor Forges give a long list of slaves employed at the works and upon the farm. These slaves, who were usually Guinea negroes, were frequently named from the place where they were bought, as "Philadelphia Jim," "Lunnon Boat" and "Slave Boat Swain," names indicating purchase from a slave ship. Other negroes were given or retained such odd names as "Quash" "Cooba" and "Negro Mig." In the second generation, the classic names of Greece and Rome prevailed and "Pompey," "Caesar," and "Scipio" were among the names at Windsor Forges. The women slaves were often given names immortalized by English poets in addresses to their mistresses, as "Chloe," "Phyllis," "Priscilla," "Clarissa," "Diana" and "Venus." By the laws of Pennsylvania there was gradual emancipation for these slaves, their children served until they were twenty-eight, 
the children of the third generation were born free but were bound to the former owner's family until they were eighteen or twenty-one. Every family had at least two of these servants who were usually faithful and took great pride in the members of the family to which they belonged, and by whom they were generally treated with great kindness. One of the oldest inhabitants of Churchtown recently recalled a wedding at Windsor, with "Quash" as the groom, when the fair bride, whose name she forgot, was arrayed in a white frock with low neck and short sleeves, a wreath of marigolds adorning her head. This wedding was attended by members of the Jenkins family who provided a generous collation.

In cases of illness the "big house" was invariably applied to, and severe indeed were those ailments which the iron master's wife was not considered able to relieve with the remedies that she was always expected to have within reach. One of my own earliest recollections is of hearing the wives of two iron masters comparing notes with regard to their medical practice among the furnace hands. One of these lovely ladies, whose face rises before me as I write, had supplied herself with Dr. Hering's book, and a box of tiny bottles warranted to cure all ills to which the flesh is heir, with these, she was wont to say that she practiced with considerable success. The other lady, being the daughter of a physician of the older school, adhered, in the main, to the more heroic system of her fathers. Both, being wise women, used, in the treatment of the cases brought to them, their native wit and common sense in a larger measure than the drugs in their medicine closets.

After the death of the Honorable Robert Jenkins the work at the forges at Windsor was carried on by his son David Jenkins, who was, like his father, a kindly and benevolent employer, deeply interested in the wellfare of 
his workmen and their families. Mr. David Jenkins was not married, and after his death in 1850 the work at Windsor Forges seems to have been abandoned chiefly on account of sharp competition in the iron business, the lack of facilities for transportation, and the more modern machinery with which some of the neighboring furnaces were equipped. In addition to these causes, the scarcity of wood, which seriously interfered with the iron industry in certain localities of Pennsylvania, may have had much to do with the abandonment of the forges at Windsor. The charcoal used in these old furnaces and forges naturally led to the despoiling of large tracts of woodland. At one Pennsylvania furnace, where the writer of this little paper spent many years of her childhood, the coal for the furnace was charred in the South mountain and carted across miles of bad roads to the furnace, which was then surrounded by arable land. This carting of the charcoal, of course, added materially to the expenses of the making and moulding of iron.

In the course of years Lancaster, which was at one time a great iron-making county, became one of the richest of Pennsylvania's agricultural counties. The Indian trails, over which the German, French, and English artisans transported their iron upon pack horses to the neighboring forges, became in time the high roads over which grain was conveyed to the commercial centers of the Middle States. With the abandonment of the old charcoal furnaces and forges there passed away a picturesque and individual phase of the rural life of Pennsylvania.

Anne Hollingsworth Wharton. 


\section{OLEY FORGE.}

\section{Philadelphia now Berks County.}

When the forges built on the Manatawny Creek had been in operation a few years, and had demonstrated that there was "money in it" for the canny investor, Philadelphia capital began to flow in that direction-and in I744 one John Ross, "Gentleman," formed a company and took into partnership two men from the iron region, John Yoder and John Lesher of Oley. About ten miles from the confluence of the Manatawny with the Schuylkill was a little hamlet called "Oley Churches" and the place selected for the new Forge was about one quarter of a mile south of the quaintly named village. They purchased from Sebastian Graeff a tract of one hundred and ninetyseven acres situated along the Manatawny Creek, adjoining lands of Robert Stapleton and John Yoder, and upon the "Great Road" leading to Philadelphia. Here they erected a forge for the purpose of "manufacturing pig metal into bar iron," constructed a water pond, water courses and the necessary buildings, and they also looked to their future supply of wood for charcoal by purchasing warrants for taking up lands on the adjacent hills.

In I 750 John Yoder sold out his one-third interest to John Lesher, and Lesher and Ross kept their respective holdings until the death of the latter. John Lesher ( I I I-I 794) was born in Germany and came to Pennsylvania in 1734. Settling in Berks County near the Oley Churches, he became one of the strong men of that neighborhood and for fifty years was identified with iron inter- 
ests. He represented the county in the Constitutional Convention of $\mathrm{I} 776$, and served in the General Assembly from I 776 until I 782 . While in the Convention he was a member of the important committee which prepared and reported the "Declaration of Rights." During the Revolution he acted as one of the commissioners for purchasing army supplies. Suffering, as did many others, from the unceremonious manner in which supplies for the army were demanded and taken, John Lesher wrote to the Supreme Executive Council on the 9 January, I778 :

"I conceive it to be my duty to acquaint you that I am no more master of any individual thing I possess! for besides the damages I have heretofore sustained by a number of troops and Continental wagons in taking from me 8 tons of hay, destroyed apples sufficient for Io hhds. of cider, eating up my pasture, burning my fences, etc. and two beeves, I was obliged to buy at I sh. per lb. to answer their immediate want of provisions, and at several other times since, I have supplied detachments from the army with provisions. There has been lately taken from me I 4 head of cattle and 4 swine. The cattle at a very low estimate, to my infinite damage, as they were all the beef I had for my workmen for carrying on my iron works.

"I had rather delivered the beef and reserved the hides, tallow, etc., but no argument would prevail! all must be delivered to a number of armed men at the point of the bayonet. As my family, which I am necessitated to maintain consists of nearly thirty persons, not reckoning colliers, wood cutters, and other day laborers! My provision and forage being taken from me, my forge must stand idle! My furnace (which I am about carrying on) must of consequence be dropped! which will be a loss to the public as well as myself as there is so great a call for iron at present for public use, and some forges and furnaces must of necessity fail for want of wood and ore. The case in this neighborhood is truly alarming when the strongest exertion of economy and frugality ought to be practiced by all 
ranks of men! Thereby the better to enable us to repel the designs of a daring Enemy who are now in our land.

"It strikes me with horror to see a number of our own officers and soldiers wantonly waste and destroy the good people's properties by such conduct. They destroy the cause they seek to maintain. Instead of judicious men appointed in every township, or as the case may require, to proportion the demands equal according to the circumstances of every farmer and the general benefit of the whole, these men under the shadow of the bayonet and the appellation 'Tory' act as they please. Our wheat, rye, oats and hay taken away at discretion and shamefully wasted and our cattle destroyed. I know some farmers who have not a bushel of oats left for seed, nor beef sufficient for their own consumption, while others lose nothing -as a man who had roo head of cattle lost not one. Such proceedings I think to be very partial. Many farmers are so much discouraged by such conduct that I have heard several say they would neither plow nor sow. If this takes place the consequence may be easily foreseen, unless some speedy and effectual method be taken to put a stop to such irregular proceedings, and encouragement and protection extended to the good people of the Commonwealth. I shudder at the consequences. I humbly submit the whole to your serious consideration."1

John Ross was a rather picturesque character, an officer of the King and a half brother of George Ross, Signer of the Declaration of Independence. Graydon says of him: "Mr. John Ross, who loved ease and Madeira much better than liberty and strife, declared for neutrality, saying, that let who would be king, he well knew that he would be a subject."

In the settlement of his estate litigation arose with Lesher, and while this was going on Lesher sold out his two-thirds to his son Jacob, an iron master, and his sons-in-

${ }^{1}$ M. L. Montgomery's History of Berks County in the Revolution. 
law John Potts, and Jacob Morgan. After a number of changes, Frederick Spang of Oley became the owner in I794, and he and his descendants carried on the iron business here for seventy years; the plant being known as the Spang Forge.

Before the country was cleared of its forests the Manatawny and its affluents had a sufficient volume to operate numerous mills and small factories, some of which are still carried on. The stream at Oley Forge afforded a strong water power, the dam covering about forty acres. This perhaps explains why Oley Forge had a continuous history and was in active operation for one hundred and twenty years. ${ }^{1}$

Mary E. Mumford.

${ }^{1}$ M. L. Montgomery, History of Berks County. 


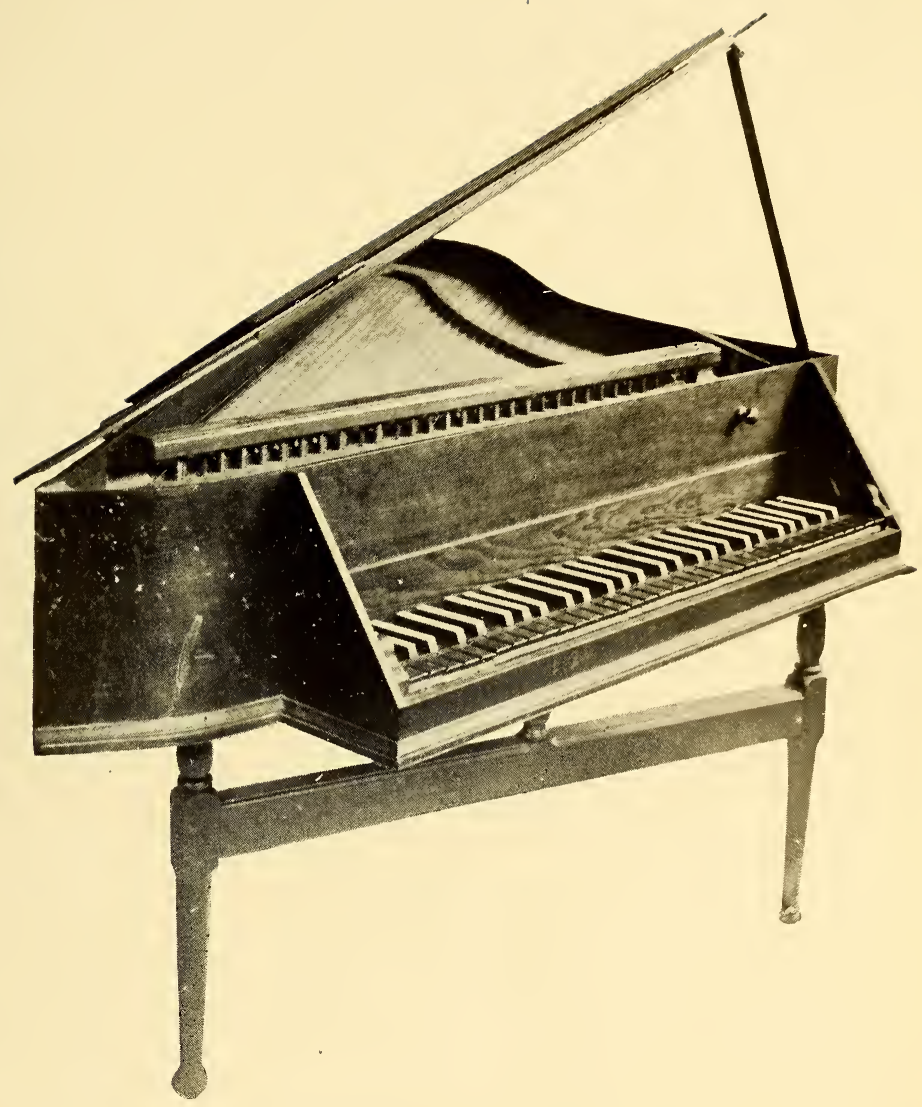

Harpsichord of H. W. Stiegel, i765. Presented by the family of Mrs. Henry Morris, his great-granddaughter, to the Historical Society of Pennsylvania. 



\section{CHARMING FORGE.}

\section{Berks County.}

A forge was built on Tulpehocken Creek, some miles north of Womelsdorf in 1749 , by John George Nikoll, a hammersmith, and Michael Miller. Calling it Tulpehocken Eisenhammer, they immediately " at their joint expense erected an Iron work, or Forge and Dam, and dug a Race or water-course, and made other great improvements for the commencing of forging and the manufacturing of iron."

A worn account book, alphabetically divided, in the Mss. of the Historical Society of Pennsylvania has this inscription, in German writing; "Tulpehocken Eisenhammer, I 757, Michael Reis and [?] brenner in company." Another, similar, dates back to I754, and a third, dated I 760 , has the name Stein added: a possible partner.

About 1762 Henry William Stiegel bought lands adjacent, from Michael Reis and Garrett Brenner, and in February, I763, he bought an undivided half of the Forge with appurtenances and eight hundred and fifty-nine acres of land from C. and A. Stedman. ${ }^{1}$ By 1770 he had added to his holdings of land here so largely that he owned thirty seven hundred acres.

Stiegel called this Forge, Charming; the name being simply descriptive of the great natural beauty of the neighborhood. In his desire for land he more than once exchanged tons of iron bars for coveted acres. An undoubt edly industrious man, able and hopeful, he was a stimulant in many ways to his contemporaries. His workmen, who

1 Ledger of Charming Forge, at the Historical Society of Pennsylvania. 
were always well treated, loved him,-and tried, as they could, when his evil days came, to help him. The musical interest was great, between them. One can imagine the pleasure of being summoned from the heat of forge and furnace, to welcome the Master on his return home by "playing on instruments." And these same instruments seem to have cost something. In a valuation of his possessions, in his own handwriting, one finds:

"By Musical InstrumentsHouse Furnitureand-

"My clear estate after deduction of debts is worth this day, July I, I 763 , -

Of all these musical possessions two only seem to be extant. In one of the Museum rooms of the Pennsylvania Historical Society is a plain oddly shaped harpsichord on a curious trestle support. The shape really is not so odd, as it strongly resembles that of a "Baby grand," and the smooth brown wood shows no breaks or marks. Purchased by Stiegel about one hundred and fifty years ago, it became later the property of his daughter Elizabeth who married William Old, son of James Old, the noted ironmaster. Descending finally to her granddaughter Caroline Old, who, in I830 was married to Henry Morris, so well known to Philadelphians of a generation or so ago, it rested for many years at Solitude the charming "country in city" home of Mr. Morris. At Mrs. Morris's death, I889, the harpsichord was given by the family to the Historical Society. A Stiegel guitar or lute also the

\footnotetext{
${ }^{1}$ Ledger, Elizabeth Furnace 1762-65, Historical Society of Pennsylvania.
} 
property of Mrs. Morris, is now in the possession of her daughter, Mrs. James Wood of Mount Kisco.

On July, I, I 763, he values his Manheim town and lands, "Io lots Heidelberg and others," enumerated, at $£ 4540$.

Two or three of Stiegel's own entries in the day book are interesting: as, - a long account with "Curtis Grubb," in I773: "By Pigg Mettal." And, much later, when he no longer owned the forge,-in I779, "Daniel Benezet's Account, lent by Mr. George Ege, pro memoria,

Bonds and Mortgages

To 4 years interest on same

Ditto, bill the Day (illegible)

Ditto, to September I779, Interest
L $\quad$ S $\quad d$

3000

720

540

900."

By 1772 his financial embarrassments were beginning to crowd around him. In a Day Book of Charming Forge we find an entry showing the lease on May I, I772, of "one full undivided half part of Charming Forge with all the lands and estates thereto belonging for a yearly rent to Mr. Paul Zantzinger . . . and whereas said Paul Zantzinger and George Ege by another instrument in writing hath mutually agreed to carry on the said Forge in Company, preparations were made .... for accounts of said company the transactions and accounts of which are as follows." 1

By I775, possibly earlier, George Ege was the sole possessor of Charming Forge, as the inscription in one of the Day Books in the Pennsylvania Historical Society shows:

"Charming Forge

Day Book, May I ${ }^{\text {st }}$ I 775

George Ege Proprietor."

1 See Elizabeth Furnace. 
The George Ege here mentioned, was Stiegel's nephew by marriage, the son of Michael Ege, who served in the French and Indian Wars, and grandson of Bernhard Ege, who came to this country in 1738 from Wurtemburg. On the death of George Ege in I 759 his widow and two sons, George and Michael, were most hospitably taken into Stiegel's family at Elizabeth Furnace, George then being eleven years old. These boys were carefully trained by Stiegel in the best methods of iron making, and in after years did his teaching great credit, becoming, the one in Berks county, the other in York and Cumberland, two of the greatest iron masters in the country.

In July, 1776, the Executive Council of Pennsylvania passed a resolution authorizing the employment of Hessian prisoners of war, at Lancaster and Reading, and in the furnaces of Chester, Lancaster and Berks counties, which were casting cannon and shot for the government. Early in $1777 \mathrm{Mr}$. Ege purchased from Congress the services of thirty-four Hessian prisoners for the purpose of cutting a channel through a bed of rock to supply his slitting mill with water power. The mill race, about twenty feet wide; was cut through a mass of solid slate rock as smoothly as if done by a broad-axe. It was used until 1887 when the forge was abandoned. ${ }^{1}$ For the services of these channel cutters he allowed the United States Government, November 5,1782 , the sum of $£ 1020 .^{3}$

Augusta M. Longacre.

1 Pennsylvania, Colonial and Federal, by Jenkins.

2 Ibid. 


\section{ELIZABETH FURNACE.}

\section{LANCAster County.}

About 1750 a small furnace was built by John Jacob Huber, a German, on a tributary of Conestoga Creek, near Brickersville, in Lancaster county. An earlier date might possibly be given, as, in Wast Book $A$, Elizabeth Furnace, $1756^{1}$ there is an entry evidently taken from another book, - "Began to take the hearth out of the Furnace, Oct. 6, I 746."

Of Huber, personally, little is known, except that on a stone in this furnace he had these words inscribed:

\section{"Jacob Huber, der erste D'eutsche Mann Der das Eisenwerk vollführen Kann."}

One other title to fame he has:-that, on the $7^{\text {th }}$ of November, 1752, his daughter, Elizabeth, was married to Heinrich Wilhelm Stiegel. This small furnace had the fortune to be owned by two men, Stiegel and Robert Coleman, whose names, for different reasons, are to-day perhaps the best known among the earlier Pennsylvania iron masters.

Many tales and traditions have come down to us, of the prosperities and adversities of Henry William Stiegel, popularly called Baron, one of our few upper class German settlers. Evidently an interesting and impressive personality, he, for years supplied his simple country neighbors with dazzling glimpses of the "pride of life"; and it is small wonder that they should consider him an amazing and marvellous creature, of a kind not usually abounding

${ }^{1}$ Manuscript Collections, Historical Society of Pennsylvania. 
among Pennsylvania Germans. His later misfortunes have overshadowed the remembrance of his follies, and with the latent perfume of the yearly Feast of Roses, his name seems to come softly and pleasantly down to our time.

Henry William Stiegel came to Philadelphia in August, I750, by the ship Nancy, from Rotterdam and Cowes. He was then about twenty years old. Sifting the evidence for and against the traditional title of Baron, which personally he does not appear to have claimed, it is possible that he came from Mannheim, Baden, Germany, after having quarrelled with his family; a proof of this is, that while in after life, he went once or oftener to England, he seems to have made no effort to go to his early home. $\mathrm{He}$ brought with him, to Pennsylvania, a considerable sum of money. The estimate of one writer, that the sum was $£ 40,000$ is questionable, even when compared with Stiegel's lavish outlay later, in lands and buildings. ${ }^{1}$ If , he were of noble birth he must have changed his name, as "Stiegel" is not to be found in the nobility lists of Germany. He may have belonged to the Stengels. An interested investigator, Dr. J. H. Dubbs, found that a young Stengel had left Mannheim for America shortly before the date of Stiegel's landing here, and that a younger line of the Stengels belongs in Baden,-their ancestral home, Strengelhof, being near Mannheim. Once, in America, Stiegel signed his name "Henrich (sic) von Stiegel," to the constitution of the old Lutheran Church in Brickersville. Ordinarily, his signature was simply Stiegel, or Henry William Stiegel. However this may be, his birth, noble or simple, was not a matter of great moment to him, in his stirring life in America. Of good family he undoubtedly

1 C. F. Huch, Mitteilungen Des Deutschen Pionier Vereins von Philadelphia, Fünftes Heft, I907. 


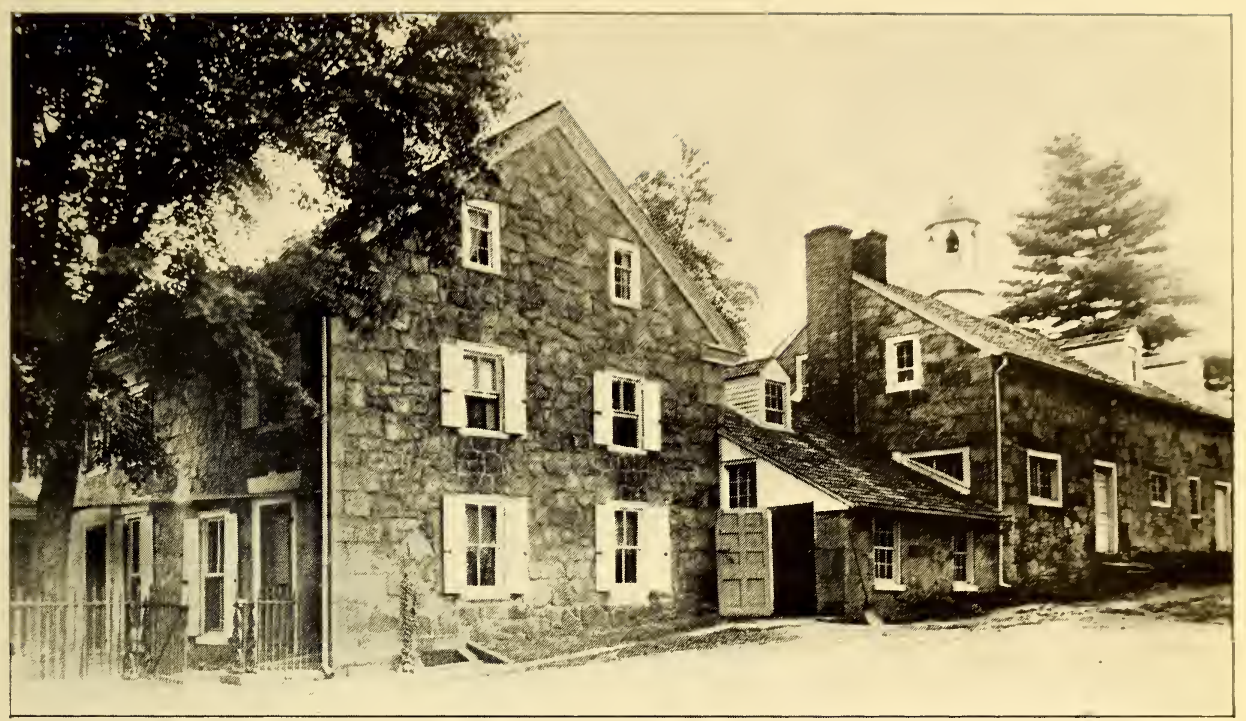

House of Henry William Stiegel, Elizabeth Furnace. His offices at rear of house.

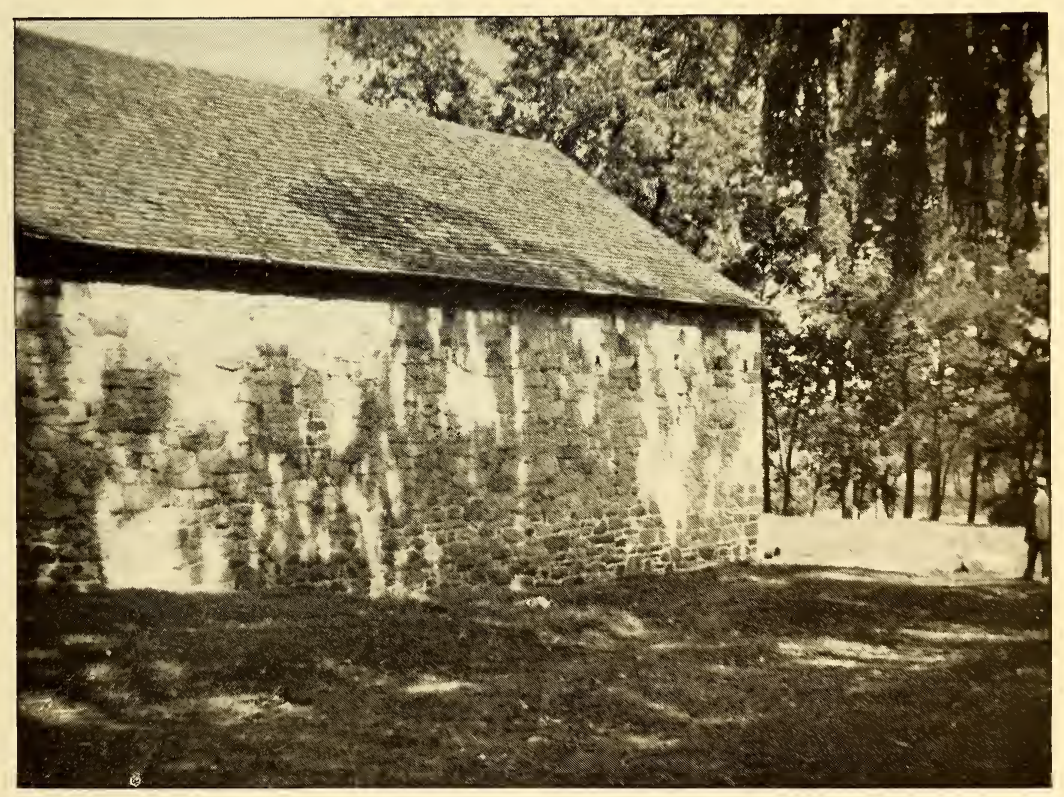

House where the charcoal was stored at Elizabeth Furnace. 

was. He had had an excellent education, and was a man of cultivation and taste: this is shown in his technical and musical knowledge, ${ }^{1}$ and later in his mode of life and the equipments of his residences. Of distinct capacity and enterprise, he was also sanguine, credulously trustful, and with a great love of ostentatious living. These latter tendencies, together with outward circumstances utterly beyond his control-for who could foresee the Revolutionary War?-brought on his mortifying failures.

Stiegel's married life, with Elizabeth Huber, was happy and short. In 1757 he bought Huber's furnace, and built on the old site a much larger one, naming it for his wife, Elizabeth. She died in February, 1758, leaving two daughters, Barbara and Elizabeth.

There is in existence a stove plate ${ }^{2}$ decorated with Heart and Tulip, bearing the inscription:

\section{H. William Stiegel und Compagni for Elizabeth 1758 .}

That the words "for Elizabeth" are to honor the memory of his dead wife, one can hardly doubt; even though within the prescribed year of mourning after her death he should have paid her that subtlest of all compliments according to some philosophers, a speedy remarriage, and with another Elizabeth-Elizabeth Wood, or Hölz, of Roxborough, near Philadelphia. This marriage is said to be on record at St. Michael's Church, Germantown. They had one son, Jacob.

In buying Elizabeth Furnace, Stiegel had partners; John Barr and the Stedman brothers, Alexander and Charles; the latter of Canadian origin, being well-to-do merchants in Philadelphia. An unfortunate connection this seems to

1 C. F. Huch.

2 In collection of G. H. Danner, Manheim, Pa. 
have been. In his transactions with the Stedmans, through a number of years, their business shrewdness was greatly superior to his. They apparently tied him up with contracts in which the advantage was generally on the Stedman side, while Stiegel's industry and enterprise were no match for their clever astuteness. They were presumably men of importance in Philadelphia, as their names, as also others of the early iron masters, are on the Assembly lists of the time.

Another hindrance to Stiegel's permanent success, was the buying of land, in unnecessary quantities. Evidently, he brought with him from Germany traces of the tendency called there Erd-hunger; and this adding of acre to acre was one of the causes of his financial embarrassment and downfall. For a period of at least ten years, however, he prospered greatly. A sister of Stiegel's second wife, named Anna Catherine Hölz, had married George Michael Ege. At the latter's death in 1759 , his widow and two sons, George and Michael, were taken into the family at Elizabeth Furnace. Stiegel, the guardian of his nephews, educated them, and had them trained in the rudiments of iron making, in which they became later, experts. Prosperity marked Elizabeth Furnace from I 760 on. Seventyfive persons were employed, and, near by, twenty-five workmen's houses were built, some of which are still there. In autumn and winter, many of the workmen were busy felling wood in the neighboring hills, for charcoal burning.

A list of all Stoves cast at Elizabeth Furnace, r77 I, includes

Bigg Io plate

Small $\mathrm{d}^{\circ}$.

Bigg 6 plate

Middle ditto

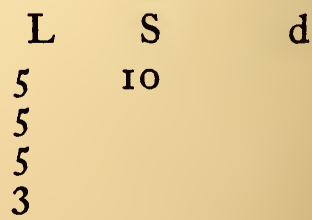




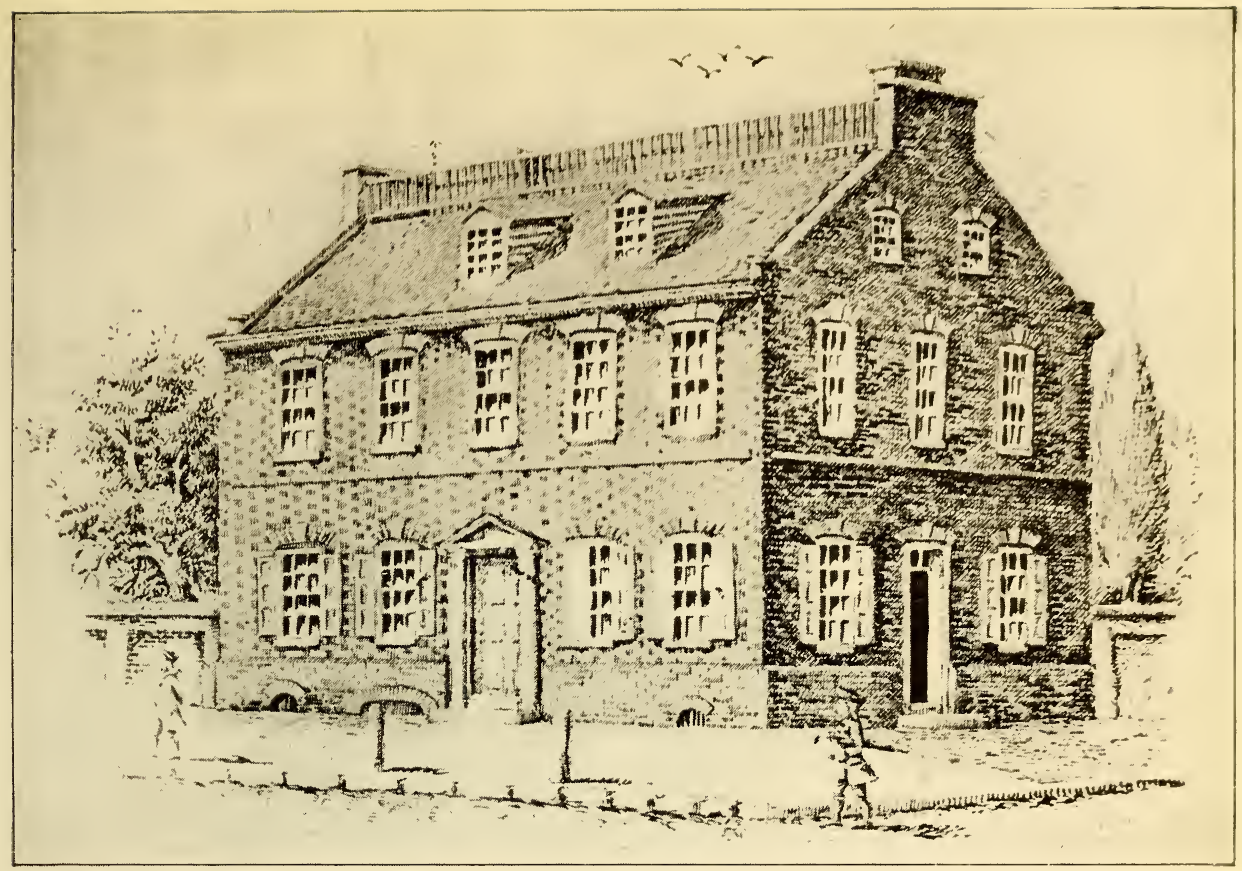

Mansion of H. W. Stiegel, Manheim.

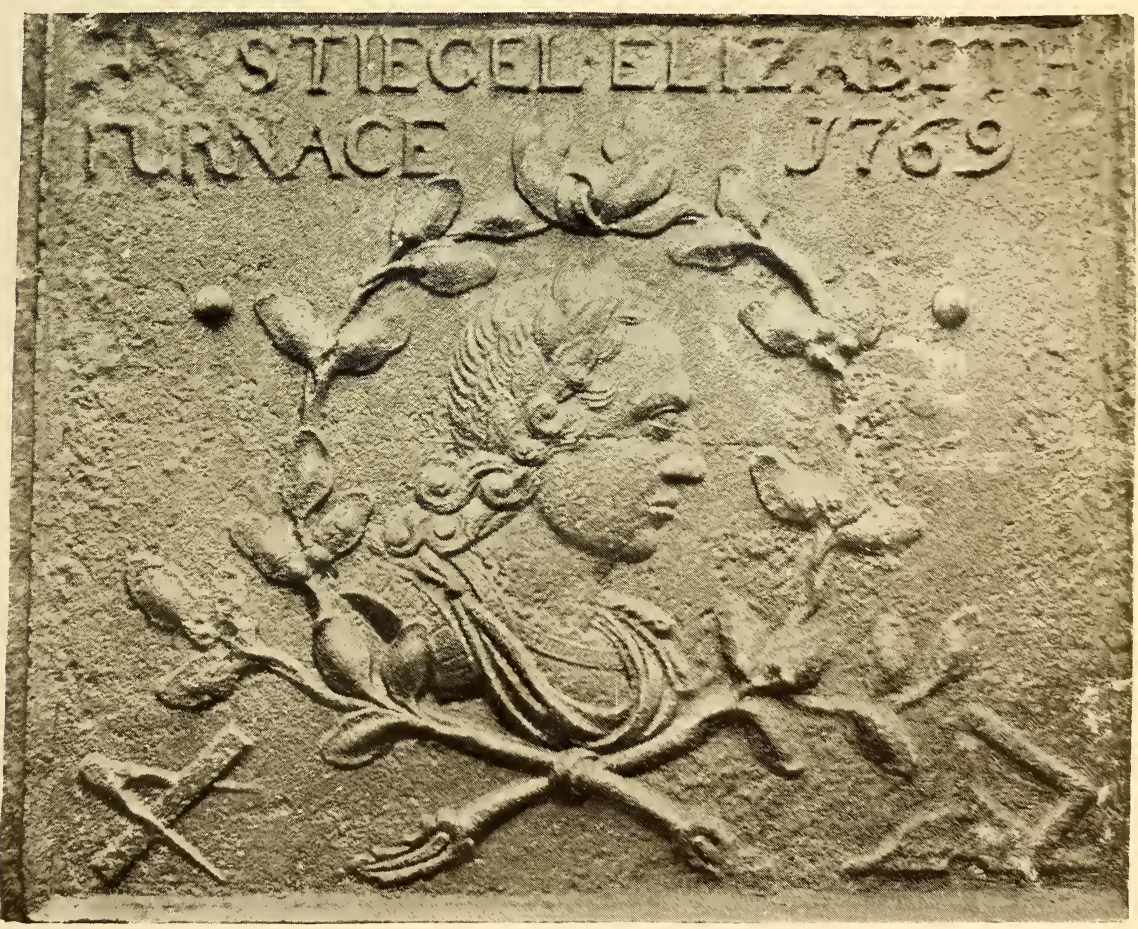

Stoveplate, called the Medallion plate, Elizabeth Furnace, 1-60. Owned by Mr. M. H. Danner, Manheim. 

Small ditto

Bigg 5 plate

Middle ditto

Small

Moravian Stove

An open 6 plate half Stove

$\begin{array}{ll}\text { L } & \text { S } \\ 2 & 5 \\ 5 & \\ 4 & \\ 3 & \\ 3 & \\ 4 & 10^{1}\end{array}$

d

On the 20 September, 1762 , Stiegel bought two hundred and forty three acres of land from $\mathrm{C}$, and A. Stedman and speedily laid out a town, calling it after his supposedly native place, Manheim. All that had stood there before this ambitious planning, were two little block houses; by Stiegel's energy and exertion, however, in a short time a number of buildings: were erected (sold on the ground rent plan), and early in 1763 he began to build his own mansion. This not very imposing "castle" as the neighbors called it, was a strong, well-built brick house, forty feet square. The bricks were possibly imported, but certainly were brought from Philadelphia in his own wagons. ${ }^{2}$ The interior ornamentation, tiles and furnishings, probably came from England, as Stiegel was there on business in that year. One of these blue tiles is to be seen at the Historical Society of Pennsylvania and at the Museum of Mr. G. H. Danner in Manheim are many memorials of Stiegel. It is a curious thing that no likeness of this widely known man is in existence, or, if in existence, it is practically unknown. One large room in his house was fitted up as a chapel where he held religious services for his family and workmen, and also for the neighbors, who came, many of them, on foot, and often from a distance of ten or more miles.

Early in 1763 Stiegel bought lands adjacent to Tulpe-

${ }^{1}$ Ledger of Elizabeth Furnace, in Manuscript Collections, Historical Society of Pennsylvania.

2 C. F. Huch. 
hocken Eisenhammer, near Womelsdorf in Berks county. On the fifth of February, I 763 , he bought an undivided half of that forge, with eight hundred and fifty nine acres, from C. and A. Stedman. He later added largely to these holdings of land, and called the Forge Charming. The Stedmans retained the other half of the property.

Extravagant, kindly and sanguine, Stiegel's life for some years now was outwardly prosperous, and his period of ostentatious living came to its height. He provided his German workmen with musical instruments, which, with the inborn musical talent of the race, they used with skill and pleasure. The story goes, that when he returned to Manheim from a journey, in his coach and four, a cannon was fired, at some distance from the house, and, on arriving he was greeted by favorite airs, played by his workman band, gathered in the large balcony on the roof of the mansion. An attractive picture, if somewhat vainglorious. He built also, a tower, on a hill not far from Elizabeth Furnace, called to this day Tower or Cannon Hill, which, except the foundations, was of heavy timber, fifty feet at base, seventy-five feet high and ten feet square at the top. It contained a number of rooms. He built this, Heaven alone knows why, unless possibly to entertain friends, or to have a retreat for himself; as, with all his open heartedness he was suspicious of his surroundings, fearing robbery, or danger to life. ${ }^{1}$ On this structure, he had one of his favorite cannon for salutes.

In 1772 he gave to the Lutheran congregation in Manheim a piece of ground on which to build a church, taking the sum of five shillings to make the transaction legal, and exacting an annual rental of " one red rose, when the same shall be legally demanded." After disuse for many years,

1 Ege Genealogy. 



$$
\text { 自 }
$$


this custom was taken up about twenty-five years ago, and on the second Sunday in June, now, the "Feast of Roses" attracts crowds to the "Baron Stiegel Memorial Church" (erected in 1857), in whose tower a peal of ten bells has been dedicated to his memory. At these services, a descendant of Stiegel's receives the red rose, addresses are made, and the chancel is often filled with red roses, dropped there by the audience, individually, as a tribute.

First in Pennsylvania to attempt the making of flint glass, he did more than attempt, he succeeded; and for ten years his factory made bottles, tumblers, wine glasses, vases, jugs, dishes, playthings and colored glass, supplying the needs of the distant colonies as well as his own. Bearing the general title, "American Flint Glass," there are three old account books in the manuscript collections of the Historical Society of Pennsylvania. The earliest one is inscribed "Ledger A. No. I. Begun the 6th of October, I764, for Manheim Glass House, by Henry William Stiegel." This is probably the date of the formal opening of the works. As usual, in building this factory his ideas were bold, and too great for his pocket. On the corner of Charlotte and Stiegel Streets, in Manheim, he erected a brick building so large that a double team could drive in and turn around. The height, to the top of the dome was one hundred feet.

To quote an authority, Dr. Edwin Atlee Barber: "He secured skilled workmen from the best factories of Europe, and the wares produced after the most approved methods of the period, found their way into the homes of the wellto-do people of that day, and many examples are still preserved. Improvements were made in the manufacture from time to time, as is shown by an original agreement dated June 4, I773, in possession of Mr. George $\mathrm{H}$. 
Danner of Manheim, between Henry William Stiegel, owner of the American Flint Glass Manufactory and Lazarus Isaac, glass cutter of Philadelphia, described as 'cutter and flowerer' who was to receive wages of five pounds ten shillings a month. By the term 'cutter' we do not understand that this workman actually cut and polished glass in the modern sense, as no examples of true cut glass have come to light, which could be attributed to this factory, but numerous specimens of blown glass, ornamented with surface etched or engraved designs of tulips and other floral devices have survived, which were made at these works. In these pieces the 'cutting' and 'flowering' have been done with a wheel or sharp instrument, the strokes of the hand work being distinctly visible, and entirely distinct from the frosting produced by means of acids. The Stiegel glassware was of better quality than any produced elsewhere in the colonies down to the period when its manufacture ceased. A considerable quantity of glass must have been produced, as many identified pieces are to be found in the possession of collectors. Mr. Robert Coleman Hemphill of West Chester, Pennsylvania, possesses a set of the dark blue sugar bowls, which, without their lids, now serve the purpose of finger bowls. These were made for his ancestor, Robert Coleman."' As a modern touch one might say that a Stiegel tumbler sold in New York recently (1913) for \$2I and a Stiegel mug for \$19. A number of letters of Stiegel's to John Dickinson (evidently his creditor, but, as evidently, a kindly one), are among the Logan Papers in the Historical Society of Pennsylvania. The following letter is inserted, to show his pleasure and interest in his newest venture, the Glass Works, and his amazingly care-free outlook, even when telling $\mathrm{Mr}$.

${ }^{1}$ Bulletin of Pennsylvania Museum, January, 1906. 



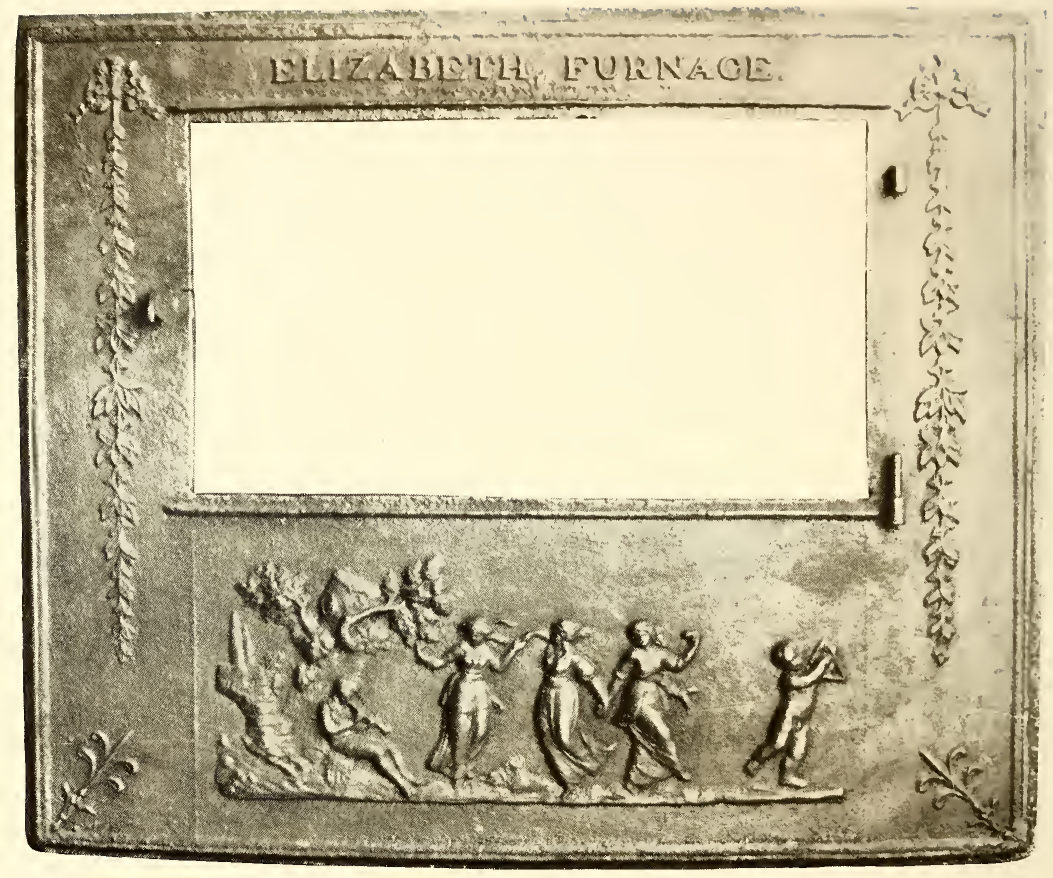

Stove door plate, cast at Elizabeth Furnace. Owned by the Pennsylvania Museum in Memorial Hall. 
Dickinson to sell the iron works, on which the latter probably had a mortgage with Daniel Benezet.

"Sir

\section{"Elizabeth Furnace, June $24^{\text {th }}$ I 77 I}

"Your favour of the Ist instant I Received and am obliged to you, I make no Doubt but you Recomand and Encourage the Manufactory all you can as an undertaking so advantageous to the Good of the province and Country -I now go on with great perfection in that Art-so that Alexandr. Bartram who was here and Viewed the same aknowledged that it was equal with any that ever he saw from Great Brittain and Agreed with me for a large Quantity with a resolution to stop his importation and Take all from me.-Concerning the works they are too High and no body at present times will give near the price for them, if you can sell them, I have no objection, any thing I can serve you In you will freely command-Mrs Stiegel joins me in our best Compliments to you and Spouse and am

"Sir

"Your most Humble Servant "Henry W. Stiegel."

"To John Dickinson Esq." "1

The care-free days were nearly over, however. His reputation as a rich iron-master was a soon pricked bubble. Daniel Benezet held a mortgage for $£_{3}, 000$ on Stiegel's share of Elizabeth Furnace, from 1768 ; and in 1770 his entire Manheim estate was mortgaged to Isaac Cox for $£ 2,500$.

He was active in getting up a Lottery in 1765 for the benefit of the Pennsylvania German Society, and in I773, one seems to have been opened to which his own name was attached, and which was for the benefit of his private undertakings. There is a Broadside in the Historical Society's Collections, running thus :

${ }^{1}$ Logan Papers, Vol. 38 , no. 87 , Historical Society of Pennsylvania. 


\section{"Writ of Levari Facias}

"I/3 part of Elizabeth Furnace seized and taken in Execution of the above writ, being late the property of $\mathrm{H}$. W. Stiegel; to be sold by

Lancaster

$$
\text { "John FERREe }
$$

Sheriff

"August I 3 th, I774"

It is useless to detail the business embarrassments which were now overwhelming him. From his letters one gathers that among his creditors, Daniel Benezet and John Dickinson treated him with great consideration and forbearance. Others were not so forbearing, and in the autumn of $\mathrm{I} 774$ he was arrested for debt, and lodged in jail. He was liberated by special act of Legislature passed December 24, I774. Under the title $W$ arrants to affix the Great Seal we find the following:

"To Edmund Physick, Keeper of the Great Seal of Pennsylvania, 28 April 1775. These are to authorize and require you to affix the Great Seal to . . . . an act for the relief of Henry William Stiegel, a languishing prisoner in the Gaol of Philadelphia County, with respect to the imprisonment of his person.

\section{"JoHN PENN}

"Governor and Commander-in-Chief of the Province of Pennsylvania."1

Just why four months should elapse between passing the Act which promptly liberated the prisoner, and the affixing of the Great Seal, is a question.

Early in 1777 great anxiety was felt in Philadelphia as to the possible approach of the British forces, and on April I4 Mrs. Robert Morris wrote to her mother, Mrs. Thomas White:

1 Manuscript Collections, Pennsylvania Historical Society. 


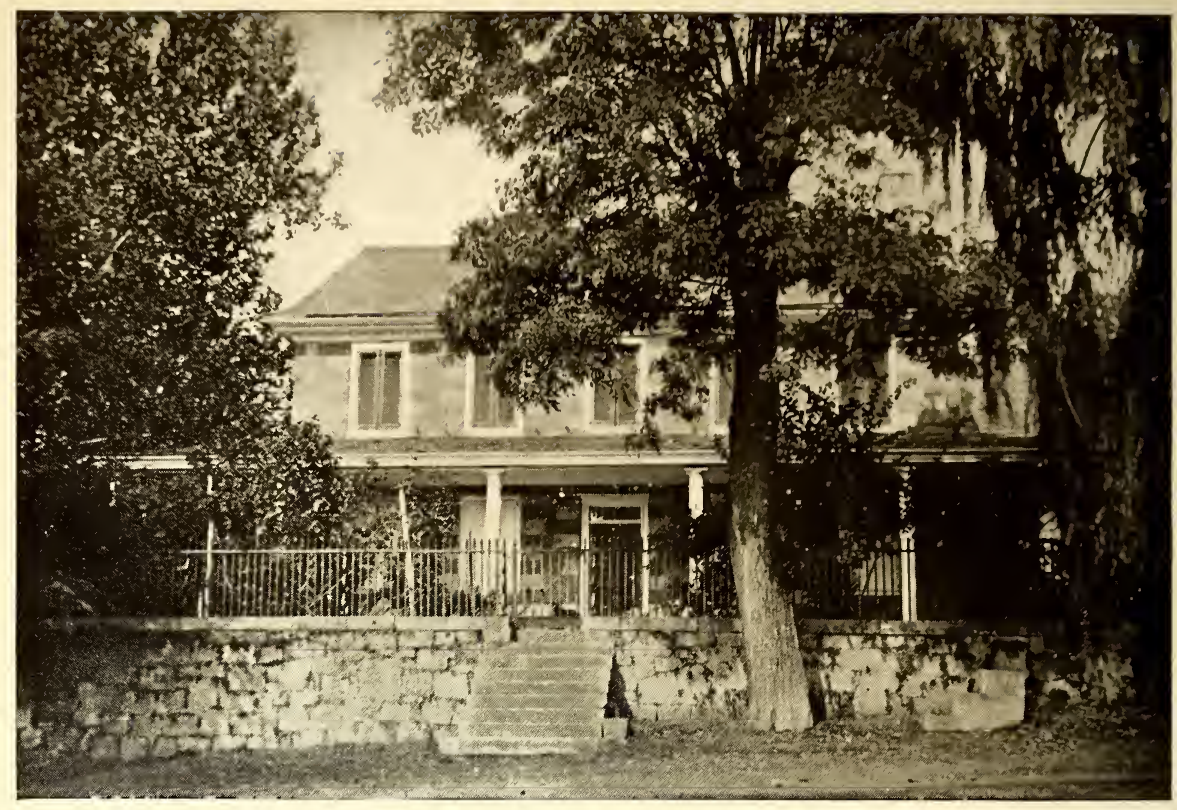

Residence of Robert Coleman, Elizabeth Furnace.

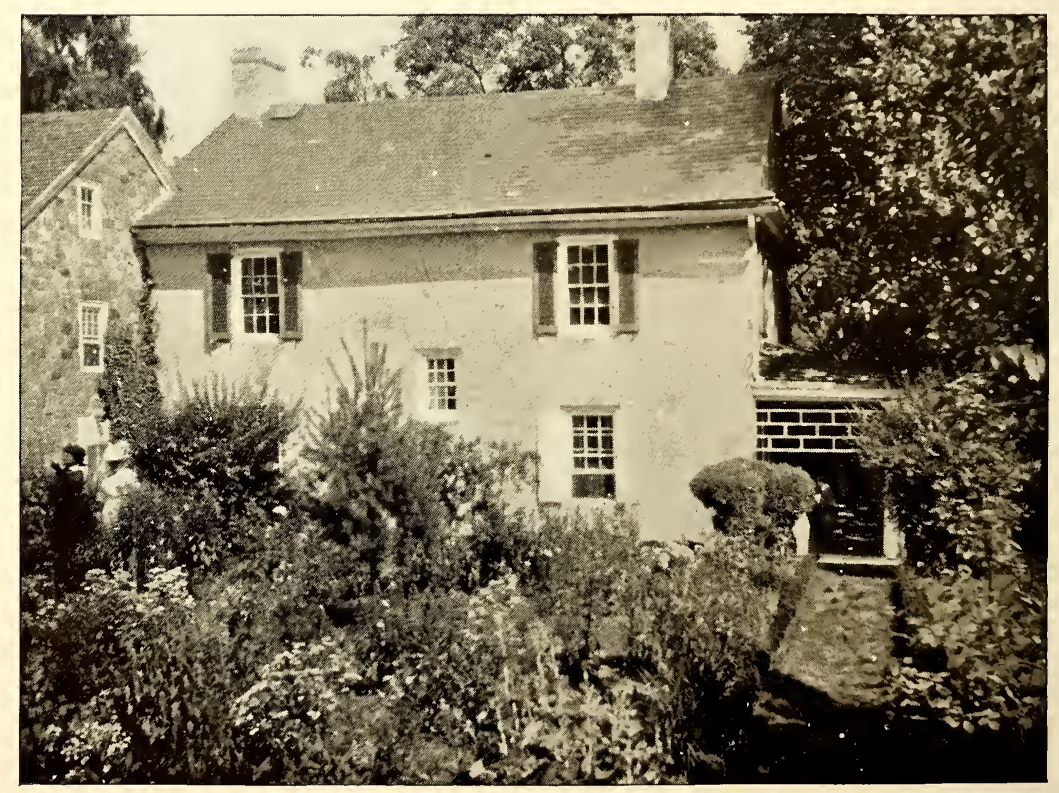

A corner of the Coleman garden, Elizabeth Furnace. 
"We are preparing for another flight, in packing up our furniture and removing them to a new purchase $\mathrm{Mr}$. Morris has made Io miles from Lancaster no other than the famous house that belonged to Stedman and Stiegel at the Iron Works, where you know, I spent six weeks; so am perfectly well acquainted with the goodness of the house and the situation. The reason Mr. Morris made this purchase, he looks upon the other not secure if they come by water. I think myself very lucky in having this asylum it being but eight miles, fine road, from Lancaster, where I expect Mr. Morris will be if he quits this, besides many of my friends and acquaintances. So I will now solicit the pleasure of your company at this once famous place, instead of Mennet, where perhaps we may yet trace some vestages of the late owner's folly and may prove a useful lesson to his successors."1

In a private record, Mr. Robert Coleman, of Lebanon, wrote:

"In the year I776, possessed of but a small capital, and recently married, I took a lease for the Elizabeth Furnace estate for the term of seven years, not anticipating at that time that before the expiration of the lease I should have it in my power to become owner in fee simple of the whole or a greater part of the estate. Success however crowned my endeavors. A new and regular system was adopted, by which the business of ironwork was made to resemble more a well-conducted manufactory than the scenes of confusion and disorder which had before that time prevailed in that business. During the continuance of the lease I made several purchases of lands contiguous to the estate, and in the year I 780 I purchased from John Dickinson, Esq. the one undivided third part of the Elizabeth Furnace and lands thereunto belonging, he having before that time become the owner of all the estate and interest which Alexander Stedman held in the same. In the year I784 I purchased out Mr. Charles Stedman, who also held an undivided third part of the estate. The remaining third part of the original estate was not purchased by me from Daniel

1 Pennsylvania Magazine of History and Biography, I, p. 225. 
Benezet until the year I 794, he either not being inclined to sell or asking more than I thought it expedient to give."1

Having been placed by Robert Coleman at Elizabeth Furnace as foreman, Stiegel wrote to Jasper Yeates of his precarious position, and soon after, large orders were received from the government for shot and shell. In the spring of 1777 the furnace became overtaxed and he suggested to the authorities that more power could be had by conducting the water from Saw Hole around the base of Cannon Hill to Furnace Run. The government sent him about two hundred Hessian prisoners, taken at Trenton, to dig this canal, over a mile in length. Many of the Hessians remained and became good citizens; it is just possible that they may have been induced by the offer of Congress of 29 April, I778, under which " 50 acres of land were granted to any private soldier who deserted from a foreign regiment in British pay. The execution of this project was confided to Benjamin Franklin, who speedily had the eloquence of Congress translated into very plain and intelligible German, and printed inside the covers of parcels of tobacco made up in imitation of those which were sold across the counters of a rural store. Franklin contrived that a number of these packages should fall into the hands of General Von Hiester's foragers, and the event showed that many a Hessian grenadier, as he ruminated over his pipe, had dwelt lovingly on the tempting offer which he found within the wrappers."2 In payment for the work done at the furnace for the government, Hessian prisoners were sent there. In the Pig Iron Book, under date of August I4, the management is credited to twenty-two prisoners, six months, twentyfour and one-half days at eight shillings per week, and four prisoners at forty-five shillings per month.

${ }^{1}$ Iron making in Pennsylvania, by James Swank.

2 The American Revolution, Sir George Otto Trevelyan, III, p. 29. 
Stiegel left Elizabeth finally in I778, and shortly after, his connection with iron making ended. Few and evil, from a worldly point of view, were his last years. His nephew, George Ege, had been the owner of Charming Forge since I774. Stiegel seems to have found work and a home there, as book-keeper. Later, for a while, he tried to support himself and his wife by teaching school. His former workmen did all they could; they cared much for him, and sent their children to be taught. He struggled manfully against poverty and disaster, until the death of his wife; he seems, then, to have gone back to Charming to die. The end came in I 783 , when he was nearly fiftyfour years old.

In I776 Robert Coleman's residence at Elizabeth Furnace began. His patriotism has been spoken of elsewhere. ${ }^{1}$ Of the other aspects of his life there, the verse "Not slothful in business, fervent in spirit" might be quoted as a condensed description. A Sunday School was kept up there for the children on the place: when no clergyman was available, Mr. Coleman read the service. When a visiting clergyman arrived, he had a hearty welcome (a shade less warm perhaps, if he happened to have Tory leanings) and immediately the unbaptized children on the place, whether Mr. Coleman's or those of his workmen, were summoned to be christened. When the reverend visitor left Elizabeth his usually lean pocket book was comfortably filled and he was sent on his way rejoicing.

Robert Coleman had the honor and pleasure of entertaining Washington there, as friend and guest, and at the request of his host, Washington, later, sat for a portrait to Gilbert Stuart, which is now owned by Mr. B. Dawson Coleman. On retiring from business, in I809, $\mathrm{Mr}$. Coleman, with his family, removed to Lancaster, where for

1 See Cornwall Furnace and Salford Forge. 
years his house was a centre for the social life of the time. It was probably a matter of the slightest moment to him, that he was a handsome man, with the Irish beauty of blue eyes, dark lashes and hair, which some of his children inherited. There are many traditions yet told over Lancaster tea cups, of the lovely Coleman sisters, Robert's daughters, two of whom died young. It is said, one cannot say how truly, that the Rev. William A. Muhlenberg later the founder of St. Luke's Hospital, New York, who was engaged to Sarah Coleman, threw into her grave the engagement ring and the rough copy of a hymn he had just written,- "I would not live alway."

In these days, when people are so afraid to take stands, or make public their religious beliefs and practices, it is well to remember that our grandmothers were not. Robert Coleman and his wife, Anne, were very religious and not ashamed of their religion. They were liberal supporters and devoted parishioners of St. James' parish. As there were no bishops of the Episcopal Church until after the Revolution, Anne had never been confirmed. The first time a bishop came to St. James', Lancaster, she said she wished to be confirmed. The bishop suggested a private service for her; but she would have none of it. So at eighty years of age, she, who had been a communicant and leading parishioner for years, came up with all her children to receive the grace of confirmation. ${ }^{1}$ Robert Coleman's active and beneficent life ended on the fourteenth of August I 82 5. He is buried in St. James' Churchyard, Lancaster.

Elizabeth Furnace was in almost continuance operation, until $\mathrm{r} 856$, when it was abandoned. The property is still in the possession of the Coleman family.

\section{Augusta M. Longacre.}

1 Notes furnished by Mrs. Horace Brock, great-granddaughter of Robert Coleman. 



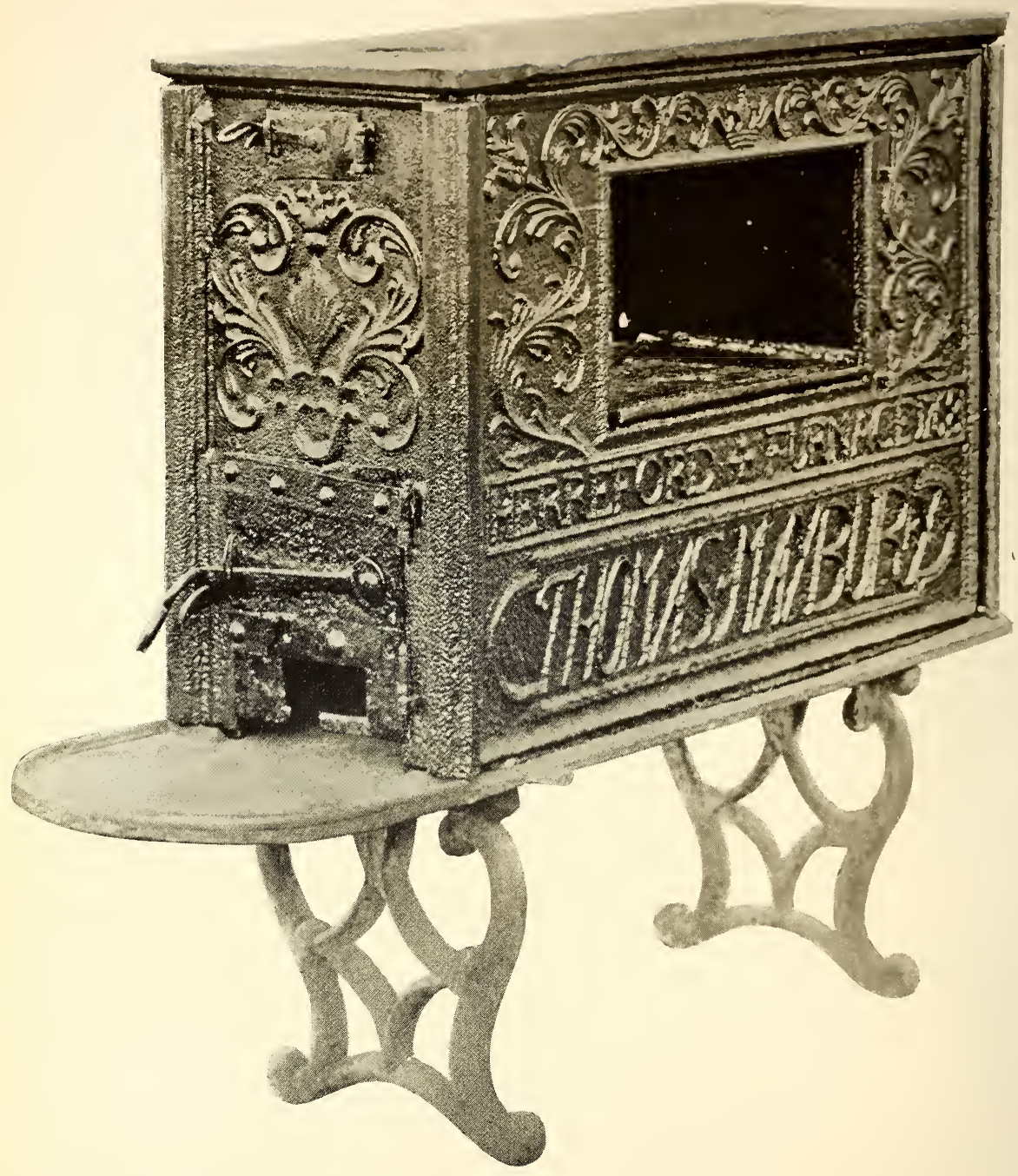

Ten Plate Stove cast at Hereford Furnace, i 768, by Thomas Maybury. Owned by Col. Henry D. Paxson. 
HEREFORD FURNACE.

\section{Berks County.}

For this paper we wish to give full credit to Mr. $\mathrm{H}$. Winslow Fegley, of Reading, from whose article, "Old Charcoal Furnaces in Eastern Berks County," it is taken.

"The first map made of Hereford township is in existence, the property of Horatio K. Schultz. It was made by David Schultz (I7 I7-I797), an able colonist, surveyor, scholar.

Hereford Furnace stood on the west bank of the west branch of Perkiomen Creek. It was in blast in 1753 , and stoves were cast there as late as 1767 . Of Thomas Maybury's early history little is known. ${ }^{1}$ The first settlers of Hereford of whom we have a record are mentioned in Rupp's History as settling here as early as 1732 , being the time when the Schwenkfelders-the pilgrims of the Perkiomen Valley - arrived from Europe. Maybury was a power in the neighborhood and, at one time, a rich man, employing fifty to one hundred men. Some of them were wood choppers, who got from thirty to fifty cents a cord for cutting. Then came the teamsters, who, with either a pair of mules or a yoke of oxen hauled the logs together. Each boasted as to his ability to drive a mule through the cutting over stumps and stones to the coal hearth without upsetting his load. Some of the haulers used a horse and sled, the runners of which were well greased with bacon so as to slide the load over the small stones and brush, to the hearth.

The charcoal burners always travelled in pairs, and as the

1 See Green Lane Forge. 
charring needed constant watching, they were obliged to remain with the burning heap. While one was on active duty for twelve hours his partner was in the hut, sleeping. These huts were made of saplings and the interstices filled with leaves and earth. In such huts they spent many days. Their bill of fare was not elaborate. It consisted generally of-breakfast, flitch and potatoes; dinner, potatoes and flitch, and for supper, meat and potatoes. A stove was exhibited at the World's Fair Chicago, I 893, which was three feet long, one foot wide, box shape, with an oven above. On both sides this inscription is cast: "Hereford Furnace, I767, Thomas Maybury." A placard below said "The Oldest Cooking Stove in America." It is owned by the Michigan Stove Company. Besides stoves, Maybury manufactured everything the earlier settlers needed. In his palmy days, on his trips to Philadelphia, he would get ten dollar bills changed into small coin. On returning to the furnace he would call the children of the workmen together, and, taking one handful of coin after another, throw them broadcast, much as one feeds chickens. In this his delight is said to have almost equalled that of the children. He died poor, after many years of toil. His bones now rest beneath large trees, just such trees as he had cut down for his industries and on the very land where his men burned the charcoal. Although unmarked, generation after generation respects this ground as the Maybury burial plot." 



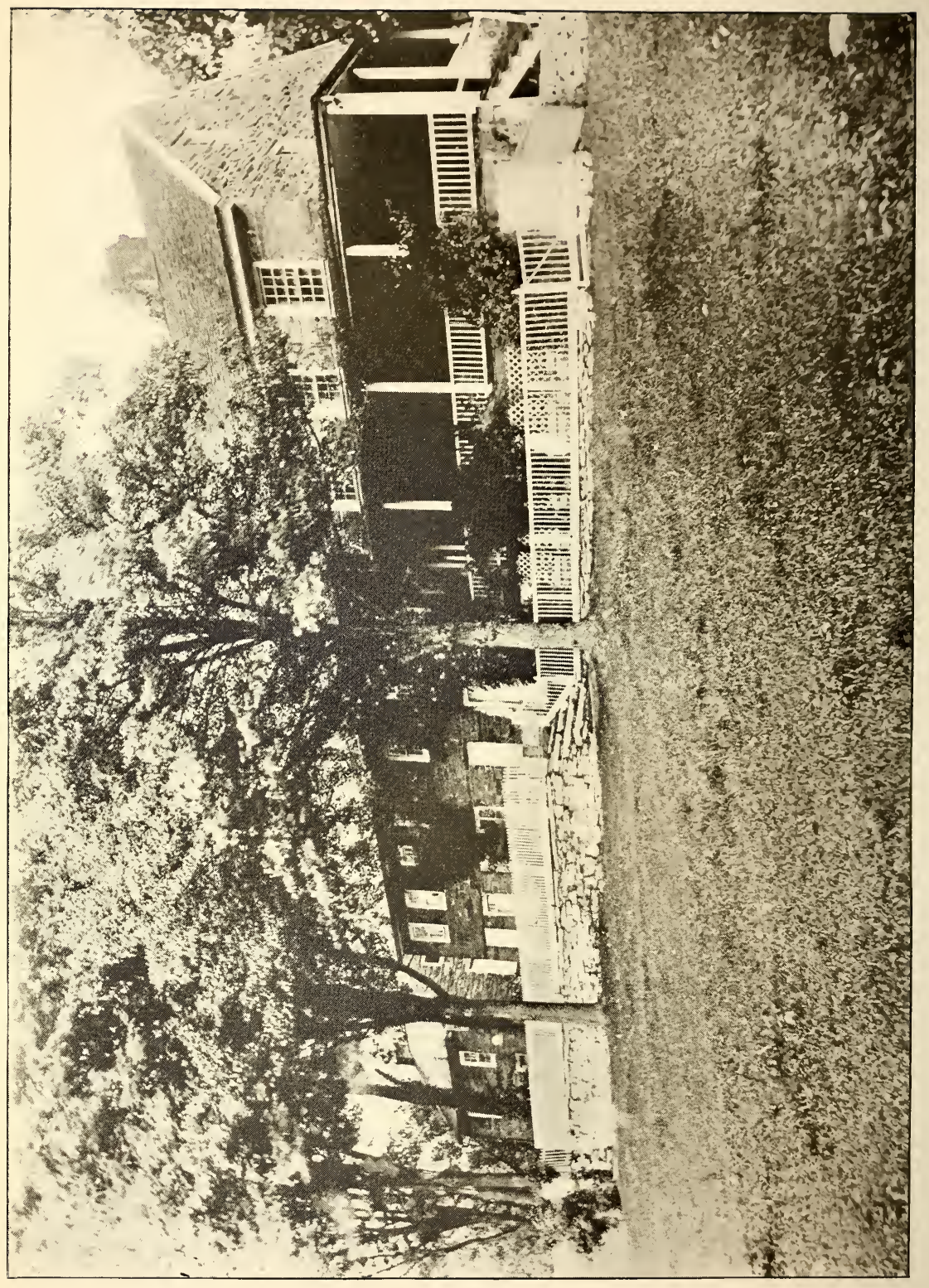

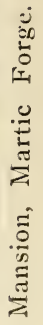




\section{QUITTAPAHILLA FORGE.}

\section{Lancaster County, later Lebanon.}

This forge, called afterwards Newmarket, was built about $175^{\circ}$ on land taken up on a warrant granted to Gerrard Etter, a German, December 16, 1747. It was owned and partially operated by him and his son, until I793, when it was sold to Adam Orth.

Leased by James Old in 1767 , it was operated by him for several years, and is chiefly noted in these days as a place where Robert Coleman learned much of the mystery of iron making, and also where he probably first met Anne Old, who later became his wife.

\section{MARIA FORGE.}

\section{CARBON COUnTY.}

Little is known of this forge beyond the name, and the fact that it was situated on Poco Creek near Weissport. A blast furnace was built later, which was finally abandoned in I861. The owner, Rev. George Michael Weiss or Weitzius, was a native of the Palatinate on the Rhine. Coming to America in I 727, he settled at Skippack, Montgomery county, and seems to have been interested in both iron making and the cure of souls, as he had charge of various Reformed congregations in Pennsylvania and New YYork. He died about I 763, and is buried in the church at New Goshenhoppen. On his tomb are these words :

"Hier ruhet der Ehr

Herr Weiss!"1

${ }^{1}$ Life of Rev. Wm. Smith, p. 89. 


\section{Lancaster County.}

On Furnace Run, a small branch of Pequea Creek which runs into the Susquehanna, near the village of Colemanville, in Lancaster county, may be seen to-day an old cinder heap. Inquisitive minds questioning the placing of the cinders there, will find that this is all that remains of the old furnace with the odd name "Martic."

It was originally called Martock, for a village of that name in Martock hundred, Somerset, England, evidently named by an early settler, with the feeling of the immigrant for the old country. "The name is said to be derived from mart and oak, from the fact of the market having formerly been held under an oak tree in the old English town, the site of which tree is now occupied by an elegant fluted column."

Martic Furnace was built in $\mathrm{I} 75 \mathrm{I}$ and $\mathrm{I} 752$. It was built and run by the brothers, Thomas and William Smith. ${ }^{2}$ In $175^{2}$, Thomas was sheriff of the county and in 1769 he was put in jail for debt. Edward Shippen writes "Tom Smith, the Sheriff, was almost ruined by the office"; those holding such an office to-day seldom have this experience.

In the same year, I769, Martic Furnace and Forge were sold by the sheriff, the advertisement reading thus:

"By virtue of a writ to me directed, will be exposed to sale by public vendue, on the 30 day of January inst., at Io o'clock in the morning at Martic Furnace in Lancaster

1 Lewis's Topographical Dictionary of England. later.

2 History of Lancaster County, by Ellis and Evans. See Chain of Title 



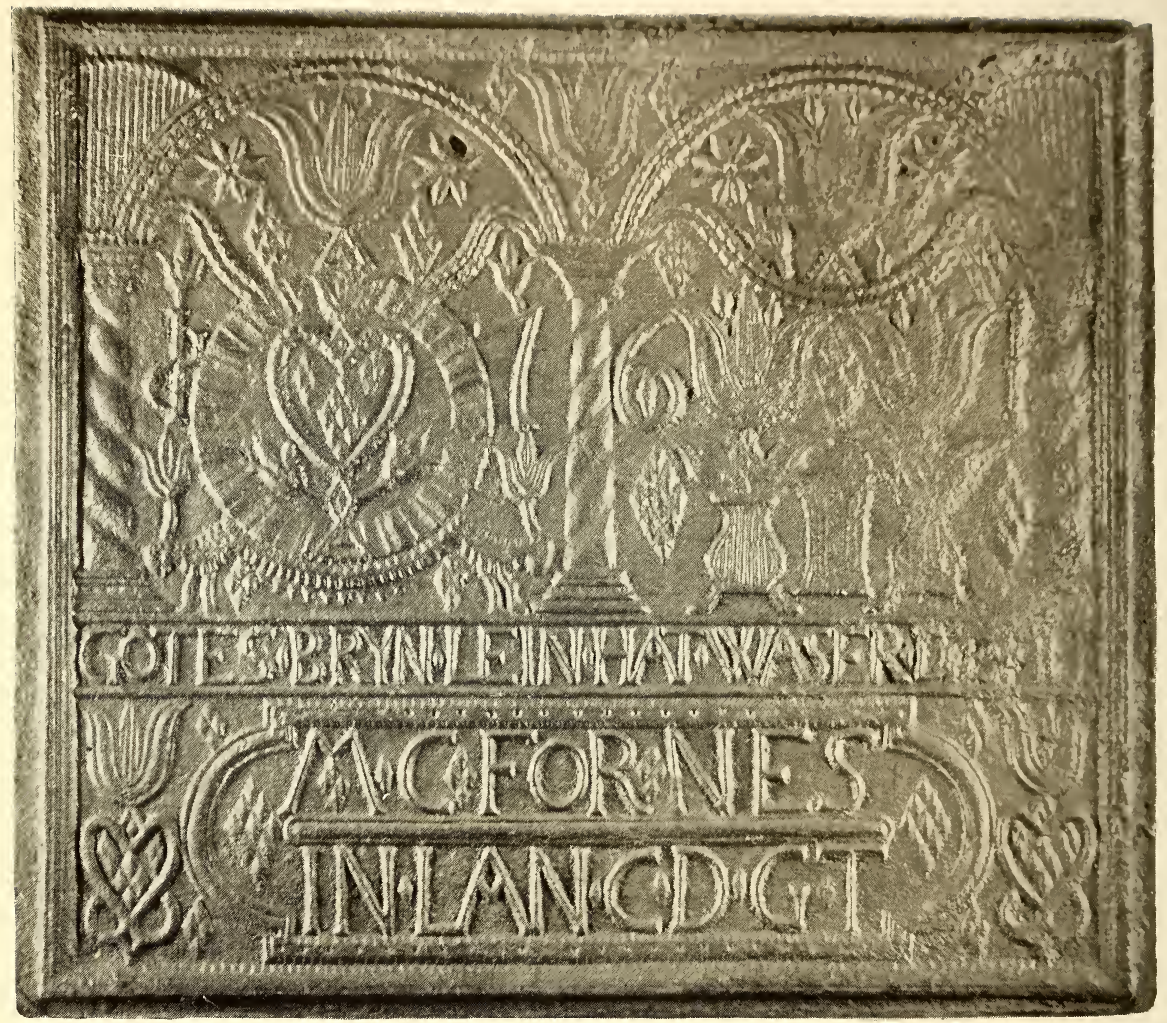

Stoveplate, Martic Furnace. Owned by Mrs. A. J. Steinman, Lancaster. 
County, the said furnace and forge, together with upwards of 3,400 acres of land thereunto belonging. The improvements at both furnace and forge are very good, viz.: At the furnace, a good dwelling house, stores, and compting house, a large coal house, with eight dwelling houses for labourers, a good gristmill, Smith's and Carpenter's shops, 6 good log stables, with 4 bays for hay, a number of pot patterns, and some flasks for ditto; stove moulds, \&c., \&c., a good mine bank abounding with plenty of ore, so convenient that one team can haul three loads a day; about I 5 acres of good watered meadow, and as much adjoining may be made: The Forge is about 4 miles distant, now in good order, with four fires, two hammers, and very good wooden bellows, a dwelling-house, store and compting house, with six dwelling houses for the labourers, two very good coal houses, large enough to contain six months' stock, three stables, Smith's and Carpenter's shops, two acres of meadow made and about 1,500 cords of wood, but in the woods at both places; there is plenty of water at said works in the driest season, and they are situated in a plentiful part of the country, where they can be supplied with necessaries on the lowest terms: And to be sold the same day, a very good plantation, containing 200 acres of patent land, clear of quit-rent, adjoining the lands of Benjamin Ashleman, the Widow Haiman, and others, in Conestoga township. Also two slaves, one a Mullatoe man, a good forge man, and the other a Negro man, and three teams of horses with waggons and gears \&c. All late the property of Thomas Smith, James Wallace, and James Fulton : seized and taken in execution, and to be sold by

James Webb, Sheriff."

A glimpse of the tragic and historic side of Martic is given in the following story related by Ellis and Evans in their History of Lancaster County.

"In and about Lancaster County, there was a group of men banded together to drive out the Indians, and under Capt. Lazerus Stewart, these men, who were called the 
Paxton Boys, in Dec. 1763 , started toward Conestoga, an Indian town, purposing to destroy it and its people. They did murder six Indians and burned their buildings. One boy made his escape and gave the alarm at the place of Capt. Thos. McKee, manager of the 'Indian Farm.' The same day, Bill Sock, an Indian famous in those parts, having committed numerous murders and much feared and hated by his neighbors, went with several other Indians to sell baskets and brooms at the Iron Works of Thomas Smith, (Martic Furnace.) When Sock and those who accompanied him did not return, other Indians who lived near Harrisburg Turnpike became much alarmed and decided to go to Lancaster-here they were put in the work-house for safety-The work-house was attached to the jail. The Paxton Boys had murdered the others and Herr, who resided in the Manor House, brought news of the dreadful massacre. On Dec. 27, 1763, Sheriff Hay wrote Gov. John Penn that fifty or sixty Indians had been killed by the Paxton Boys. This band of men became so vicious and so vindictive that the Indians were afraid to hunt and finally were driven out altogether, and the ironworkers at Martic saw no more of the red men."

The furnace went out of blast during the Revolution, although it was in existence as late as 1793 .

The forge in connection with Martic Furnace was started in $1755^{\circ}$ In 1760 , the whole property was sold to William and Samuel Webb and Ferguson McIllvaine. The latter became manager.

Many times did the property change hands between I 760 and 1883 , when it was last in operation.

Robert S. Potts, who died in 1886 , the last owner of the Forge, wrote:

"There used to be a small rolling mill near the Forge that stopped running some fifty years ago. There was also a charcoal furnace called Martic Six miles east of the ${ }^{1}$ Swank, Progressive Pennsylvania, p. 187. 



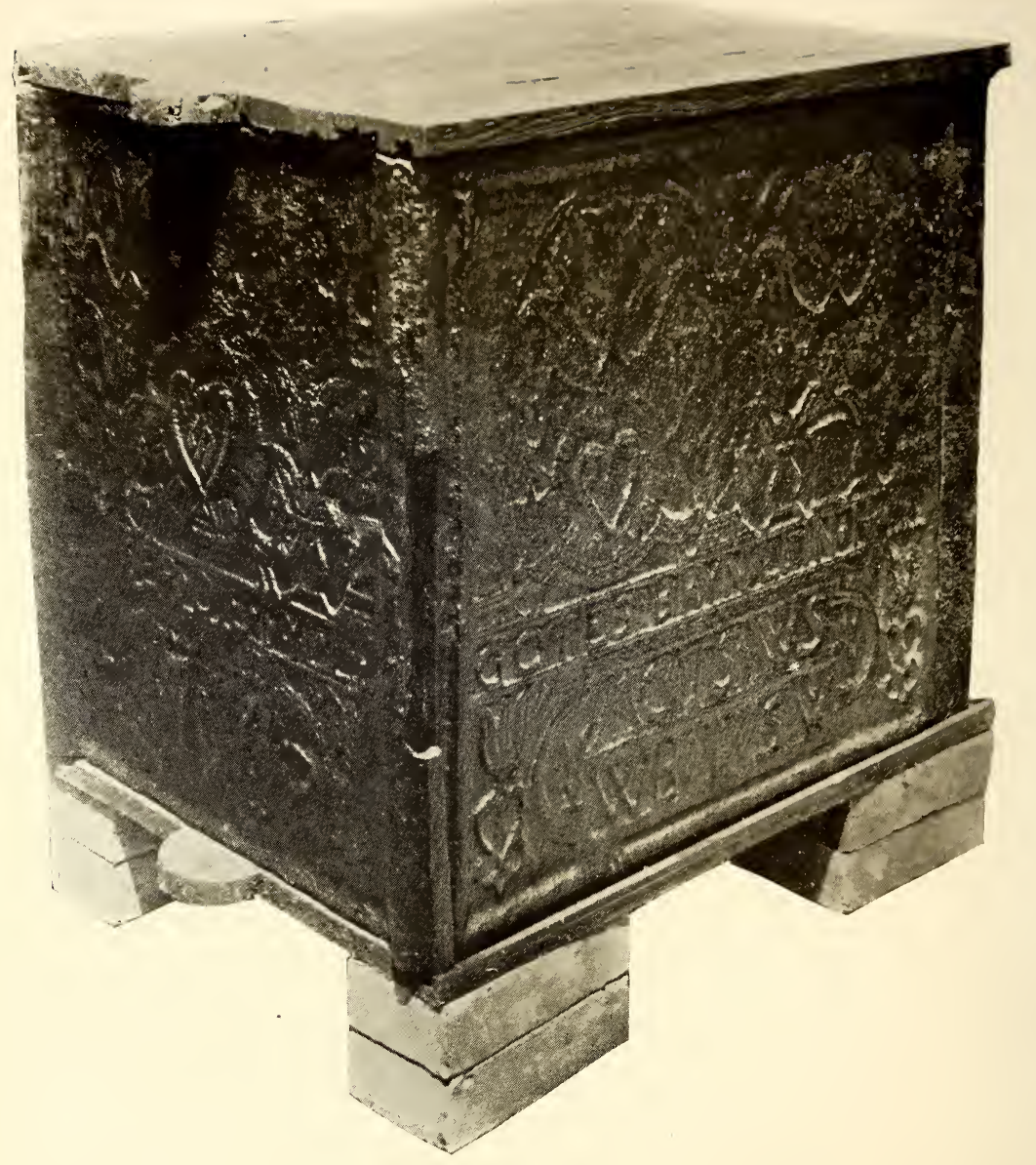

Complete Fiveplate Stove, i760. Martic Furnace. Owned by Col. Henry D. Paxson. 
Forge, but I have been unable to ascertain its history beyond the fact that it was owned and operated by the Martic Forge Company; when that was, however, or how long it was in blast, I can not learn. The old cinder bank is still visible. During the Revolution round iron was drawn under the hammer at the forge and bored out for musket barrels at a boring mill, in a private road, doubtless with a view to prevent discovery by the enemy."

One thing more told by Robert S. Potts is that negro slaves were employed at Martic from the very beginning, and it is interesting to know that until it ceased operation in 1883 , negroes continued to be the chief workmen. A long row of stone houses was occupied by these men.

Through the interest and courtesy of Col. Henry D. Paxson we are able to give a complete Chain of Title of Martic Forge.

Chain of Title of Martic Forge. I769.

6th Sept'r James Webb, Esq., Sheriff, sold Furnace and Forge and 3404 acres of land in Martic Township to Ferguson Mcllvaine, as the property of Thos. Smith \& Co.

I 2th Sept'r Ferguson McIlvaine sold Furnace and Forge to Adam Hoopes.

I 770.

2nd June. Adam Hoopes and wife conveyed Furnace and Forge to John Malcolm, George Munroe, Samuel Patterson and John McCalmont, to each one-fourth.

I 77 I.

$25^{\text {th }}$ May. John Malcolm and others sold the one-eighth part of Martic Forge and I 275 acres of land to Joseph Musgrave.

I 772

22nd June. John Malcolm and others sold the one-fourth part of Martic Forge, \&c., to John Fox and 
Daniel Longstreth, in trust, for William Juto, Robert Harris, James Haldane, William Hazlewood, Nicholas Barnard, Stacy Nepham, Peter Sutter, James Fulton, Alexander Graham, John Kidd, Peter Young, Anthony Yeldale, James Bernwick, James Longhead, John Clark, Zachariah Nieman, Robert Graves and the said John Fox and Daniel Longstreth, William Hazlewood, Peter Sutter and Alexander Graham each to have onethirty-five part, the rest to have two-thirty-five parts each.

I 774 .

I 8th Feb'y John Malcolm and others sold one-fourth part of Martic Forge, \&c., to William Montgomery and Matthew Wilkin-to each a moiety of the fourth part.

do. John Malcolm and others sold one-eighth part of Martic Forge, \&c., to Michael Hillegas.

1775 .

23d Feb'y. John Malcolm and others sold one-eighth part of Martic Forge, \&c., to John Welsh.

I777.

28th Sept'r Matthew Wilkin sold a moiety of one fourth part of Martic Forge, \&c., to William Montgomery, who then held one-fourth part of the Forge, \&c.

8th Dec'r. William Montgomery sold his one-fourth part of the Forge and lands to Michael Hillegas.

I 788.

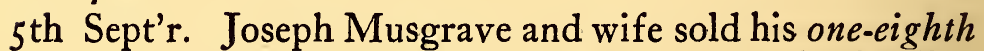
part of Martic Forge, \&c., to Michael Hillegas.

In the preceding conveyances to Michael Hillegas, the one undivided fourth part of Martic equal to six-twenty-fourths, purchased from William Montgomery; the one-eighth part, equal to three-twenty-fourths, purchased from 



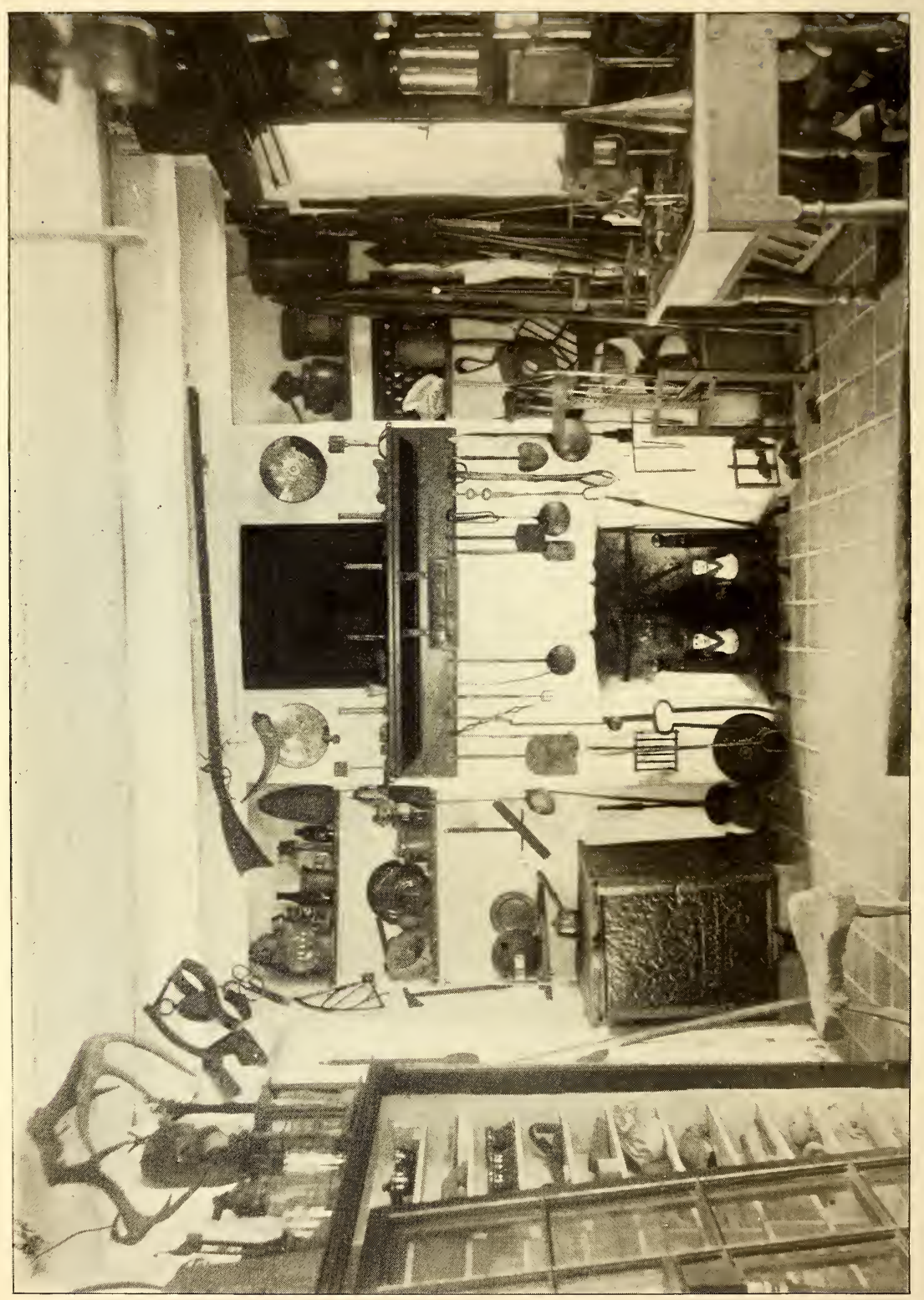

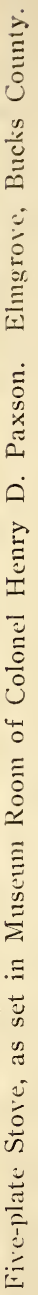


Joseph Musgrave: and the one-fourth part, equal to six-twenty-fourths, purchased from James Fulton and others, amounting in the whole to fifteen-twenty-fourth parts, were purchased by the said Michael Hillegas in partnership with Matthias Slough and George Ege, tho' the Deeds were in the name of M. Hillegas alone. These are only conveyances for twenty-one thirty-five parts of the fourth purchased from James Fulton and others-the remaining fourteen-thirty-five parts being claimed or released.

1783 .

26th June. Geo. Ege conveyed his interest, amounting to five-twenty-fourth parts, to Matthias Slough, who then held ten twenty-fourth-parts.

I792.

27th Sept'r. Michael Hillegas conveyed to Richard Footman and others, surviving assignees of Matthias Slough, then a Bankrupt, the interest which Matthias Slough owned in the works and the title to which was in his own name, as well as Mr. Ege's share, which had previously been sold by him to Slough, amounting in the whole to ten twenty-fourth parts of the Forge, \&c.

I793.

I Ith March. Richard Footman and others, surviving assignees of Matthias Slough, sold his share in the estate (viz: ten-twenty-fourth parts thereof to Geo. Ege).

I3th March. Michael Hillegas sold to Robert Coleman and George Ege the one-eighth part, equal to three-twenty-fourths, purchased from John Malcolm and others, and his third part of fifteen twenty-fourths, equal to five twentyfourths, which he held in partnership with Matthias Slough and Geo. Ege, the whole amounting to eight-twenty-fourth-parts. 
I793.

3oth Sept. John Miller, Sheriff, sold the one-eighth part of Martic Forge and land, to Robert Coleman and Geo. Ege, late the property of John Welsh.

1803 .

8th July. Geo. Ege sold to Robt. Coleman his one-half of all the Martic Lands purchased and held by Robt. Coleman and Geo. Ege in Company or granted and conveyed to them in Fee as tenants in common-purchase money £2500.

Same day. Geo. Ege sold to Robt. Coleman all the share and interest in the Martic property which formerly belonged to Matthias Slough and which he purchased from his assignees-consideration $£ 4000$.

I 804 .

3oth Jany. Robt. Coleman his one undivided half part of Forge and lands to Edward Brien for $£ 6500$.

One does not easily fathom the motives and intentions of those who preceded us in Pennsylvania by a century or so, but to a casual reader of the names of purchasers of Martic on June 22, I772, in the foregoing Chain of Title, it seems as if taking a "share" in an iron property had been a rather popular kind of speculation. Reading further on, we find a name, known to students of American History, but not so familiar as it should be in our own state. Michael Hillegas was a Philadelphian who, distinguished early for his personal gifts, his success as a merchant, and his philanthropy, became later the first Continental Treasurer (in I775). In 1777 he was appointed the first Treasurer of the United States, ${ }^{1}$ and continued in that responsible office until 1789 .

Mabel Rogers Baird.

${ }^{1}$ Journals of Congress, III, 3 or. 


\section{POTTSGROVE FORGE.}

Philadelphia County, now Montgomery.

This ancient forge takes its name from the Potts family, whose annals might almost be said to cover the history of the iron industry in eastern Pennsylvania. The name is connected with the first furnace erected by the earliest settlers under William Penn, and in continuous line they followed the manufacture of iron, until the annual output of their industries was reckoned in the millions.

The German colonists, under their leader Pastorius, must be credited with the enterprise which first opened up the rich iron deposits of eastern Pennsylvania. Letters of William Penn, written to James Logan early in I700, refer often to the iron mines in the Schuylkill region, and express a great desire to have them opened, but it was not until I 7 I 6 or I7 I 7 that Thomas Rutter, a man of much ability, who had succeeded Pastorius as chief magistrate, left the German settlement and went to the banks of the Manatawny, a stream which joins the Schuylkill about thirtyfive miles above Philadelphia.

In the Germantown colony was a family by the name of Potts recently come from Wales. Their little son, Thomas, though born across the ocean, was brought up among these Germans who had transplanted a bit of the fatherland to this country. Their language was to him like his native tongue, and his marriage at the age of nineteen to Martha Keurlis (Kerlin), a member of one of the twelve families who came with Pastorius to America, allied him still closer to their interests. He was educated as a Quaker and from the record of his marriage it would 
appear that both he and his bride were members of meeting. We know that his uncle, Thomas Potts, senior, was an active Friend, and that Peter Keurlis was nominally one, and that the young people conformed to Friends' custom. They passed, as it is called, two meetings, and at a monthly meeting at Abington, third month, I699, were formally joined "in the unity of Friends."

After he married, young Thomas held several posts of honor in the settlement. The German tongue was universally used, and yet the presence of English Quakers made it important to have officials who could speak both languages. He was influential with both parties, and lived happily in or near Germantown, until the death of his wife, which took place about I7I6. It was probably while his family was broken up by this affliction that he was induced by Thomas Rutter to emigrate to the Manatawny. Here he purchased lands-married a second time (Magdelen Robeson) about I7 I8, -and, after the death of Rutter, became the principal owner and manager of the iron works on the Manatawny.

History gives us only the merest glimpses of the existence of this early forge; the "Potts Memorial" says: "A large tract of land was owned by the family, and it is believed that here they had early a forge or furnace, some remains of which a local antiquary said he had seen near the river." Andrew Robeson, whose sister was the second wife of Thomas Potts, wills to his son in 1719, "that Foundement and the house where John Owen lives"- - the word foundement being an obsolete word for foundry. It was rebuilt in $175^{2}$, by John Potts the great proprietor (son of Thomas Potts, Junior). Confirmation of this is to be found in the following entry in the old Day Book of the Potts Iron Works. ${ }^{1}$

1 Now in possession of Ex-Governor Pennypacker. 
"March I759-Credit Henry Read hauling one day with his team at the new Forge-Ios."

And that it was in use contemporaneously with the larger enterprises of the Valley, Warwick and Pine forges, is shown by this record,

"April 3rd 7758.

Credit Martin Glass for sundry work

$861 / 2$ days at Pottsgrove

$2 \mathrm{r} 1 / 2$ " "Warwick

I I $7 \frac{1 / 2}{2}$ " " the Valley

Making four Racks

a garden at Pine"

Another entry-Jan. I 758

"Smith Shop Dr. to Bar Iron

made and drawn at Pottsgrove

L S d"

I $\quad 2$

"Jan. 1758

"Sundry accounts Dr. to Michael Paul

Mt Joy Forge for hauling I 8 tons Pigg Iron

Pottsgrove Forge for hauling 2 tons Pigg Iron-"

The old forge did not fade from memory, even when its usefulness was passed - for it gave its name to the district at the confluence of the Schuylkill and the Manatawny, and the town laid out there by John Potts in $175^{2}$ was called Pottsgrove. ${ }^{1}$ This town was laid out after the manner of Germantown in one long street a hundred feet wide, called after the English custom, High Street. The lots were sixty feet in front, extending back three hundred feet. At the end nearest the river was the mansion of the founder, looking down upon the town. The houses

1 Afterwards changed to Pottstown. 
erected by himself and his sons were large stone buildings, intended to serve many generations. John Potts' son Thomas, at his father's request, occupied the mansion, and was living there in I774. No doubt during the years of the Revolution Washington was often his guest, and it was here perhaps that the great Commander formed the plan to winter his army at Valley Forge on the property of Thomas's brothers and cousins who seem to have willingly relinguished their houses to accommodate the general and his officers. ${ }^{1}$

A granite tablet has been recently erected by the Montgomery County Historical Society (1913) to commemorate the Continental Army's stay at Camp Pottsgrove in 1777. The tablet erected reads thus:

"Camp Pottsgrove. General Washington's Continental Army occupied this and adjoining farms September 18 to 26, I777. The outposts were at Washington Hill, Pottstown, Jackson Hill, near Sanatoga ; Swamp-door, east of Fagleysville. Washington's headquarters with Colonel Frederick Antes and Samuel Bertolet, Frederick, Pa. Erected by the Historical Society of Montgomery County, Pa."

Mary E. Mumford.

1 Mrs. James' Memorial. 


\section{OFFLEY'S ANCHOR FORGE.}

\section{Philadelphia.}

In the middle of the eighteenth century there appear to have been three "iron works" in the city proper of Philadelphia. Two of these were the steel furnaces of Paschal and Branson. The third was an important and conspicuous feature of the iron industry of the town, and was known far and wide as the "Anchor Forge" of Daniel Offley, who manufactured anchors for a thriving maritime trade, and who was succeeded by his son, the famous Quaker preacher of the same name.

Daniel Offley (I724-I789) established this business on the Front Street bank of the Delaware River, opposite Union Street, about I750-55. His father, Caleb Offley, of Duck Creek, Newcastle County, was the son of Michael Offley, who in I687 took patent of the Duke of York to a tract of land in the Lower Counties, which he called "High Offley." Except for two years, I 848-50, this estate has remained in the possession of the family, the present owner being John S. Stockley, Esq., whose mother was Margaret Offley. ${ }^{1}$

Daniel Offley, Jr., the noted Quaker preacher, was probably early trained in his father's business, the making of anchors, many being made by them for the use of the government. Daniel, Jr., and his brother Caleb signed the "Remonstrance" to the Governor's Council presented

1 See Family Chart of Michael Offley, in Mss. at the Historical Society of Pennsylvania. This chart was prepared by Mr. Richard P. Tatum, to whose courtesy the writer is indebted for the genealogical material here used. 
by the Friends, September 6, I777, against depriving certain of their fellow-citizens of their liberty, and sending them unheard into exile. ${ }^{1}$ On July 4, I 789, Daniel Offley, Jr., Caleb Offley and Henry Shaw were imprisoned by Captain John McCalla for a refusal to pay the militia tax. Caleb was discharged a few days later, but Daniel remained in prison for over a month, when Captain McCalla, on August 9, went to the prison between eight and nine at night and discharged him without demanding either fee or fine.

The personal appearance of the Quaker ironmaster must have been striking. Several traditions unite in describing him as a handsome, powerfully built, blond man, with regular features and muscular body, strong and broadshouldered, five feet ten inches in height. His voice was noted for its quality and power. It rose above all the din when the iron rang upon the anvil; and when speaking under deep emotion, the rich melodious tones in which his sermons were delivered lent great impressiveness to his message.

Speaking of the forge, John F. Watson remembered "looking through the Front Street low windows down into the smoking cavern below, fronting on Penn Street, where, through the thick sulphurous smoke, aided by the glare of light from the forge, might be seen Daniel Offley, directing the strokes of a dozen hammer-men, striking with sledges on a welding heat produced on an immense unfinished anchor, swinging from the forge to the anvil by a ponderous crane, he at the same time keeping his piercing iron voice above the din of the iron sound."2 Watson

1 Gilpin's Exiles in Virginia.

2 John Fanning Watson, Annals of Philadelphia and Pennsylvania, I, p. 430. 
quotes, with no clue to the author, the following lines written upon Offley at his forge:

"The high sun sees not on the earth such fiery, fearful show;

The roof-ribs swarth, the candent hearth, the ruddy, lurid row Of smiths that stand, an ardent band, like men before the foe,

As, quivering through his fleece of flame, the sailing monster, slow Sinks on the anvil;-all about, the faces fiery glow;

'Hurrah!' they shout, 'leap out, leap out!' bang, bang, the sledges go! A hailing fount of fire is struck at every squashing blow,

While Offley sternly cries, 'Strike! Strike! while yet our heats do glow.'"

Daniel Offley was a well-known minister among the Friends. In 1783 , in company with George Dillwyn, he traveled through New England, and through the neighboring states of Virginia, New York and New Jersey, with the endorsement of his own meeting. In November, I 786, he went with Samuel Emlen to the Barbadoes, where they found all the five Quaker meeting houses destroyed by a recent hurricane, but were aided in their attempt to hold public meetings by the kind attentions of the governor. The ship they made the voyage in was the Cyrus of White Haven. Before returning, Daniel Offley included in his ministerial visits Antigua, Tortola and Santa Cruz.

The yellow fever appeared in Philadelphia in August I 793, and by the end of that month its spread had become so rapid and so fatal, that most of the well-to-do citizens left for the country. Certain persons, however, volunteered to assist the guardians of the poor, whose hands were too full to care for all the destitute. Daniel Offley was not at first one of these, but at the end of a few days he joined the faithful band. Very soon he devoted every moment of his time to attendance on the sick and the dying. On September I7, he called on Miss Sarah Rodman, of Newport, Rhode Island, who was near her end, and on the twenty-fifth he comforted her sister, Hannah 
Fisher, with the remark, "She is the Lord's: let Him take her." He watched her breathe her last next day, and assisted at the interment which followed a few hours later.

There are horrors of that period in Philadelphia yet unwritten, when so many died quite unattended. Wives fled from husbands on their deathbeds, and husbands abandoned wives; parents left their dying children, and children neglected aged parents in distress. The courage of those who remained in the plague-smitten city may be imagined, when the bells were finally forbidden to toll their ceaseless lament, and great composure was needed merely to walk down the street, where the sick-cart and the hearse were met at every hand. Daniel Offley joined Doctor Wistar, and these two were together faithful attendants on the victims, until the doctor was smitten; he recovered, and survived for many years. Fatigued by six weeks of strenuous labor, under such awful circumstances, Daniel Offley finally fell ill on the third of October, and lay, patiently awaiting his expected end. On the seventh he told his distressed wife that he was comfortable in mind and ready to go, and on the eleventh, he died at the early age of thirty-six.

$\mathrm{He}$ is said to have made a prophesy regarding the scourge of which he died, in a letter to Dr. Peter Yarnall at Concord, Pennsylvania, dated 8mo. 7, I $78 \mathrm{I}$. He wrote: "Oh, Philadelphia! Had the many powerful visitations which have been extended to thee been reached forth to Sodom and Gomorrah, they would have repented long ago in dust and ashes. . . . It would be no marvel at all to me if the Lord's anger should rise yet higher, and he should pour out the vials of his wrath upon the inhabitants of this once favoured city!"1 Margaret Morris, the widowed daughter of Dr. Richard Hill, wrote

1 Biographical Sketches and Anecdotes of Friends, pp. 136-137. 
to her son, Richard Hill Morris, from Philadelphia, under date "twelfth of tenth month, I793," herself stripped of her children by the plague, "Last night D. Offley was carried to the silent grave."

Amelia Mott Gummere.

\section{PETER DICKS' BLOOMARY FORGE.}

\section{YORK COUNTY.}

In starting this forge, about 1755 , on a branch of Codorus Creek, Peter Dicks, ${ }^{1}$ of Chester County, opened ore mines along the Southeast slope of the Pigeon Hills near Hanover. No information seems attainable as to this enterprise, except that Spring Forge, III, is said to have taken the place of it, a few years later.

1 Prowell, History of York County. 

FURNACE.

\section{Berks County.}

William Bird, an Englishman, built this furnace in Heidelberg township just south of Wernersville. Most authorities give 1760 as the date, but an entry in a ledger of the New Pine Forges, ${ }^{1}$ which were also his enterprises gives: "Oct. 1756. New Pine Forges to Roxkburry Furnace $D^{r}$.," which makes 1755 a reasonable inference. For a few years Wm. Bird was sole owner here; he died however, in $176 \mathrm{I}$, in middle life, like many other early ironmasters. They worked hard in those days, and lived well, they hunted, and, at times, drank deep; need this have shortened their lives?

Sometime in the next year John Patton married the widow of Mr. Bird, and from that time seems to have been more or less in authority, although from 1764 George Ege is said to have carried the furnace on, under a lease with Mrs. Bird-Patton, until he purchased the property in 1790. There are ledgers and journals of Berkshire Furnace in the collections of the Historical Society of Pennsylvania, from which we give some extracts.

" 1767 . Nov. 9. Spring Forge, Dr. Io Beef cattle $£_{33}-0-0$.

Mark Bird I I ditto, $£ 33-1$ 5-O

I769. John Old, to pigg mettal

Great Spring $D^{r}$. to $P$. Herlinger

Spring Forge, $\mathrm{D}^{\mathrm{r}}$. to castings

1 Manuscript Collections, Historical Society of Pennsylvania. 
1774. Anthony Rush, work and wages for I 5 months \& $20^{1 / 2}$ days in the Mine Hole $£ 43-6-3$

"April I774, John Lesher D . to Pigg Mettle Charming Forge $D^{r}$. to Pigg Mettle pr. the Forge Team Mark Bird Esq. Dr. to Pigg Mettle for 3 tons Piggs for John Old, pr. Furnace Teams sent to the care of Mr. Fricker in Reading. May I 774, Curtis Grubb $\mathrm{D}^{\mathrm{r}}$. to forge castings sent to Womelsdorf."

There is evidently a close connection with a "Spring" work of some kind. The "Spring Book" is constantly alluded to, also a mention of harvest at Great Spring.

"To sundrie in old Spring Book

1776. Sept. Geo. Ege $D^{r}$. to Pigg Iron delivered this month, I 6 tons-£II2.

I776. Aug. Owen Biddle, $D^{r}$. for acct. Committee of Safety To Cannon Shot, I 8 p'd'rs, I $2 d^{\circ} .32$ d $^{\circ} .24 d^{\circ}$. $6 \mathrm{~d}^{\circ} .4 \mathrm{~d}^{\circ}$.

1777. March 31. To Cannon Shot-sent by Conrad Wanamaker to Reading."

In 1783 George Ege rendered an account to the "United States" for shot and shell furnished the government, November I4, I 780, to the value of $£ 2894-$ I I-6.

John Patton in a letter to the Board of War dated "Berkshire Furnace, I 2 Aug. I 780," speaks of it conclusively as "my Furnace." It is said that Ege removed "Berkshire" to Robesonia, towards $\mathrm{I} 800$. Just when the change of name occurred it is difficult to determine. In the Ledgers of New Pine Forges, "Roxkburry" Furnace is mentioned from I 756 to $I 763$, possibly later. The ledgers and journals of Berkshire Furnace run from I 767 on. 


\section{Berks County.}

The early pre-Revolutionary history of the furnace is somewhat shrouded in obscurity. Tradition gives the date of 759 for the building of the furnace and the iron master's house. Mr. Swank, in his "Ironmaking," says: "Hopewell Furnace was built in I 759 by William Bird." A forge was evidently in operation before the furnace and we have interesting proof of the early date of the same, as it is spoken of in the article in this volume entitled New Pine Forges. In this old record we have account of iron delivered to Mr. William Bird at Hopewell Forge, from Warwick Furnace, a near neighbor, in 1744 . In 1772 , after the death of Wm. Bird, when his son Mark had acquired the property, we have evidence of a prosperous iron business by the stoves, cast with much-detailed designs, and marked with Mark Bird's name. The Revolutionary spirit is shown in a motto on one of these which reads " $\mathrm{Be}$ Liberty Thine."1

On Scull's map of 1759 , we find the old road running from Lancaster through what is now Morgantown, and then down the French Creek Valley to Valley Forge. The first twenty miles from Lancaster, it is marked "to Windsor Forge."

After this is passed it is marked "to Reading Forge." This was evidently the old highway between the French Creek Iron Works, both to Lancaster and to Philadelphia. Hopewell is four miles from this road, and the stoves made there were transported by wagon from the furnace, not set up, but in their separate parts, through the neighborhood, and to Philadelphia. The road is now called the Ridge Road, before reaching Morgantown, where the old Cones-

${ }^{1}$ See Sequence of Franklin Fireplaces. 


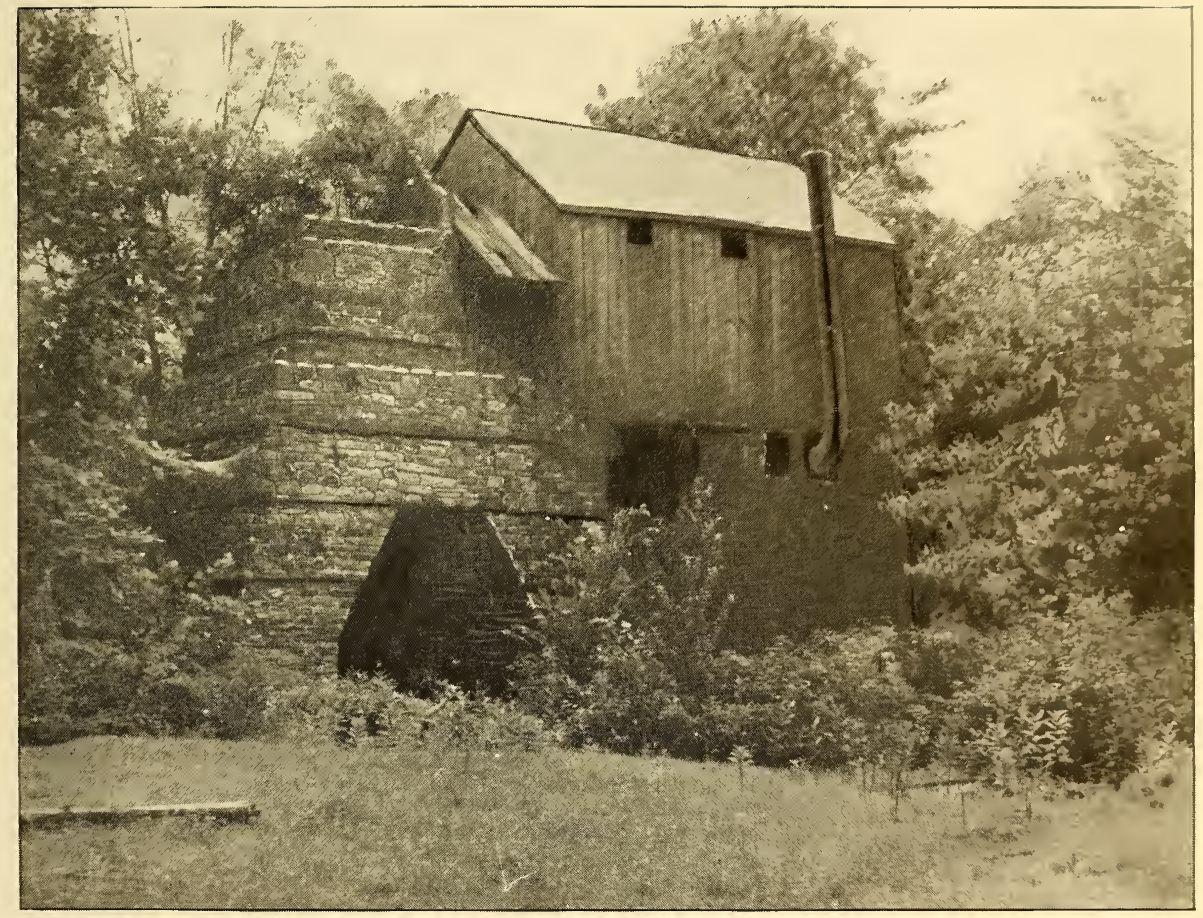

Hopewell Blast Furnace. Built by William Bird, i/59. 
/ 
toga Road runs into it, and from there to Lancaster, the Conestoga Turnpike.

In Irving's Life of Washington, ${ }^{1}$ we find an account of Washington's troops, after the battle of Brandywine, and before the battle of Germantown, in September, 1777 : "All day, and for a great part of the night they marched under a cold and pelting rain, and through deep and miry roads to the Yellow Springs, thence to French Creek. A weary march in stormy weather for troops destitute of every comfort, and nearly a thousand of them actually barefooted. At Warwick Furnace ammunition and a few muskets were obtained to aid in disputing the passage of the Schuylkill, and the advance of the enemy on Philadelphia."

Warwick Furnace is about seven miles from Hopewell, and at both of these places cannon were cast for the Revolutionary Army, and buried for safe keeping, when the arrival of the British was feared at the time of their advance up the Schuylkill River.

"On the 2 Ist, Sir William Howe made a rapid march high up the Schuylkill on the road leading to Reading, as if he intended either to capture the military stores there, or to turn the right flank of the American Army. Washington kept pace with him on the opposite side of the river up to Pottsgrove, about thirty miles from Philadelphia."2

The iron ore which supplied the furnace was derived from the Hopewell Mine, nearby. The fuel was charcoal. Some of the iron from the furnace was worked in forges at Birdsboro, four miles away. At a later date, we have this description, taken from a local paper. "The land connected with the furnace property was $5, \mathrm{I} 63$ acres, principally woodland. It was a cold blast one-stack furnace. Hematite and magnetic ores were used. Fifteen thousand

1 Page 214.

2 Irving's Life of Washington, p. 217. 
cords of wood were consumed annually in creating charcoal, and 170 men and boys were employed. The dwellers in this little town were iron moulders, furnacemen, wood cutters, charcoal burners and teamsters. Fifty years ago the village contained two hundred souls. The making of pig iron smelted from ore dug in underground mines, which were scarce two miles away, and converting this iron into ten-plate stoves was its chief industry. A charcoal furnace stood almost in the center of the village, at the foot of the Hopewell hills, and here the raw ores were converted into the, at that time, celebrated Hopewell stoves. These stoves were used in the kitchen and parlor and sometimes in the bed room, by rich and poor alike, until supplanted, some years later, by the cook stove, the range and the heater. Water from the Hopewell Creek furnished the motive power. A dam was constructed one quarter of a mile above the furnace, and from there the water for power purposes was directed into a race, and carried with slight incline to the big water wheel, with sufficient force to keep it in motion and drive the machinery of the entire plant."

To revert to the Revolutionary time;-we find two records of supplies forwarded by Mark Bird. ${ }^{1}$ On May I 8, I776, he addressed a letter to the Committee of Safety of Philadelphia, in which he made mention of muskets, etc., as follows:

"If the Committee of Safety will send me the price of Ioo muskets and accoutrements, with orders on the Commissioners to deliver to me such as they have ready on my paying what they cost, I am of the opinion in two weeks after the receipt of their orders and cash, I shall be able to deliver in Philadelphia the number mentioned. If each County will do the same, all the troops now in the pay of the Continent and this Province may be armed in three

1 Montgomery, Berks County in the Revolution. 

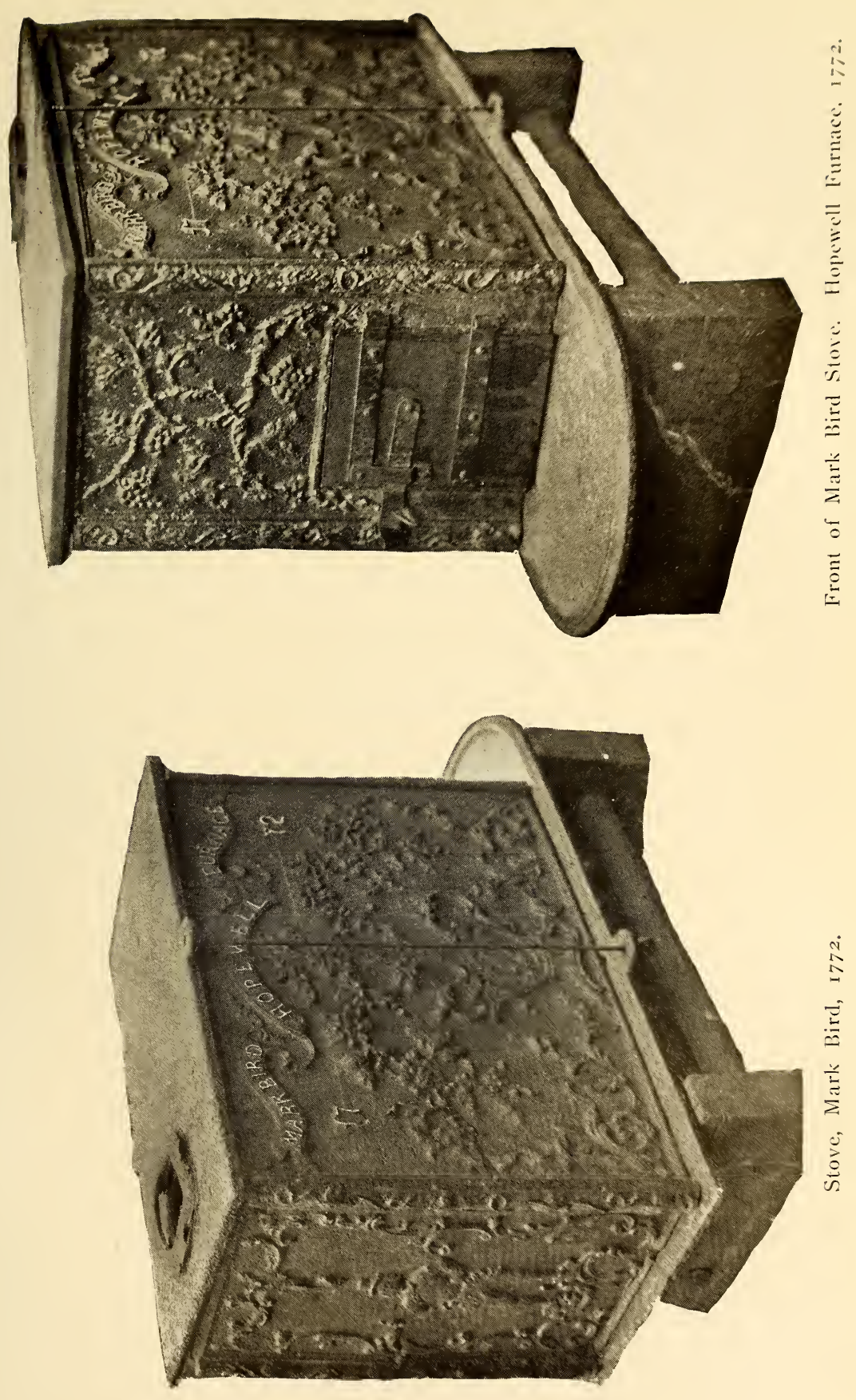

weeks from this date. I mean Continental troops in the barracks at Philadelphia. I am convinced you may collect in the different counties one thousand muskets, but few accoutrements. If you send the cash to the different counties to some person you can confide in, the arms will be ready immediately, but till you send the cash to pay the smiths, they will deny giving up the muskets. They like to see the cash without having the trouble of going so far as Philadelphia for it."

Also February I9, I778, a report was made to the Executive Council that Colonel Mark Bird had sent by water to Philadelphia one thousand barrels of flour during some time previous.

We also have an account in Montgomery's "History of Berks County" of Mark Bird's embarrassments. The first mention of Hopewell Furnace is suggested in a mortgage dated 1772 , made by him to his sister Maria and brothers William and James, to secure the payment of certain trust moneys. Becoming subsequently embarrassed he, in I 785 , was first compelled to borrow money (200,ooo Spanish milled dollars) from John Nixon, a merchant of Philadelphia, on a mortgage in which, among other properties, he describes the Birdsboro Iron Works and eight thousand acres of land, which included the Hopewell Furnace property; and then, finding he is insolvent, he, in I 786, transferred the property to Nixon in trust to sell and satisfy debts, etc. Nixon, accordingly, exposed it to public sale and in 1788 , transferred one-third to Cadwalader Morris and two-thirds to James Old, both iron masters. At that time the furnace lands comprised five thousand one hundred and sixty-three acres. In I790, Cadwalader Morris sold his one-third of the premises to Benjamin Morris, and in I79I, James Old sold his twothirds to the same person. In I793, Benjamin Morris resold the entire furnace property to James Old. After the 
lapse of seven years, Old became embarrassed, and was forced to yield up his title through the law and the sheriff to his creditor, Benjamin Morris, who bought it at the sale. This was in 1800 . In August, I 800, Morris sold it to Daniel Buckley of Lancaster county, Thomas Brooke of Montgomery county and Matthew Brooke, Jr., of Berks county for 10,000 pounds. The furnace was rebuilt in that year.

Matthew Brooke died in $182 \mathrm{I}$, after which time the Hopewell estate was divided, and one-third of the land was given to Birdsboro. The furnace and surrounding woodlands, farms, etc., are now the personal property of Mrs. Edward Brooke of Birdsboro, great-granddaughter of Thomas Brooke.

Hopewell Furnace to-day is not dismantled, although idle for many years. The iron master's house is in good repair, and the village street of iron workers' homes is much as it must have been in Revolutionary times.

Cornelia L. E. Brooke.

\section{Berks County.}

This forge was situated on Pine Creek, a branch of the Manatawny, four miles north of Oley Churches in District Township. "Its history is obscure. In I760 Rebecca Potts purchased at sheriff's sale a one-sixth interest in it. In 1773 , her executor sold it and a like interest in six tracts of land together containing eight hundred and thirty eight acres to John Old, an iron master of District Township. In 1778 , a part interest passed to Mark Bird." 1

1 M. L. Montgomery, History of Berks County. 


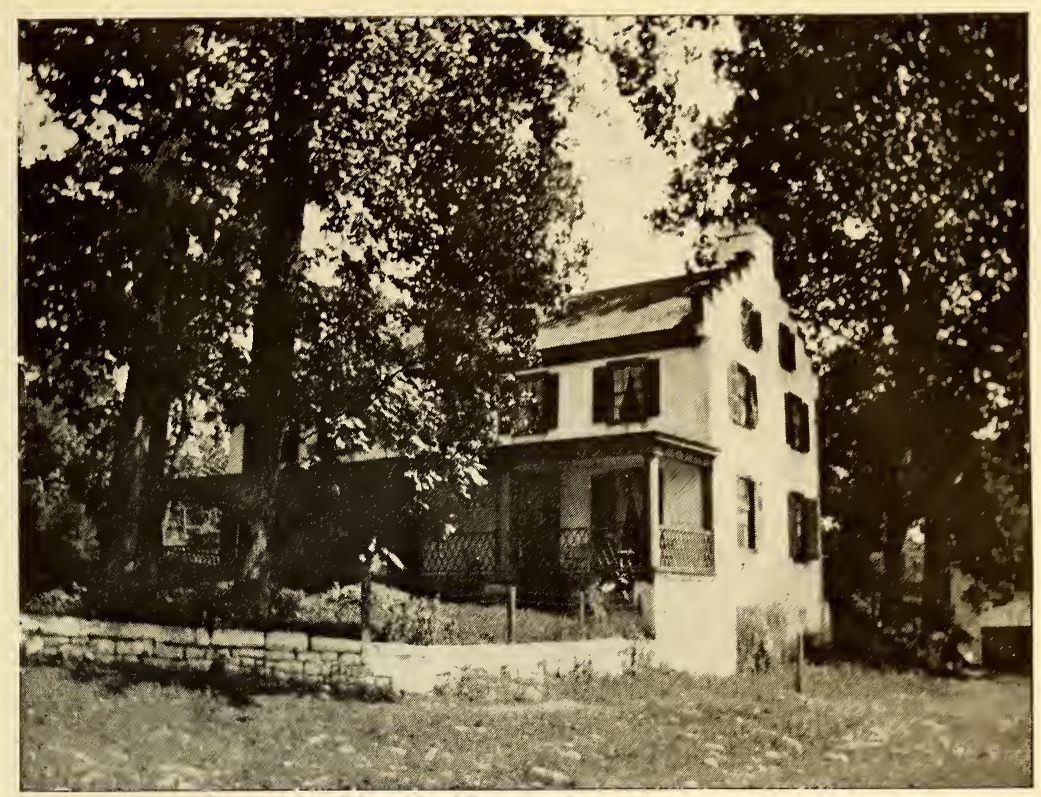

The Mansion, Hopewell Furnace.

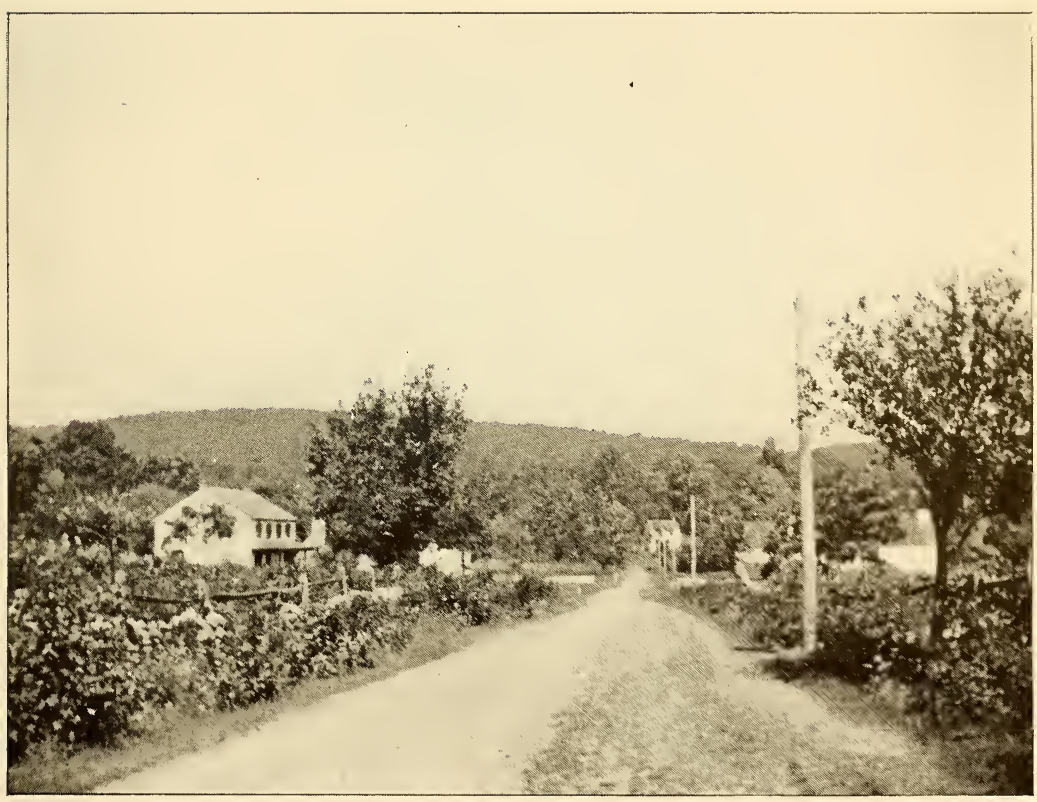

Village street, with workmen's houses, Hopewell Furnace. 

LANCAster County, later Lebanon.

On Hammer Creek, a short distance below the Lower Hopewell Forge, James Old, about I760, erected this chafery or bar iron forge, on land bought from David Caldwell, who had purchased it from Jacob Huber, the warrantee who had first owned Elizabeth Furnace. The name of James Old Stands high in the record of the early iron masters. A native of Wales, he developed rapidly into a man of enterprise and ambition. He married Margaretta, daughter of Gabriel Davies, and had at least two noted ironmasters as sons-in-law, Cyrus Jacobs, of Pool and Spring Forges on Conestoga Creek, and Robert Coleman, both having been in his employ. Coleman came to Speedwell as clerk from Quittapahilla, and made such a good impression on Old that when the latter removed in I 768 or thereabouts, to Reading Furnace, he took Coleman with him, and at Reading Furnace, in I773, Coleman married Anne Old. Margaretta Old married Cyrus Jacobs, and her brother William married Elizabeth, daughter of Henry Wm. Stiegel, on March 23, I773; and, in the endless sequence of “iron" marriages, William's son Joseph married later Rebecca, the only daughter of George Ege. James Old was a member of the Legislature in I79I-9293. His son William seems to have inherited Speedwell and to have lived here. We have the testimony of Hazard's Register that "the Olds were known as industrious, punctual and prudent ironmasters." 


\section{MARY ANN FURNACE.}

\section{YORK COUNTY.}

Three noted men, patriots and statesmen, were interested in the building and early running of this, the first blast furnace west of the Susquehanna,-George Ross the Signer, George Stevenson, one of the first lawyers in York county, and William Thompson, Stevenson's brother-inlaw, later distinguished as a general in the Revolution. From an entry in a "Mary Ann Wast Book, No. I. Jan. I 762"1 to the effect that "Cash was debtor to Messrs. Stevenson and Ross for $£ 50$ rec'd of George Ross last Decr." it is evident that this furnace was established in I76I.

The four-acre tract of land on which it was built had been leased by Ross, probably from John Hunseker, a German, who had it by grant from the Penns. Furnace Creek ran through the property which had been named by William Matthews, the Quaker surveyor, "Friendship." The title of the furnace "Mary Ann" is said to have been given by Ross to combine the names of his wife Ann Lawler, with that of his mother-in-law, Mary Lawler of Lancaster. This is just possible! In 1763 , the owners petitioned the York County Court for a road from their "furnace lately built at great expense" to connect with the road to the Conewago settlement, leading to Baltimore, and in 1766 , they petitioned for another road from their furnace to the Monocacy Road.

A few entries in the Mary Ann Account Books are of interest: "March 1762. To Cash Received of George

1 Manuscript Collections, Historical Society of Pennsylvania. 
Stevenson Esq. by William Thompson, L5" "Feb. I762. Store $D^{r}$. to George Stevenson Esq ${ }^{r}$. for I Hhd Molasses, rog gallons, I7. I I. 3. To $\mathrm{D}^{\circ}$ I Hhd Whiskey, $99 \mathrm{~g}^{\text {ns }} \mathrm{I} 2-7-6$ " There is also an "Account of Sundrys in Stock rec'd from George Stevenson Esq. viz, January I2-I762,-I Feather Bed Bolster and Pillows, I Sute courtains, I new Bed Tick, I Bed quilt, 3 Rugs, I Bedstead and Cord, I Trunk, I Canister, I Tea pot, 3 stone cups and saucers, 3 axes, I Table cloath."

In combination with the names and date of the Mary Ann Stove plate, the following entry seems to settle definitively the fact of Ross, Stevenson and Thompson being the first owners of this furnace:

"I promise to pay, or cause to be paid to Messrs. Ross, Stevenson and Thompson, ironmasters in Compa, the full sum of Jacob Miller's debt in Their Book at Mary Ann Furnace, the eighth day of January, I $763 \ldots$. . B. This note is on condition that any of the above Comp does not take said Miller before he gets to Lancaster.

$\mathrm{W}^{\Perp}$ SMITH

Test:

Thomas B. Barr-"

It is probable that this early partnership was of short duration; the ledgers preserved at the Historical Society of Pennsylvania, are naturally not consecutive as to date, and as George Stevenson removed permanently, in 1765 , to Carlisle, Cumberland county, where he took later an active interest in iron works, his connection with this furnace had then very likely ended.

On the stove plate made at Mary Ann Furnace in I 763 , the placing of the names of the proprietors is more than ingenious. The heart and tulip design so evidently beloved of the German workman, is there, as well as the 
arch and columns; "Mary Ann Furnace" in the middle line, is placed correctly. Then begins the trouble-to put Ross, Stevenson and Thompson in the cramped space left. The result is not exactly happy, but with effort one can decipher, on the upper line, "George Ross George Stev-" and as "William Thompson" fills the lower line neatly, the remainder of Stev comes in above, EN and SON on either side of the conventional tulip.

George Ross (1730-1779), son of George Ross, "the Rector," of Newcastle, Lower Counties, and Catherine Van Gezel, was of excellent Scotch stock (the family traced their descent from the Earls of Ross), a man of parts, who had had a classical education. He read law with his half brother John, and was admitted to the Lancaster bar in 1750 . Marrying in $175 \mathrm{I}$, he rose rapidly in his profession, which did not prevent an interest in the making of iron. The records show that he was an iron master when he died. In 1768 he was chosen a member of the Assembly of Pennsylvania, and from this time on, his short life of forty-nine years was crowded with civic and patriotic duties, while the state and general governments honored him with many positions of trust. He was a leader in the Assembly in encouraging measures for the defense of Pennsylvania against British encroachments. In $\mathrm{x} 775$, Governor Penn having written a message disapproving any protective measures on the part of the colonies, $\mathrm{Mr}$. Ross drew up a strong and convincing reply. ${ }^{1} \mathrm{He}$ was a steadfast friend of the Indian, serving as Commissioner at Fort Pitt in 1776 , a member of the Committee of Safety for Pennsylvania, Vice-President of the Constitutional Convention, Colonel of the First Battalion of Associators for Lancaster county, Member of the Continental

1 From paper by Charles Willson Peale, read before the Sons of the American Revolution. 


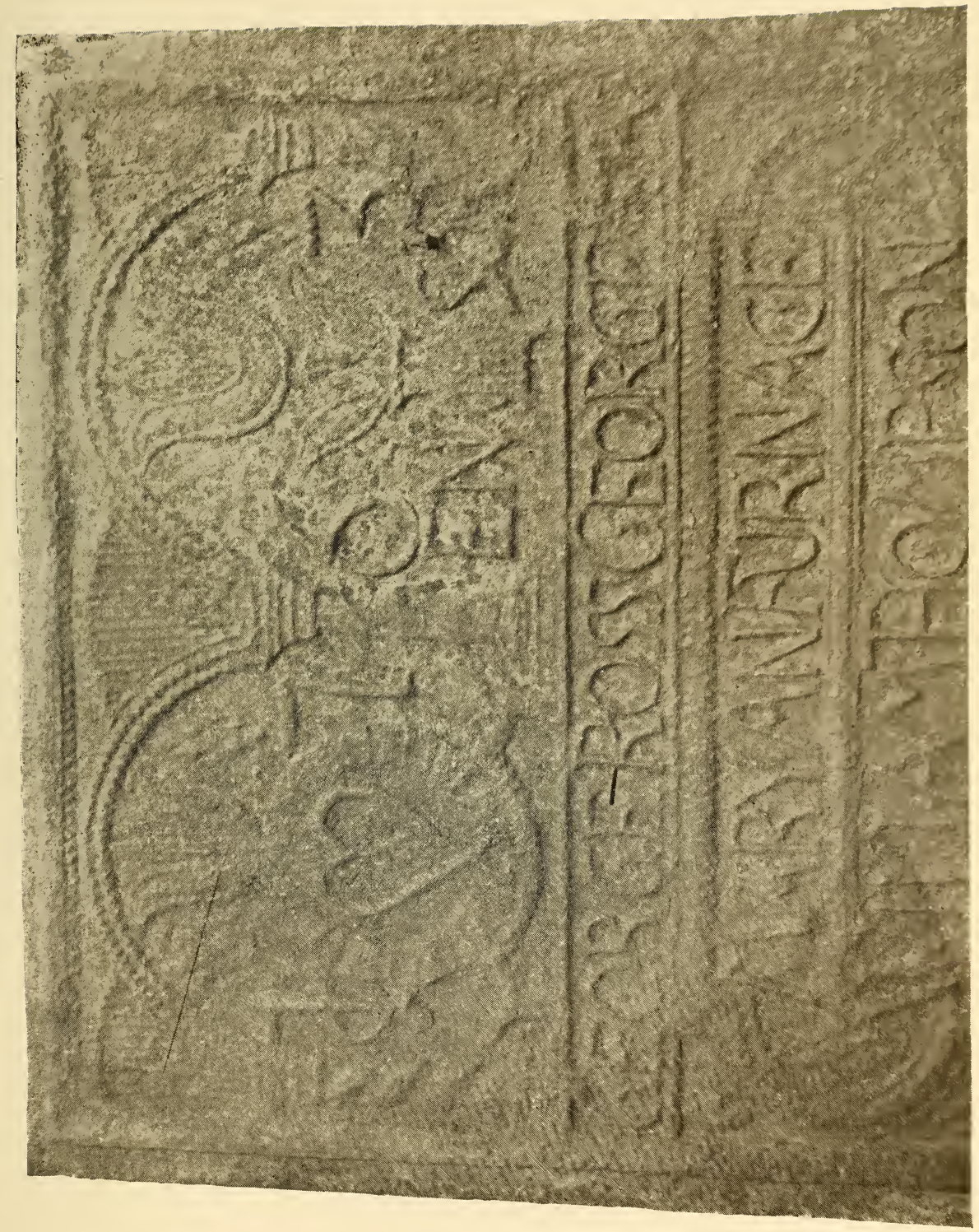

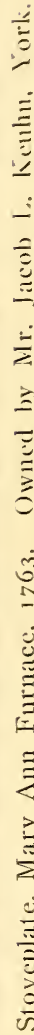



Congress,-and as a fitting climax, he signed the Declaration of Independence. He took his seat in Congress on the twentieth of July, I7.76, and he signed his name on the second of August.

George Ross as a signer did not sit in the Continental Congress from November 3, I 775, to July 20, I 776, in which interval the vote of adoption took place. Not alone from Pennsylvania, but from other colonies as well, delegates who occupied seats on the Fourth of July and voted for the adoption of the Declaration, ceased to be members before the second of August, when the signing took place, while some who were not members on the fourth of July, became members before the day of signing.

Ill health forced him to retire in January, 1777. On leaving office the citizens of Lancaster voted him a piece of silver to cost $£$ I 50, which he declined to receive. In the minutes of the Supreme Executive Council, Philadelphia, March I, I779, we find:

"Resolved, That the Honorable George Ross, Esquire, be commissioned Judge of the Admiralty of this State, under the late Act of Assembly: That this Board highly approve the firmness and ability he has hitherto shown in the discharge of his said office."

His house in Lancaster stood on the site of the present Court House, East King and Duke Streets, and his country home was a farm in what was then a suburb of Lancaster, now a part of the city, and called in his honor, Rossmere. He was a Churchman by inheritance, and was vestryman and warden of St. James' Church, Lancaster, contributing liberally to its various interests. Genial, kind and considerate, his sense of humor evidently lightened the cares of his strenuous life. He died on July I4, I779. 'A Philadelphia newspaper ${ }^{1}$ of July I 5 has this entry:

1 Pennsylvania Packet, July I5, 1779. 
"Yesterday died at his seat near the city, the Honorable George Ross, Judge of Admiralty of this state." He was interred in the church yard of Christ's Church, Philadelphia. ${ }^{1}$

From the Minutes of the Executive Council, Philadelphia, Wednesday, July I4, I 779:

"Information was received of the death of the Honourable George Ross Esquire, Judge of the Court of Admiralty, and an invitation to his funeral, to-morrow, at nine o'clock in the forenoon.

"Resolved, That this Board will attend the said funeral, and proceed from the Council Chamber to the late dwelling house in North St. Hudson's Square."2

A letter from Edward Burd to Jasper Yeates, July, I779, says :

"Poor Mr. Ross is gone at last. I was one of his Carriers. He said he was going to a cooler climate, and behaved in the same cheerful way at his exit as he did all thro the different trying scenes of life."3

George Stevenson, who was born in Ireland, in 17 I 8 , of excellent parentage, had been destined by his family to the ministry. He studied at Trinity College, but, not taking kindly to an ecclesiastical life, he left Ireland abruptly for America about I74I, where school teaching at Newcastle, Lower Counties, occupied him for a short time. He soon found a larger field for his capacities. "It is said that Thomas Cookson, deputy surveyor of Lancaster county, who surveyed the York townlands in I74I, never

1 Records of Christ Church.

2 Colonial Records, XII. 46.

3 Burd Papers, p. II2. 
returned the survey into office. To supply this deficiency George Stevenson resurveyed them in December I742."1 $\mathrm{He}$ is mentioned as a deputy surveyor under Nicholas Scull.

He married Jane Geddes, daughter of Henry Geddes, of Mill Creek Hundred, and moved to York in 1744. She died before $\mathrm{I} 748$, as Stevenson is mentioned in a deed recorded at Newcastle in that year, as "George Stevenson Esq. of York Co. Pa., as guardian of his sons Henry and George by late wife, Jane Geddes." Some years after, he married Mary Thompson, widow of Col. Thomas Cookson.

Many offices and honors in the newly created York county fell to Stevenson in I749. He was made justice of the peace, register of wills, clerk of orphans' court, prothonotary ${ }^{2}$ and clerk of quarter sessions, and in the next year was given a title which is probably unique in this country, and never used, before or since-that of Chief Ranger of the Province of Pennsylvania. To quote again the History of York County. ${ }^{3}$

"George Stevenson who was so much honored in the early days of this county, supported an office which is now unknown to our laws. James Hamilton, deputy Governor of Pennsylvania, constituted him $7^{\text {th }}$ January, I750, Chief Ranger of and for the County of York granting 'full power and authority to range, view \& inspect all our woods \& lands within the said county \& to seize, take up \& appropriate to our use all \& every such wild colts \& young horses, cattle \& swine as shall be found . . . not marked, etc.'"

There is another commission extant beginning "George

1 York County, by Carter and Glossbrenner, p. 37.

2 Commission now owned by his great-granddaughter, Miss Anne McClintock.

3 Carter and Glossbrenner, p. 138. 
the Third, etc. etc. to Robert Strettell, William Till, Benjamin Shoemaker, Lawrence Growden, Joseph Turner, William Logan, Richard Peters, Lynford Lardner, Benjamin Chew and Thomas Cadwallader Esq ${ }^{\text {rs }}$, members of the Proprietary and Governor's Council, and to Thomas Armor, John Blackburn, Patrick Watson, George Stevenson, John Pope, Hance Hamilton, Richard Brown, Hugh Whiteford, Michael Danner, Martin Eykelburger, Archibald McGrew, David Kirkpatrick and Abraham Noblitt of the County of York and Province of Pennsylvania, Esquires, greeting"- "which, with many words, goes on to make the above named, Justices, of the Peace, and of the County Court of Common Pleas etc.,一the date being $23^{\text {rd }}$ day of April 1761 - "and in the first year of our Reign" - It is signed by James Hamilton, and although under glass, is crumbling.

As his letters in the "Colonial Records" and "Archives" show, he was active in the troublous times of I $755-6$, and was appointed by Sir Jeffrey Amherst, then Commander-in-Chief of the King's forces in America, on a commission to audit accounts of Fort Duquesne.

On Scull's map of 1759 "Stevenson's" is just north of York. Removing about 1765 to Carlisle, he became one of the leading lawyers there, and was largely interested in iron-making ventures in the neighborhood, chiefly at Pine Grove, where, according to the records, he was an owner for eight or ten years from 1764 . He had one son, George, afterwards so well known for his service during the Revolution, and as a leading citizen in Pittsburgh and Wilmington; and three daughters:-Nancy, married to John Holmes of Baltimore; Catherine, married to John Wilkins of Pittsburgh, and Mary, who became the wife of Dr. James Armstrong, son of General John Armstrong. Of Brigadier General Thompson, the third of these 
early partners, our knowledge is limited, but full of interest. Born about 1736 , his birthplace is not known. He owned and lived upon, a farm near Carlisle, on the Conodoguinet Creek, and probably belonged by family or personal ties to the group of Scotch-Irishmen of the better class, who fought so bravely and persistently as frontiersmen, for "their hearthstones and their fires" against the slowly retreating but naturally vindictive Indians. When twenty years old Thompson served under Colonel John Armstrong in the noted fight at Kittaning, and in 1758 was made a Captain of Light Horse. The relations of these three partners were evidently friendly, as on March 29, I 762, Thompson (then Stevenson's brother-in-law) married Catherine Ross, a sister of George Ross.

"In the public library of Carlisle, Cumberland County, there is hanging upon the wall, the commission issued to

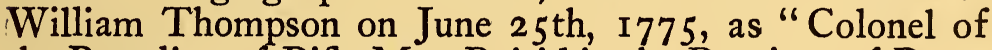
the Battalion of Rifle Men Rais'd in the Province of Pennsylvania" This was probably the first commission issued to a Colonel, and was certainly the first one that was issued and made operative by acceptance. I think that Colonel Thompson's troops were the first that were mustered in by order of Congress, and they were the first soldiers to reach Boston from south of the Hudson River."1

These riflemen are described by Thatcher as being re markably stout and hardy men, many six feet in height, dressed in white frocks or rifle shirts and round hats, and of great accuracy of aim, striking a mark with certainty at two hundred yards distance. One company, while on quick advance fired their balls into a target of seven inches diameter at a distance of two hundred and fifty yards. "On the 2oth April, I776, Congress urged Washington

1 Letter of the Hon. E. W. Biddle, Carlisle. 
to hurry troops destined for Quebec, and on the 2 Ist he despatched four battalions under Thompson of Pennsylvania as Brigadier." Of the Canadian campaign, a forlorn hope, indeed, though so bravely contested, no more interesting account can be found than that of Bancroft. For our purpose, a few words will suffice to tell of the disaster at Three Rivers:

"As day began to appear (June 8th, I 776) the Americans who were marching under the bank of the River were cannonaded from the ships; undismayed, they took their way through a thickly wooded swamp, above their knees in mire and water, and after a most wearisome struggle of four hours, reached an open piece of ground where they endeavored to form. Wayne began the attack ... they displayed undisputed gallantry, but being outnumbered more than three to one, were compelled to retire. ... Thompson and Irvine, who were separated from the rest of the party, were betrayed by the Canadians, and taken prisoners." 1

The next mention we have is "As prisoners, I 3 th June, General Thompson and Mr. Bird ordered on board Blonde ship of War," and on the twenty-fifth General Thompson transferred to the Union transport." 2 Although not regularly exchanged until October 26, I780, General Thompson was paroled and allowed to return to his family in $1777 .^{\circ} \mathrm{He}$ died at Carlisle September $3 \mathrm{rd}, \mathrm{I} 78 \mathrm{I}$ and is buried in the old graveyard. His widow Catherine drew a pension from the State. ${ }^{4}$

Definite information as to the later proprietors of "Mary Ann" is to be had in a Day Book for $1773 .^{5}$

1 Bancroft, V, pp. 291-298.

2 Journal of Colonel William Irvine, of the Sixth.

${ }^{3}$ History of Cumberland County, by C. P. Wing, p. 8ir.

4 Colonial Records, XV, p. 286.

${ }^{5}$ Manuscript Collections, Historical Society of Pennsylvania. 


$$
\text { L S d. }
$$

$\begin{array}{llll}\text { "March 31. To George Ross, for half } 357 & \text { Io } & 03 / 4 \\ \text { To George Ege for } d^{\circ} & \text { " } & \text { "6 } 61\end{array}$

Then in a Day Book, I774 "George Ross and George Ege, joint Proprietors." And on March 3Ist, I775, "George Ege, Dr. to George Ross, for I year's rent, Furnace and Forge-L 500.

L S d.

$\begin{array}{lll}\text { To George Ross for half the profits } & 36 \mathrm{I} & 5 \\ \text { George Ege for t'other half } & 36 \mathrm{I} & 5\end{array}$

According to entries found in these books the relation between this furnace and Spring Forge on the Codorus, some miles above York, were close, and possibly the "Forge" mentioned above was Spring Forge; as in some books the entries for either are mingled indiscriminately. For instance, March, I772, "Spring Forge Dr. to John Giger L66 SI-"

Like most of the furnaces during the Revolutionary period "Mary Ann" manufactured cannon balls and grape shot for our army and navy. Some balls were found on the farm where the furnace had been. They varied in size from a minie ball to a four-inch cannon ball. In operation for over fifty years, and having passed through the ownerships of John Steinmetz and John Brinton, both of Philadelphia, and finally of David Meyer, these noted iron works ceased to exist early in the nineteenth century. In the pits where the charcoal was burned, the soil is yet black along the hillside, and the race through which the water passed, is still there.

Caroline Hale Steinman. Augusta M. Longacre.

1 See Charming Forge. 
Berks County.

A valuable ore bed called the "Moselem mine" was known as early as 1750 to the iron workers of the Manatawny region, and contributed of its rich deposits to the Oley, Spring and other forges.

Finally a forge was erected on Moselem Creek near by, in the township of Richmond, Berks county. The date is not known, but it must have been considerably earlier than 1767 .

For we find from the records that in August, 1767, "Jacob Shöffer of Manatawny, yeoman, for the consideration of five hundred pounds sold one undivided fourth part of a tract of land containing one hundred and seventy five acres situate on the Moselem Creek in Richmond township, also one fourth part of all forges, mills, etc thereon erected, to Christian Lower of Tulpehocken, a blacksmith."1

The forge is also referred to in a description of a road laid out in 1768 leading from the Moselem Forge to Reading. The records of its history are very meagre.

1 History of Berks county, by M. L. Montgomery. 


\section{SPRING FORGE III.}

\section{YORK COUNTY.}

It seems evident that this forge on the Codorus, some miles above York, was in close relations with the Mary Ann Furnace, and was probably owned by George Ross, with or without the other partners. A "Spring Forge" is frequently mentioned in the Mary Ann Ledgers and account books and the expression "at the Spring" is used. Entries in a Mary Ann Ledger run:

"March 1772. Spring Forge to John Giger Dr. £66-ISpring Forge to Edward Musgrove Dr. 5-I-4"

Michael Ege, George Ege's brother, afterwards of note as an iron-master in Cumberland County, worked here as a youth; and married Dorothea Wolff, of this neighborhood. One authority says briefly, of this forge, that it was built to take the place of Peter Dick's bloomary, and was active many years. 


\section{CARLISLE IRON WORKS.}

\section{Boiling Springs, Cumberland County.}

An early forge, built probably after 1750 , is said to have preceded this well-known furnace. In 1762 , Richard Peters, of Philadelphia, obtained a patent for three hundred and eighty-eight acres of land called Boiling Spring, and immediately executed a deed to John S. Rigby and Company for twenty-nine acres "on which they had already commenced the erection of a blast furnace." At the same time they bought two ore banks at the foot of South Mountain, and shortly after added sixteen hundred and fourteen acres of land, so situated that they embraced all the land between these ore banks. These tracts were then called the Carlisle Iron Works. Shortly after, John Armstrong and Robert Thornburg became part owners, and to Thornburg's skilled management much of the success of the works is due. He died in 1774 .

As so often happened in Pennsylvania, the iron-making interest of a father, in this case Anthony Morris, $3 \mathrm{rd}^{1}{ }^{1}$ the well-known iron investor, was reproduced here in his sons, Samuel and John, who with Francis Sanderson and Robert Thornburg bought this furnace from Rigby in 1764 . It is said that in 1768 Michael Ege, Amos Stilwell and Robert Thornburg bought out the former owners, and that finally in I 792, Michael Ege became sole owner. ${ }^{2}$ Boiling Springs produced twelve to fifteen tons of metal a week, making as did most of the early furnaces "loops" and blooms chiefly, but also stoves, fire backs and hollow ware. The illustra-

1 See Spring Forge and Colebrookdale.

2 Blast Furnaces of Cumberland County, by B. K. Goodyear. 


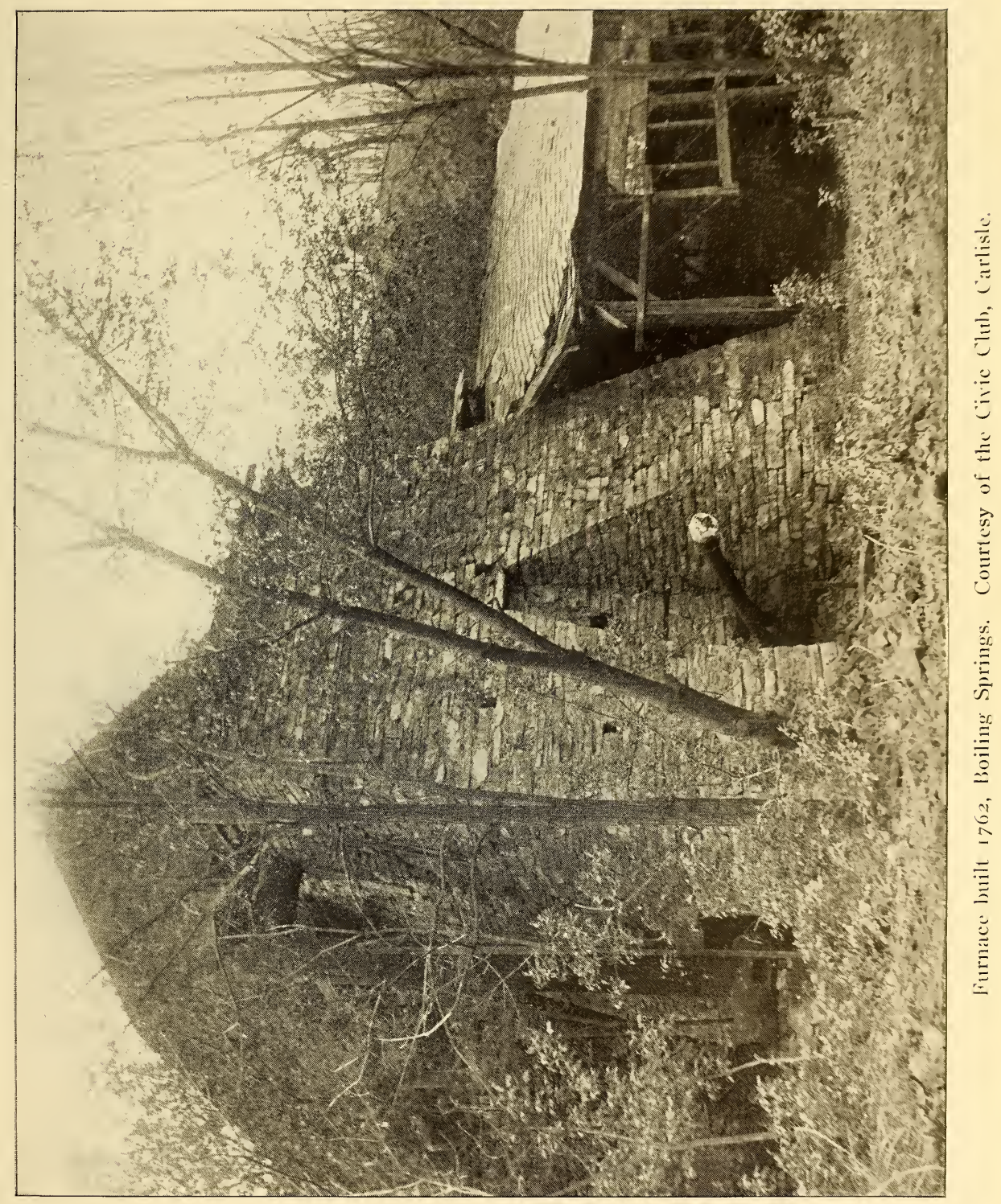






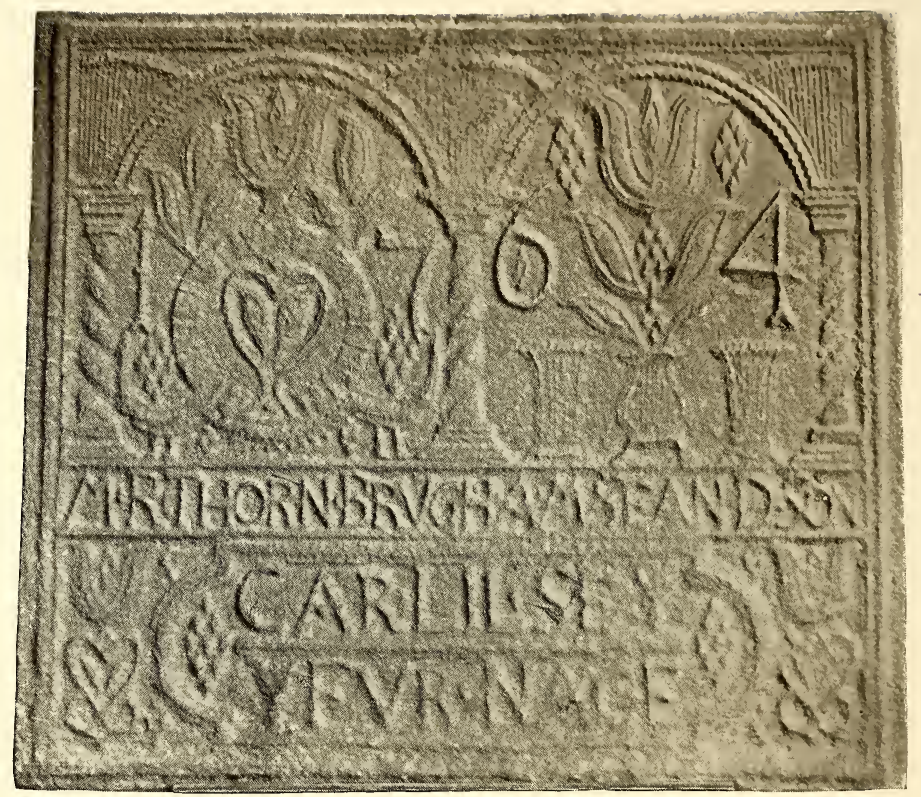

Stoveplate cast at Carlisle Iron Works, I764. Owned by the Historical Society of Pennsylvania. 
tion, a stove plate, shows the usual irregular and quaint style of inscription of the travelling German workman, and may be deciphered thus :

\section{764}

Mr. Thornburgh,-A for Armstrong. M for Morris. and Seandson for Sanderson. It looks as if Thornburg and Sanderson loomed larger in the minds of the workmen than did either Armstrong or Morris, but in one way or another all the partners are commemorated.

Writing to James Young, Esq., Paymaster, from Philadelphia on January 28, I 764, John Penn, Esq., Lieutenant-Governor, says: "When you arrive at Carlisle you will immediately engage the gunsmiths or armourers in and about that place, and order them to repair such arms of the Provincial troops as are out of order, as fast as they arrive there."1

In 1776 and throughout the War, anthracite coal was taken in arks from the Wyoming mines, above WilkesBarre, down the Susquehanna, to the Armory at Carlisle. The first cargo sent down the Susquehanna is said to have been the first shipment of anthracite coal made in this country.

"During the Revolution the Continental Congress established and maintained an Armory at Carlisle where muskets, swords and wrought iron cannon of great strength were made." 2 In an unfinished paper by the late' C. P. Humrich, Esq., on "Washingtonburg" the early name for the Carlisle Barracks, it is stated that a company of Artificers were stationed there from I777 to I78I and probably later, whose "duties were to cast cannon, bore guns, and

1 Rupp's Cumberland County, p. 4or.

2 Jenkins, Pennsylvania Colonial and Federal. 
prepare ammunition for the use of the Army." A company with similar duties was also located in Philadelphia. ${ }^{1}$

And just here let us try to clear up the insistent traditions of the wonderful wrought iron cannon of Cumberland county. Many of the books on Pennsylvania mention them, with varying details. Briefly, the tale is, that William Dunning of Middlesex, in this county, made, presumably about I776, two wrought iron cannon of great strength, one of which was in use at the battle of Brandywine, was captured by the British, and deposited finally in the Tower of London. The story runs that the British government offered a large sum of money and an annuity to the person who would instruct them in the manufacture of that article; Dunning's patriotism, however, withstood the alluring offers. $\mathrm{He}$ attempted another and larger cannon, but could get no one to assist him who could endure the heat, which was so great as to melt the lead buttons on his clothes. This unfinished piece is said to have a resting place, now, near Carlisle, but just where, no one knows.

William Dunning died December I9, I830, aged 93, at his home near Newville. ${ }^{2}$ To settle the question of the wrought iron cannon reposing in the Tower of London, the authorities there were written to, who promptly replied, in the following courteous letter:

\section{"The ARMOURIES \\ TOWER OF LONDON \\ LoNDON, E. C. \\ I2. 3. I3.}

"Madam:

"The Governor of the Tower has handed me your letter of the 4th March. I regret to say that I cannot trace the cannon which you mention.

1 The Hon. E. W. Biddle, Carlisle.

2 Hazard's Register, VII, p. 48. 
"It is more than probable that it was destroyed in the fire of October 3oth, I84I, which destroyed the Grand Storehouse which contained the "Train of Artillery." "Yours faithfully, Charles ffoulkes

Mrs. Longacre

Curator

In any event-we have the glory of the tradition, and possibly a cannon.

Michael Ege, brother of George, the noted ironmaster of Berks county, was born 1753, and brought up at Charming Forge, by his Uncle Stiegel. He was employed first at Spring Forge, York county, and at the age of nineteen married Anna Dorothea Wolff, daughter of a well-todo German farmer. Soon after his marriage he settled at Boiling Springs, Cumberland county. By 1786 he was part owner of the Carlisle Iron Works, there, and in I792, became sole owner. A few years later he built a mansion, beautiful for situation, with graduated terraces leading down to the Boiling Springs lake and stream. He brought up three sons in the iron interest, and had several other ventures himself, notably Pine Grove Furnace. He died at the age of sixty-two in I 8 I 5 , leaving a comfortable fortune to his children.

Augusta M. Longacre. 


\section{Berks County.}

About the year 1760 a valuable deposit of iron ore was found on Furnace Creek, a branch of the Little Manatawny, in Oley township, a short distance north of Friedensburg, and near the line between Oley and RuscombManor townships. This ore was doubtless used in the forges in that vicinity, notably the "Oley" and the "Spring." A few years later, probably in 1765 , a furnace was erected near the mountain, known as the Oley Furnace. It was built most probably by Dietrich Welcker, ${ }^{1}$ an iron master of Skippack, and it is possible that William Maybury was a joint owner in the beginning. In I768 the furnace was certainly in existence and in operation, for Welcker at that time borrowed one hundred pounds from John Lesher, iron master, of Oley Forge, and executed a mortgage to him, in which the furnace is mentioned, and five tracts of land.

During the Revolution Oley Furnace became the property of General Daniel Udree, and was carried on in connection with the Rockland Forges situated several miles to the northeast. Eventually the works passed into the hands of the Clymer family, and was known for some time as the Clymer Iron Works. A plate with " 1770 " on it is built into the stack, but it must relate to some other fact than the beginning of the furnace. Beside that obtained from its own mine, ore was supplied to it from the Moselem mine, in Richmond township, lying eight miles to the northwest. $^{2}$

${ }^{1} \mathrm{He}$ may have been a son of Dietrich Welcker, who in 1756. kept an inn at Skippack, Montgomery county, where the sign, a Weeping Willow, hung for many years.

2 Berks County, by M. L. Montgomery. 
CODORUS FORGE AND FURNACE.

\section{YoRk COUNTY.}

A furnace and forge were erected by William Bennett on Codorus Creek near its junction with the Susquehanna, in Hellam township in 1765 , and continued under his management until May, I77 I, when they were sold by the sheriff to Charles Hamilton. Hamilton in turn sold them, November, I77 I, to James Smith, the Signer, who besides his mental capacity and learning had a great fund of humor. This seems to have sustained him in that bitter school of experience, iron making. Many were the gibes and jests he directed against the two managers he had at Codorus Forge. One, he said, was a knave, and the other a fool. After losing $£ 5000$ in this venture, James Smith, in April, I778, sold the forge and furnace to Thomas Neil. ${ }^{1}$ These works are said to have made ammunition for the army during the revolution.

1 York County, by Carter and Glossbrenner. 


\section{WINDSOR FURNACE.}

\section{Berks County.}

With the enterprising industry so characteristic of the German, many of the settlers of Berks County undertook almost single handed the manufacture of iron wares, most of them of simple domestic use, but cast in forms of real beauty.

One of these settlers began his work so early that his little enterprise gave its name to the pretty stream he made use of under the shadow of Blue Mountain, and which is still known as "Furnace Creek." In course of time the water power was further utilized; and when, in 1768 , the estate was sold to Jacob Winey, of Philadelphia by one Henry Moll, who had bought it at sheriff's sale from Frederick Delaplank, a reputed iron-master, it is described as comprising one hundred and seventy-six acres of land, together with a forge for the manufacture of bar iron, a grist-mill and a saw-mill.

After this sale, work at the forge seems to have been discontinued for a time, and we next learn of the establishment of a small charcoal furnace on the site, by Valentine Eckert, an enterprising iron master in the northern part of the county. Later George Reagen became the manager, and the plant was operated in connection with Union Furnace and the forges in Albany township. ${ }^{1}$

Though the furnace has had a checkered existence, and has been out of commission at times, it is entitled to special consideration for remarkable artistic work, done early in

1 Berks County, by M. L. Montgomery. 


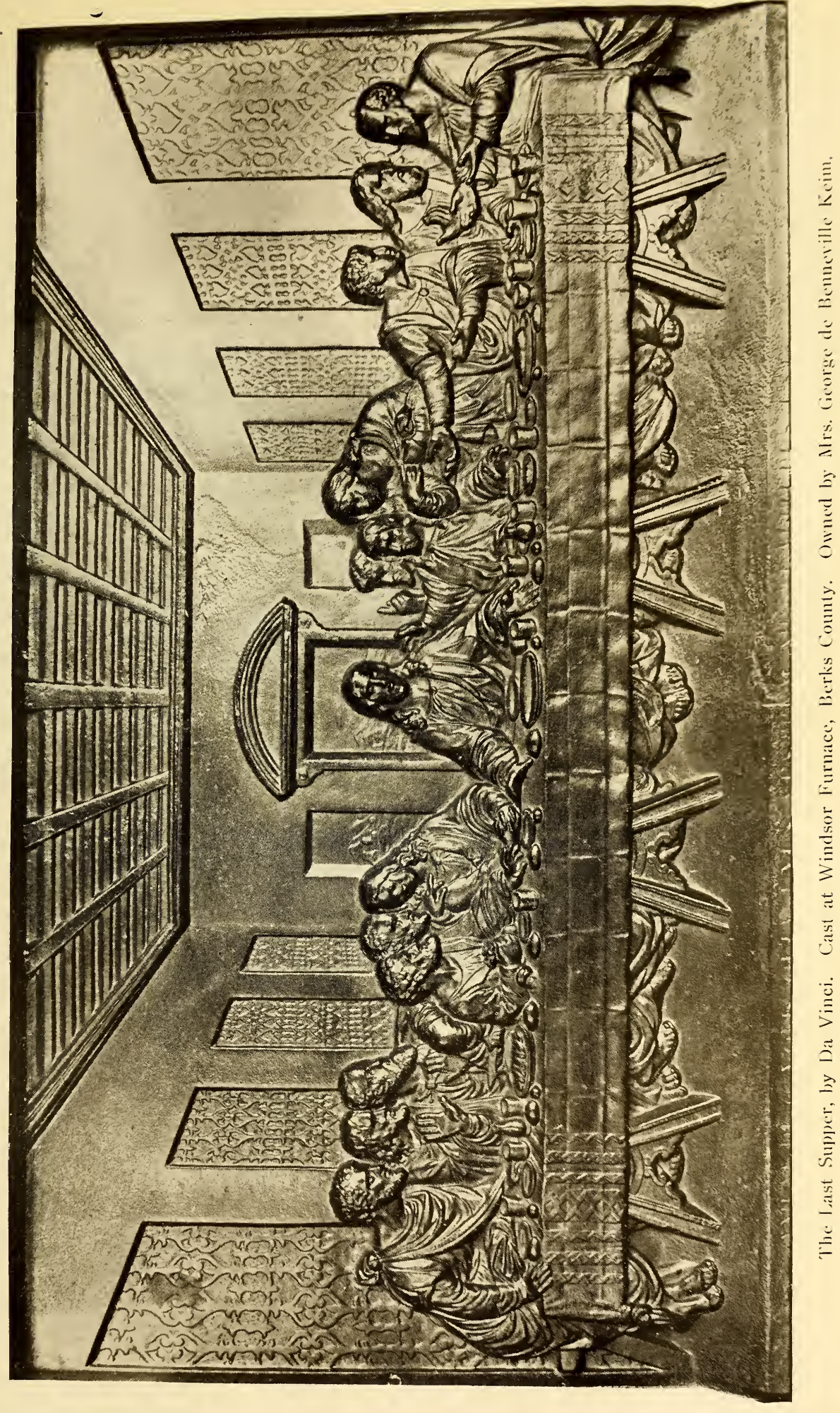






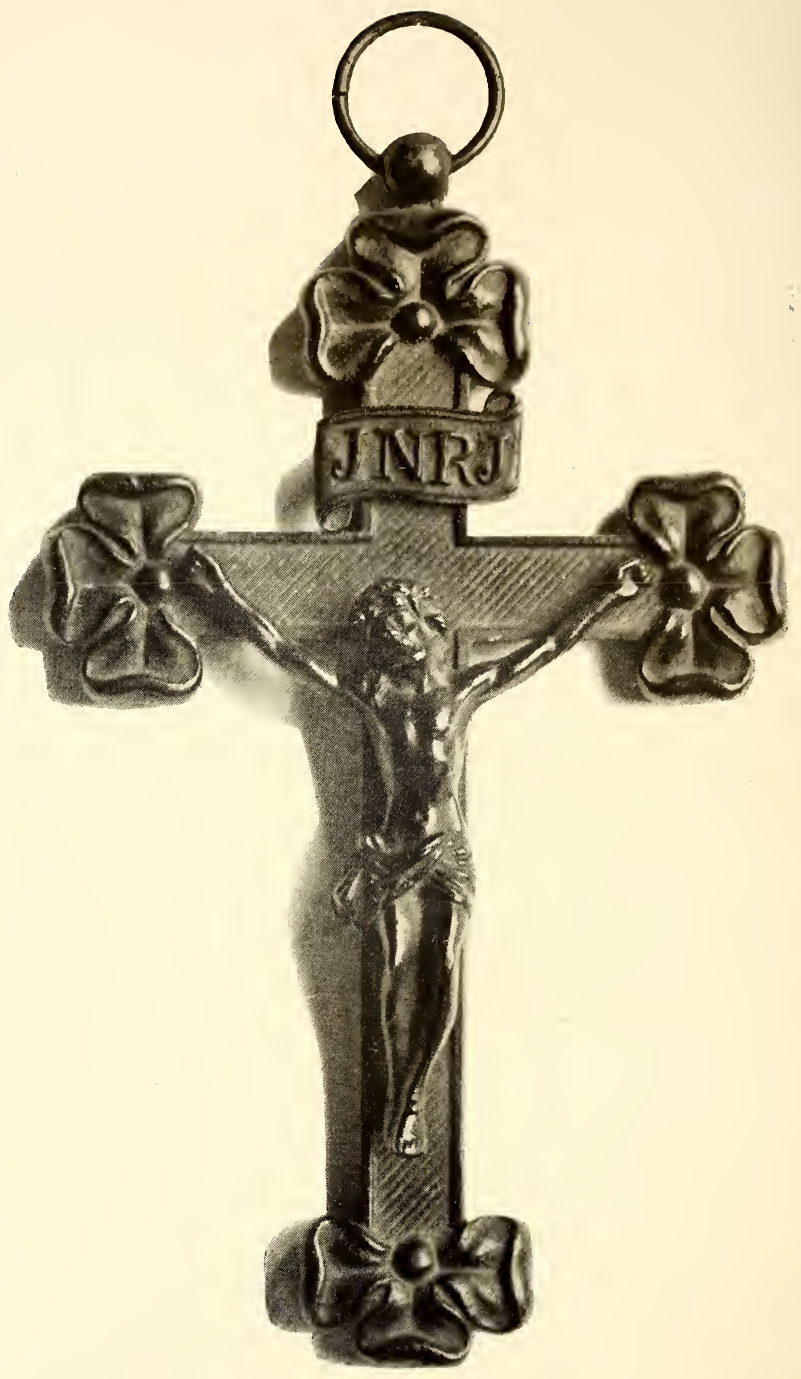

Crucifix cast at Windsor Furnace, Berks County. Owned by Mrs. George de Benneville Keim. 
the last century, under the management of Jones, Keim \& Company. This firm made castings of various kinds with definite artistic intention, one of its most admired productions being a copy of the Last Supper after the celebrated painting at Milan by Leonardo da Vinci. This was presented to the Philadelphia Exchange by D. M. Keim. Cast directly from pure ore, in common sand, and oiled, it was the first attempt to bring to perfection castings of this description. A crucifix, also of great beauty, is given among our illustrations, as showing the height to which Pennsylvania finally attained in this art. While this work was done long after our colonial date, yet the furnace which had the honor of accomplishing it was distinctly a colonial furnace; so, technically, we are within our limits, and the beauty of these castings is an ample excuse, if any is needed. Mr. George May Keim (I805-I86I), a well-known Philadelphian, was an owner of Windsor Furnace, and a member of the Keim family so long identified with the State. 


\section{GULF FORGE.}

\section{Montgomery County.}

Gulf Forge, on Gulf Creek in upper Merion township, Montgomery County, near the village of Gulf Mills, is mentioned as existing in I768, and shown on Scull's map of 1770 , but no trace of it is now to be found, nor is any information obtainable on the subject. By those who know this beautiful neighborhood, a description of "The Gulf," from Buck's History of Montgomery County, will not be considered too irrelevant.

"The Gulf is where the Gulf Creek passes thro' the Gulf Hill and for the purpose of a passage, has cleft it to its base. The stream and the wood by its side wind thro' it somewhat in the shape of an S, and at the narrowest part there is just room enough for both, the whole width not being more than forty feet. The hills on either side are pretty steep and are covered with rocks, bushes, and trees to their summits. Near the old Gulf Mill on the South side of the entrance, a rock juts out at the roadside to an elevation of about fifteen feet, which has sheltered people from the rain." 


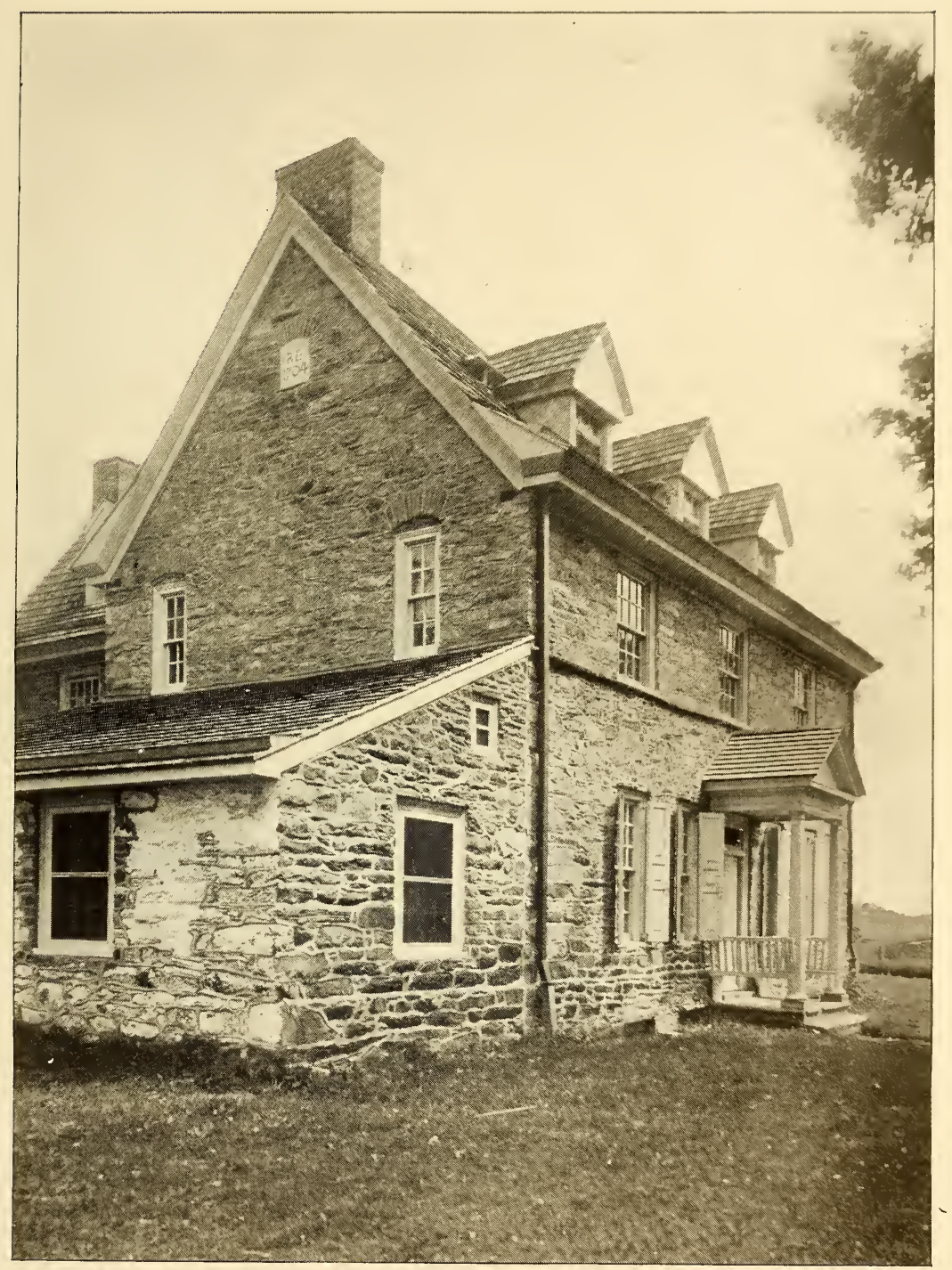

Harriton, Bryn Mawr. Showing cheese-room. Residence of Charles Thomson, Secretary of Continental Congress. Now owned by George Vaux. 



\section{Cumberland County.}

The furnace I knew best was Pine Grove, with its twenty-seven thousand acres of woodland, nestled in the South Mountain, midway between Carlisle and Gettysburg, about fifteen miles from either. In placing charcoal furnaces, streams and forests were the first consideration,the one to furnish power, and the other to provide charcoal. The next essential, iron ore, could be hauled from adjacent mines. At Pine Grove this was found in the surrounding hills. A vivid recollection remains with me of the working of the furnace, the molten iron and all that, but as the early process is given in our introduction, I shall not repeat it. In making charcoal the chestnut, oak, and hickory of the forest were cut into prescribed lengths by the wood-cutters, to be later piled on end in a cone-shaped stack about six feet high and slowly charred for a week or so, for use in the furnace. The wagons that brought it in, were long with high sides, and drawn by six mules. Each board of the bottom was moveable with a heavy iron ring in the end. These were drawn by detaching the leading mules from the tongue of the wagon and hooking their chains into the rings in the board at the back of the wagon and thereby drawing out of the bottom a board at a time, which deposited the coal where it was wanted, at the "coal house."

Furnaces were often called by women's names, a compliment personally to members of the family, and the fires, when convenient, lighted by women. I know of an in- 
stance during the Civil War, when, at the "blowing in" of a furnace great care was taken not to light the fire with a Democratic newspaper! When a bride visited a furnace, her slipper was taken (ladies did not wear shoes) and kept by the men until she promised a "treat."

While my recollection, naturally, does not go back to colonial days, I am sure the life was not changed in any particular from the building of the furnace in 1770 to the begininng of the Civil War. My personal knowledge begins with 1848 . There were no railroads, and a journal of my grandmother's records long journeys to Baltimore or Philadelphia in carriages, or on horseback, with servants in charge of the luggage. Our old carriage at Pine Grove had a large trunk rack behind, which was strapped up against the back when not in use.

Iron was conveyed from place to place in wagons or on the backs of mules. In some instances the bars of iron were bent to fit over the mule's back. Canals were a welcome improvement in transportation, till railroads came.

Laborers at the four furnaces in the South Mountain, Pine Grove, Mt. Alto, Caledonia, and Katocktin in Maryland, were nearly all English; there were few Irish names and almost no Germans. They were the same race as those found in the West Virginia and Tennessee Mountains; the mountains are of the Blue Ridge chain in which the old furnaces were, and the lives they lead to-day are just as I am trying to describe, except for the feuds. At the Pennsylvania furnaces they were tamer and gentler people, from the influence and contact with the family of the Big House, but their primitive instincts and superstitions were the same. The Tennessee mountaineers are said to be of the purest, most unmixed blood in this country and are a most interesting people. Craddock uses a word "survigerous" 
-the Pine Grove people said "savagerous" for "irritated."

Mr. Jas. M. Swank, in his "History of Iron," tells us: "The authority of those old Pennsylvania iron masters was indeed baronial, but it was also patriarchal. A tie of common interest closer than exists to-day under similar relations, bound master and workman together." They were dependent on the Big House for everything concerning their welfare, and were looked after in their births, marriages and deaths, with most affectionate interest, giving in return unbounded loyalty and affection. An old man I know after an interval at other work, thought he would return to a furnace, and told me later he could not stand it,- he was only known by a number and was simply part of a machine,- - this describes modern conditions, - the old personal element no longer exists. To quote again from Swank-those "good old Colony Times, when Pennsylvania was still a British province, are gone and their medieval flavor, their picturesqueness, and their placidity, are also gone."

The cottages of the laborers were logs and plaster, with stone chimneys, simply furnished with painted wooden furniture and huge feather beds, and their prosperity was gauged by the number and variety of their patchwork quilts. There was a good deal of the joy of life in the making of these,- the various patterns had names, "The Garden of Eden," "Sunrise," etc. The designs took months to accomplish, and the final quilting was an occasion of merrymaking. The food and clothes of the people were provided at the "store." (The wagons that took away iron, brought back these necessities.) Calico for their dresses and sun-bonnets, linsey-woolsey (a rough woolen material) for their petticoats; they spun and dyed the wool for their stockings which they knitted themselves. 
Coarse, heavy shoes came from the "store," also flour, "flitch" (salt pork), molasses and tobacco. Many of the women smoked. The more thrifty of the families had cows, which roamed at will, procuring such food as they could, and at milking time they were easily followed and recovered, by the sound of their tinkling bells. Each cottage had a garden, and they all had chickens and eggs; and again, the more thrifty had pigs.

Apple-butter boiling, spelling bees, in addition to the quilting bees, made up their amusements. These festivities generally ended with a dance, on the sanded floor, when the young men arrived to take the young women home. The music was provided by a self-taught fiddler with probably a home-made fiddle, and the lights were tallow candles. Brides drove away with their swains to the nearest " preacher," to be married, and were greeted on their return by a "charivari," or as they called it a "calathumpian," ending in a "treat."

These mountaineers were very religious, and held what were called "protracted meetings" on which occasions they all became converted, or as they expressed it, "found religion." But as they had generally lost it when meeting time came around again, there were always candidates for the "mourners' bench." Most of them were very restless and loved the excitement of a flitting, with neighbors all gathered in, and a feast at both ends of the line,to say nothing of the six-mule wagon with a turret of gay bells and red flannel streamers on the harness. The four furnaces I have mentioned as neighbors, were visited in turn, but they were people of strong affections, and a little grave on the hillside often held them, or brought them back. It was a sweet God's acre, in the primeval forest, with the sunshine slanting between the big trees standing guard, and year after year, covering those sleeping there 
with their softly falling leaves. It was a strong magnet for them all, as you see by the interesting tales of the Tennessee Mountains. It was the custom, after a burial, for all the friends for miles around, to return to the house of the mourning family for the "funeral baked meats," and great were the preparations, and many and various were the pies and jams.

Christmas Day was always looked forward to, with much excitement, for the children on the place got all the apples and cakes they could carry when they came to visit the Children's Tree, at the "Big House," and the heads of families longest on the place were given their Christmas dinner. Of course there were not then the endless books and toys that children have now. Our old rag dolls had clean faces and new dresses for the occasion, and we loved them dearly and were proud of their new looks.

The old house was very large, and the situation beautiful. We had only wood for fuel, and the big blazing fireplaces are a charming recollection. We were lighted by lard lamps except on occasions of entertaining, when candle-boards were fixed over each door-way, decorated with evergreens, and a row of wax candles in each. Part of the work of the house-hold was moulding candles, pounding spice with a mortar and pestle, and cutting the white sugar which came in a "loaf." In the nursery a thing called a "witch" made a night-light,-it was a piece of paper twisted and lighted, floating on melted lard. All house supplies were bought in large quantities,-barrels of crackers and sugar, boxes of tea and coffee, and wines in proportion,-for there were no shops where such things could be obtained. Nutmegs were sold for their weight in silver. Flour was ground at the mill on the place, for there were many acres under cultivation to supply the families and animals. The haymaking was done by a long 
line of mowers, twenty or more, with scythes, stepping in a rhythmic movement; and in the same way, the wheat and oats were cut with "cradles." There was a carpenter shop and a blacksmith shop; and the trade of wheelwright was in much demand for the only power known was water power which meant a big wheel. We are told that Egyptains 1500 B.C. blew their furnaces by artificial wind derived from treading on goat skins filled with air. Modern furnaces are operated by powerful gas engines.

No one thought the distance from Carlisle too great for driving, so there was always plenty of company, and of course they came for the night or for several days. The old garrison in Carlisle added too, to the gaiety. In those days, when there were fewer people in the world, all persons of consequence knew each other, if not actually, at least by reputation, and they were expected to stop if they came into the neighborhood as a matter of course, and it was a source of mutual pleasure and satisfaction.

The recorded ownership of this old furnace dates from a Proprietary Grant, 1762 , for four hundred and fifty acres on Mountain Creek to Thomas Pope; thence by deed, I764, to George Stevenson, who, in I772, conveyed it to Finley McGrew, who in turn, I773, conveyed it to Jacob Simon. The furnace was built probably in 1770 by Robert Thornburg and John Arthur. In I782 Jacob Simon conveyed Pine Grove Furnace and land to Michael Ege and Thomas and Joseph Thornburg, sons of Robert. In I803, Michael Ege became sole owner. ${ }^{1}$ Operated chiefly by the Ege Family until 1838 , the property then came into the hands of Mr. C. B. Penrose and the Hon. Frederick Watts. Finally, in I 845, Mr. Wm. M. Watts took possession, and operated furnace, forge and farms

1 Ege Genealogy, pp. 92 and 93. 
very successfully until $\mathrm{I} 864$, when Mr. Wm. G. Moorehead became the owner.

"Perhaps the most royal hospitality of all dispensed at any residence in the county was that of the Peter Ege family who lived at Pine Grove. Connected by ties of blood and friendship with Carlisle and its people, $\mathrm{Mr}$. Ege and his wife, a Miss Arthur of Virginia, have left many traditions of their princely manner of entertaining. In later years the spirit of hospitality was fully sustained by William M. Watts, Esq., who succeeded Mr. Ege in this place of delightful memories, so picturesquely located on the sloping sides of the South Mountain, and so interwoven with the social life of the town as to have been practically a part of it." 1

It is pleasant to be able to say that this fine property has fallen into good hands. Some years ago it was purchased by the State Forestry Association.

Sarah R. Watts Rose.

1 Carlisle, Old and New, p. 139. 


\section{SALFORD FORGE.}

\section{Montgomery County.}

The fact of Robert Coleman's connection with this forge is its chief interest. His first venture for himself, he came here shortly after his marriage in 1773 , when the trouble with England was brewing. Mr. Coleman's grandson has a document of rare interest illustrative of Revolutionary experiences at Salford Forge. It is endorsed "Robert Coleman's memorial, presented August 26th I776, asking permission for his clerk and three forgemen to be exempted from marching with army to Amboy"; it sets forth that he had rented a forge for three years at a rental of two hundred a year, the lease of which would expire in three months; and that the "principal part" of his workmen were Associators, who, if obliged to march with the militia, would cause him great loss and entirely prevent him from working up his stock in hand. The request of Mr. Coleman was granted the same day by the Council of Safety to whom it was addressed. While at this forge he manufactured chain bars, which were designed to span the Delaware for the defense of Philadelphia against the approach of the enemy's fleet. ${ }^{1}$

${ }^{1}$ Ironmaking in Pennsylvania, by James Swank, p. 27. 
SEQUENCE OF FRANKLIN FIREPLACES. 

$$
\text { . }
$$ 



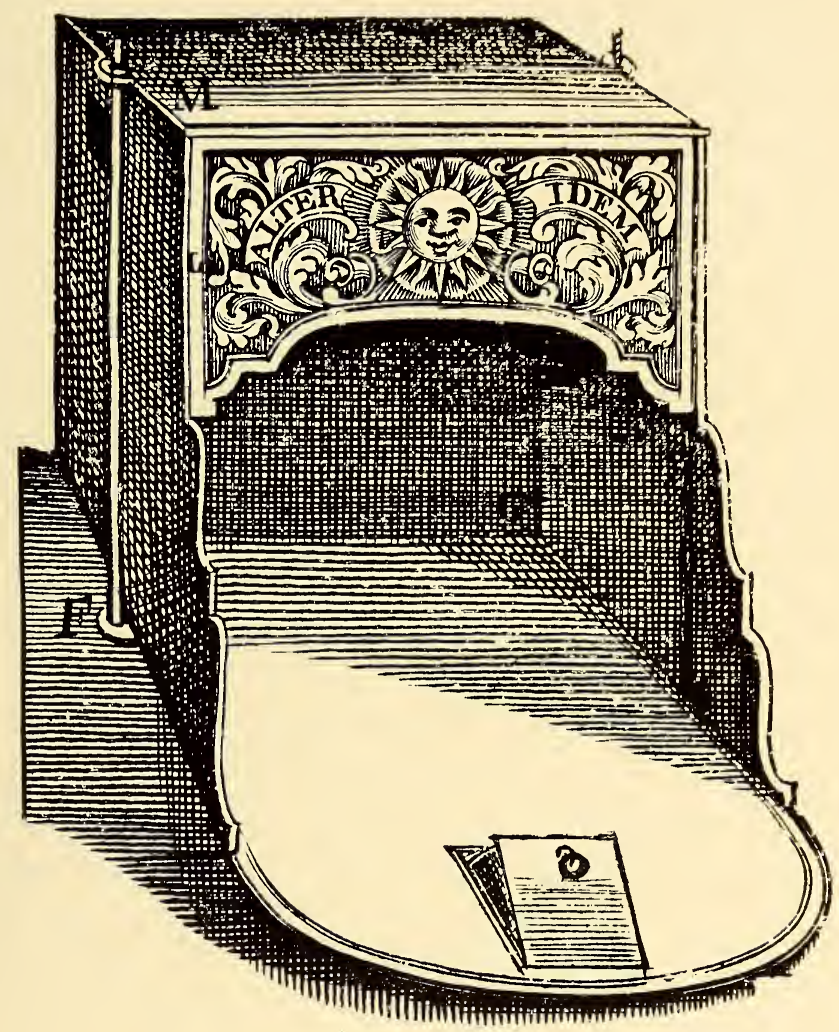

Franklin's First Model.

From "An account of the new invented Pennsylvanian Fireplace. Philadelphia, Printed and sold by Benjamin Franklin, I 744." 



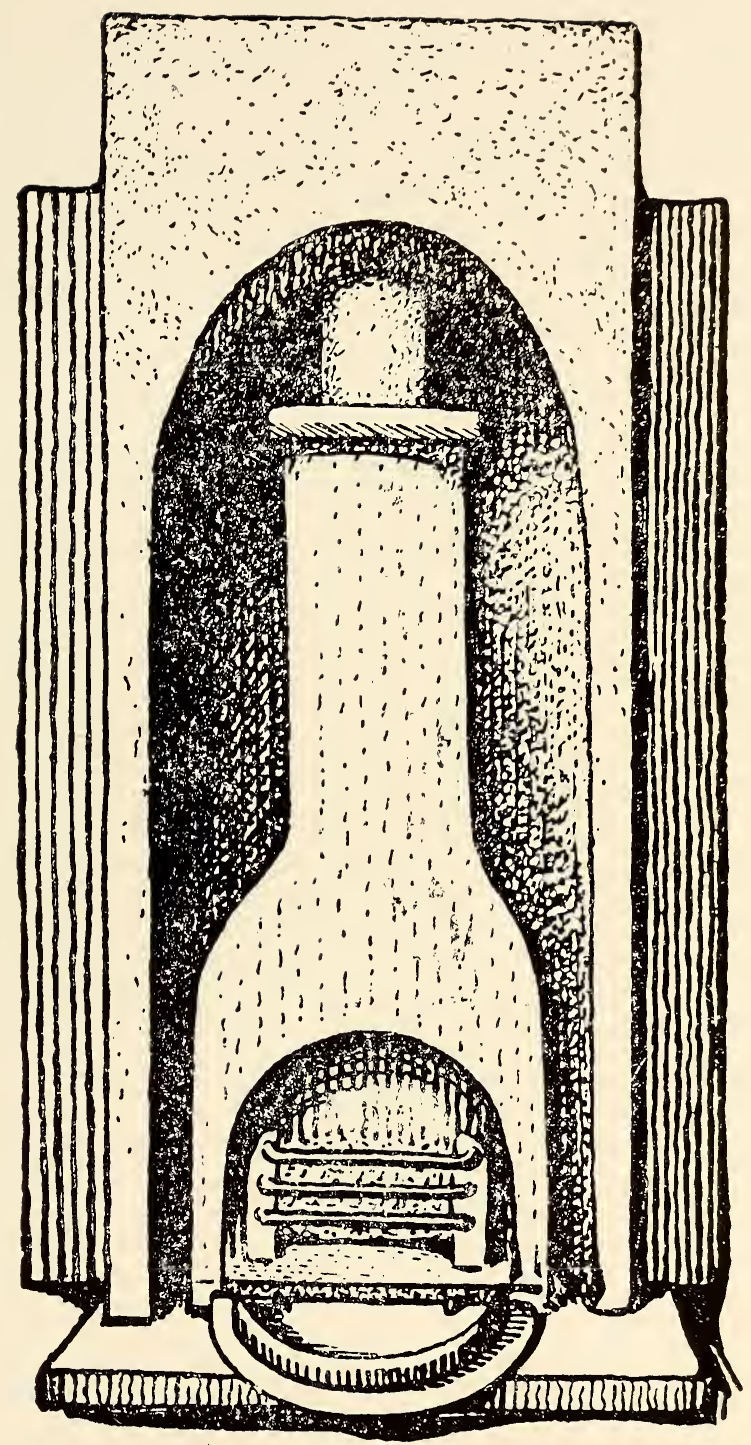

A Franklin Model. The original in possession of the American Philosophical Society. 



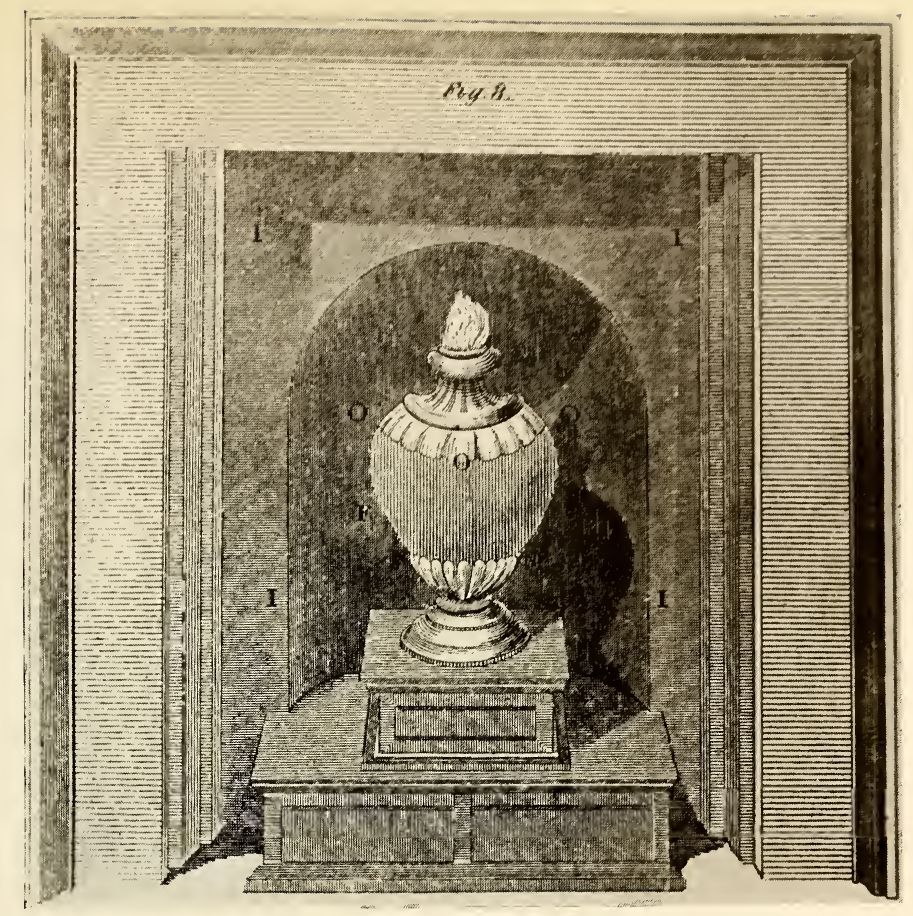

Franklin's Model for Stove in the form of an Urn. Full description in

"Transactions of the American Philosophical Society," Vol. II, I 786.

Judge Jasper Yeates, writing from Lancaster, December 26, 1777 , to Col. Burd at Tinian, says: "Hon'd Sir, . . . I also enclose you a copy of verses on the celebrated urn of Doctor Franklin. They are, in my opinion, exceedingly well wrote and contain the true Attic salt. ${ }^{1}$

"Inscription on a curious stove in the form of an urn, contrived in such a manner as to make the flame descend instead of rising from the fire; invented by Dr. Franklin.

"Like a Newton sublimely he soared To a summit before unattained,

New regions of science explored And the palm of philosophy gained.

"With a spark which he caught from the skies He displayed an unparalleled wonder, And we saw with delight and surprise That his rod could secure us from thunder.

" Oh! had he been wise to pursue The track for his talents designed What a tribute of praise had been due To the teacher and friend of mankind.

"But to covet political fame Was in him a degrading ambition. The spark that from Lucifer came Enkindled the blaze of sedition.

"Let candor then writs on his urn Here lies the renownèd inventor Whose flame to the skies ought to burn But, inverted, descends to the centre."1

These verses are supposed to have been written by Hannah Griffiths, granddaughter of the first Isaac Norris.

1 Shippen Papers, by Thomas Balch, p. 264.

1 Life and Writings of Benjamin Franklin, by Albert Henry Smyth. I. p. I 30 . 



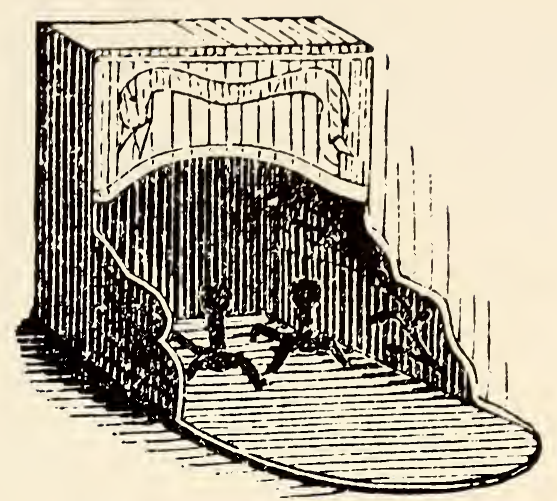

Fireplace of primitive design. From Lossing's Field Book of the Revolution.

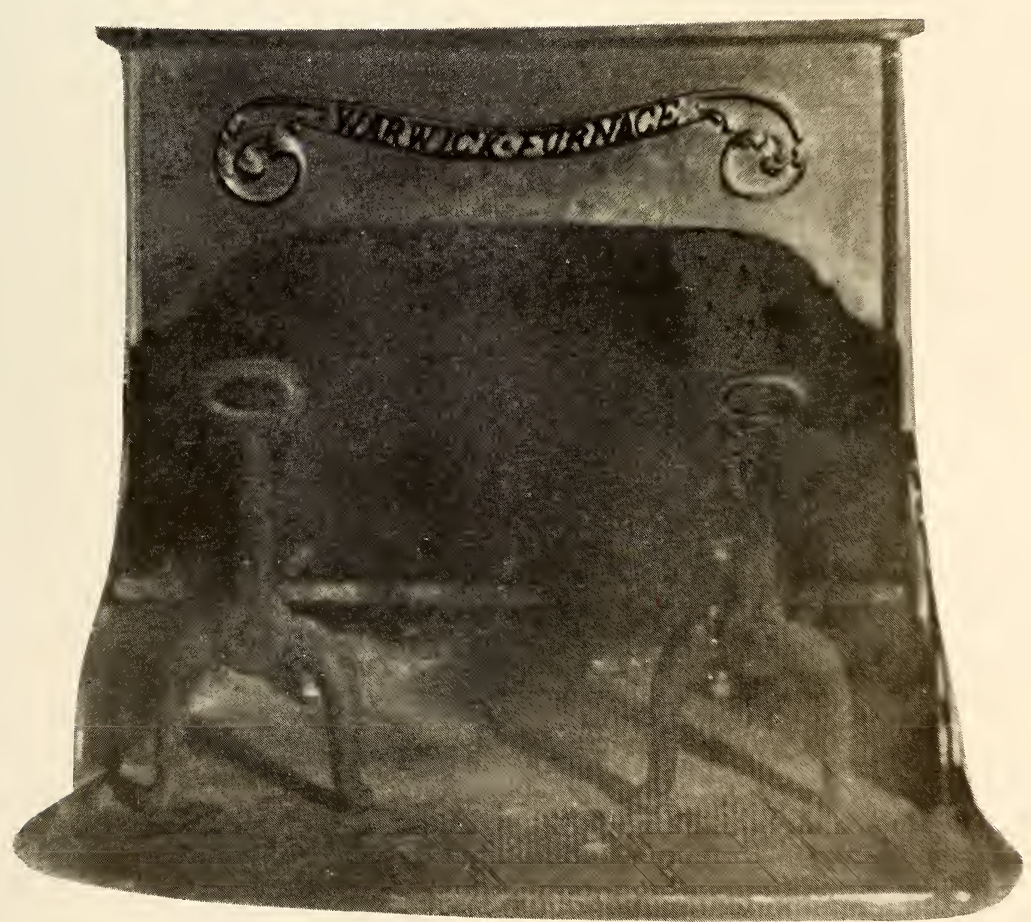

Fireplace in Mansion, Pine Forge, owned by Mrs. Darid Rutter. Made at Warwick Furnace, probably from earliest design. 



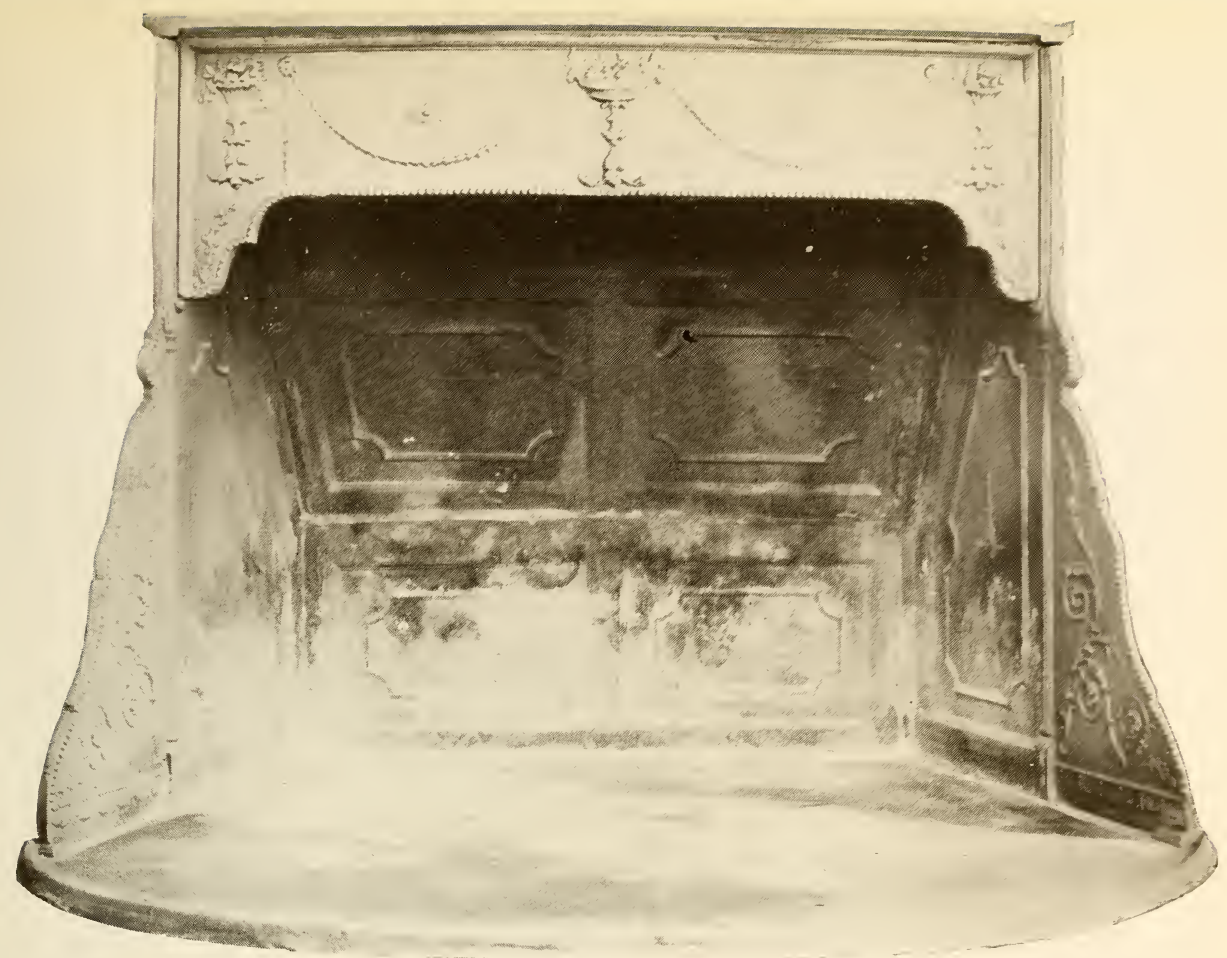

Fireplace at Stenton, the home of James Logan. 1750 to 1760.

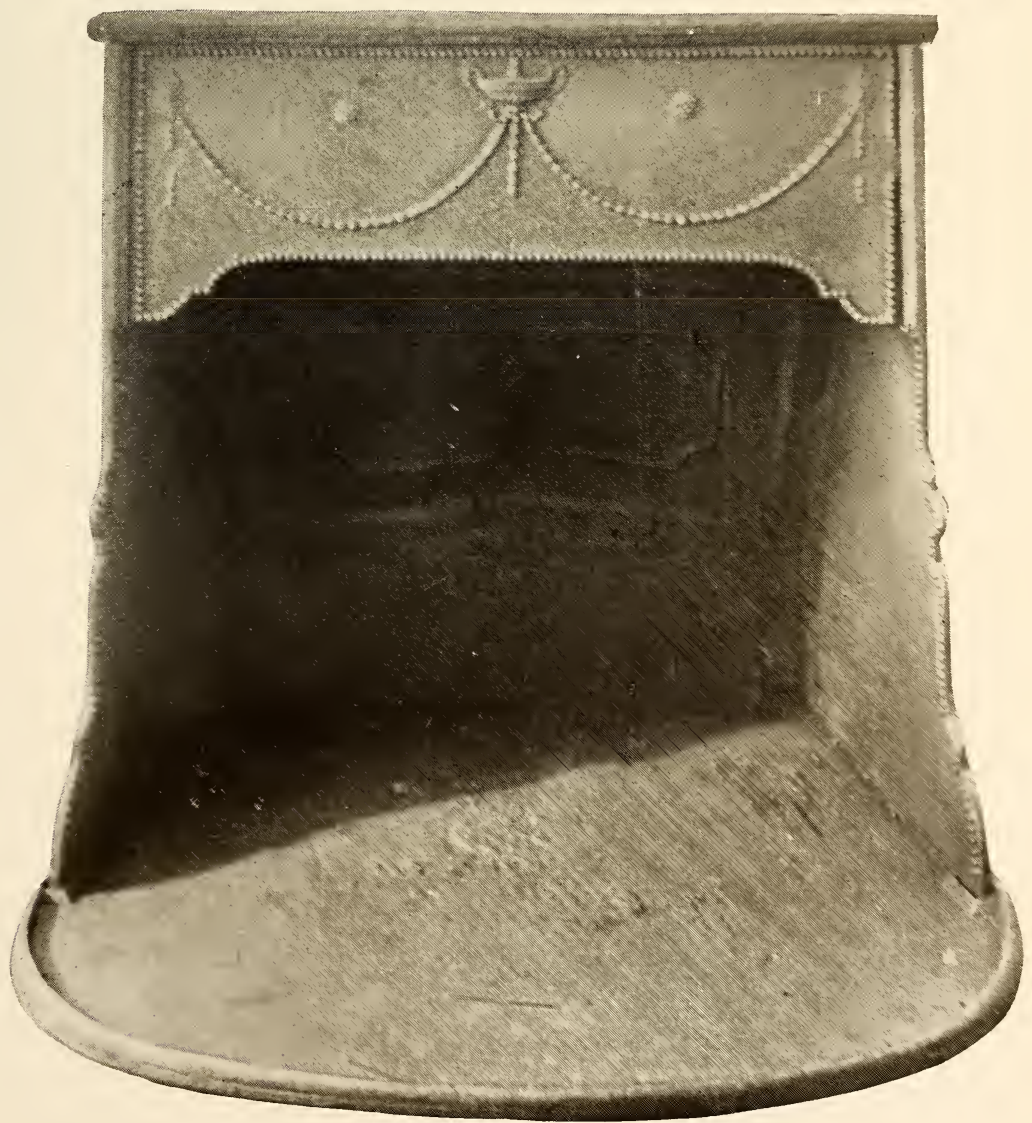

Fireplace. About I750. Harriton. 



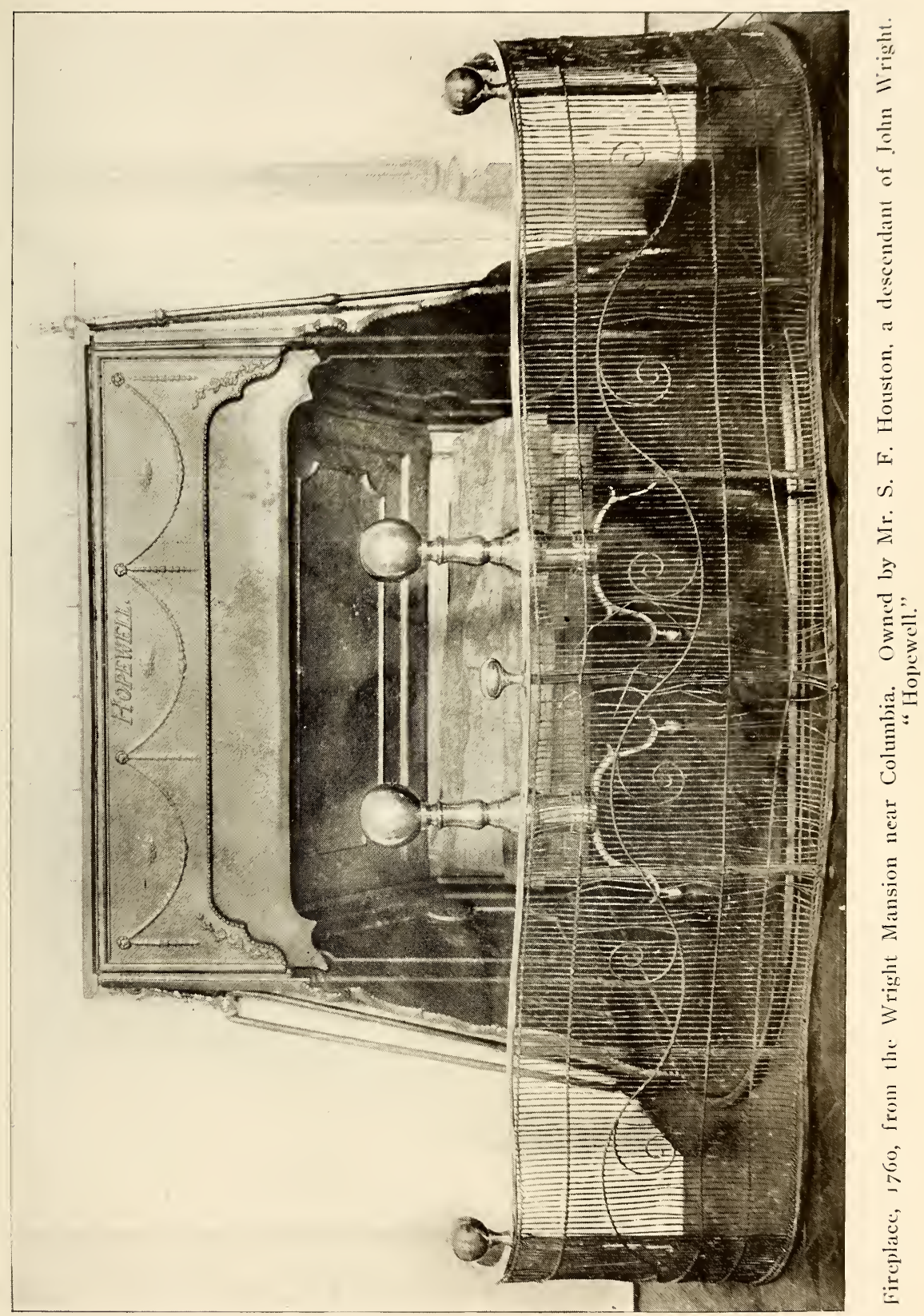





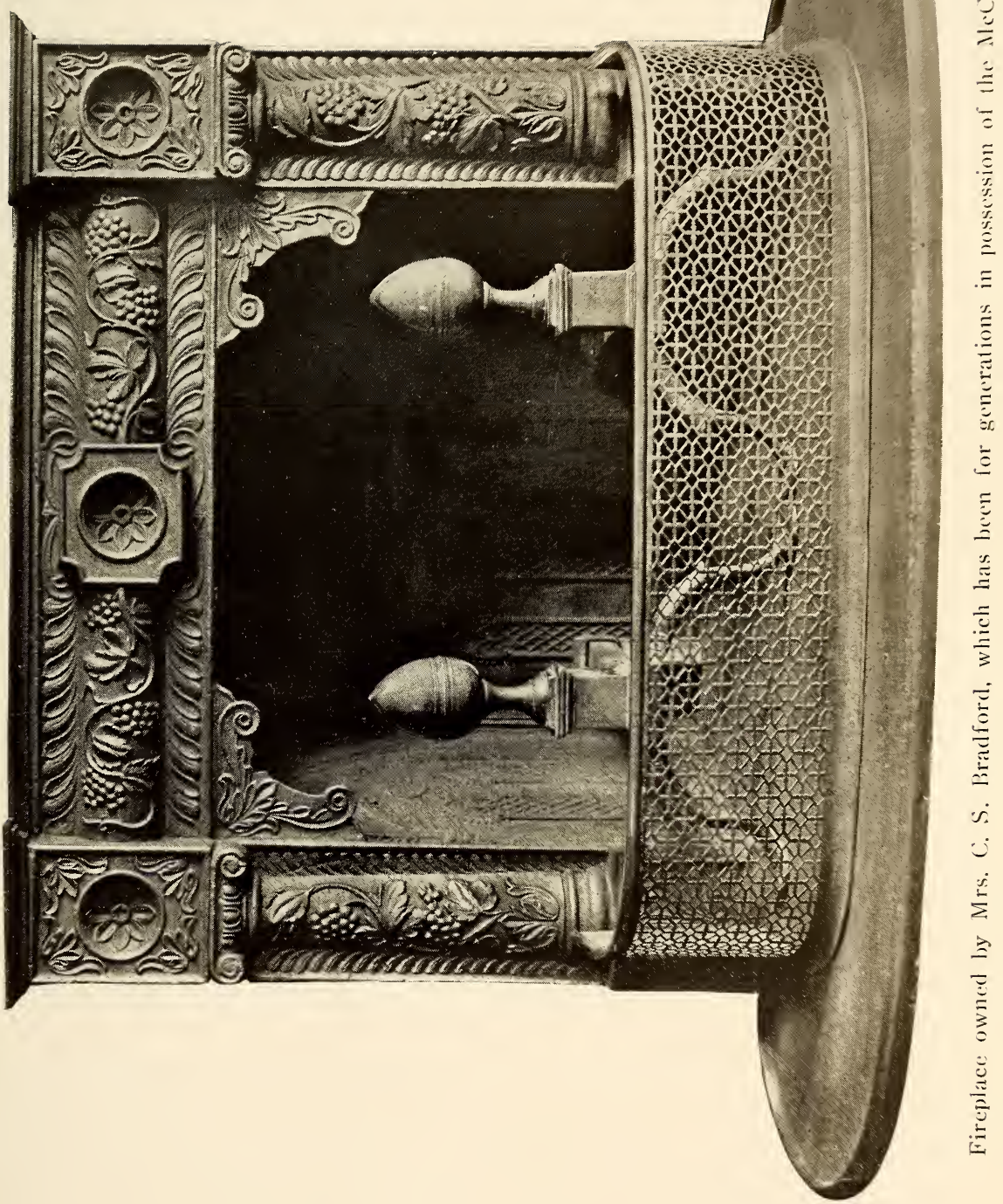





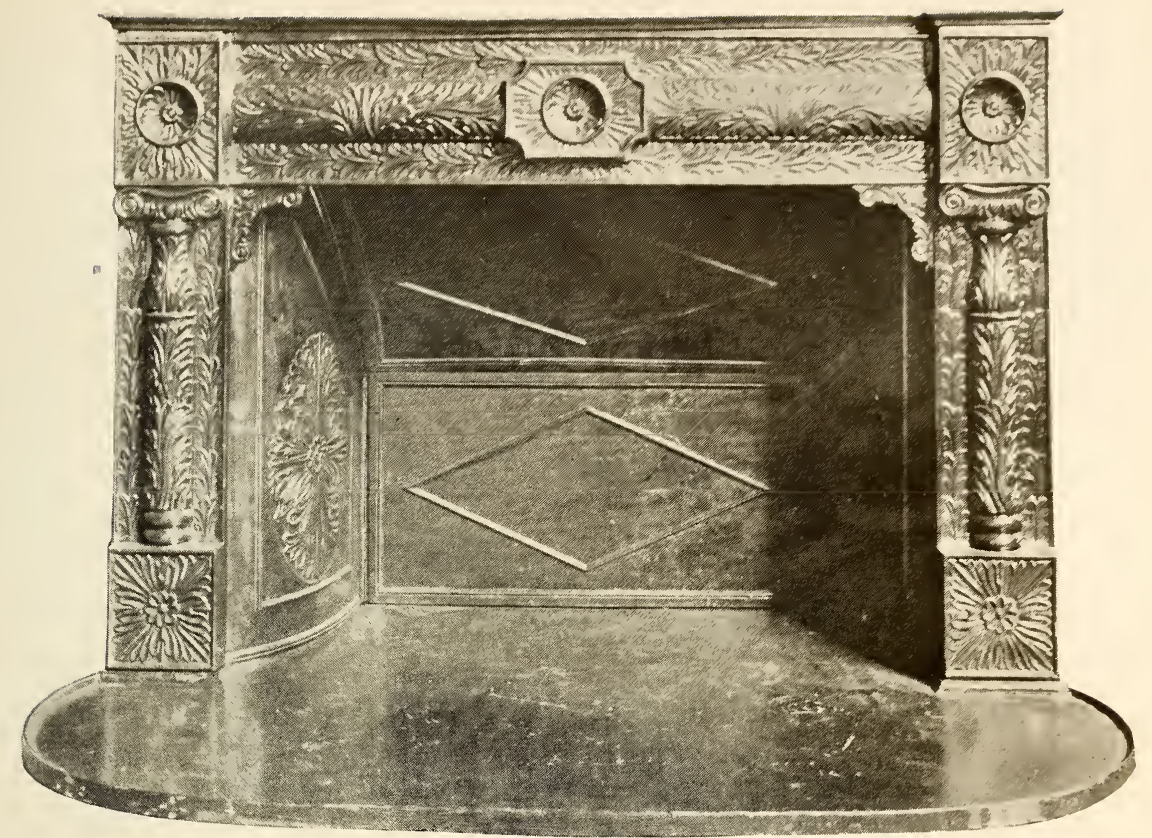

Fireplace from home of Susanna Wright, Wright's Ferry, i760. Owned by Mr. S. F. Houston.

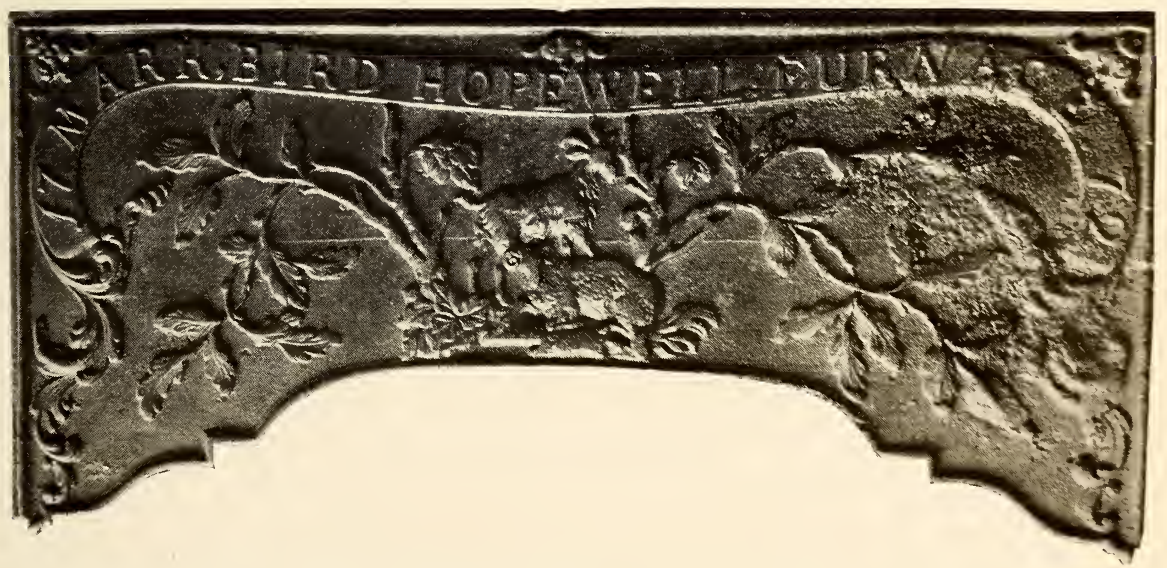

Fireplace Top, iz72. Hopewell Furnace Berks County. Owned by the Historical Society of Pennsyliania. 



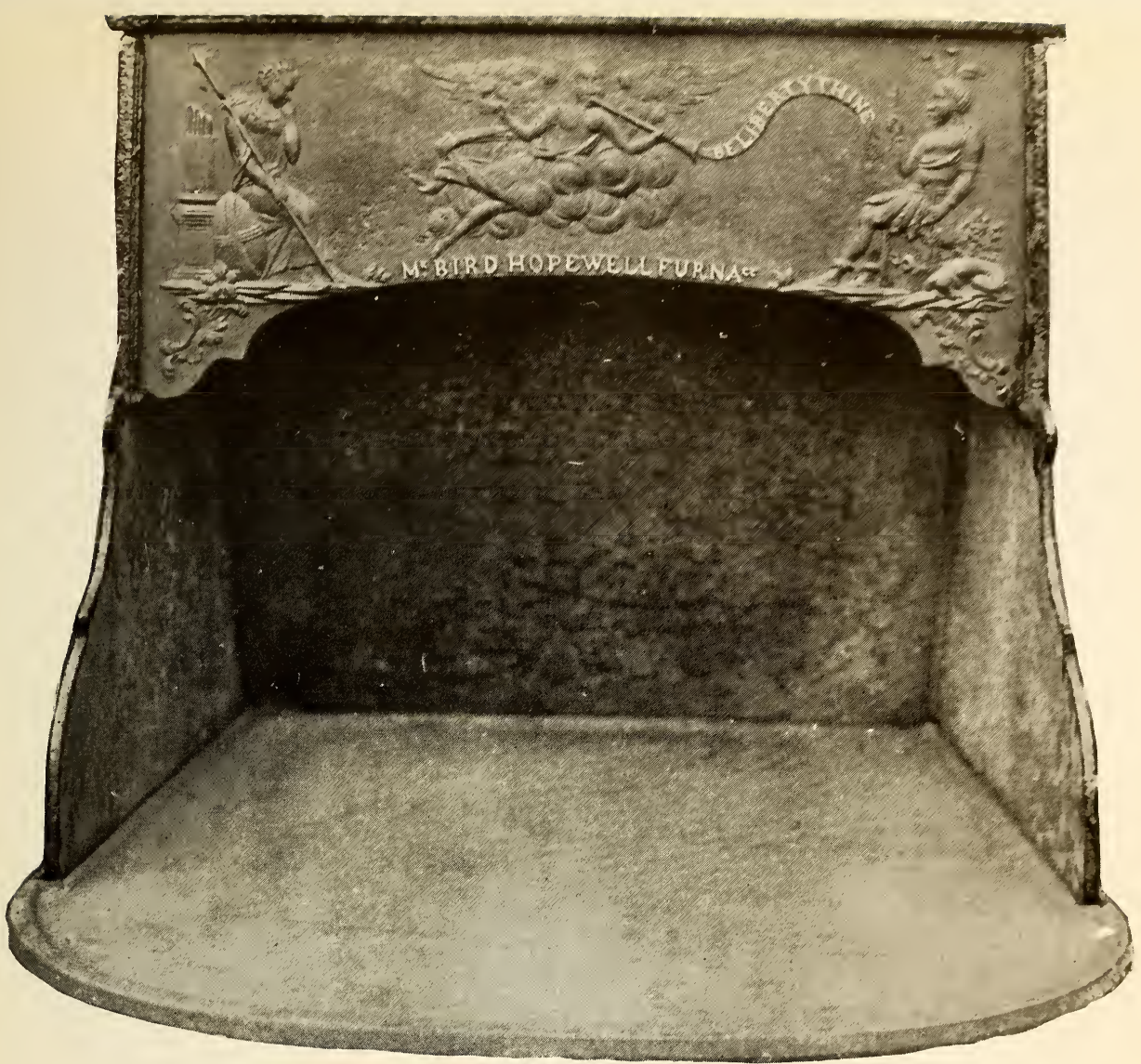

Fireplace, Hopewell Furnace, showing style of design after i 776 .

The motto "Be Liberty Thine" on a fireplace, fixes its date as after the Revolution.

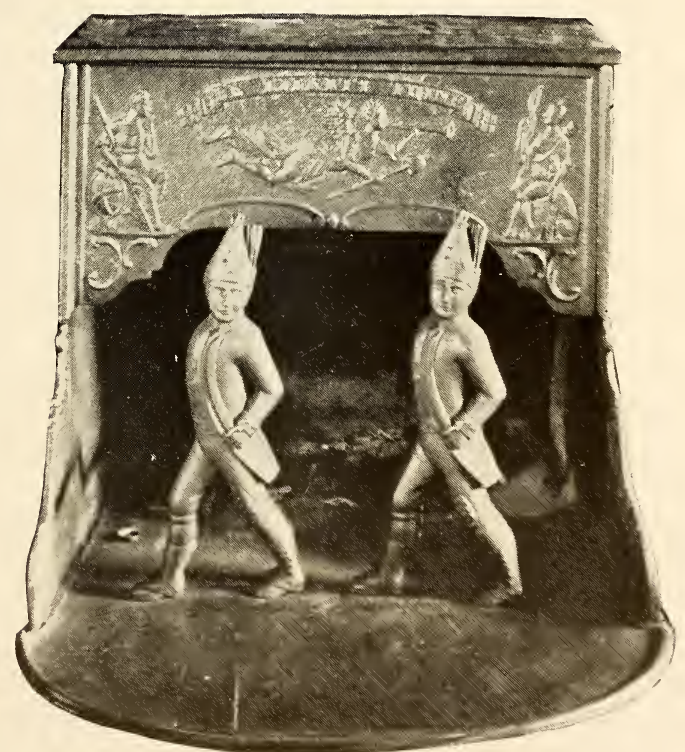

Fireplace owned by Mr. A. J. Steinman, Lancaster. "Be Liberty Thine." Hessian andirons were much in use at the time. 



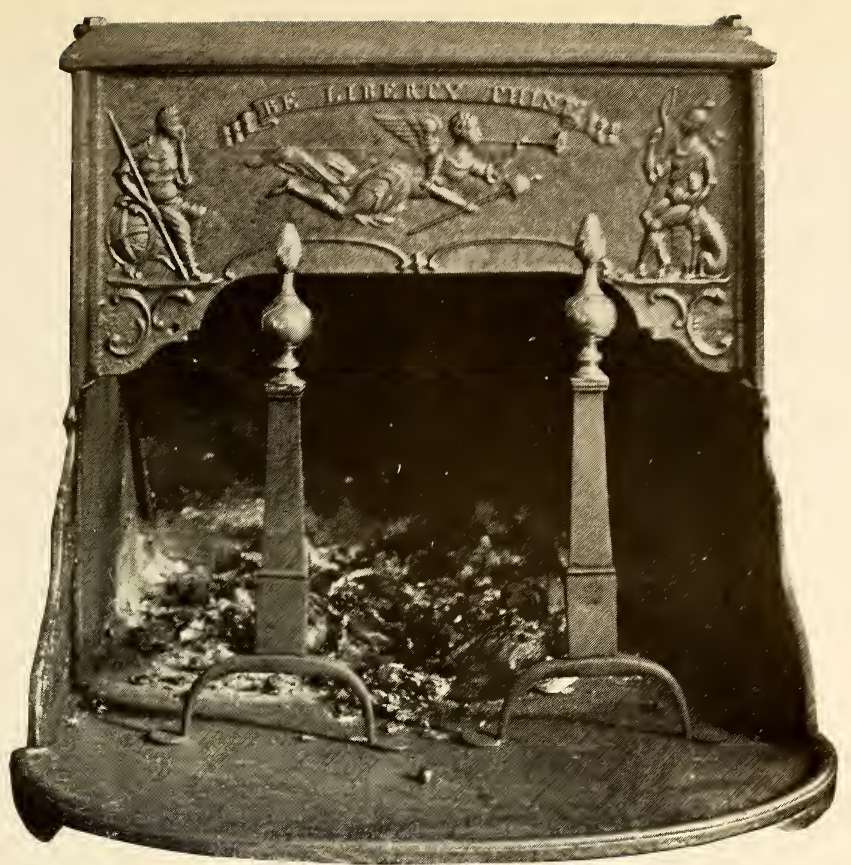

Fireplace owned by Dr. William T. Sharpless, West Chester. Made shortly after the Revolution.

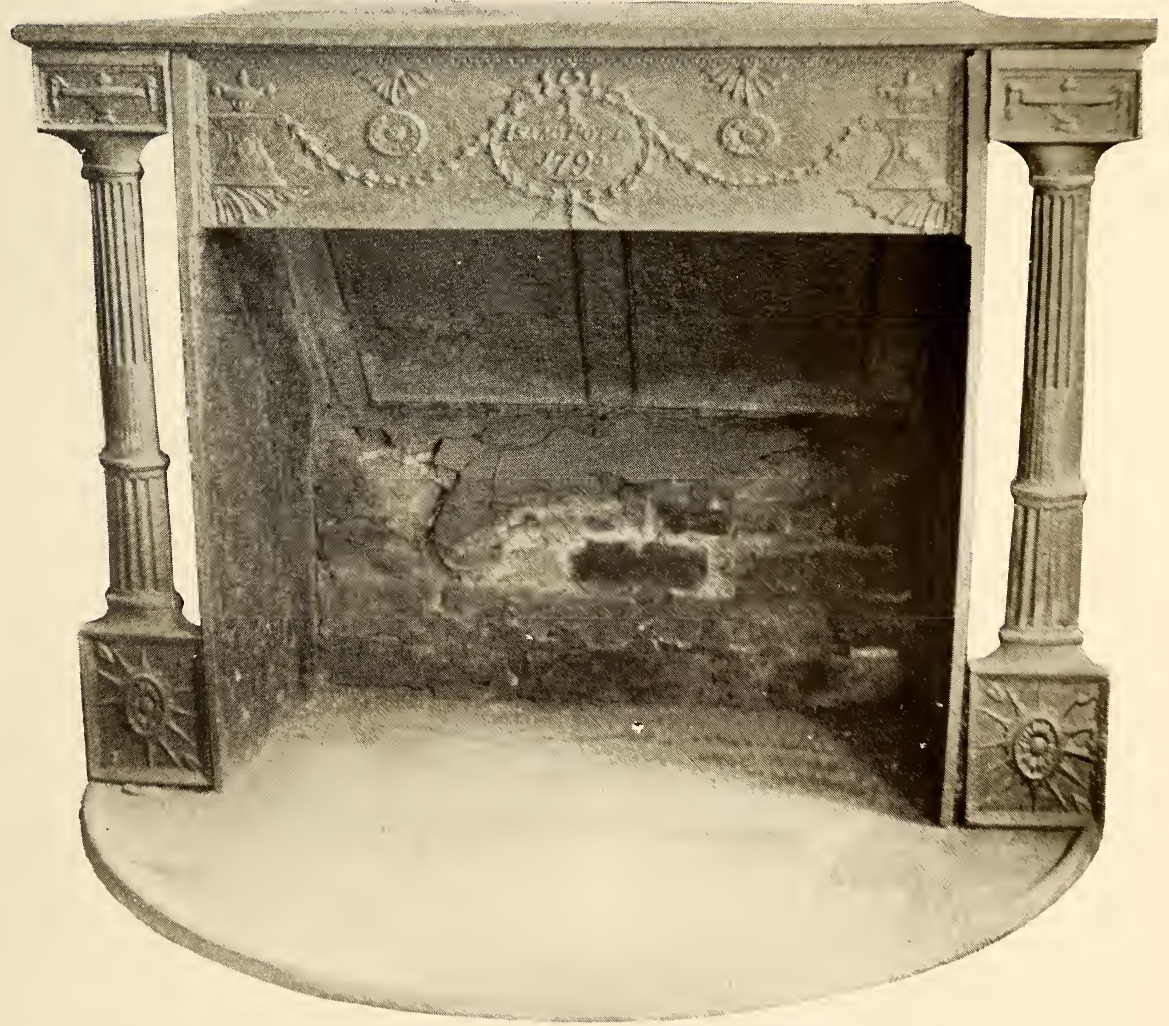

Fireplace in residence of Mr. J. H. Osborne, Summerseat, Morrisville. once Washington's Headquarters. "Isaac Potts, 179.5." 



\section{GENERAL INDEX}

A

Abbington Furnace, 42

Abbington Iron Works, 42

Allen, Chief Justice William, 45

Allen, William, warrant to, for

5000 acres of land, 84

Amboy, march of Army to, 188

American flint glass, 125

American Philosophical Society, 19

Amherst, Sir Jeffrey, 166

Ammunition for Army, 173, 174, 177

Anchor Forge, 147

Andover Iron Works, 44

André, Major, 93

Antes, Colonel Frederick, 146

Anthracite coal, first shipment of, 173

Arks for shipping coal, 52, 173

Armor, Thomas, 166

Armory at Carlisle, 173

Armour, Martha, 101

Armstrong, Dr. James, 166

Armstrong, Brigadier General John, $166,167,172,173$

Army supplies during Revolution, 112

Art in early iron work, 9, 127, 178, 179

Arthur, John, 186

Artificers, company of, 173

Artificers, Franklin's bequest to, 71

Ashleman, Benjamin, 137

Assembly of Pennsylvania, 68, 97, 162

Associators, 162, 188

Attwood, Capt., 23, 64

Attwood, William, 15, 22, 23, 64
B

Backhouse, Mary, 57

Backhouse, Richard, 48, 56, 57

Bailey family, 63

Ball, Wm., 72

Bar iron, duty on, in England, 98

Barde, John Louis, 77

Barnard, Nicholas, 140

Barr, John, 121

Barr, Thomas B., 161

Barracks at Philadelphia, 157

Bartram, Alexander, 127

Battalion of Associators for Lancaster Co., 162

Bees, quilting and spelling, 184

Bell at Valley Forge, 94

Benezet, Daniel, 117, 127, 128, 130

Bennett, William, 177

Berks County, forges and furnaces in, $11,20,58,62,75,76,79,111$, $115,118,133,152,154,158,170$, 178

Berkshire Furnace, 76, 152 . See also Roxborough Furnace.

Bernwick, Jas., 140

Bertolet, Samuel, 146

Bezalion, Peter, 4

Biblical scenes as decoration of stoves, 8

Biddle, Edward, 78

Biddle, Owen, 153

Bird, Col., 86

Bird, James, 157

Bird, Maria, 157

Bird, Lieut.-Col. Mark, 76, 77, 78, $80,81,152,153,154,156,157$, 158

Bird, Mr., a prisoner, 168 
Bird, William, 64, 76, 79, 80, 82, $152,154,157$

Bird Iron Works, 77

Bird and Patton, 82

Birdsboro and Hopewell estate, 158

Birdsboro Forges, 76, 82, 155. See also Hay Creek Forges.

Birdsboro Militia, 77

Blackburn, John, 166

Blast furnace, first west of Susquehanna, 160

Blister steel, 18

Blonde, the, ship of war, 168

Boats, Durham, 51, 52

Boiling Springs, 172, 175

Boom, Geo., 23

Boon, Boone, G., 15, 22, 31, 64

Boone, George, 64

Booth, R., 50

Boyer, John, 81

Bradford, Andrew, printer, 45

Brandywine, the, battle of, 34,73 , 93, 155, 174

Brandywine, retreat from, 95

Branson, Nathaniel, 18

Branson, Rebecca, 101

Branson, William, $16,17,18,32$, $33,69,70,100,101$

Branz's works, 18

Brenner, Garrett, 115

Brewing, " art and mistery of," 58

Brickersville, Lutheran Church in, 120

Brien, Edward, 142

Brinton, John, 169

British, capture of cannon by, 174

Brockden, Charles, 21

Brooke, Mrs. Edward, 158

Brooke, E. \& G., iron Works of, 78

Brooke, Matthew, 77, 158

Brooke, Thomas, 158

Brooks, Mathias, 72

Brown, Alex., 50

Brown, Richard, 166
Buckley, Daniel, 158

Buckley, Mr. \& Mrs., 104

Bucks County, forges and furnaces in, 43,51

Burd, Edward, 164

Byberry, plating forge in, 18

C

Cadwallader, Thomas, 166

Caldwell, David, 159

Camp Pottsgrove, memorial tablet at, 146

Canadian Campaign, 168

Canals for transportation, 182

Candles, moulding of, 185

Cannon, burial of, at Hopewell and Warwick, 155

Cannon, burial of, at Valley Forge, 94

Cannon, casting of, $73,86,118,153$, 155, 169

Cannon, wrought iron, 174

Cannon Hill, 124, 130

Capital invested in forges, 20, 110

Carbon County, 135

Carlisle, 161, 166, 181

Carlisle, social life of, 186, 187

Carlisle Barracks, 173

Carlisle Iron Works, 172,175

Carmichael, Catherine M., 103, 104

Carmichael, Rev. John, 103

Catalan forge, $6,12,16,82$

Chain bars, manufacture of, 188 .

Chalice, silver, presented by Queen Anne, 13

Chapman, John, 44

Charcoal burning, 6, 8, 133

Charcoal, charring and carting of, 110

Charcoal furnaces, abandonment of, 89,110

Charcoal furnaces, construction of, 6 
Charcoal furnaces, consumption of wood in, 23, 156

Charcoal furnace, working of, 181

Charles River, the Falls of, 51

Charming Forge, 115, 153, 175

Chester County, 16, 25, 67, 69, 76, 90, 96, 97, 118, 151

Chew, Benjamin, 166

Chiswell, Mr., 98

Christ Church, Philadelphia, 40, 164

Christiana Creek, 38, 42

Church, Baron Stiegel Memorial, 125

Church, Lutheran, at Brickersville, 120

Church, Lutheran, at Manheim, 124

Church, St. Gabriel's at Morlattan, 31,76

Church, St. James', Lancaster, 132, 163

Church, Trinity, at Oxford, 12

Churches, Hessian prisoners in, 85

Churchtown, 68

City Council of Philadelphia, 40

Clark, John, 140

Clawson's Tavern, 54

Claypoole, James, 44

Clymer Iron Works, 176

Codorus Creek, 151, 177

Codorus Forge ANd Furnace, 177

"Cole Book," 79, 82

Colebrookdale Furnace, 20, 30

Coleman, Robert, 1, 82, 86, 87, 119, $126,129,130,159$

Coleman, Robert, at Quittapahilla Forge, 135, 141, 142

Coleman, Robert, at Salford Forge, 188

Coleman, Robert, entertainment of Washington by, 131

Coleman, Sarah, 132

Colonial furnaces, casting in, 8

Committee of Safety for Pennsylvania, 162
Committee of Safety of Philadelphia, 156

Company, a, store in provincial times, 108, 183, 184

Concord Meeting, 25

Conewago Settlement, 160

Conestoga Creek, forges on, 102, 159

Conestoga, Settlement, attack on, 138

Conestoga Turnpike, 155

Conestoga Valley, 67

Connor, Thomas, 92

Conodoguinet Creek, 167

Continental Army, accoutrements and arms for, 156, 157

Continental Army at Camp Pottsgrove, 146

Continental Congress, 61

Continental Congress, delegates to, 163

Continental Congress, establishment of Armory by, 173

Constitutional Convention, 162

Cookson, Thomas, deputy surveyor, 164, 165

Copper mine, old, near Lancaster, 5

Cornwall Furnace, 83, 85

Cornwall Furnace, indenture concerning, 85

Cornwall Mines, product from, 89

Counties, lower, 36, 42

Court House at Philadelphia, 14

COVEntry Forge, 16, 25-27, 33, 34

Coventry Hall, 19, 29, 62

Cox, Dr., 2

Cresheim Creek, 12

Crosby John, 97

Crum Creek, 96

Crum Creek Forge, 97

Cryble, Saml., 72

Cumberland County, 171, 172, 181

Cumberland County, cannon made in, 174

Danner, George H., 126 
Danner, G. H., museum of, 123

Danner, Michael, 166

Darby, Abraham, 21

David Jones Furnace, 67

Davies, Gabriel, 159

Davies, Margaretta, 159

Decorations on stoves, $8,49,50,121$, 161,173

Delaplank, Frederick, 178

Delaware, discovery of iron ore in, 38

Delaware, Welsh, settlers in, 42

Delaware County, iron works in, 96 , 97

Delaware Indians, treaty with, 14

Delaware River, chain bars to span, 188

Dewees, Col. William, Sheriff of Philadelphia, 92

Dickinson, John, 126, 128, 129

Dickinson, Jonathan, 11, 30

Dicks' Bloomary Forge, 97, 151

Dicks, Peter, 97, 151

Diggs, Anne, 36, 37

Dillwyn, George, 149

Docwra, Mr., 2

Doughten, Stephen, 80

Doyle, Lawrence, 81

Drinker, H., 50

Dunning, William, cannon made by, 174

Durham boats, $51,52,54$

Durham firebacks, 48, 49, 61

Durham Furnace, 43, 60

Durham, Robert, 51

Dutch settlers, 2

E

Eckert, Valentine, 178

Edgemont Road, 74

Ege, Bernhard, 118

Ege, George, 76, 81, 117, 118, 141, $142,152,153,159,169,171$
Ege, George Michael, 122

Ege, Michael, 118, 171, 175, 186

Ege, Rebecca, 159

Egle, Dr., 41

Election times in iron regions, 107

Elizabeth Furnace, 119, 121, 122, 159

Ellis, Robert, 45, 47

Ellis, Rowland, 61

Emlen, Samuel, 149

England, first furnace in, for casting pots and kettles, 21

Etter, Gerard, 135

Evan-Ap-Evan, 90

Evans, Governor, as mine operator, 4

Evans, Lewis, 91

Evans, Stephen, 91

Executive Council of Pennsylvania, 118,157

Export of iron, restriction of, 11

Eykelburger, Martin, 166

F

Fager, Col., J. M., 94

Fagleysville, 146

Falls of Delaware, 51

Farmer, Edward, 64

Fatlands Ford, 93

Fegan, John, 79, 80

Fergusson, Mrs., 38

Ferree, John, 128

ffream, Edw'd, 23

ffrench, Nath., 15, 22, 23, 64

Firebacks, early, 48, 49, 61, 172

Firebacks, moulding of, 10

Fireplaces, Sequence of, 189

Fisher, Hannah, 150

Fitzwater, George, 45

Flint glass, manufacture of, 125

Flower, Enoch, 58

Flower, Samuel, 18, 101

Foley, James, 81

Footman, Richard, 141 
Ford, Nathaniel, 16

Forge Tract, 40

Foul Rift, 51

Foulke, Hugh, 37

Fox, John, 139, 140

Frame, Richard, 5

Francis, John Tench, 70

Franklin, Benjamin, 24, 70, 71, 130

Franklin fireplaces, 73

Franklin stoves, 70,72

French, the, early mining ventures of, 5

French Creek, 13, 16, 19, 25, 26, $27,28,29,34,69,87$

French Creek, Cannon imbedded in, 73

French Creek Iron Works, 154

French, Nathaniel, 64

Fricker, Mr., of Reading, 153

Fulton, James, 137, 140, 141

Furnace Creek, 160, 176, 178

Furnace Run, 130, 136

\section{G}

Galloway, Joseph, 55, 57

Geddes, Henry, 165

Geddes, Jane, 165

George the Third, commission from, 165

German iron workers, artistic wares of, $9,161,178,179$

German settlers, 49

Germantown, 65, 143, 144

Giger, John, 169, 171

Giles, Jacob, of Baltimore, 85

Glasgow Forge, 39. See also McCALL's Forge,

Glass, Martin, 145

Glassware, Stiegel, 126

Glen Mills, 96

Gold in Delaware, 42

Golden Lion, 18

Gordon, Patrick (Governor of Province), $14,30,59$
Government, shot and shell for, 130

Governor's Council, "Remonstrance " to, 147

Grace, Robert, 18, 19, 70, 71, 72, 79

Graeff, Sebastian, 111

Graeme, Thomas, physician, 37

Graham, Alex., 140

Graves, Robt., 140

Gray, Colonel, 93

Great Spring, 152, 153

Great Valley, 91

Green Lane Forge, 66

Grey, T., 4

Griffith, Robert, 20

Growden, Grace, 55, 57

Growden, Lawrence, 55, 57, 166

Grubb, Col. Curtis, $81,82,85,86$, 117,153

Grubb, Henry Bates, 87

Grubb, John, 84

Grubb, Peter, 1, 41, 82, 84, 85

Grubb, Peter, Jr., 86

Grubb, Peter, 3rd, 86

Grubb, Samuel, 84

Grubb's Iron Works, 83

Grubb's Landing, 84

Guest, Phoebe, 59

GulF FoRge, 180

Guns, boring of, 173

\section{$\mathrm{H}$}

Hackett, John, 47

Haiman, Widow, 137

Haldane, James, 140

Hall, John, 18

Hall, Joseph, 18

Hamilton, Charles, 177

Hamilton, Hance, 166

Hamilton, James, deputy Gov. of

Pennsylvania, 57, 165, 166

Hammer Creek, 82, 87, 159

Hanover, 151

Harris, Robert, 140

Harrison, Hannah, 61 
Harrison, Richard, 61

Harriton, Bryn Mawr, 61

Haupt, Abraham, 51

Hay Creek or Birdsboro Forges, 76, 82

Hay, Sheriff, 138

Hazlewood, Wm., 140

Hebron, Hessian prisoners at, 85

Heidelberg, 76, 117, 152

HeREFoRd FurNaCE, 133

Herlinger, P., 152

Hessian prisoners, 85, 118, 130

Hessian prisoners, channel cutting by, 118

Hibbert, John, 16

Hill, Richard, 29, 150

Hillegas, Michael, 140, 141, 142

Hockley, James, 40, 91

Hockley, Richard, 18, 101

Hollow ware, casting of, 8, 172

Holmes, John, 166

Holstein, Matthias, 77

Hölz, Anna Catherine, 122

Hölz, Elizabeth, 121

Hoopes, Adam, 139

Hopewell Creek, 156

Hopewell Forge, Grubb's, 82, 87

Hopewell FurNace, 154

Hopkins, John, 45

Howe, Sir William, at Valley Forge, 93, 95

Howe, Sir William, march of, to

Philadelphia, 73, 94, 128, 155

Huber, Elizabeth, 119, 121

Huber, Jacob, 159

Huber, John Jacob, 119, 121

Hughes, Gabriel, 81

Huling, John, 79

Hulings, Brigetta, 76

Hulings, Magdalena, wedding of, 77

Hulings, Marcus, 76, 77

Hulings, Marcus, Jr., 62

Hunsecker, John, grant of land from the Penns, 160

\section{I}

Indentured servants, desertion and enlistment of, 70

Indian barter, 52

Indian character, Penn's estimate of, 13

Indian Commissioner at Fort Pitt, 162

Indian Council at Philadelphia, 14

Indian pottery, 44

Indian trails as highroads for grain, 110

Indian Treaty, 14, 45

Indian woodcraft, 51

Indians as mine workers, 5

Indians at Manatawny, 40

Indians employed in forges, 23

Indians, hostility of, $30,31,47$

Indians, lands seated by, 28

Indians, murder of, $31,137,138$

Intermarriages in iron-making world, 63, 75

Irish, Nathaniel, 47

Iron, export of, in 1717, 11

Iron, importation of, 127

Iron industry in 1789, 75

Iron in Province, early mention of, 5

Iron, manufacture of, primitive processes, 6

Iron masters, patriarchal life under, 183

Iron ore in Pennsylvania, early knowledge of, 43

Iron works, early, statistics concerning, 10

Iron workers, skilled, brought to America, 26

Iron Hill, 38, 42

Iron Stone Creek, 20, 24

Irvine, Col. James, 68

Isaac, Lazarus, 126 
L

Jacobs, Cyrus, 159

James, James, 42

James, Mrs., the historian, 18, 22, 30,75

James, Samuel, 42

Jenkins, David, 99, 101, 102, 109

Jenkins, John, 99, 102

Jenkins, Hon. Robert, 102, 103, 106, 109

Jenkins, William, 102

Johnson, George B., 99

Jones, Caleb, 67

Jones, John, 62, 67

Jones, Lieut.-Col. Jonathan, 67

Jones, Keim \& Company, 179

Jones, Mary, 58

Jones's mine holes, 67

Joy, Capt. Dan'l, 86

Juto, Wm., 140

\section{K}

Kalbach, Adam, 81

Kalm, Peter, 96

Keim, D. M., 179

Keim, George May, 179

Keith, Alexander Henry, 36

Keith, George, 12

Keith, Sir William, Governor of Pennsylvania, 36, 37

Keith, Sir William, furnace of, 36

Kerlin. See Keurlis.

Keurlis, Martha, 143

Keurlis, Peter, 144

Kidd, John, 140

Killingworth, Rev. Thomas, 12

Kinsey, John, attorney, 70

Kirkpatrick, David, 166

Krebs, Joseph, 81

KURTZ's Iron Works, 41

Laman, Rev. John B., 105

Lake Superior iron ore, 89

Lancaster, road from Philadelphia to, 154

Lancaster County, 41, 67, 82, 85, 98, 118, 119, 135, 136, 158

Lancaster Co., first Battalion of Associators of, 162

Land grant to soldiers, 130

Langhorne, Jeremiah, 44

Lardner, Lynford, 18, 101, 166

Lawler, Ann, 160

Lawler, Mary, of Lancaster, 160

Leacock, Jno., 15, 22, 64

Lebanon County, forges and furnaces in, 82, 89, 135

Lenan, Jacob, 80

Lenni Lenape Indians, habits and traits of, 13, 14

Lesher, Jacob, 113

Lesher, John, 111, 113, 153, 176

Le Tort, James, 4

Leutze, E., 54

Lewis, James, 20

Leycock, Jno., 23

Lincoln, Abram, 80

Lincoln, John, 80

Lincoln, Mordecai, 99

Lincoln, President, 99

Lindley, Thomas, 45

Logan, James, 1, 29, 45, 46, 49, 57

Logan, James, as Secretary of the Province, 2, 3

Logan, William, 57, 166

Longhead, Jas., 140

Longstreth, Daniel, 140

Lower Counties, 36, 42

Lowden, Hugh, 70

Lower, Christian, 170

Lower Forge, 80

Lower Hopewell Forge, 159

Lancaster, old copper mine near, 5 Lower Providence, 57 
M

Malcolm, John, 139, 140, 141

Manatawny Creek, 11, 15, 20, 39, $58,62,111,143,144,145,158,170$

Manheim, 117, 123, 127

Manheim Glass House, 125

Marcus Hook, 82, 96

MARIA FORGE, 135

Marke, Thomas, 20

Marriages among the iron masters, 159

Martic Forge and Furnace, 136

Mary Ann Furnace, 160, 171

Masters, Thomas, 12

Matthews, William, the Quaker surveyor, 160

Maxwell, General, 34

Maybury, Silvanus, 79

Maybury, Mayburry, Thomas, 66, 81, 133

Maybury, William, 176

McCall, Alexander, 40

McCall, Archibald, 40

McCall, George, 39, 40

McCall, Samuel, 40

McCalla, Capt. John, 148

MCCALL'S or Glasgow Forge, 39

McCalmont, John, 139

McClenachan, Blair, 87

McGrew, Archibald, 166

McGrew, Finley, 186

McKee, Capt. Thos., 138

McKonkly's Ferry, 54

McIlvaine, Ferguson, 138, 139

McQuatty, David, 32

Mennet, 129

Meredith, Rebecca, 103

Meyer, David, 169

Middle Forges, 79

Mifflin, Geo., 15, 22, 23, 64

Mifflin, Thomas (Governor), 58

Mifling, George, 64

Military service, exemption from, 188
Miller, Jacob, 161

Miller, John, 142

Miller, Michael, 115

Milltown (Abington), 12

Mine Ridge, 5

Mitchel, a Swiss miner, 4, 5

Moll, Henry, 178

Monocacy Road, 160

Montgomery County, forges in, 37, $39,57,66,143,180,188$

Montgomery, Wm., 140

Moorehead, Wm. G., 187

Moravian stove, 123

Morgan, General Daniel, 56

Morgan, Jacob, 114

Morgan, James, 50, 56, 57

Morgantown, 154

Morlatton, Malanton, 30, 76, 77

Morris, Anthony, 1, 15, 20, 22, 23, $39,45,58,60,64,172,173$

Morris, Benjamin, 157, 158

Morris, Cadwallader, 77, 157

Morris family, 61

Morris, Francis, 79

Morris, Henry, 116

Morris, John, 172

Morris, Margaret, 150

Morris, Maurice, 20

Morris, Morris, 64

Morris, Richard Hill, 151

Morris, Robert, purchase of Stiegel home by, 129

Morris, Mrs Robert, letter of, 128

Morris, Samuel, 172

Moselem Creek, 170

MOSELEM Forge, 170

Moselem mine, 170, 176

Mount JoY, or VALLEY Forge, 90, 145

Mount Joy Forge burned by the British, 93

Mount Joy Forge, submerging of, 95 
Mount Pleasant Furnace and FORGE, 75

Muhlenberg, Rev. William A., 132

Mules, transportation of iron by, 182

Munroe, George, 139

Musgrave, Joseph, 139, 140

Musgrove, Edward, 171

Musket barrels, boring of, during Revolution, 139

Muskets for Continental Army, 156, 157

Muskets from Warwick Furnace, 155

\section{N}

Navy, cannon and shot for, 169

Neil, Thomas, 177

Nepham, Stacy, 140

New Goshenhoppen, 135

New Market Forge, 87, 135

New Pine Forges, 79, 154

Nieman, Zachariah, 140

Nikoll, John George, 115

Nixon, John, 157

Noblitt, Abraham, 166

Norris, Isaac, 29, 61

North, Col. Caleb, 93

Nutt, Anna, 18, 28, 34, 69, 70

Nutt, Rebecca, 34

Nutt, Samuel, 16, 17, 19, 27, 33, 69, 74

Nutt, Samuel, Jr., 29, 34, 70, 93

Nutt's dealings with Indians, 13

Nutt Road, 29

\section{O}

Octorara Creek, 41

Offley, Caleb, 147, 148

Offley, Daniel, 147, 148, 149, 150, 151

Offley, Margaret, 147

OFFLEY'S ANCHOR FORGE, 147

Old, Anne, 87, 135, 159
Old, Caroline, 116

Old, James, $81,87,116,135,157$, 159

Old, John, 152, 153, 158

Old, Joseph, 159

Old, Williarn, 116, 159

Oley Churches, 111, 158

OLEY FORGE, 111, 170

Oley Furnace, 176

Ore, discovery of, reward for, 17

Ore, iron, washing of, 7

Orth, Adam, 135

Osenbrigs, Oxenbrigs, Ozenbriggs, 33

Owen, Evan, 20

Owen, Griffith, 45, 55

Owen, John, 96, 144

\section{$\mathbf{P}$}

Paine, R. T., 86

Paris, Franklin stove used in, 73

Parker's Ford, 73

Paschal, Stephen, 17, 147

Pastorius, bailiff of Germantown, 13

Pastorius, German colonists under, 143

Patchwork quilts, 183

Patterson, Samuel, 139

Patton and Bird, 80

Patton, Colonel John, 76, 78, 81, 152

Paul, Michael, 145

Paxton Road, 89

"Peel," use of, 91

Pemberton, Israel, 57

Pen, Sir William, 3

Penn, Governor John, 39, 57, 83, 84, 128,138

Penn, Richard, 83, 84

Penn, Thomas, 83, 84

Penn, William, 36, 39, 42, 143, 162

Penn, William, dealings of, with Indians, 13

Pennsbury, Indian treaty at, 45 
Pennsylvanian Fireplace, 73

Penrose, C. B., 186

Penrose, Samuel, 38

Pequea, 104, 136

Peter Dick's Bloomary Forge, 151, 171

Peters, Richard, 57, 166, 172

Petty, John, 31

Peugh, James, 26, 27

Philadelphia, approach of British to, $73,94,128,155$

Philadelphia, early iron masters in, $121,122,147$

Philadelphia, hauling of iron to, 92

Philadelphia, historic bell presented to, 94

Philadelphia, old highway to, 89, 154

Philadelphia, sale of iron in, 19

Philadelphia County, forges in, 11, $20,39,62,75,111,143$

Physick, Edmund, Keeper of the Great Seal, 128

Pig iron, 66, 79

Pig iron, conversion of, into blooms, 6

Pig iron, exportation of, 11, 46

Pig-iron, transportation of, 50

Pigeon Hills, 151

Pine Creek, 158

Pine Forge, 62, 63, 145

Pine Grove, 166, 187

Pine Grove Furnace, 175, 181

Plumsted, Clement, 45

Poco Creek, 135

Pontoon bridge at Valley Forge, 94

Pool Forge, 11, 60, 63, 64, 159

Pool Forge, Indian attack upon, 14

Pool Forge, original owners of, 15

Pope, John, 166

Pope, Thomas, 186

Popodick, Indian King, 24

Popodickon, 23

Porter, George B., 106

Potter, General, 34
Potts, Anna, 63

Potts, David, 24, 62, 63, 75

Potts, John, 17, 40, 62, 63, 65, 91, 92, 114, 144, 146

Potts, Joseph, Jr., 40

Potts, Rebecca, 158

Potts, Robert S., 138, 139

Potts, Samuel, 40, 65, 74

Potts, Thomas, 1, 15, 20, 21, 22, 23, $24,60,62,63,64$

Potts, Thomas, as host to Washington, 146

Potts, Thomas, Jr., 39, 75, 144

Potts, Thomas, Sr., 144

Potts, Thomas W., 94

Potts' Forge, 34

Pottsgrove, 39, 145. See also Pottstown.

PotTsgrove Forge, 143

Pottstown, 39, 75, 145

Powel, Samuel, 45, 55

Powell, Sarah, 97

Pratt, Abraham, 12

Preston, Samuel, 15, 22, 23

Prisoners of war, Hessian, 85, 118, 130

Prisoners quartered in churches, 85

Profits from iron making, 111

Proprietary and Governor's Council, members of, 166

Provincial troops, arms of, 173

Public Library, first in America, 71

Puddled iron, 7

Pyewell, Wm., 22, 23

\section{Q}

Quakers absent from Assembly, 97

Quakers as ironmasters, 11, 21

Quakers, non-partisan sentiments of, 95

Queen Anne, silver chalice presented by, 13

QuitTaPahilla Forge, 87, 135 
$\mathbf{R}$

Ranger, Chief, of Province of Pennsylvania, 165

Read, Charles, 45

Read, Henry, 145

Read, Prothonotary, 87

Reading, 170

Reading, march of British to, 155

Reading Furnace, 16, 17, 25, 34, 70, 100,159

Reading Furnace, second, 31

Reagan, George, 178

Redding Furnace. See Reading Furnace.

Redemptioners, 32, 55, 92

Red Lion, 50

Rees, Mary, 62

Reis, Michael, 115

Richards, Owen, 72

Ridge Road, 154

Rifle Men, Battalion of, 167

Rigby, John S., 172

Robert, Anne, 16

Roberts, E., 57

Robeson, Andrew, 144

Robeson, Magdelen, 144

Robesonia, 153

Rockland Forges, 176

Rodgers, Owen, 72

Rodgers, Phillip, 27

Rodman, Sarah, 149

Rolling Mills, 40, 96, 138

Rose, red, as annual rental, 124

Roses, Feast of, 120, 125

Ross, Catherine, 167, 168

Ross, George, the Signer, 56, 113, $161,162,169,171$

Ross, George, the Rector, of Newcastle, 78, 162

Ross, John, 111, 113, 162

Ross, Mary, 78

RoXborough, later Berkshire FURNACE, 76, 79, 80, 81, 152, 153
Royal proclamations, reading of, 71

Rum, restrictions concerning, 32

Rush, Anthony, 153

Rush, Colonel, 103

Rush, Sarah Aurelia, 103

Rutter, Anna, 28

Rutter, David, 40

Rutter, John, 20, 23

Rutter, Margaret, 63

Rutter, Rebecca, 18, 24, 75

Rutter, Thomas, 1, 12, 15, 18, 20,

$21,22,23,26,42,60,63,66,144$

Rutter, Thomas, Jr., 74, 75

S

SALFORd FORGE, 188

Sanatoga, 146

Sanderson, Francis, 172, 173

SARUM IRONWORKS, 96

Sassoonan, King of the Delawares, 14

Sauer, Christopher, 73

Savage, Anna, 28

Savage, Ruth, 29

Savage, Samuel, 26

Savage, Seeny, 62

Saw Hole, 130

Schoepf, Dr. John D., 50

Schultz, David, 133

Schuylkill Canal, 76

Schuylkill River, crossed by invading army, 93, 94

Schuylkill River, navigation of, 19

Schuylkill region, iron mines in, 143

Schwenkfelders' arrival from

Europe, 133

Scotch-Irish frontiersmen, 167

Scriptural texts on stoves, 8,9

Scull, Nicholas, surveyor, 24, 165

Scull's maps of Pennsylvania, 24, $39,48,154,166,180$

Seligman, Henry, 92

Shaw, Henry, 148 
Shaw, John, 81

Shawnee Indians, King of, 4, 5

Shell, casting of, $54,55,73,86,153$

Ship " Amity," 62

Ship Cyrus, 149

Ship Nancy, 120

Shippen, Edward, 57, 136

Shoemaker, Benjamin, 166

Shöffer, Jacob, 170

Shot, casting of, $54,55,86,118$, 153,169

Simon, Jacob, 186

SiR William Keith's Furnace, 36

Slitting mills, 96

Slough, Matthias, 141, 142

Smith, James, the Signer, 177

Smith, Rev. Robert, D.D., 104

Smith, Thomas, 136, 137, 138, 139

Smith, Dr. William, first Provost of

University of Pennsylvania, 73

Smith, William, 136, 161

Snyder, Henry, 72

Society of Free Traders, 13

South Mountain, 172, 181, 182, 187

Spain, origin of bloomary in, 6

Spang Forge, 114

Spang, Frederick, 114

SPEEDWELL FORGE, 87, 159

Sping, Andrew, 72

Spotswood, Governor, 98

Spring Book, 153

SPRING FORGE, I, 58

SPRING FORGE, II, 158

SPRING ForGE, III, 151, 169, 171, 175

Staples, Rebecca, 12

Stapleton, Robert, 111

State pension, 168

Stedman, Alexander, 121, 129

Stedman, C. and A., 115, 123, 124

Stedman, Charles, 81, 121, 129

Steel first made in America, 26

Steel furnace, pioneer, in Philadelphia, 17
Steel, James, 28

Stein, -, 115

Steinmetz, John, 169

Stengel family, 120

Stenton, firebacks at, 49, 61

Stevenson, Catherine, 166

Stevenson, George, 160, 161, 165, 166,186

Stevenson, George, as Chief Ranger of York Co., 165

Stevenson, Henry, 165

Stevenson, Mary and Nancy, 166

Stewart, Capt. Lazerus, 137

Stiegel, Barbara, 121

Stiegel, Elizabeth, 116, 159

Stiegel glassware, 126

Stiegel, Henry William, 1, 115, 119, 159

Stiegel, Jacob, 121

Stockley, John S., 147

Stove bearing patriotic motto, 154

Stove invented by Franklin, 70, 72

Stove, wall warming, 9

Stove plates, decoration of, 9, 121

Stove plates, decoration of, Biblical, 50

Stoves, casting of, 8, 133

Stowe, 62

Stratford, 62

Strettell, Robert, 166

Stroudwater blankets, 14

Stuart, Gilbert, portrait of Washington, 131

Sullivan, General, 94

Supreme Executive Council, 163, 164

Supreme Executive Council, Lesher's letter to, 112

Surrie, John, 79

Susquehanna River, boats used on, 51

Susquehanna River, shipment of coal, down, 173

Sutter, Peter, 140

Swede's Ford, 77, 93 
Swedes, settlements of, at Morlat$\tan , 30$

\section{$\mathrm{T}$}

Taylor, George, 55, 56

Taylor, Isaac, 27

Taylor, Jacob, Surveyor-General, 28

Taylor, John, 28, 96

Tariff law in 1789,75

Tariff, protective, votes for, 107

Tennessee mountaineers, 182, 185

Thomas, Governor, proclamation of, 70

Thompson, General William, 160, 161, 168

Thompson, General William, Colonel's commission to, 167

Thompson, Mary, 165

Thomson, Charles, Secretary of the Continental Congress, 61

Thornburg, Robert, 172, 186

Till, William, 166

Tower Hill, 124

Tulpehocken Eisenhammer, 115, 123

Turner, Joseph, 45, 84, 166

\section{$\mathrm{U}$}

Udree, General Daniel, 176

Union Canal, 89

Union Furnace, 178

Union Iron Works, 47

Union, transport, 168

United States, first Treasurer of, 142

\section{V}

VALLEY Forge, 29, 34, 56, 90, 145, 154. See also Mount Joy Forge.

Valley Forge, Continental Army at, 19, 146

Valley Forge, evacuation of, 94

Valley Forge, headquarters of Washington at, 94

Valley Forge, preaching at, 103
Van Gezel, Catherine, 162

Van Leer, Bernhard, 18

Vaux, James, 94

Vaux, James, Washington at house of, 95

Veneada, George, 81

Vincent Steel Works, 17, 18

Von Hiester, General, 130

W

Walker, Daniel, 91

Wallace, James, 137

Warwick, Washington at, 74

WARWICK FURNACE, 63, 69, 154, 155

Washington, General George, and Canadian Campaign; 167

Washington, Gen'l George, as guest of James Vaux, 95

Washington, General George, as guest of Robert Coleman, 131

Washington, General George, as guest of Thomas Potts, 19, 146

Washington, General George, at Valley Forge, 95, 103, 104

Washington, Gen'l George, letter of, to Gen. Wayne, 34

Washington, Gen'l George, letter of, to President of Congress, 74

Washington, Gen'l George, march of, to French Creek and Pottsgrove, 155

Washington's Headquarters, 29, 73

Washingtonburg, 173

Watson, John F., 148

Watson, Patrick, 166

Watts, Hon. Frederick, 186

Watts, William M., 186, 187

Wayne, General Anthony, 35, 92

Wayne, General, at Three Rivers, 168

Wayne, Isaac, 92

Webb, James, 137, 139

Webb, Samuel, 138 
Webb, William, 138

Weight, Benjamin, 25

Weiss, Weitzius, Rev. George Michael, 66, 135

Welcker, Dietrich, 176

Wells Falls, 51

Welsh, John, 140

Wernersville, 152

West, Edward, 64

West, Tommy, 64

Whiskey Insurrection, 88

White, Thomas (Mrs.), 128

Whiteford, Hugh, 166

Wilkes-Barre, 173

Wilkin, Matthew, 140

Wilkins, John, 166

Williams, Joseph, 91

Willow Grove turnpike, 37

Wilson, James, the Signer, 78

WINDSOR FORGES, 17, 98, 154

WindsoR FurNace, 178, 179

Winey, Jacob, 178

Winter, John and Walter, 31

Wishon, Conrad, 80

Wistar, Doctor, attendance of, on fever victims, 150

Wolff, Anna Dorothea, 175

Womelsdorf, 115, 124, 153
Women's work at furnaces, 181

Wood, consumption of, in furnaces,

$23,110,156,181$

Wood, Elizabeth, 121

Wooddrop, Alexander, 15, 22, 23, 64

Woodland, destruction of, 40

Woodman, Henry, 90

Y

Yarnall, Dr. Peter, 150

Yeates, Anne, 40

Yeates, Jasper, 130, 164

Yeldale, Anthony, 140

Yellow Springs, 74, 155

Yoder, John, 111

York, 169

York County, 97, 118, 151, 160, 171, 177

Yorke \& Potts, 80

Yorke, Thomas, 19, 64

Young, James, Paymaster, 173

Young, Peter, 140

\section{Z}

Zantzinger, Paul, 81, 117

Zerby, Hanes, 81 




SMITHSONIAN INSTITUTION LIBRARIES 